\title{
The Chemical Analysis of - Argonne Premium Coal Samples
}

\section{U.S. GEOLOGICAL SURVEY BULLETIN 2144}

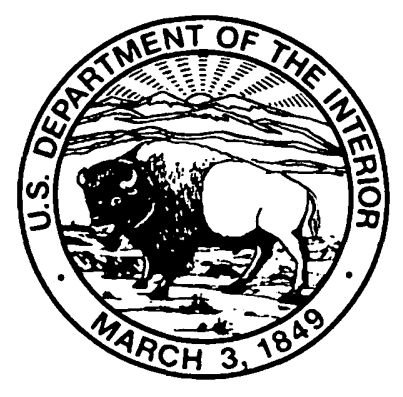

"ORTON MEASORIAL LIBRARY

THE OHIO STATE UNIVERAITY 155 S. OVAL DRIVE

FEB $2<2000$ 


\section{The Chemical Analysis of Argonne Premium Coal Samples}

Edited by Curtis A. Palmer

\section{U.S. GEOLOGICAL SURVEY BULLETIN 2144}

This manual presents analytical data from currently recommended procedures as well as procedures used in the 1980's by the geochemical laboratories of the U.S. Geological Survey for the chemical characterization of coal and a comparison of the results of these procedures for the Argonne Premium Coal samples. 


\title{
U.S. DEPARTMENT OF THE INTERIOR BRUCE BABBITT, Secretary
}

\section{U.S. GEOLOGICAL SURVEY GORDON P. EATON, Director}

\author{
For sale by U.S. Geological Survey, Information Services
}

Box 25286, Federal Center, Denver, CO 80225

\begin{abstract}
Any use of trade, product, or firm names in this publication is for descriptive purposes only and does not imply endorsement by the U.S. Government.
\end{abstract}

Published in the Eastern Region, Reston, Va. Manuscript approved for publication July 10, 1995.

\section{Library of Congress Cataloging in Publication Data}

The chemical analysis of Argonne Premium Coal samples / edited by Curtis A. Palmer.

p. $\quad \mathrm{cm}$. - (U.S. Geological Survey bulletin; 2144)

Includes bibliographical references.

Supt. of Docs. No.: I 19.3:B2144

1. Coal-United States-Analysis. I. Palmer, Curtis A. II. Series.

QE75.B9 no. 2144

[TP326.U6]

662.6'22973-dc20

96-36480

CIP 


\section{CONTENTS}

The Chemical Analysis of Argonne Premium Coal Samples: An Introduction

By Curtis A. Palmer

Rehydration of Desiccated Argonne Premium Coal Samples

By Marta R. Krasnow and Robert B. Finkelman .

Determination of 62 Elements in 8 Argonne Premium Coal Ash Samples by Automated Semiquantitative Direct-Current Arc Atomic Emission Spectrography

By Carol J. Skeen, B.J. Libby, and W.B. Crandell

Determination of 18 Elements in 5 Whole Argonne Premium Coal Samples by Quantitative Direct-Current Arc Atomic Emission Spectrography

By Janet D. Fletcher and Carol J. Skeen .

Determination of Major and Trace Elements in Eight Argonne Premium Coal

Samples (Ash and Whole Coal) by X-Ray Fluorescence Spectrometry

By John R. Evans, George A. Sellers, Robert G. Johnson, Davison V. Vivit, and Judy Kent

Determination of 29 Elements in 8 Argonne Premium Coal Samples by Instrumental Neutron Activation Analysis

By Curtis A. Palmer

Determination of Selected Elements in Coal Ash from Eight Argonne Premium

Coal Samples by Atomic Absorption Spectrometry and Atomic Emission

Spectrometry

By Michael W. Doughten

Determination of 25 Elements in Coal Ash from 8 Argonne Premium Coal

Samples by Inductively Coupled Argon Plasma-Atomic Emission Spectrometry

By Paul H. Briggs.

Determination of 33 Elements in Coal Ash from 8 Argonne Premium Coal

Samples by Inductively Coupled Argon Plasma-Mass Spectrometry

By Allen L. Meier

Determination of Mercury and Selenium in Eight Argonne Premium Coal

Samples by Cold-Vapor and Hydride-Generation Atomic Absorption

Spectrometry

By Richard M. O'Leary.

Determination of Carbon, Hydrogen, and Nitrogen in Eight Argonne Premium

Coal Samples by Using a Gas Chromatographic Analyzer with a Thermal

Conductivity Detector

By Carol J. Skeen and Zoe A. Brown

Compilation of Multitechnique Determinations of 51 Elements in 8 Argonne

Premium Coal Samples

By Curtis A. Palmer and Sarah A. Klizas 
Appendix 1. Comparison of the Concentrations of 51 Elements Determined by

Multiple Analytical Techniques in 8 Argonne Premium Coal Samples 77

Appendix 2. Statistical Parameters for the Data in Appendix 1

\section{CONVERSION FACTORS}

Both metric and inch-pound units are used by the different authors. Conversion factors are given below.

\begin{tabular}{|c|c|c|}
\hline Multiply & By & To obtain \\
\hline \multicolumn{3}{|c|}{ Length } \\
\hline nanometer (nm) & $0.03937 \times 10^{-6}$ & inch \\
\hline micrometer $(\mu \mathrm{m})$ & $0.03937 \times 10^{-3}$ & inch \\
\hline millimeter (mm) & 0.03937 & inch \\
\hline meter $(m)$ & 3.281 & foot \\
\hline inch & 25.4 & millimeter \\
\hline \multicolumn{3}{|c|}{ Mass } \\
\hline picogram (pg) & $1.543 \times 10^{-11}$ & grain \\
\hline nanogram (ng) & $1.543 \times 10^{-8}$ & grain \\
\hline microgram $(\mu \mathrm{g})$ & $1.543 \times 10^{-5}$ & grain \\
\hline milligram (mg) & $1.543 \times 10^{-2}$ & grain \\
\hline gram $(\mathrm{g})$ & 0.03527 & ounce avoirdupois \\
\hline \multicolumn{3}{|c|}{ Volume } \\
\hline microliter $(\mu \mathrm{L})$ & 0.016 & minims \\
\hline milliliter $(\mathrm{mL})$ & 0.0338 & fluid ounce \\
\hline cubic centimeter $\left(\mathrm{cm}^{3}\right)$ & 0.06102 & cubic inch \\
\hline \multicolumn{3}{|c|}{ Flow } \\
\hline liter per minute $(\mathrm{L} / \mathrm{min})$ & 0.2642 & gallon/minute \\
\hline \multicolumn{3}{|c|}{ Force per unit area } \\
\hline pound per square inch (lb/in²) & 6,895 & pascal \\
\hline
\end{tabular}

For temperature conversions from degrees Celsius $\left({ }^{\circ} \mathrm{C}\right)$ to degrees Fahrenheit $\left({ }^{\circ} \mathrm{F}\right)$, use the following:

$$
\left(1.8 \times{ }^{\circ} \mathrm{C}\right)+32={ }^{\circ} \mathrm{F}
$$

Standard reference materials. - The National Bureau of Standards (NBS) was renamed the National Institute of Standards and Technology (NIST) in 1988. In this report, standard reference materials from this agency are called NIST 1632a and so on, and the certificates of analysis of the reference materials are cited as National Bureau of Standards publications. 


\title{
THE CHEMICAL ANALYSIS OF ARGONNE PREMIUM COAL SAMPLES
}

\author{
Edited by Curtis A. Palmer
}

\section{The Chemical Analysis of Argonne Premium Coal Samples: An Introduction}

\author{
By Curtis A. Palmer
}

\begin{abstract}
Methods used to determine the concentrations of 67 elements in 8 Argonne Premium Coal samples are summarized in this bulletin. Seventeen different pro-cedures involving 11 different techniques were used. Sample identification, sample protocol, and sample descriptions are presented.
\end{abstract}

\section{INTRODUCTION}

This bulletin contains papers discussing the U.S. Geological Survey's chemical analyses of eight Argonne Premium Coal samples. The papers present analytical results obtained from all the methods used in the analyses and give a comparison of the results for elements where more than one technique was used. This paper describes the samples, explains the numbering protocol used throughout this bulletin, and lists the elements whose concentrations were determined by each technique used.

A detailed description of the samples, the reasons for their collection, and other background information have been reported by Vorres $(1990,1993)$. Table 1 contains the sample identification for the eight Argonne Premium Coal samples used in this study, with the seam, location, rank, and ash yield for each. The samples come from seven different States and range in rank from lignite to low volatile bituminous. The sample identification protocol is similar to that used by Vorres (1990). It consists of a two- to four-letter identifier that represents either the State or the seam from which the sample was obtained, followed by one or more spaces, the letters "PC" for Premium Coal, and a dash fol- lowed by sample numbers 1 through 8 . In the papers that follow, splits are identified by the addition of a dash and another number after the sample number. For example, split 2 of Premium Coal sample 1 is identified as UF PC-1-2, with UF designating the Upper Freeport coal seam from which Premium Coal sample 1 was obtained.

Seventeen different procedures involving 11 different techniques were used to determine concentrations of 67 different elements. Ten of these procedures required coal ash, and the other seven used the whole coal. Table 2 shows the

Table 1. Sample identification, location, rank, and ash yield of the eight Argonne Premium Coal samples analyzed in this work.

[Ash yields are taken from table 1 of Doughten's paper, this volume]

\begin{tabular}{|c|c|c|c|}
\hline Sample ID & State & Rank & $\begin{array}{c}\text { Ash } \\
\text { yield } \\
(\%)\end{array}$ \\
\hline $\begin{array}{c}\text { UF PC-1 .............. Upper } \\
\text { Freeport. }\end{array}$ & $\mathrm{Pa}$. & $\begin{array}{l}\text { Medium } \\
\text { volatile } \\
\text { bituminous. }\end{array}$ & 13.5 \\
\hline $\begin{array}{l}\text { WY PC-2 ............ Wyodak- } \\
\text { Anderson. }\end{array}$ & Wyo. & Subbituminous & 8.5 \\
\hline IL PC-3 ............... Illinois No. 6 & Ill. & $\begin{array}{l}\text { High volatile } \\
\text { bituminous. }\end{array}$ & 16.2 \\
\hline $\begin{array}{r}\text { PITT PC-4 .......... Pittsburgh } \\
\text { (No. 8). }\end{array}$ & $\mathrm{Pa}$. & $\begin{array}{l}\text { High volatile } \\
\text { bituminous. }\end{array}$ & 9.2 \\
\hline $\begin{array}{c}\text { POC PC-5 .......... Pocahontas } \\
\text { No. } 3 .\end{array}$ & Va. & $\begin{array}{l}\text { Low volatile } \\
\text { bituminous. }\end{array}$ & 5.3 \\
\hline $\begin{array}{c}\text { UT PC-6 ............. Blind } \\
\text { Canyon. }\end{array}$ & Utah & $\begin{array}{l}\text { High volatile } \\
\text { bituminous. }\end{array}$ & 4.6 \\
\hline $\begin{array}{c}\text { WV PC-7 ............ Lewiston- } \\
\text { Stockton. }\end{array}$ & W. Va. & $\begin{array}{l}\text { High volatile } \\
\text { bituminous. }\end{array}$ & 19.4 \\
\hline ND PC-8 ............. Beulah-Zap & N. Dak. & Lignite & 9.5 \\
\hline
\end{tabular}


Table 2. Tabulation of elements determined by different techniques.

[DCAES, direct-current arc atomic emission spectrography; XRF, X-ray fluorescence spectrometry; INAA, instrumental neutron activation analysis; ICAPAES, inductively coupled argon plasma-atomic emission spectrometry, (R), Reston, (D), Denver; ICAP-MS, inductively coupled argon plasma-mass spectrometry; AAS, atomic absorption spectrometry; CVAAS, cold-vapor AAS; HGAAS, hydride-generation AAS; CHN, carbon-hydrogen-nitrogen elemental analysis; WC, whole coal]

\begin{tabular}{|c|c|c|c|c|c|c|c|c|c|c|c|c|c|}
\hline \multirow{3}{*}{ Element } & \multicolumn{12}{|c|}{ Technique and material } & \multirow{3}{*}{$\begin{array}{c}\text { Total } \\
\text { number } \\
\text { of } \\
\text { procedure }\end{array}$} \\
\hline & \multicolumn{2}{|c|}{ DCAES } & \multicolumn{2}{|c|}{ XRF } & \multirow{2}{*}{$\begin{array}{c}\text { INAA } \\
\text { WC }\end{array}$} & \multirow{2}{*}{$\begin{array}{c}\text { ICAP- } \\
\text { AES(R) } \\
\text { Ash }\end{array}$} & \multirow{2}{*}{$\begin{array}{l}\text { ICAP. } \\
\text { AES(D) } \\
\text { Ash }\end{array}$} & \multirow{2}{*}{$\begin{array}{l}\text { ICAP-MS } \\
\text { Ash }\end{array}$} & \multirow{2}{*}{$\begin{array}{c}\text { AAS } \\
\text { Ash }\end{array}$} & \multirow{2}{*}{$\begin{array}{c}\text { CVAAS } \\
\text { WC }\end{array}$} & \multirow{2}{*}{$\begin{array}{c}\text { HGAAS } \\
\text { WC }\end{array}$} & \multirow{2}{*}{$\begin{array}{c}\text { CHN } \\
\text { WC }\end{array}$} & \\
\hline & wC & Ash & WC & Ash & & & & & & & & & \\
\hline 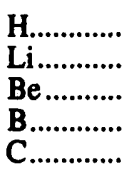 & & $\underset{\mathbf{X}}{\mathbf{X}}$ & & & & $\mathbf{X}$ & $\begin{array}{l}X \\
X \\
X^{2}\end{array}$ & & $\mathrm{X}$ & & & $\mathrm{x}$ & $\begin{array}{l}1 \mathrm{H} \\
2 \mathrm{Li} \\
3 \mathrm{Be} \\
2 \mathrm{~B} \\
1 \mathrm{C}\end{array}$ \\
\hline 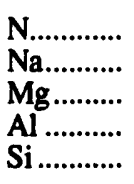 & $\begin{array}{l}\mathbf{X} \\
\mathbf{X} \\
\mathbf{X}\end{array}$ & $\begin{array}{l}\mathbf{X} \\
\mathbf{X} \\
\mathbf{X} \\
\mathbf{X}\end{array}$ & & $\begin{array}{l}\mathbf{X}^{1} \\
\mathbf{X}^{1} \\
\mathbf{X}^{1} \\
\mathbf{X}^{1}\end{array}$ & $\mathbf{X}$ & $\begin{array}{l}\mathbf{X} \\
\mathbf{X} \\
\mathbf{X}\end{array}$ & $\begin{array}{l}X \\
X^{2} \\
X^{2} \\
X^{2}\end{array}$ & & & & & $\mathrm{X}$ & $\begin{array}{l}1 \mathrm{~N} \\
5 \mathrm{Na} \\
5 \mathrm{Mg} \\
5 \mathrm{Al} \\
4 \mathrm{Si}\end{array}$ \\
\hline 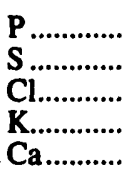 & $\mathbf{X}$ & $\begin{array}{l}\mathbf{X} \\
\mathbf{X}\end{array}$ & $\begin{array}{l}\mathbf{X}^{\mathbf{1}} \\
\mathbf{X}^{\mathbf{1}}\end{array}$ & $\begin{array}{l}\mathbf{X}^{1} \\
\mathbf{X}^{1} \\
\mathbf{X}^{1} \\
\mathbf{X}^{1}\end{array}$ & $\mathbf{X}$ & $\begin{array}{l}\mathbf{X} \\
\mathbf{X}\end{array}$ & $\begin{array}{l}X^{2} \\
X^{2} \\
X^{2}\end{array}$ & & & & & & $\begin{array}{l}5 \mathrm{P} \\
1 \mathrm{~S} \\
1 \mathrm{Cl} \\
5 \mathrm{~K} \\
5 \mathrm{Ca}\end{array}$ \\
\hline 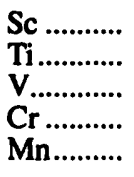 & $\begin{array}{l}\mathbf{X} \\
\mathbf{X} \\
\mathbf{X} \\
\mathbf{X}\end{array}$ & $\begin{array}{l}\mathbf{X} \\
\mathbf{X} \\
\mathbf{X} \\
\mathbf{X} \\
\mathbf{X}\end{array}$ & $\mathbf{X}$ & $\begin{array}{l}\mathbf{X}^{1} \\
\mathbf{X} \\
\mathbf{X}^{1}\end{array}$ & $\mathrm{X}$ & $\begin{array}{l}\mathbf{X} \\
\mathbf{X} \\
\mathbf{X} \\
\mathbf{X}\end{array}$ & $\begin{array}{l}X \\
X^{2} \\
X \\
X \\
X\end{array}$ & & & & & & $\begin{array}{l}3 \mathrm{Sc} \\
5 \mathrm{Ti} \\
4 \mathrm{~V} \\
7 \mathrm{Cr} \\
5 \mathrm{Mn}\end{array}$ \\
\hline $\begin{array}{l}\mathrm{Fe} \ldots \ldots . . . . \\
\mathrm{Co} . . . . . . . . \\
\mathrm{Ni} \ldots . . . . . . . \\
\mathrm{Cu} . . . . . . . . \\
\mathrm{Zn} \ldots . . . . . . .\end{array}$ & $\begin{array}{l}\mathbf{X} \\
\mathbf{X} \\
\mathbf{X} \\
\mathbf{X} \\
\mathbf{X}\end{array}$ & $\begin{array}{l}\mathbf{X} \\
\mathbf{X} \\
\mathbf{X} \\
\mathbf{X}\end{array}$ & $\begin{array}{l}\mathbf{X} \\
\mathbf{X} \\
\mathbf{X}\end{array}$ & $\begin{array}{l}\mathbf{X}^{\mathbf{1}} \\
\mathbf{X} \\
\mathbf{X} \\
\mathbf{X}\end{array}$ & $\begin{array}{l}\mathbf{X} \\
\mathbf{X} \\
\mathbf{X} \\
\mathbf{X}\end{array}$ & $\begin{array}{l}X \\
X \\
X \\
X\end{array}$ & $\begin{array}{l}\mathrm{X}^{2} \\
\mathrm{X} \\
\mathrm{X} \\
\mathrm{X} \\
\mathrm{X}\end{array}$ & & $\mathrm{X}$ & & & & $\begin{array}{l}6 \mathrm{Fe} \\
5 \mathrm{Co} \\
7 \mathrm{Ni} \\
6 \mathrm{Cu} \\
6 \mathrm{Zn}\end{array}$ \\
\hline $\begin{array}{l}\text { Ga.......... } \\
\text { Ge.......... } \\
\text { As.......... } \\
\text { Se ........... } \\
\text { Br ........... }\end{array}$ & $\underset{\mathbf{X}}{\mathbf{X}}$ & $\begin{array}{l}\mathbf{X} \\
\mathbf{X} \\
\mathbf{X}\end{array}$ & & & $\begin{array}{l}\mathbf{X} \\
\mathbf{X} \\
\mathbf{X}\end{array}$ & & & $\begin{array}{l}\mathbf{X} \\
\mathbf{X} \\
\mathbf{X}\end{array}$ & & & $\mathbf{X}$ & & $\begin{array}{l}3 \mathrm{Ga} \\
3 \mathrm{Ge} \\
3 \mathrm{As} \\
2 \mathrm{Se} \\
1 \mathrm{Br}\end{array}$ \\
\hline 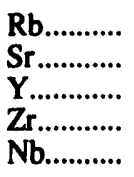 & $\mathbf{X}$ & $\begin{array}{l}\mathbf{X} \\
\mathbf{X} \\
\mathbf{X} \\
\mathbf{X}\end{array}$ & $\begin{array}{l}\mathbf{X} \\
\mathbf{X} \\
\mathbf{X} \\
\mathbf{X} \\
\mathbf{X}\end{array}$ & $\begin{array}{l}\mathbf{X} \\
\mathbf{X} \\
\mathbf{X} \\
\mathbf{X} \\
\mathbf{X}\end{array}$ & $\begin{array}{l}X \\
X\end{array}$ & $\begin{array}{l}\mathbf{X} \\
\mathbf{X}\end{array}$ & $\begin{array}{l}X \\
X \\
X^{2}\end{array}$ & $X$ & & & & & $\begin{array}{l}4 \mathrm{Rb} \\
6 \mathrm{Sr} \\
5 \mathrm{Y} \\
5 \mathrm{Zr} \\
4 \mathrm{Nb}\end{array}$ \\
\hline $\begin{array}{l}\text { Mo.......... } \\
\text { Ag........... } \\
\text { Cd........... } \\
\text { Sn ........... } \\
\text { Sb .......... }\end{array}$ & & $\begin{array}{l}\mathbf{X} \\
\mathbf{X} \\
\dot{X}\end{array}$ & & & $\mathbf{X}$ & & & $\begin{array}{l}X \\
X \\
X \\
X \\
X \\
X\end{array}$ & $\mathrm{X}^{4}$ & & & & $\begin{array}{l}2 \mathrm{Mo} \\
2 \mathrm{Ag} \\
2 \mathrm{Cd} \\
2 \mathrm{Sn} \\
2 \mathrm{Sb}\end{array}$ \\
\hline $\begin{array}{l}\text { Te............ } \\
\text { Cs.......... } \\
\text { Ba_......... } \\
\text { La _.......... } \\
\text { Ce.......... }\end{array}$ & $\mathrm{x}$ & $\begin{array}{l}\mathbf{X} \\
\mathbf{X} \\
\mathbf{X}\end{array}$ & $\begin{array}{l}\mathbf{X} \\
\mathbf{X} \\
\mathbf{X}\end{array}$ & $\begin{array}{l}\mathbf{X} \\
\mathbf{X} \\
\mathbf{X}\end{array}$ & $\begin{array}{l}X \\
X \\
X \\
X\end{array}$ & $\mathrm{X}$ & $\mathrm{X}^{2}$ & $\begin{array}{l}X \\
X \\
X^{3} \\
X^{3}\end{array}$ & & & & & $\begin{array}{l}1 \mathrm{Te} \\
2 \mathrm{Cs} \\
7 \mathrm{Ba} \\
5 \mathrm{La} \\
5 \mathrm{Ce}\end{array}$ \\
\hline 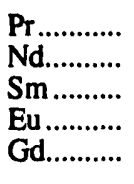 & & $\begin{array}{l}\mathbf{X} \\
\mathbf{X} \\
\mathbf{X} \\
\mathbf{X}\end{array}$ & & & $\begin{array}{l}\mathbf{X} \\
\mathbf{X} \\
\mathbf{X}\end{array}$ & & . & $\begin{array}{l}X^{3} \\
X^{3} \\
X^{3} \\
X^{3} \\
X^{3}\end{array}$ & & & & & $\begin{array}{l}2 \mathrm{Pr} \\
3 \mathrm{Nd} \\
3 \mathrm{Sm} \\
3 \mathrm{Eu} \\
1 \mathrm{Gd}\end{array}$ \\
\hline $\begin{array}{l}\text { Tb........... } \\
\text { Dy........... } \\
\text { Ho.......... } \\
\text { Er........... } \\
\text { Tm.......... }\end{array}$ & & & & & $\mathrm{X}$ & & & $\begin{array}{l}X^{3} \\
X^{3} \\
X^{3} \\
X^{3} \\
X^{3}\end{array}$ & & & & & $\begin{array}{l}2 \mathrm{~Tb} \\
1 \mathrm{Dy} \\
1 \mathrm{Ho} \\
1 \mathrm{Er} \\
1 \mathrm{Tm}\end{array}$ \\
\hline
\end{tabular}


Table 2. Tabulation of elements determined by different techniques-Continued.

\begin{tabular}{|c|c|c|c|c|c|c|c|c|c|c|c|c|c|}
\hline \multirow{3}{*}{ Element } & \multicolumn{12}{|c|}{ Technique and material } & \multirow{3}{*}{$\begin{array}{c}\text { Total } \\
\text { number } \\
\text { of } \\
\text { procedures }\end{array}$} \\
\hline & \multicolumn{2}{|c|}{ DCAES } & \multicolumn{2}{|c|}{$\mathrm{XRF}$} & \multirow{2}{*}{$\begin{array}{l}\text { INAA } \\
\text { WC }\end{array}$} & \multirow{2}{*}{$\begin{array}{c}\text { ICAP- } \\
\text { AES(R) } \\
\text { Ash }\end{array}$} & \multirow{2}{*}{$\begin{array}{c}\text { ICAP- } \\
\text { AES(D) } \\
\text { Ash }\end{array}$} & \multirow{2}{*}{$\begin{array}{l}\text { ICAP-MS } \\
\text { Ash }\end{array}$} & \multirow{2}{*}{$\begin{array}{c}\text { AAS } \\
\text { Ash }\end{array}$} & \multirow{2}{*}{$\begin{array}{l}\text { CVAAS } \\
\text { WC }\end{array}$} & \multirow{2}{*}{$\begin{array}{l}\text { HGAAS } \\
\text { WC }\end{array}$} & \multirow{2}{*}{$\begin{array}{l}\text { CHN } \\
\text { WC }\end{array}$} & \\
\hline & WC & Ash & WC & Ash & & & & & & & & & \\
\hline $\begin{array}{l}\text { Yb .......... } \\
\text { Lu........... } \\
\text { Hf ........... } \\
\text { Ta ............ } \\
\text { W ........... }\end{array}$ & & $\mathbf{X}$ & & & $\begin{array}{l}\mathbf{X} \\
\mathbf{X} \\
\mathbf{X} \\
\mathbf{X} \\
\mathbf{X}\end{array}$ & & & $\begin{array}{l}X^{3} \\
X^{3} \\
X^{3} \\
X^{3}\end{array}$ & & & & & $\begin{array}{l}3 \mathrm{Yb} \\
1 \mathrm{Lu} \\
2 \mathrm{Hf} \\
2 \mathrm{Ta} \\
2 \mathrm{~W}\end{array}$ \\
\hline 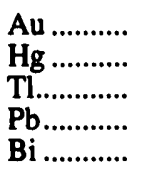 & $\mathbf{X}$ & $\begin{array}{l}\mathbf{X} \\
\mathbf{X}\end{array}$ & & & & & & $\begin{array}{l}\mathbf{X} \\
\mathbf{X} \\
\mathbf{X} \\
\mathbf{X}\end{array}$ & $\mathrm{X}^{4}$ & $\mathbf{X}$ & & & $\begin{array}{l}1 \mathrm{Au} \\
1 \mathrm{Hg} \\
1 \mathrm{Tl} \\
4 \mathrm{~Pb} \\
2 \mathrm{Bi}\end{array}$ \\
\hline $\begin{array}{l}\text { Th............ } \\
\text { U .................. }\end{array}$ & & & & & $\begin{array}{l}\mathbf{X} \\
\mathbf{X}\end{array}$ & & $\mathbf{X}$ & $\mathbf{X}$ & & & & & $\begin{array}{l}2 \mathrm{Th} \\
2 \mathrm{U}\end{array}$ \\
\hline TOTALS & 18 & 38 & 14 & 23 & 29 & 18 & 25 & 33 & 4 & 1 & 1 & 3 & 207 \\
\hline
\end{tabular}

'Wavelength-dispersive procedure; all other XRF procedures are energy-dispersive XRF.

${ }^{2}$ Sinter digestion procedure; all other ICAP-AES procedures are acid digestion procedures.

${ }^{3}$ Sinter digestion procedure; all other ICAP-MS procedures are acid digestion procedures.

${ }^{4}$ Graphite furnace AAS; all other AAS procedures are flame AAS.

elements, listed by atomic number, whose concentrations were determined by each procedure. Procedures include two direct-current arc atomic emission spectrography (DCAES) procedures, one on the ash and one on the whole coal; four X-ray fluorescence spectrometry (XRF) procedures, including both wavelength- and energy-dispersive procedures for the analysis of both the whole coal and the ash; and four atomic absorption spectrometry (AAS) procedures, including flame and graphite furnace AAS on the ash, cold-vapor atomic absorption spectrometry (CVAAS) procedures for mercury on the whole coal, and a hydridegeneration AAS (HGAAS) procedure for selenium. Other techniques include instrumental neutron activation analysis (INAA) and combustion/gas chromatographic analyses for carbon, hydrogen, and nitrogen (CHN), which were determined on the whole coal only. Five inductively coupled argon plasma procedures were made on the ash only. Three of these procedures used an acid digest: the two inductively coupled argon plasma-atomic emission spectrometry (ICAP-AES) procedures (one in Reston and one in Denver) and the inductively coupled argon plasma-mass spectrometry (ICAP-MS) on the acid digest prepared in Denver. Two additional procedures used a sinter digest: the ICAP-AES and the ICAP-MS procedures in Denver. Ash yield (see paper by Doughten, this volume) and moisture content (see paper by Krasnow and Finkelman, this volume) are also reported. A detailed description of each of these procedures is given in the following papers.

In addition to the concentrations of 38 elements determined by DCAES on the ash, lower limits of detection were reported for another 24 elements, making a total of 62 elements reported by DCAES in the paper by Skeen, Libby, and Crandell. Of the 67 different elements with reported concentrations, 51 were determined by more than one technique. Results obtained by different techniques are compared by Palmer and Klizas in this volume.

This bulletin is a greatly expanded version of a preliminary report edited by Palmer and Walthall (1991) that contained information on 58 elements, 33 of which had been determined by more than one technique. All of the preliminary data were collected at the analytical facilities of the U.S. Geological Survey (USGS) in Reston, Va., and represented the procedures used to analyze coal through 1990. In 1990, work was begun to develop a procedure to determine trace-element concentrations by only high-precision techniques. The determination of several of the elements by DCAES was replaced by ICAP-MS, a technique available within the USGS only in laboratories in Denver, Colo. Because the dissolution procedures for ICAP-MS and ICAP-AES are the same, all routine ICAP-AES determinations on coal were moved to the Denver facilities. These two techniques were appropriate for most of the elements previously determined by the Reston high-precision techniques: INAA, XRF, and AAS. Those techniques, therefore, have been dropped for routine analysis, although INAA is stịl used for many samples when determinations on the whole coal are necessary or when sample size is critical. One element determined by INAA and not determined with the new procedures was selenium. A hydride-generation AAS method was developed in Denver to determine selenium. A 
new procedure to determine mercury by CVAAS was also added. CHN information is routinely obtained by ultimate and proximate analysis of coal by an outside laboratory, although CHN is still determined in USGS laboratories on some research samples.

The following chapters include papers modified from the open-file report by Palmer and Walthall (1991), as well as new papers describing the new Denver techniques. Results in each paper are reported in the manner in which results are normally reported by the laboratory performing the analysis. In all the papers except the last, results from methods used to analyze ash are reported on an ash basis, whereas results from methods used to analyze whole coal are reported on a whole-coal basis. Similarly, concentrations of major rock-forming elements are reported on an oxide basis or an element basis depending on the standard practice of the laboratory performing the analysis. The units parts per million (ppm) and micrograms per gram $(\mu \mathrm{g} / \mathrm{g})$ are equivalent as are weight percent and percent (\%); all results in this report are on a weight basis.

The comparison chapter by Palmer (1991) in the openfile report has been completely rewritten by Palmer and Klizas as the last paper in this report to include all the new techniques and a statistical analysis of results for all 51 elements that were determined by more than one procedure. All results in the last paper are converted to an element basis and a whole-coal basis and are expressed in weight percent and parts per million. Although only eight samples are included in this bulletin, comparison of the data for old and new techniques is useful in determining the accuracy of the data in the National Coal Resource Data System (NCRDS), which contains data for over 13,000 coal and rock samples, 7,400 of which are available on CD-ROM (Bragg and others, 1994).

\section{REFERENCES}

Bragg, L.J., Oman, J.K., Tewalt, S.J., Oman, C.L., Rega, N.H., Washington, P.M., and Finkelman, R.B., 1994, U.S. Geological Survey coal quality (COALQUAL) data baseVersion 1.3: U.S. Geological Survey Open-File Report 94 205 (CD-ROM).

Palmer, C.A., 1991, Compilation of multi-element analysis of eight Argonne Premium Coal samples for 33 elements, in Palmer, C.A., and Walthall, F.G., eds., The chemical analysis of Argonne Premium Coal samples: U.S. Geological Survey Open-File Report 91-638, chap. I, p. 84-112.

Palmer, C.A., and Walthall, F.G., eds., 1991, The chemical analysis of Argonne Premium Coal samples. U.S. Geological Survey Open-File Report 91-638, 112 p.

Vorres, K.S., 1990, The Argonne Premium Coal Sample Program: Energy and Fuels, v. 4, no. 5, p. $420-426$.

1993, Users handbook for the Argonne Premium Coal Sample Program: Argonne National Laboratories Report ANL/PCSP-93/1, 200 p. 


\title{
Rehydration of Desiccated Argonne Premium Coal Samples
}

\author{
By Marta R. Krasnow and Robert B. Finkelman
}

\begin{abstract}
Eight Argonne Premium Coal samples stored in polyethylene bottles for several years exhibited substantial moisture losses. The samples retained an average of 23 percent of their original moisture content, with a range of 5 to 59 percent retention. Resaturated samples averaged 53 percent of the original moisture, with a range of 14 to 95 percent. If desiccated coal samples are to be analyzed, we recommend that moisture contents be determined prior to analysis. Drying coal samples prior to analysis would be an acceptable alternative if the original moisture content is known and the sample does not pick up moisture between drying and weighing for analysis.
\end{abstract}

\section{INTRODUCTION}

The Argonne National Laboratory has sealed its eight Premium Coal samples in glass ampoules filled with an inert gas (argon) to ensure that they retain their original properties during storage (Vorres, 1990). Once the ampoules are opened in a laboratory, however, sample alteration, such as dehydration and oxidation, can occur.

\section{EXPERIMENTAL}

We experienced a situation in which Argonne Premium Coal samples were stored in our laboratory for 2 to 4 years in polyethylene bottles, which allowed the samples to dehydrate (see columns 1 and 2 of table 1). A substantial amount of moisture had been lost from each sample during storage. This paper is intended to illustrate the degree of dehydration and to discuss the possibility of rehydrating the samples.

From 41 to 95 percent of the original moisture was lost during the unregulated storage of the "aged" samples. Sample WY PC-2 lost almost 20 weight percent moisture, and ND PC-8 lost more than 30 weight percent. Sample POC PC-5 lost the least absolute amount of moisture, slightly more than 0.5 weight percent.

To resaturate the samples, weighed splits of -100 mesh coal were placed in uncovered petri dishes in a vacuum des-
Table 1. Moisture of Argonne Premium Coal samples under different conditions.

[Values are in weight percent; all moisture values were determined by using the ASTM recommended procedure (ASTM, 1996a); Bit., bituminous; Sub., subbituminous; Lig., lignite]

\begin{tabular}{|c|c|c|c|}
\hline Sample identification & (1) & (2) & (3) \\
\hline Sample & $\begin{array}{l}\text { "Fresh" } \\
\text { samples' }\end{array}$ & $\begin{array}{c}\text { "Aged" } \\
\text { samples }^{2}\end{array}$ & $\begin{array}{c}\text { After } \\
\text { resaturation }\end{array}$ \\
\hline 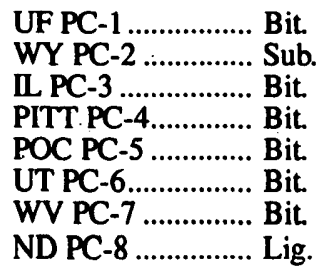 & $\begin{array}{r}1.13 \\
28.09 \\
7.97 \\
1.65 \\
.65 \\
4.63 \\
2.42 \\
32.24\end{array}$ & $\begin{array}{r}0.17(15) \\
8.79(31) \\
1.41(18) \\
.97(59) \\
.10(15) \\
.21(05) \\
.85(35) \\
1.94(06)\end{array}$ & $\begin{array}{r}0.16(14) \\
9.76(35) \\
6.77(85) \\
1.57(95) \\
.23(35) \\
3.29(71) \\
1.29(53) \\
11.90(37)\end{array}$ \\
\hline
\end{tabular}

\footnotetext{
'Samples in ampoules; data from Vorres (1993).

${ }^{2}$ Number. in parentheses is the percentage of original moisture content.
}

iccator containing a barometer and a thermometer. Approximately $800 \mathrm{~mL}$ of deionized water was added to the base of the desiccator. The samples were kept under atmospheric pressure in the desiccator at 90 percent relative humidity and $22^{\circ} \mathrm{C}$ for 24 hours, after which they were removed from the desiccator and weighed. Several samples had increases far in excess of the original moisture loss. For example, sample UF PC-1, which had lost about 1 weight percent moisture, increased over 5 weight percent. This "excess" moisture may be due to condensation on the coal particles. We therefore allowed the resaturated samples to equilibrate with the ambient atmosphere for 24 hours $\left(22^{\circ} \mathrm{C}-23^{\circ} \mathrm{C}, 60\right.$ 64 percent relative humidity) prior to determining the moisture (referred to as resaturated moisture) by the American Society for Testing and Materials (ASTM) (1996a) procedure (table 1, column 3).

After the 24-hour residency in the desiccator at the 90 percent relative humidity and subsequent equilibration, moisture increased substantially in most samples. Sample IL PC-3 regained 67 percent of the original moisture (table 1, column 1), and UT PC-6 regained 66 percent. Sample IL PC-3 regained 5.36 weight percent moisture, and ND PC-8 gained almost 10 weight percent. Only sample UF PC-1 
showed no gain in moisture. Despite the substantial increases in moisture for most samples, none of the samples, with the possible exception of PITT PC-4, recovered all the moisture lost on drying.

Experiments on water desorption and adsorption have been conducted by varying vapor pressure and holding the temperature constant, usually less than $40^{\circ} \mathrm{C}$ (Gauger, 1945; Allardice and Evans, 1978). Results of the experiments indicate that, once dry, a coal sample will not adsorb enough water to regain its original moisture content. There is no generally accepted mechanism to explain this phenomenon (Allardice and Evans, 1978); however, several theories have been offered. These include (1) the shrinking of coal on drying, which causes a collapse of some capillaries, so that the dried material can no longer hold or take up as much water as it held originally, and (2) the replacement of moisture on the walls of some capillaries by adsorbed gases, making it difficult to re-wet the capillaries (Gauger, 1945).

Vorres and Kolman (1988) and Vorres and others (1988) conducted drying and rehydration studies of Argonne Premium Coal samples. They concluded that coal rank, particle size, and degree of oxidation affected moisture removal and replacement.

The Argonne Premium Coal samples behave in a typical fashion with respect to rehydration. Improper storage can lead to substantial moisture loss. Resaturation generally will restore some of the lost moisture. These observations on moisture loss are important if measurements of physical properties are to be made on samples that have been stored under noncontrolled conditions for any length of time. These observations are also important for calculations involving chemical analysis of the raw coal (for example, instrumental neutron activation analysis or X-ray fluorescence analysis). Assuming that the coal samples have retained their original moisture contents can lead to errors of as much as 30 percent for low-rank coals (lignites and subbituminous: ND PC-8 and WY PC-2, respectively). Even for higher rank coal (for example, IL PC-3), the errors can be as high as 6.5 percent.

\section{DISCUSSION}

We recommend the following procedures to minimize errors caused by desiccation (especially for low-rank coal):

1. After the ampoules are opened, samples should be stored in a way to minimize dehydration.
2. Moisture content of each coal sample should be determined just prior to chemical analysis of whole coal.

3. If there is insufficient sample for moisture determination, rehydrate the sample to reduce the error.

The ASTM method for determining equilibrium moisture (ASTM, 1996b, D 1412-93) could be used to rehydrate the sample, but the method requires at least a $20-\mathrm{g}$ sample, more time, and more equipment than the procedure described in this paper.

An alternative method would be to analyze a moisturefree sample by drying it $\left(105^{\circ} \mathrm{C}\right.$ for 24 hours) prior to analysis. Two assumptions are necessary: (1) that the published moisture value is applicable so that the chemical analysis can be recalculated to an as-received basis, and (2) that the sample does not pick up moisture between drying and weighing for analysis.

\section{REFERENCES}

Allardice, D.J., and Evans, D.G., 1978, Moisture in coal, in Karr, C.C., Jr., ed., Analytical methods for coal and coal products (v. 1): New York, Academic Press, chap. 7, p. 247-262.

American Society for Testing and Materials (ASTM), 1996a, ASTM Designation D 3173-87, Standard test method for moisture in the analysis sample of coal and coke; 1996 Annual Book of ASTM Standards, v. 05.05, Gaseous fuels; Coal and coke, p. 289-290.

-1996b, ASTM Designation D 1412-93, Standard test method for equilibrium moisture of coal at 96 to 97 percent relative humidity and $30^{\circ} \mathrm{C} ; 1996$ Annual Book of ASTM Standards, v. 05.05, Gaseous fuels; Coal and coke, p. 188191.

Gauger, A.W., 1945, Condition of water in coal, in Lowery, H.H., ed., Chemistry of coal utilization (v. 1): New York, J. Wiley \& Sons, p. 600-626.

Vorres, K.S., 1990, The Argonne Premium Coal Sample Program: Energy and Fuels, v. 4, no. 5, p. 420-426.

1993, Users handbook for the Argonne Premium Coal samples: Argonne National Laboratory [Report] ANL/PCSP93/1, 200 p.

Vorres, K.S., Kolman, R., and Griswold, T., 1988, Kinetics of vacuum drying and rehydration of Illinois \#6 coal samples. Implications for pore structure: Preprints, Fuel Chemistry Division, American Chemical Society, v. 33, no. 2, p. 333342.

Vorres, K.S., and Kolman, R., 1988, Kinetics of the vacuum drying and rehydration in nitrogen of coals from the Argonne Premium Coal Sample Program: Preprints, Fuel Chemistry Division, American Chemical Society, v. 33, no. 3, p. 7-16. 


\title{
Determination of 62 Elements in 8 Argonne Premium Coal Ash Samples by Automated Semiquantitative Direct-Current Arc Atomic Emission Spectrography
}

\author{
By Carol J. Skeen, B.J. Libby, and W.B. Crandell
}

\begin{abstract}
The automated semiquantitative direct-current arc atomic emission spectrographic method was used to determine concentrations of 62 elements in 8 Argonne Premium Coal ash samples. Ashed samples of all eight coals were analyzed in triplicate to verify precision of the method. The precision for most elements was within \pm 10 percent. The accuracy of this method is assumed to be limited to +50 percent or -33 percent because of the nature of the standard curves for each of the elements. Adjustments to the computer program were implemented to account for unique matrix interferences in these particular coal ash samples.
\end{abstract}

\section{INTRODUCTION}

Emission spectrographic analysis is based on the emission of light by atoms and ions returning to ground state after excitation in a direct-current (dc) arc. The light is passed through the slit of a spectrograph and diffracted by a grating. The slit image is focused on a photographic plate. Distinct wavelength positions for each element indicate the presence of that element, and the darkness of the resulting specific slit image is proportional to the concentration of the specific element present.

The automated dc atomic emission spectrographic analysis of a wide variety of geologic materials is a rapid, economical method for evaluating both the major- and trace-element composition. A total of 62 elements can be determined (Dorrzapf, 1973). This computerized procedure is semiquantitative, because it calculates concentrations by using prestored coefficients calculated from previously arced standards.

\section{EXPERIMENTAL}

In preparation of the samples for arcing, $15 \mathrm{mg}$ of the ashed sample ( $-100 \mathrm{mesh})$ was mixed with $30 \mathrm{mg}$ of graphite and transferred to a graphite crater electrode. The stan- dard operating procedures for the spectrographic analysis are listed in table 1 (Dorrzapf and others, 1989). The Helz jet was used in preference to a Stallwood jet, because it simplifies the procedure for changing samples (Stallwood, 1954; Shaw and others, 1958; Helz, 1964). An iron bead

Table 1. Photoplate preparation conditions.

[Table modified from Dorrzapf and others (1989, table 4). A, ampere; ASTM, American Society for Testing and Materials; dc, direct current; L, liter, min, minute; s, second; $V$, volt]

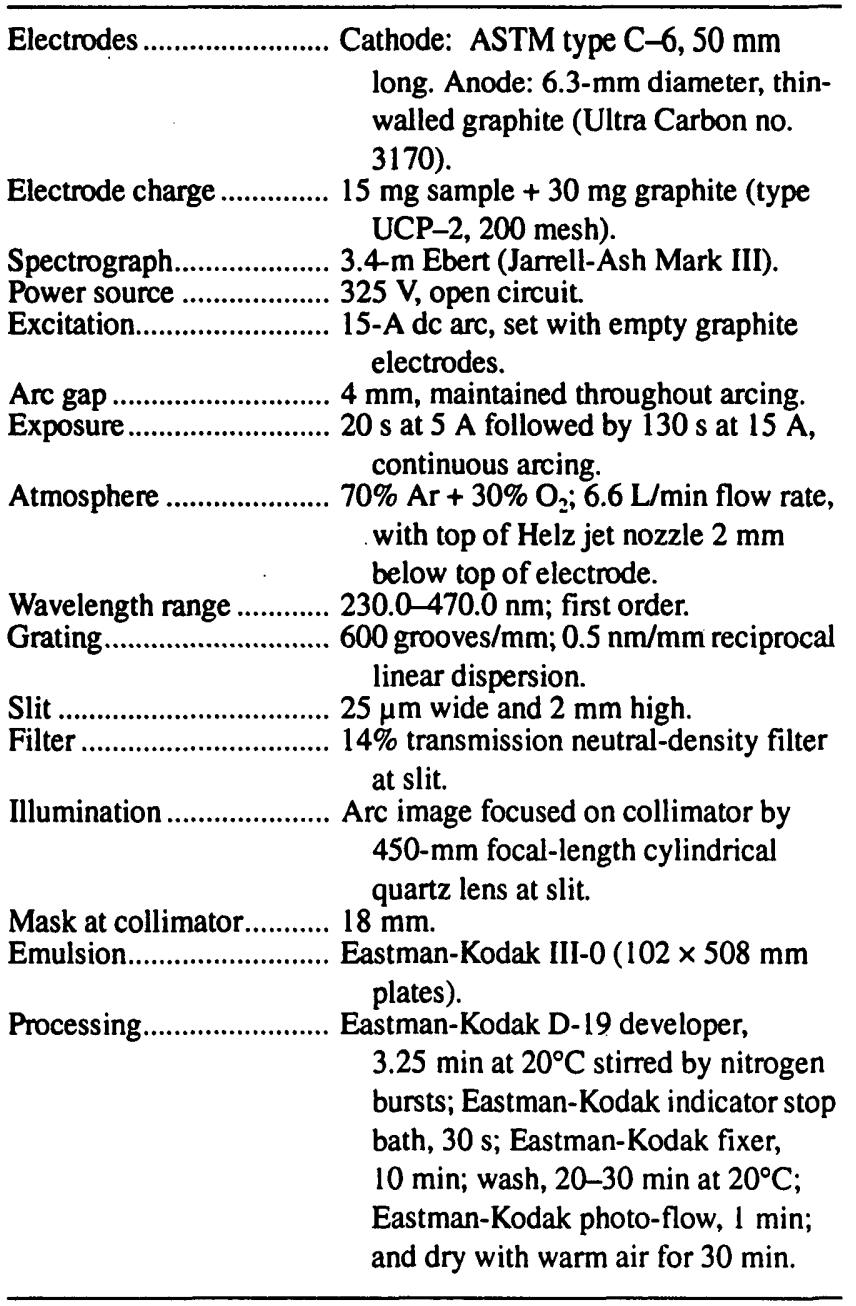


Table 2. Element concentrations determined by direct-current arc spectrographic analyses of NIST standard reference material coal fly ash.

[Concentrations are in percentages (\%) for the first nine elements (Si through $\mathrm{Mn}$ ) and in micrograms per gram ( $\mu \mathrm{g} / \mathrm{g}$ ) for the remaining elements (As through Zr). NIST, National Institute of Standards and Technology, formerly the National Bureau of Standards; SD, standard deviation; USGS, U.S. Geological Survey]

\begin{tabular}{|c|c|c|c|c|}
\hline \multirow[b]{2}{*}{ Element } & \multicolumn{2}{|c|}{ NIST 1633} & \multicolumn{2}{|c|}{ NIST 1633a } \\
\hline & $\begin{array}{l}\text { NIST value } \\
(\text { mean } \pm S D)\end{array}$ & $\begin{array}{c}\text { USGS } \\
\text { average }^{2}\end{array}$ & $\begin{array}{l}\text { NIST value } \\
(\text { mean } \pm \text { SD) }\end{array}$ & $\begin{array}{c}\text { USGS } \\
\text { average }^{3}\end{array}$ \\
\hline 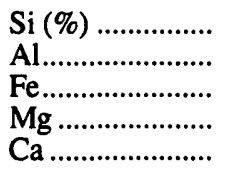 & & $\begin{array}{l}27 \pm 3.3 \\
17 \pm 2.8 \\
8.0 \pm 0.93 \\
2.2 \pm 0.32 \\
5.4 \pm 1.2\end{array}$ & $\begin{array}{l}22.8 \pm 0.8 \\
14 \\
9.40 \pm 0.10 \\
.455 \pm 0.010 \\
1.11 \pm 0.01\end{array}$ & $\begin{array}{l}26 \pm 2.6 \\
18 \pm 3.1 \\
11 \pm 1.7 \\
.71 \pm 0.1 \\
1.3 \pm 0.31\end{array}$ \\
\hline 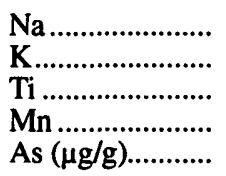 & $\begin{array}{l}1.72 \\
.0493 \pm 0.0007 \\
61 \pm 6\end{array}$ & $\begin{aligned} .25 \pm 0.03 \\
1.3 \pm 0.15 \\
.80 \pm 0.15 \\
.076 \pm 0.11 \\
4<100\end{aligned}$ & $\begin{array}{c}.17 \pm 0.01 \\
1.88 \pm 0.06 \\
.8 \\
.0190 \\
145 \pm 15\end{array}$ & $\begin{array}{l}.16 \pm 0.03 \\
1.5 \pm 0.19 \\
.85 \pm 0.18 \\
.026 \pm 0.08 \\
190 \pm 49\end{array}$ \\
\hline 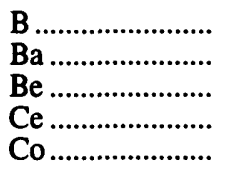 & $\begin{array}{r}430 \\
12 \\
38\end{array}$ & $\begin{array}{c}440 \pm 46 \\
1,600 \pm 490 \\
15 \pm 1.5 \\
170 \pm 29 \\
38 \pm 4.9\end{array}$ & $\begin{array}{r}1,500 \\
12 \\
180 \\
46\end{array}$ & $\begin{array}{c}32 \pm 4.0 \\
910 \pm 160 \\
14 \pm 1.9 \\
160 \pm 53 \\
38 \pm 6.2\end{array}$ \\
\hline 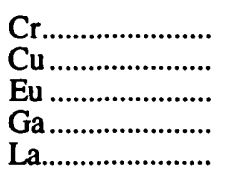 & $\begin{array}{c}131 \pm 2 \\
128 \pm 5 \\
49\end{array}$ & $\begin{array}{c}120 \pm 23 \\
100 \pm 25 \\
3.1 \pm 0.5 \\
39 \pm 5.8 \\
96 \pm 13\end{array}$ & $\begin{array}{c}196 \pm 6 \\
118 \pm 3 \\
4 \\
58\end{array}$ & $\begin{array}{c}180 \pm 33 \\
93 \pm 21 \\
3.4 \pm 0.6 \\
54 \pm 11\end{array}$ \\
\hline 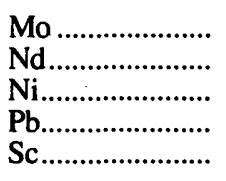 & $\begin{array}{l}98 \pm 3 \\
70 \pm 4\end{array}$ & $\begin{array}{r}60 \pm 15 \\
110 \pm 15 \\
74 \pm 9.0 \\
25 \pm 4.0\end{array}$ & $\begin{array}{c}29 \\
127 \pm 4 \\
72.4 \pm 0.4 \\
40\end{array}$ & $\begin{array}{c}28 \pm 6.2 \\
100 \pm 29 \\
140 \pm 19 \\
76 \pm 12 \\
29 \pm 5.7\end{array}$ \\
\hline 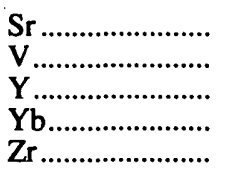 & $\begin{array}{l}1,380 \\
214 \pm 8\end{array}$ & $\begin{aligned} 1,700 & \pm 30 \\
200 & \pm 24 \\
53 & \pm 7.8 \\
6.6 & \pm 0.9 \\
180 & \pm 29\end{aligned}$ & $\begin{array}{l}830 \pm 30 \\
300\end{array}$ & $\begin{array}{l}900 \pm 140 \\
240 \pm 36\end{array}$ \\
\hline
\end{tabular}

\footnotetext{
' Values taken from NIST Certificates 1633 (National Bureau of Standards, 1975) and 1633a (National Bureau of Standards, 1979). Values with no error listed are NIST information values; all others are NIST certified values.

${ }^{2}$ Average of 35 determinations Feb. to July 1983.

${ }^{3}$ Average of 31 determinations June 1983 to Mar. 1984.

${ }^{4}$ Lower limit of determination.
}

was arced first and exposed on the plate for the iron calibration reference spectrum. Then each sample was arced at 5 amperes (A) for 20 seconds and then at $15 \mathrm{~A}$ for $130 \mathrm{sec}-$ onds. For the iron and for each sample and standard, a cadmium lamp was exposed in two windows as a reference to be used on the scanning microphotometer.

The photoplate was developed and processed according to standard U.S. Geological Survey (USGS) procedures (Helz and others, 1969). The intensities of the spectra on the plate were recorded by a scanning microphotometer (Helz, $1965,1973)$. The data were processed by a Hewlett-Packard 2100 computer, and a report was generated with the 62-element concentration information. This report was evaluated by the analyst, who verified the values reported (Golightly and others, 1977; Dorrzapf and others, 1989).

Programs for data collection and interpretation that were written (Walthall, 1974) for use on a mainframe computer were adapted for use on a minicomputer system (Thomas, 1979). The specific details about the procedure for calibration and the algorithm used for calculations were summarized by Dorrzapf and others (1989).

\section{RESULTS AND DISCUSSION}

For eight Argonne Premium Coal samples, an in-depth study was made for specific interference corrections in addi- 
Table 3. Element concentrations determined by direct-current arc spectrographic analyses of the Argonne Premium Coal samples.

[Concentrations are in percentages $(\%)$ for the first 10 elements and in micrograms per gram $(\mu \mathrm{g} / \mathrm{g})$ for the other 52 elements. $\mathrm{H}$, interference]

\begin{tabular}{|c|c|c|c|c|c|c|c|c|c|}
\hline Element & UF PC-1-1 & UF PC-1-2 & UF PC-1-3 & WY PC-2-1 & WY PC-2-2 & WY PC-2-3 & IL PC-3-1 & IL PC-3-2 & IL PC-3-3 \\
\hline 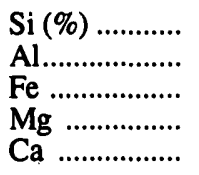 & $\begin{array}{l}22 \\
15 \\
12 \\
.98 \\
5.1\end{array}$ & $\begin{array}{l}22 \\
19 \\
9.9 \\
1.1 \\
4.4\end{array}$ & $\begin{array}{l}25 \\
19 \\
13 \\
1.2 \\
4.7\end{array}$ & $\begin{array}{c}15 \\
5.0 \\
3.0 \\
3.9 \\
12\end{array}$ & $\begin{array}{r}15 \\
6.4 \\
3.0 \\
4.6 \\
15\end{array}$ & $\begin{array}{c}17 \\
7.2 \\
3.6 \\
4.4 \\
17\end{array}$ & $\begin{array}{l}22 \\
12 \\
14 \\
.69 \\
9.6\end{array}$ & $\begin{array}{l}20 \\
12 \\
14 \\
.68 \\
9.4\end{array}$ & $\begin{array}{l}25 \\
13 \\
16 \\
11.77\end{array}$ \\
\hline 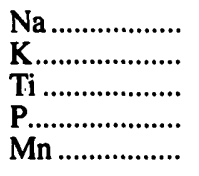 & $\begin{array}{c}.31 \\
2.3 \\
.45 \\
<.068 \\
.041\end{array}$ & $\begin{array}{c}.35 \\
2.1 \\
.29 \\
<.068 \\
.038\end{array}$ & $\begin{array}{c}.34 \\
2.2 \\
.44 \\
<.068 \\
.043\end{array}$ & $\begin{array}{c}1.4 \\
.36 \\
.35 \\
.24 \\
.049\end{array}$ & $\begin{array}{l}1.9 \\
.44 \\
.43 \\
.31 \\
.032\end{array}$ & $\begin{array}{l}1.4 \\
.36 \\
.48 \\
.39 \\
.036\end{array}$ & $\begin{array}{c}.99 \\
1.5 \\
.38 \\
<.068 \\
.066\end{array}$ & $\begin{array}{c}.89 \\
1.6 \\
.40 \\
<.068 \\
.064\end{array}$ & $\begin{array}{c}.91 \\
1.7 \\
.45 \\
<.068 \\
.070\end{array}$ \\
\hline 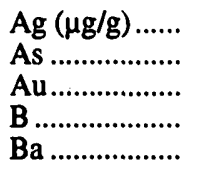 & $\begin{array}{l}1.4 \\
230 \\
<6.8 \\
140 \\
300\end{array}$ & $\begin{array}{l}1.5 \\
280 \\
<6.8 \\
350 \\
320\end{array}$ & $\begin{array}{l}1.6 \\
160 \\
<6.8 \\
180 \\
290\end{array}$ & $\begin{array}{c}<100 \\
<6.8 \\
870 \\
3,400\end{array}$ & $\begin{array}{c}<100^{.85} \\
<6.8 \\
740 \\
3,700\end{array}$ & $\begin{array}{c}<100^{.88} \\
<6.8 \\
860 \\
4,200\end{array}$ & $\begin{array}{c}2.2 \\
<100 \\
<6.8 \\
730 \\
320\end{array}$ & $\begin{array}{c}2.6 \\
<100 \\
<6.8 \\
680 \\
330\end{array}$ & $\begin{array}{l}2.4 \\
100 \\
<6.8 \\
780 \\
470\end{array}$ \\
\hline 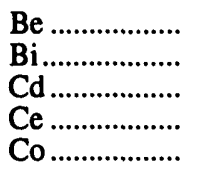 & $\begin{array}{r}11 \\
<10 \\
<32 \\
<63 \\
28\end{array}$ & $\begin{aligned} & 8.9 \\
&< 10 \\
&< 32 \\
& 74 \\
& 22\end{aligned}$ & $\begin{array}{r}11 \\
<10 \\
<32 \\
<63 \\
29\end{array}$ & $\begin{aligned} & 1.6 \\
&<10 \\
&<32 \\
& 74 \\
& 12\end{aligned}$ & $\begin{array}{c}1.6 \\
<10 \\
<32 \\
120 \\
17\end{array}$ & $\begin{array}{c}1.8 \\
<10 \\
<32 \\
110 \\
16\end{array}$ & $\begin{aligned} & 5.5 \\
&< 10 \\
&< 32 \\
&< 200 \\
& 22\end{aligned}$ & $\begin{aligned} & 5.9 \\
&< 10 \\
&< 32 \\
&< 200 \\
& 21\end{aligned}$ & $\begin{array}{c}\quad 6.6 \\
<10 \\
<32 \\
170 \\
26\end{array}$ \\
\hline 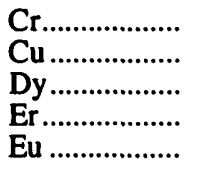 & $\begin{array}{l}160 \\
130 \\
<22 \\
<4.6 \\
<2.2\end{array}$ & $\begin{array}{l}130 \\
120 \\
<22 \\
<4.6 \\
<2.2\end{array}$ & $\begin{array}{l}140 \\
140 \\
<22 \\
<4.6 \\
<2.2\end{array}$ & $\begin{array}{l}56 \\
130 \\
<22 \\
<4.6 \\
<2.2\end{array}$ & $\begin{array}{l}74 \\
160 \\
<22 \\
<4.6 \\
<2.2\end{array}$ & $\begin{array}{l}70 \\
160 \\
<22 \\
<4.6 \\
<2.2\end{array}$ & $\begin{array}{r}220 \\
82 \\
<22 \\
<4.6 \\
<2.2\end{array}$ & $\begin{array}{r}220 \\
69 \\
<22 \\
<4.6 \\
<2.2\end{array}$ & $\begin{array}{r}260 \\
58 \\
<22 \\
<4.6 \\
<2.2\end{array}$ \\
\hline 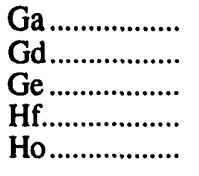 & $\begin{array}{r}45 \\
<32 \\
26 \\
<15 \\
<68\end{array}$ & $\begin{array}{r}47 \\
<32 \\
25 \\
<15 \\
<6.8\end{array}$ & $\begin{array}{r}47 \\
<32 \\
29 \\
<15 \\
<6.8\end{array}$ & $\begin{array}{l}26 \\
<32 \\
<4.6 \\
<15 \\
<6.8\end{array}$ & $\begin{array}{l}31 \\
<32 \\
<4.6 \\
<15 \\
<6.8\end{array}$ & $\begin{array}{l}29 \\
<32 \\
<4.6 \\
<15 \\
<6.8\end{array}$ & $\begin{array}{r}29 \\
<32 \\
52 \\
<15 \\
<6.8\end{array}$ & $\begin{array}{c}27 \\
<32 \\
52 \\
<15 \\
<6.8\end{array}$ & $\begin{array}{r}31 \\
<32 \\
60 \\
<15 \\
<6.8\end{array}$ \\
\hline 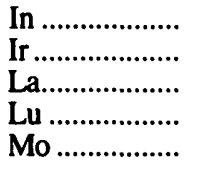 & $\begin{array}{r}<10 \\
<15 \\
64 \\
<15 \\
12\end{array}$ & $\begin{array}{r}<10 \\
<15 \\
39 \\
<15 \\
9.3\end{array}$ & $\begin{array}{r}<10 \\
<15 \\
50 \\
<15 \\
12\end{array}$ & $\begin{array}{c}<10 \\
<15 \\
56 \\
<15 \\
7.6\end{array}$ & $\begin{array}{r}<10 \\
<15 \\
77 \\
<15 \\
7.8\end{array}$ & $\begin{array}{r}<10 \\
<15 \\
84 \\
<15 \\
8.2\end{array}$ & $\begin{array}{r}<10 \\
<15 \\
54 \\
<15 \\
34\end{array}$ & $\begin{array}{r}<10 \\
<15 \\
55 \\
<15 \\
30\end{array}$ & $\begin{array}{r}<10 \\
<15 \\
63 \\
<15 \\
32\end{array}$ \\
\hline 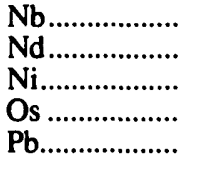 & $\begin{array}{r}12 \\
75 \\
100 \\
<15 \\
77\end{array}$ & $\begin{array}{r}10 \\
<32 \\
95 \\
<15 \\
74\end{array}$ & $\begin{array}{r}15 \\
37 \\
110 \\
<15 \\
82\end{array}$ & $\begin{array}{r}14 \\
<68 \\
57 \\
<15 \\
31\end{array}$ & $\begin{array}{r}15 \\
<68 \\
64 \\
<15 \\
48\end{array}$ & $\begin{array}{r}21 \\
<68 \\
64 \\
<15 \\
41\end{array}$ & $\begin{array}{r}12 \\
<68 \\
130 \\
<15 \\
87\end{array}$ & $\begin{array}{r}14 \\
<68 \\
120 \\
<15 \\
78\end{array}$ & $\begin{array}{c}20 \\
40 \\
150 \\
<15 \\
88\end{array}$ \\
\hline 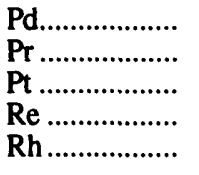 & $\begin{array}{c}<1.0 \\
<100 \\
<2.2 \\
<10 \\
<2.2\end{array}$ & $\begin{array}{c}<1.0 \\
<100 \\
<2.2 \\
<10 \\
<2.2\end{array}$ & $\begin{array}{c}<1.0 \\
<100 \\
<2.2 \\
<10 \\
<2.2\end{array}$ & $\begin{array}{c}<1.0 \\
<100 \\
<2.2 \\
<10 \\
<2.2\end{array}$ & $\begin{array}{c}<1.0 \\
<100 \\
<2.2 \\
<10 \\
<2.2\end{array}$ & $\begin{array}{c}<1.0 \\
<100 \\
<2.2 \\
<10 \\
<2.2\end{array}$ & $\begin{array}{c}<1.0 \\
<100 \\
<2.2 \\
<10 \\
<2.2\end{array}$ & $\begin{array}{c}<1.0 \\
<100 \\
<2.2 \\
<10 \\
<2.2\end{array}$ & $\begin{array}{c}<1.0 \\
<100 \\
<2.2 \\
<10 \\
<2.2\end{array}$ \\
\hline 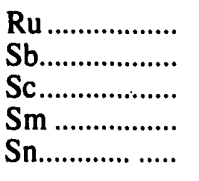 & $\begin{array}{c}<2.2 \\
<68 \\
19 \\
<10 \\
13\end{array}$ & $\begin{array}{r}<2.2 \\
<68 \\
11 \\
<10 \\
12\end{array}$ & $\begin{array}{c}<2.2 \\
<68 \\
16 \\
<10 \\
12\end{array}$ & $\begin{array}{c}<2.2 \\
<68 \\
12 \\
<10 \\
6.4\end{array}$ & $\begin{array}{c}<2.2 \\
<68 \\
17 \\
<10 \\
10\end{array}$ & $\begin{array}{c}<2.2 \\
<68 \\
18 \\
<10 \\
14\end{array}$ & $\begin{array}{l}<2.2 \\
<68 \\
16 \\
<10 \\
10\end{array}$ & $\begin{array}{c}<2.2 \\
<68 \\
16 \\
<10 \\
15\end{array}$ & $\begin{array}{l}<2.2 \\
<68 \\
17 \\
<10 \\
20\end{array}$ \\
\hline 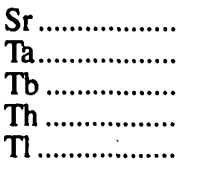 & $\begin{array}{r}490 \\
<320 \\
<32 \\
<46 \\
<10\end{array}$ & $\begin{array}{r}420 \\
<320 \\
<32 \\
<46 \\
<10\end{array}$ & $\begin{array}{r}490 \\
<320 \\
<32 \\
<46 \\
<10\end{array}$ & $\begin{array}{r}2,000 \\
<320 \\
<32 \\
<46 \\
<10\end{array}$ & $\begin{array}{r}2,800 \\
<320 \\
<32 \\
<46 \\
<10\end{array}$ & $\begin{array}{r}3,100 \\
<320 \\
<32 \\
<46 \\
<10\end{array}$ & $\begin{array}{r}250 \\
<320 \\
<32 \\
<46 \\
<10\end{array}$ & $\begin{array}{r}230 \\
<320 \\
<32 \\
<46 \\
<10\end{array}$ & $\begin{array}{r}270 \\
<320 \\
<32 \\
<46 \\
<10\end{array}$ \\
\hline 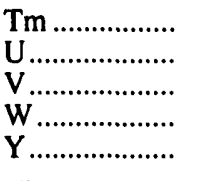 & $\begin{array}{c}<4.6 \\
<220 \\
130 \\
<15 \\
46\end{array}$ & $\begin{array}{r}<4.6 \\
<220 \\
99 \\
<15 \\
22\end{array}$ & $\begin{array}{c}<4.6 \\
<220 \\
130 \\
<15 \\
36\end{array}$ & $\begin{array}{r}<4.6 \\
<220 \\
86 \\
<15 \\
28\end{array}$ & $\begin{array}{c}<4.6 \\
<220 \\
110 \\
<15 \\
36\end{array}$ & $\begin{array}{c}<4.6 \\
<220 \\
120 \\
<15 \\
42\end{array}$ & $\begin{array}{c}<4.6 \\
<220 \\
140 \\
<15 \\
27\end{array}$ & $\begin{array}{c}<4.6 \\
<200 \\
140 \\
<15 \\
29\end{array}$ & $\begin{array}{c}<4.6 \\
<200 \\
160 \\
<15 \\
32\end{array}$ \\
\hline 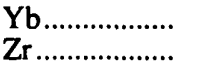 & $\begin{array}{l}6.2 \\
96\end{array}$ & $\begin{array}{l}6.1 \\
55\end{array}$ & $90^{6.4}$ & $140^{2.7}$ & $200^{3.5}$ & $\begin{array}{l}4.1 \\
250\end{array}$ & $\begin{array}{l}3.5 \\
86\end{array}$ & $\begin{array}{l}3.6 \\
96\end{array}$ & $\begin{array}{c}4.2 \\
140\end{array}$ \\
\hline
\end{tabular}


Table 3. Element concentrations determined by direct-current arc spectrographic analyses of the Argonne Premium Coal samplesContinued.

\begin{tabular}{|c|c|c|c|c|c|c|}
\hline Element & PITT PC-4-1 & PITT PC-4-2 & PITT PC-4-3 & POC PC-5-1 & POC PC-5-2 & POC PC-5-3 \\
\hline $\begin{array}{l}\mathrm{Si}(\%) \\
\mathrm{Al} \\
\mathrm{Fe} \\
\mathrm{Mg} \\
\mathrm{Ca}\end{array}$ & $\begin{array}{l}26 \\
24 \\
19 \\
.71 \\
5.0\end{array}$ & $\begin{array}{l}29 \\
21 \\
20 \\
.70 \\
3.6\end{array}$ & $\begin{array}{l}32 \\
24 \\
22 \\
97 \\
4.7\end{array}$ & $\begin{array}{l}18 \\
12 \\
9.8 \\
1.9 \\
10\end{array}$ & $\begin{array}{l}17 \\
14 \\
8.3 \\
2.0 \\
11\end{array}$ & $\begin{array}{l}19 \\
14 \\
10 \\
2.0 \\
12\end{array}$ \\
\hline $\begin{array}{l}\mathrm{Na} \\
\mathrm{K} \\
\mathrm{T} \\
\mathrm{P} \\
\mathrm{M}\end{array}$ & $\begin{array}{c}.42 \\
1.4 \\
.64 \\
<.068 \\
.033\end{array}$ & $\begin{array}{l}.36 \\
1.3 \\
.57 \\
<.068 \\
.041\end{array}$ & $\begin{array}{l}.40 \\
1.5 \\
.64 \\
<.068 \\
.042\end{array}$ & $\begin{array}{l}2.4 \\
.65 \\
.53 \\
<.068 \\
.045\end{array}$ & $\begin{array}{c}2.4 \\
.63 \\
.47 \\
<.068 \\
.043\end{array}$ & $\begin{array}{l}2.5 \\
.73 \\
.58 \\
<.068 \\
.050\end{array}$ \\
\hline $\begin{array}{l}\mathrm{Ag}(\mu \mathrm{g} / \mathrm{g}) \\
\mathrm{As} \ldots \\
\mathrm{Au} . \ldots \ldots \\
\mathrm{B} \\
\mathrm{Ba}\end{array}$ & $\begin{array}{l}210^{.95} \\
<6.8 \\
530 \\
390\end{array}$ & $\begin{array}{l}180^{.94} \\
<6.8 \\
580 \\
370\end{array}$ & $\begin{array}{l}1.0 \\
160 \\
<6.8 \\
570 \\
490\end{array}$ & $\begin{array}{l}1.8 \\
350 \\
<6.8 \\
320 \\
3,600\end{array}$ & $\begin{array}{l}1.8 \\
210 \\
<6.8 \\
310 \\
3,600\end{array}$ & $\begin{array}{c}2.0 \\
270 \\
<6.8 \\
360 \\
4,900\end{array}$ \\
\hline 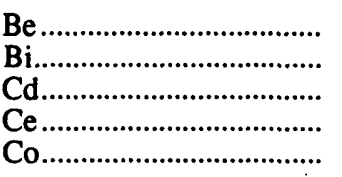 & $\begin{array}{r}12 \\
22 \\
<32 \\
<200 \\
31\end{array}$ & $\begin{array}{r}13 \\
17 \\
<32 \\
<200 \\
25\end{array}$ & $\begin{array}{r}13 \\
<10 \\
<32 \\
<200 \\
30\end{array}$ & $\begin{array}{r}14 \\
<10 \\
<32 \\
220 \\
45\end{array}$ & $\begin{array}{r}11 \\
<10 \\
<32 \\
190 \\
44\end{array}$ & $\begin{array}{r}13 \\
<10 \\
<32 \\
270 \\
56\end{array}$ \\
\hline $\begin{array}{l}\mathrm{Cr} \\
\mathrm{Cu} \\
\mathrm{Dy} . \ldots \ldots \ldots \ldots \\
\mathrm{Er} \\
\mathrm{Eu}\end{array}$ & $\begin{array}{l}220 \\
58 \\
<22 \\
<4.6 \\
<2.2\end{array}$ & $\begin{array}{r}190 \\
89 \\
<22 \\
<4.6 \\
<2.2\end{array}$ & $\begin{array}{r}220 \\
66 \\
<22 \\
<4.6 \\
<2.2\end{array}$ & $\begin{array}{l}170 \\
420 \\
<22 \\
<4.6 \\
<2.2\end{array}$ & $\begin{array}{l}150 \\
290 \\
<22 \\
<4.6 \\
<4.2\end{array}$ & $\begin{array}{l}180 \\
380 \\
<22 \\
<4.6 \\
<2.2\end{array}$ \\
\hline 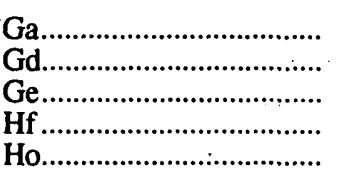 & $\begin{array}{r}57 \\
<32 \\
13 \\
<150 \\
<6.8\end{array}$ & $\begin{array}{r}43 \\
<32 \\
13 \\
<150 \\
<6.8 \\
<\end{array}$ & $\begin{array}{r}54 \\
<32 \\
12 \\
<150 \\
<6.8\end{array}$ & $\begin{array}{r}42 \\
<32 \\
8.7 \\
<15 \\
<6.8\end{array}$ & $\begin{array}{c}40 \\
<32 \\
8.2 \\
<15 \\
<6.8\end{array}$ & $\begin{array}{c}47 \\
<32 \\
\quad 9.2 \\
<15 \\
<6.8\end{array}$ \\
\hline 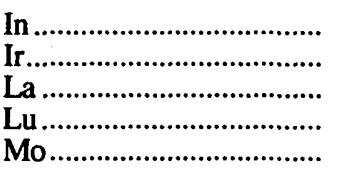 & $\begin{array}{r}<10 \\
<15 \\
60 \\
<15 \\
9.4\end{array}$ & $\begin{array}{r}<10 \\
<15 \\
66 \\
<15 \\
7.4\end{array}$ & $\begin{array}{r}<10 \\
<15 \\
62 \\
<15 \\
9.0\end{array}$ & $\begin{array}{r}<10 \\
<15 \\
130 \\
<15 \\
37\end{array}$ & $\begin{array}{r}<10 \\
<15 \\
130 \\
<15 \\
41\end{array}$ & $\begin{array}{r}<10 \\
<15 \\
150 \\
<15 \\
46\end{array}$ \\
\hline $\begin{array}{l}\mathrm{Nb} \\
\mathrm{Nd} \\
\mathrm{Ni} \\
\mathrm{Os} \\
\mathrm{Pb}\end{array}$ & $\begin{array}{r}18 \\
47 \\
150 \\
<15 \\
79\end{array}$ & $\begin{array}{r}22 \\
46 \\
130 \\
<15 \\
75\end{array}$ & $\begin{array}{r}18 \\
35 \\
150 \\
<15 \\
84\end{array}$ & $\begin{array}{r}24 \\
100 \\
120 \\
<15 \\
220\end{array}$ & $\begin{array}{r}14 \\
130 \\
110 \\
<15 \\
160\end{array}$ & $\begin{array}{r}22 \\
110 \\
140 \\
<15 \\
220\end{array}$ \\
\hline 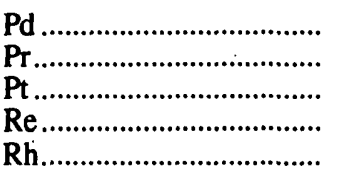 & $\begin{array}{c}<1.0 \\
<100 \\
<2.2 \\
<10 \\
<2.2\end{array}$ & $\begin{array}{c}<1.0 \\
<100 \\
<2.2 \\
<10 \\
<2.2\end{array}$ & $\begin{array}{c}<1.0 \\
<100 \\
<2.2 \\
<10 \\
<2.2\end{array}$ & $\begin{array}{c}<1.0 \\
<100 \\
<2.2 \\
<10 \\
<2.2\end{array}$ & $\begin{array}{c}<1.0 \\
<100 \\
<2.2 \\
<10 \\
<2.2\end{array}$ & $\begin{array}{c}<1.0 \\
<100 \\
<2.2 \\
<10 \\
<2.2\end{array}$ \\
\hline $\begin{array}{l}\mathrm{Ru} \\
\mathrm{Sb} \\
\mathrm{Sc} \\
\mathrm{Sm} \\
\mathrm{Sn}\end{array}$ & $\begin{array}{l}<2.2 \\
<68 \\
20 \\
<10 \\
18\end{array}$ & $\begin{array}{l}<2.2 \\
<68 \\
19 \\
<10 \\
11\end{array}$ & $\begin{array}{l}<2.2 \\
<68 \\
22 \\
<10 \\
13\end{array}$ & $\begin{array}{c}<2.2 \\
<68 \\
24 \\
14 \\
2,800\end{array}$ & $\begin{array}{l}<2.2 \\
<68 \\
24 \\
13 \\
550\end{array}$ & $\begin{array}{l}<2.2 \\
<68 \\
28 \\
16 \\
720\end{array}$ \\
\hline 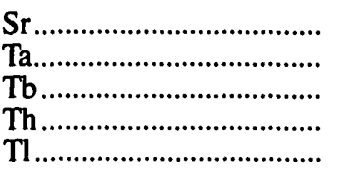 & $\begin{array}{r}960 \\
<320 \\
<32 \\
<46 \\
<10\end{array}$ & $\begin{array}{r}900 \\
<320 \\
<32 \\
<46 \\
<10\end{array}$ & $<32 \begin{array}{r}1,100 \\
<320 \\
\\
<46 \\
<10\end{array}$ & $\begin{array}{r}2,000 \\
<320 \\
<32 \\
<46 \\
<10\end{array}$ & $\begin{array}{l}1,900 \\
<320 \\
<32 \\
<46 \\
<10\end{array}$ & $\begin{array}{l}2,300 \\
<320 \\
<32 \\
<46 \\
<10\end{array}$ \\
\hline 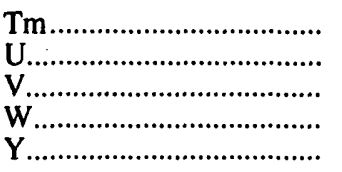 & $\begin{array}{c}<4.6 \\
<220 \\
130 \\
<15 \\
31\end{array}$ & $\begin{array}{c}<4.6 \\
<220 \\
130 \\
<15 \\
36\end{array}$ & $\begin{array}{c}<4.6 \\
<220 \\
150 \\
<15 \\
33\end{array}$ & $\begin{array}{c}<4.6 \\
<220 \\
130 \\
<15 \\
86\end{array}$ & $\begin{array}{c}<4.6 \\
<220 \\
120 \\
<15 \\
81\end{array}$ & $\begin{array}{c}<4.6 \\
<220 \\
150 \\
<15 \\
92\end{array}$ \\
\hline 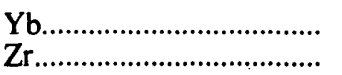 & $110^{6.9}$ & 160 & $\begin{array}{c}5.2 \\
120\end{array}$ & 250 & $200^{8.8}$ & $220^{7.9}$ \\
\hline
\end{tabular}


Table 3. Element concentrations determined by direct-current arc spectrographic analyses of the Argonne Premium Coal samplesContinued.

\begin{tabular}{|c|c|c|c|c|c|c|c|c|c|}
\hline Element & UT PC-6-1 & UT PC-6-2 & UT PC-6-3 & WV PC-7-1 & WV PC-7-2 & WV PC-7-3 & ND PC-8-1 & ND PC-8-2 & ND PC-8-3 \\
\hline 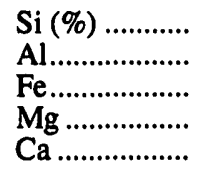 & $\begin{array}{c}16 \\
6.8 \\
4.6 \\
.93 \\
6.0\end{array}$ & $\begin{array}{l}20 \\
7.8 \\
5.9 \\
.82 \\
6.3\end{array}$ & $\begin{array}{l}20 \\
6.3 \\
5.1 \\
.89 \\
6.3\end{array}$ & $\begin{array}{c}22 \\
17 \\
1.8 \\
.66 \\
.40\end{array}$ & $\begin{array}{c}30 \\
22 \\
2.3 \\
.43 \\
.31\end{array}$ & $\begin{array}{l}28 \\
21 \\
2.1 \\
.40 \\
.49\end{array}$ & $\begin{array}{c}5.7 \\
2.2 \\
3.7 \\
5.5 \\
13\end{array}$ & $\begin{array}{c}6.6 \\
3.0 \\
4.5 \\
5.4 \\
14\end{array}$ & $\begin{array}{c}6.6 \\
2.2 \\
3.5 \\
5.3 \\
15\end{array}$ \\
\hline 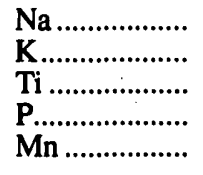 & $\begin{array}{c}1.9 \\
.47 \\
.40 \\
<.068 \\
.014\end{array}$ & $\begin{array}{c}1.4 \\
.31 \\
.43 \\
<.068 \\
.010\end{array}$ & $\begin{array}{c}1.4 \\
.36 \\
.40 \\
<.068 \\
.016\end{array}$ & $\begin{array}{l}.19 \\
2.0 \\
.95 \\
.086 \\
.0092\end{array}$ & $\begin{array}{c}.18 \\
1.7 \\
.91 \\
<.068 \\
.012\end{array}$ & $\begin{array}{c}.19 \\
1.8 \\
.90 \\
<.068 \\
.010\end{array}$ & $\begin{array}{r}\mathrm{H} \\
.40 \\
.18 \\
<.13 \\
.11\end{array}$ & $\begin{array}{l}2.6 \\
.35 \\
.18 \\
.11 \\
.11\end{array}$ & $\begin{array}{l}\mathrm{H} \\
.41 \\
.20 \\
.098 \\
.11\end{array}$ \\
\hline 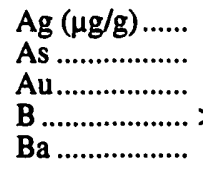 & $\begin{array}{c}12 \\
<220 \\
<6.8 \\
>1,000 \\
750\end{array}$ & $\begin{aligned} & 8.9 \\
&<220 \\
&<6.8 \\
&>1,000 \\
& 670\end{aligned}$ & $\begin{array}{c}9.6 \\
<220 \\
<6.8 \\
>1,000 \\
900\end{array}$ & $\begin{array}{c}2.6 \\
<220 \\
<6.8 \\
150 \\
660\end{array}$ & $\begin{array}{c}2.2 \\
<220 \\
<6.8 \\
480 \\
740\end{array}$ & $\begin{array}{c}2.2 \\
<220 \\
<6.8 \\
250 \\
640\end{array}$ & $\begin{array}{c}<.10 \\
<220 \\
<6.8 \\
500 \\
5,300\end{array}$ & $\begin{array}{c}<.10 \\
<220 \\
<6.8 \\
800 \\
7,400\end{array}$ & $\begin{array}{c}<.10 \\
<220 \\
<6.8 \\
810 \\
5,700\end{array}$ \\
\hline 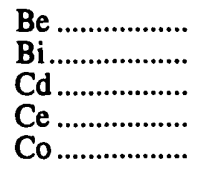 & $\begin{array}{l}3.3 \\
<22 \\
<22 \\
160 \\
15\end{array}$ & $\begin{array}{c}5.2 \\
<22 \\
<22 \\
160 \\
13\end{array}$ & $\begin{array}{c}4.4 \\
<22 \\
<22 \\
130 \\
14\end{array}$ & $\begin{array}{r}15 \\
<22 \\
<22 \\
130 \\
3630\end{array}$ & $\begin{array}{r}16 \\
<22 \\
<22 \\
140 \\
31\end{array}$ & $\begin{array}{c}16 \\
<22 \\
<22 \\
130 \\
5.7\end{array}$ & $\begin{array}{c}2.8 \\
<22 \\
<22 \\
<63 \\
6.0\end{array}$ & $\begin{aligned} & 3.5 \\
&<22 \\
&<22 \\
&<63 \\
& 5.7\end{aligned}$ & $\begin{aligned} & 2.4 \\
&<22 \\
&<22 \\
&<63 \\
& 5.7\end{aligned}$ \\
\hline 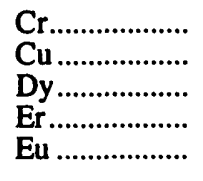 & $\begin{array}{c}110 \\
69 \\
<10 \\
<4.6 \\
<.68\end{array}$ & $\begin{array}{c}85 \\
52 \\
<10 \\
<4.6 \\
<.68\end{array}$ & $\begin{array}{l}120 \\
66 \\
<10 \\
<4.6 \\
2.5\end{array}$ & $\begin{array}{r}220 \\
90 \\
<10 \\
<4.6 \\
2.4\end{array}$ & $\begin{array}{r}180 \\
85 \\
<10 \\
<4.6 \\
2.5\end{array}$ & $\begin{array}{r}210 \\
68 \\
<10 \\
<4.6 \\
4.6\end{array}$ & $\begin{array}{c}25 \\
41 \\
<10 \\
<4.6 \\
<.68\end{array}$ & $\begin{array}{c}25 \\
40 \\
<10 \\
<4.6 \\
<.68\end{array}$ & $\begin{array}{c}26 \\
75 \\
<10 \\
<4.6 \\
<.68\end{array}$ \\
\hline 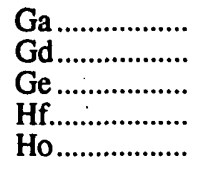 & $\begin{array}{l}32 \\
<22 \\
<4.6 \\
<10 \\
<1.5\end{array}$ & $\begin{array}{l}19 \\
<22 \\
<4.6 \\
<10 \\
<1.5\end{array}$ & $\begin{array}{l}28 \\
<22 \\
<4.6 \\
<10 \\
<1.5\end{array}$ & $\begin{array}{c}68 \\
<22 \\
5.5 \\
<10 \\
3.2\end{array}$ & $\begin{array}{l}56 \\
<22 \\
<4.6 \\
<10 \\
<1.5\end{array}$ & $\begin{array}{c}59 \\
<22 \\
6.2 \\
<10 \\
1.7\end{array}$ & $\begin{array}{l}19 \\
<22 \\
<4.6 \\
<10 \\
<1.5\end{array}$ & $\begin{array}{l}16 \\
<22 \\
<4.6 \\
<10 \\
<1.5\end{array}$ & $\begin{array}{l}20 \\
<22 \\
<4.6 \\
<10 \\
<1.5\end{array}$ \\
\hline 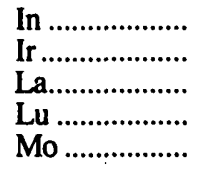 & $\begin{array}{l}<6.8 \\
<10 \\
66 \\
<6.8 \\
12\end{array}$ & $\begin{array}{c}<6.8 \\
<10 \\
64 \\
<6.8 \\
8.4\end{array}$ & $\begin{array}{c}<6.8 \\
<10 \\
62 \\
<6.8 \\
11\end{array}$ & $\begin{array}{c}<6.8 \\
<10 \\
72 \\
<6.8 \\
7.0\end{array}$ & $\begin{array}{c}<6.8 \\
<10 \\
74 \\
<6.8 \\
8.4\end{array}$ & $\begin{array}{c}<6.8 \\
<10 \\
64 \\
<6.8 \\
6.3\end{array}$ & $\begin{array}{c}<6.8 \\
<10 \\
37 \\
<6.8 \\
8.6\end{array}$ & $\begin{array}{c}<6.8 \\
<10 \\
40 \\
<6.8 \\
8.2\end{array}$ & $\begin{array}{c}<6.8 \\
<10 \\
39 \\
<6.8 \\
8.7\end{array}$ \\
\hline 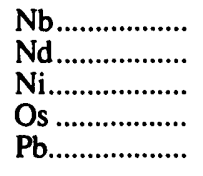 & $\begin{array}{r}10 \\
64 \\
84 \\
<10 \\
45\end{array}$ & $\begin{array}{r}11 \\
<150 \\
89 \\
<10 \\
36\end{array}$ & $\begin{array}{r}12 \\
<150 \\
87 \\
<10 \\
43\end{array}$ & $\begin{array}{r}13 \\
97 \\
120 \\
<10 \\
93\end{array}$ & $\begin{array}{r}19 \\
100 \\
100 \\
<10 \\
81\end{array}$ & $\begin{array}{r}23 \\
90 \\
110 \\
<10 \\
69\end{array}$ & $\begin{aligned} & 6.6 \\
&< 32 \\
& 17 \\
&<10 \\
& 28\end{aligned}$ & $\begin{aligned} & 5.3 \\
&< 32 \\
& 17 \\
&<10 \\
& 22\end{aligned}$ & $\begin{array}{r}6.4 \\
<150 \\
22 \\
<10 \\
32\end{array}$ \\
\hline 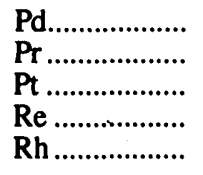 & $\begin{aligned} & <.68 \\
& 9.5 \\
< & 1.5 \\
< & 10 \\
< & <1.5\end{aligned}$ & $\begin{aligned} & <.68 \\
& 9.3 \\
< & 1.5 \\
< & 10 \\
< & <1.5\end{aligned}$ & $\begin{aligned} & <.68 \\
& 8.4 \\
< & 1.5 \\
< & 10 \\
< & 1.5\end{aligned}$ & $\begin{array}{l}<.68 \\
10 \\
<1.5 \\
<10 \\
<1.5\end{array}$ & $\begin{aligned} & <.68 \\
& 9.3 \\
< & 1.5 \\
< & 10 \\
< & 1.5\end{aligned}$ & $\begin{array}{l}\quad<.68 \\
<6.8 \\
<1.5 \\
<10 \\
<1.5\end{array}$ & $\begin{array}{l}<.68 \\
<6.8 \\
<1.5 \\
<10 \\
<1.5\end{array}$ & $\begin{aligned} & <.68 \\
& <6.8 \\
< & <1.5 \\
< & 10 \\
< & <1.5\end{aligned}$ & $\begin{aligned} & <.68 \\
& 7.3 \\
< & 1.5 \\
< & 10 \\
< & <1.5\end{aligned}$ \\
\hline 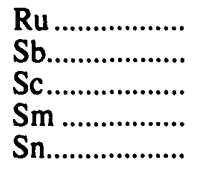 & $\begin{array}{c}<1.0 \\
<32 \\
16 \\
8.0 \\
8.8\end{array}$ & $\begin{array}{c}<1.0 \\
<32 \\
15 \\
8.2 \\
5.9\end{array}$ & $\begin{array}{c}<1.0 \\
<32 \\
14 \\
7.8 \\
9.4\end{array}$ & $\begin{array}{c}<1.0 \\
<32 \\
36 \\
8.9 \\
11\end{array}$ & $\begin{array}{c}<1.0 \\
<32 \\
31 \\
8.7 \\
8.4\end{array}$ & $\begin{array}{l}<1.0 \\
<32 \\
32 \\
<3.2 \\
10\end{array}$ & $\begin{array}{c}<1.0 \\
<32 \\
9.2 \\
<3.2 \\
<4.6\end{array}$ & $\begin{array}{c}<1.0 \\
<32 \\
9.1 \\
<3.2 \\
<4.6\end{array}$ & $\begin{array}{c}<1.0 \\
<32 \\
10 \\
4.9 \\
13\end{array}$ \\
\hline 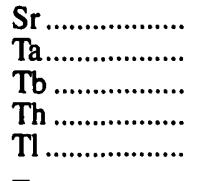 & $\begin{array}{r}1,800 \\
<320 \\
<32 \\
<46 \\
<10\end{array}$ & $\begin{array}{r}2,000 \\
<320 \\
<32 \\
<46 \\
<10\end{array}$ & $\begin{array}{r}2,000 \\
<320 \\
<32 \\
<46 \\
<10\end{array}$ & $\begin{array}{r}390 \\
<320 \\
<32 \\
<46 \\
<10\end{array}$ & $\begin{array}{r}320 \\
<320 \\
<32 \\
<46 \\
<10\end{array}$ & $\begin{array}{r}370 \\
<320 \\
<32 \\
<46 \\
<10\end{array}$ & $\begin{array}{r}6,200 \\
<320 \\
<32 \\
<46 \\
<1015\end{array}$ & $\begin{array}{r}6300 \\
<320 \\
<32 \\
<46 \\
<10\end{array}$ & $\begin{array}{r}7300 \\
<320 \\
<32 \\
<46 \\
<10\end{array}$ \\
\hline 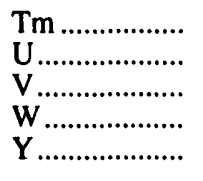 & $\begin{aligned}<3.2 \\
<150 \\
82 \\
<10 \\
41\end{aligned}$ & $\begin{array}{r}<3.2 \\
<150 \\
78 \\
<10 \\
42\end{array}$ & $\begin{array}{r}<3.2 \\
<150 \\
79 \\
<10 \\
34\end{array}$ & $\begin{array}{c}<3.2 \\
<150 \\
160 \\
<10 \\
50\end{array}$ & $\begin{array}{c}<3.2 \\
<150 \\
180 \\
<10 \\
52\end{array}$ & $\begin{array}{c}<3.2 \\
<150 \\
150 \\
<10 \\
39\end{array}$ & $\begin{array}{c}<3.2 \\
<150 \\
38 \\
<10 \\
24\end{array}$ & $\begin{array}{r}<3.2 \\
<150 \\
38 \\
<10 \\
27\end{array}$ & $\begin{array}{r}<3.2 \\
<150 \\
37 \\
<10 \\
25\end{array}$ \\
\hline 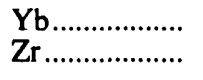 & $260^{4.9}$ & $\begin{array}{c}4.4 \\
280\end{array}$ & 200 & $200^{9.2}$ & $150^{7.3}$ & $140^{7.1}$ & $130^{2.3}$ & $130^{2.0}$ & $\begin{array}{c}2.1 \\
140^{2}\end{array}$ \\
\hline
\end{tabular}


tion to those that were automatically performed. Because of heterogeneity problems associated with barium, coupled with the suppression of the most sensitive analytical lines for barium due to the matrices of these coals, values from less sensitive lines were used. The values for strontium were improved after correcting for interferences from iron and nickel.

This semiquantitative approach achieves ranges and detectability comparable to those of the visual estimation procedure (Myers and others, 1961). Because the standards used do not closely match the approximate composition of the ash samples to be analyzed, the expected accuracy is limited to \pm 1 step, which corresponds to roughly +50 percent or -33 percent of the reported value.

In the analyses of these Premium Coals, the National Institute of Standards and Technology (NIST) standard reference materials NIST 1633 and NIST 1633a (National Bureau of Standards, 1975, 1979) were included as control samples for evaluation of both precision and accuracy of this method. Table 2 lists the concentrations provided by NIST certificates, the mean concentrations determined over a 5-month period, and the associated relative standard deviations. Compositions determined for coal ashes are within the limits of precision and accuracy for which the method was designed. The high relative standard deviations for barium and zirconium indicate the heterogeneity documented for these reference materials (Filby and others, 1985). Heterogeneity possibly explains the large range of values for barium and zirconium in the Premium Coals as well as the interferences discussed above.

Table 3 lists data for all 62 elements in these eight Argonne Premium Coals. The "less than" symbol indicates that the concentration is less than the lower limit for a value that can be determined for that element, and the "greater than" symbol indicates that the concentration is greater than the highest value that can be reliably determined for that element. An " $\mathrm{H}$ " denotes the occurrence of an unresolved interference. Major elements are reported in percentages, and the trace elements in micrograms per gram.

\section{REFERENCES}

Dorrzapf, A.F., Jr., 1973, Spectrochemical computer analysisArgon-oxygen D-C arc method for silicate rocks: U.S. Geological Survey Journal of Research, v. 1, no. 5, p. 559-562.
Dorrzapf, A.F., Jr., Skeen, C.J., and Crandell, W.B., 1989, Automated semiquantitative direct-current arc spectrographic determination of 64 elements in coal ash, in Golightly, D.W., and Simon, F.O., eds., Methods for sampling and inorganic analysis of coal: U.S. Geological Survey Bulletin 1823, p. 21-26.

Filby, R.H., and others, 1985, Evaluation of geochemical standard reference materials for microanalysis: Analytical Chemistry, v. 57, no. 2, p. 551-555.

Golightly, D.W., Dorrzapf, A.F., Jr., and Thomas, C.P., 1977, Sets of spectral lines for spectrographic thermometry and monometry in d.c. arcs of geologic materials: Spectrochimica Acta, v. 32B, p. 313-323.

Helz, A.W., 1964, A gas jet for D-C arc spectroscopy: U.S. Geological Survey Professional Paper 475-D, p. D176-D178.

-1965, The problem of automatic plate reading and computer interpretation for spectrochemical analysis: U.S. Geological Survey Professional Paper 525-B, p. B160-B162.

1973, Spectrochemical computer analysis-Instrumentation: U.S. Geological Survey Journal of Research, v. 1, no. 4, p. $475-482$.

Helz, A.W., Walthall, F.G., and Berman, S., 1969, Computer analysis of photographed optical emission spectra: Applied Spectroscopy, v. 23, p. 508-512.

Myers, A.T., Havens, R.G., and Dunton, P.J., 1961, A spectrochemical method for the semiquantitative analysis of rocks, minerals, and ores: U.S. Geological Survey Bulletin 1084-I, p. 207-215.

National Bureau of Standards, 1975, National Bureau of Standards certificate of analysis, standard reference material 1633, trace elements in coal fly ash: Washington, D.C., National Bureau of Standards, 2 p.

1979, National Bureau of Standards certificate of analysis, standard reference material 1633a, trace elements in coal fly ash: Washington, D.C., National Bureau of Standards, 2 p.

Shaw, D.M., Wickremasenghe, O., and Yip, C., 1958, A simple device for the spectrochemical analysis of minerals in an inert atmosphere using the Stallwood jet: Spectrochimica Acta, v. 13. p. 197-201.

Stallwood, B.J., 1954, Air-cooled electrodes for the spectrochemical analysis of powders: Journal of Optical Society of America, v. 44, p. 171-172.

Thomas, C.P., 1979, A minicomputer-based emission spectrographic analysis system dependent on scanning microphotometry: Applied Spectroscopy, v. 33, p. 604-619.

Walthall, F.G., 1974, Spectrochemical computer analysisProgram description: U.S. Geological Survey Journal of Research, v. 2, no. 1, p. 61-71. 


\title{
Determination of 18 Elements in 5 Whole Argonne Premium Coal Samples by Quantitative Direct-Current Arc Atomic Emission Spectrography
}

\author{
By Janet D. Fletcher and Carol J. Skeen
}

\begin{abstract}
Quantitative multiple-element analysis of whole Argonne Premium Coal samples by direct-current arc atomic emission spectrography is possible with the use of a lithium carbonate buffer. Two spectrographic methods are described for the determination of 18 trace elements in 100 mg samples of coal. Overall concentrations for calibration standards range from a low of $2 \mu \mathrm{g} / \mathrm{g}$ to a high of 3 weight percent. For concentrations well above the lower determination limit, the typical accuracy is within \pm 20 percent, and the general precision of the method is \pm 10 percent.
\end{abstract}

\section{INTRODUCTION}

Most atomic-spectroscopic methods are designed for the analysis of ash from pulverized coals that have been oxidized at $500^{\circ} \mathrm{C}$ or $750^{\circ} \mathrm{C}$ (ASTM, 1984). The direct-current (dc) arc functions well for ash that is mixed with graphite powder, and many elements are effectively preconcentrated by the ashing process, thus providing improved detectability (Dorrzapf, 1973), but certain elements associated with organic phases, such as porphyrins, organometallics, or acid salts, may be volatilized and lost during the ashing process. The elements $\mathrm{Ag}, \mathrm{B}, \mathrm{Ga}, \mathrm{Ge}, \mathrm{Mo}, \mathrm{Ni}$, and $\mathrm{Ti}$, which potentially can be determined by dc arc spectroscopy, are at least partially associated with organic phases in coals (Ruch and others, 1974; Gluskoter and others, 1977; Finkelman, 1980). Direct multiple-element analysis of whole coals circumvents the long intervals required for ashing, the losses due to volatilization, and the further exposure of samples to possible contamination. This paper describes the two directcurrent arc atomic emission spectrographic (DCAES) methods that have produced accurate determinations of 28 elements in the pulverized whole coal (Fletcher and Golightly, 1985). In this study, only 18 elements were determined in 5 Argonne Premium Coals. These methods, which have been applied principally to the analysis of coal microlithotypes, offer the basis for efficient, low-cost, multiple-element analysis of whole coals.
EXPERIMENTAL

Approach

A principal difficulty encountered in attempts to arc small quantities of pulverized coal directly is the rapid evolution of gases that occurs immediately following initiation of the arc and on the subsequent burning of the organic phases that remain in a cup-shaped electrode (anode). The rapidly evolved gases usually blow material from the anode cup, thus creating uncontrolled losses of the previously weighed sample, and the erratic flaming of the organic phase can produce unwanted spectral bands from carbonbased free radicals. These events constitute irreproducible processes that control the transport of material from the hot anode cup into the arc discharge. Such severe problems related to the arcing process have been solved by mixing powdered coal with a lithium carbonate buffer. This controls sample transport and excitation conditions in the arc column and greatly diminishes the possibility for flaming of the hot coal dissociation products. With these important aspects of arcing well controlled for coal samples, the methodology for $\mathrm{dc}$ arc spectrographic analysis becomes quite conventional.

\section{Method}

\section{Preparation of the Samples}

Splits of $100 \mathrm{mg}$ of each whole Argonne Premium Coal sample, $100 \mathrm{mg}$ of lithium carbonate, and $50 \mathrm{mg}$ of pure graphite powder were thoroughly mixed and ground with an agate mortar and pestle to obtain a final homogeneous mixture. For samples that had especially high concentrations of analyte elements, a higher weight ratio of lithium carbonate to sample was necessary, but the ratio was no greater than 10:1. Twenty-five milligrams of the final homogeneous mixture was transferred into the appropriate graphite electrode and firmly tamped (Dorrzapf, 1973). These filled electrodes were dried in an oven at $110^{\circ} \mathrm{C}$ for 4 hours immediately before arcing. The drying step was necessary because it removes water and other readily volatilized com- 
Table 1. Wavelengths, spectral lines, and determination limits for elements that can be determined by the direct-current arc atomic emission spectrography described in this paper.

\begin{tabular}{|c|c|c|c|}
\hline Element & $\begin{array}{l}\text { Wavelength, } \\
(\mathrm{nm})^{1}\end{array}$ & Spectrum $^{1}$ & $\begin{array}{l}\text { Determination } \\
\text { limits }(\%)^{2}\end{array}$ \\
\hline \multicolumn{4}{|c|}{ Group I, involatile elements } \\
\hline $\mathrm{Al}$ & 265.248 & I & $0.01-2.0$ \\
\hline & 266.039 & I & $.01-2.0$ \\
\hline $\mathrm{B}$ & $249.7 \% 3$ & I & $.005-.1$ \\
\hline $\mathrm{Ba} \ldots . . . . . . . . . . . . .$. & 455.403 & II & $.002-.05$ \\
\hline $\mathrm{Ca}$ & 315.887 & II & $.01-3$ \\
\hline & 422.673 & I & $.005-.01$ \\
\hline 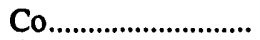 & 345.350 & I & $.0002-.05$ \\
\hline \multirow{2}{*}{$\mathrm{Cr}$} & 302.156 & I & $.002-.2$ \\
\hline & 425.435 & I & $.0002-.02$ \\
\hline $\mathrm{Cu}$ & 327.396 & I & $.0002-.02$ \\
\hline \multirow{2}{*}{$\mathrm{Fe}$} & 259.837 & II & $.05-3$ \\
\hline & 302.107 & I & $.002-1.0$ \\
\hline \multirow[t]{2}{*}{ Mg } & 277.983 & I & $.01-0.2$ \\
\hline & 285.213 & I & $.0002-.02$ \\
\hline \multirow[t]{2}{*}{ 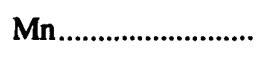 } & 279.482 & I & $.0002-.1$ \\
\hline & 279.827 & I & $.0002-.2$ \\
\hline \multirow{5}{*}{ 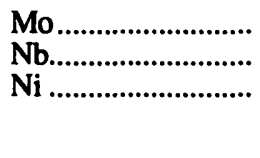 } & 317.035 & I & $.0005-.2$ \\
\hline & 316.340 & II & $.002-.1$ \\
\hline & 305.082 & I & $.002-1$ \\
\hline & 341.476 & I & $.0002-.05$ \\
\hline & 349.296 & I & $.01-.2$ \\
\hline \multirow{3}{*}{ Si } & 251.920 & I & $.2-4$ \\
\hline & 308.940 & II & $.002-.2$ \\
\hline & 316.257 & II & $.005-.2$ \\
\hline \multirow{2}{*}{ 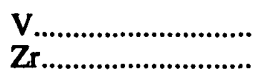 } & 318.341 & I & $.0005-.1$ \\
\hline & 327.926 & II & $.001-.2$ \\
\hline
\end{tabular}

Group II, volatile elements

\begin{tabular}{|c|c|c|c|}
\hline $\begin{array}{l}\mathrm{Ag} \\
\mathrm{As} \\
\mathrm{Bi} \\
\mathrm{Cd} \\
\mathrm{Ga} \\
\mathrm{Ge}\end{array}$ & $\begin{array}{l}338.289 \\
278.020 \\
306.772 \\
326.106 \\
294.364 \\
265.118 \\
303.906 \\
253.652 \\
283.306 \\
317.505 \\
276.787 \\
334.502\end{array}$ & $\begin{array}{l}\text { I } \\
\text { I } \\
\text { I } \\
\text { I } \\
\text { I } \\
\text { I } \\
\text { I } \\
\text { I } \\
\text { I } \\
\text { I } \\
\text { I } \\
\text { I }\end{array}$ & $\begin{array}{l}.0002-.02 \\
.02-.2 \\
.0002-.005 \\
.0002-.1 \\
.0002-.05 \\
.0005-.05 \\
.0002-.005 \\
.002-.1 \\
.0002-.01 \\
.0002-.02 \\
.0002-.02 \\
.001-.05\end{array}$ \\
\hline
\end{tabular}

'Wavelength and spectrum are from the NIST Wavelength Tables (Meggers and others, 1975). I line emitted by normal atom; II line emitted by singly ionized atom.

${ }^{2}$ Lower and upper limits for each element are in units of weight percent.

ponents that could cause the loss of sample material from the anode just after initiation of the arc discharge.

\section{Preparation of Standards}

Calibration standards consisted of homogeneous mixtures of oxides and carbonates of the analyte elements in a lithium carbonate matrix. Dilutions of commercially avail- able standards, which contain 43 elements in lithium carbonate (Spex Industries, Metuchen, New Jersey), provided calibration standards for the concentration range from 1 to $1,000 \mu \mathrm{g} / \mathrm{g}$ for each element of interest. Individual standards were diluted on a weight-weight basis with high-purity lithium carbonate ( $<10 \mu \mathrm{g} / \mathrm{g}$ total impurities).

Reference standards were prepared from the National Institute of Standards and Technology (NIST), formerly the National Bureau of Standards (NBS), coal reference materials NIST 1632, NIST 1632a, and NIST 1635 (NBS, 1974, 1978a,b), which were diluted with lithium carbonate in the same fashion as the samples. Drying and handling of NIST standards followed the procedure used for samples.

\section{Arcing of Samples and Standards}

All samples and standards were arced in an argon-oxygen, or argon, laminar stream that is concentric to the anode and is introduced through an alumina nozzle arrangement known as a Helz jet (Helz, 1964). Both the arcing conditions and the atmosphere were chosen to give complete volatilization of analyte elements from the anode cup into the arc column and to effectively excite those atomic energy levels giving the spectral lines listed in table 1, without causing high spectral background. For the volatile elements (group II, table 1), the objective was to vaporize and to excite these elements over a relatively long interval while distilling insignificant amounts of matrix elements into the arc column. The present method was one adapted from that of Annell (1967) for volatile elements in silicate and carbonate rocks. For elements in chemical forms that exhibit low volatility (group I, table 1), total vaporization of each sample into the arc column was necessary for an accurate determination.

Complete details on the spectrographic equipment and the conditions for arcing samples and for making the necessary measurements are given in table 2. Maintaining a 4-mm gap between the tips of the electrodes was essential to the achievement of the accuracy and precision that this approach is capable of producing.

\section{ACCURACY AND PRECISION}

The accuracy of analysis by DCAES is dependent on the successful element-by-element calibrations of an instrument with standard materials that closely resemble the materials to be analyzed. For coals, the effective matrix of the "arced sample" was modified through the use of a lithium carbonate buffer. This modification of the sample matrix made the arced sample resemble the lithium carbonate matrix of the Spex calibration standards. The quantity of lithium carbonate relative to that of the sample was sufficient to control the fusion, vaporization, transport, and excitation processes. The concentration ranges for the elements 
Table 2. Equipment and operating conditions for direct-current arc atomic emission spectrography.

[A, ampere; ASTM, American Society for Testing and Materials; dc, direct current; min, minute; s, second; T, transmission; V, volt]

\begin{tabular}{|c|c|c|}
\hline Subject & Group I, involatile elements & Group II, volatile elements \\
\hline 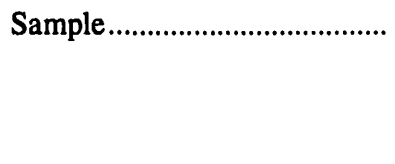 & $\begin{array}{l}100 \mathrm{mg} \text { pulverized whole coal mixed with } 100 \mathrm{mg} \\
\mathrm{Li}_{2} \mathrm{CO}_{3} \text { powder (American Potash) and } 50 \mathrm{mg} \\
\text { graphite powder (-200 mesh, Ultra Carbon); } 25 \\
\text { mg of mixture tamped into anode cup. }\end{array}$ & $\begin{array}{l}100 \mathrm{mg} \text { pulverized whole coal mixed with } 100 \mathrm{mg} \\
\mathrm{Li}_{2} \mathrm{CO}_{3} \text { powder (American Potash) and } 100 \mathrm{mg} \\
\text { graphite powder ( }-200 \text { mesh, Ultra Carbon); } 50 \\
\text { mg of mixture tamped into anode cup. }\end{array}$ \\
\hline 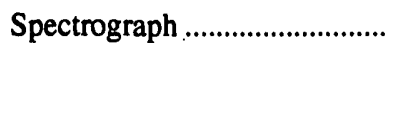 & $\begin{array}{l}\text { Ebert mounting, } 3.4-\mathrm{m} \text { focal length, } 0.5-\mathrm{nm} / \mathrm{mm} \\
\text { reciprocal linear dispersion in first order. } \\
\text { Grating: } 600 \text { grooves } / \mathrm{mm} \text {, blazed for } 300 \mathrm{~nm} \text {. }\end{array}$ & $\begin{array}{l}\text { Eagle mounting, } 3-\mathrm{m} \text { focal length, } 0.55-\mathrm{nm} / \mathrm{mm} \\
\text { reciprocal linear dispersion in first order. } \\
\text { Grating: } 590 \text { grooves } / \mathrm{mm} \text {, blazed for } 300 \mathrm{~nm} \text {. }\end{array}$ \\
\hline Slit & $\begin{array}{l}25 \mu \mathrm{m} \times 2 \mathrm{~mm} \text { for spectra from standards and sam- } \\
\text { ples; } 25 \mu \mathrm{m} \times 4 \mathrm{~mm} \text { for spectra from iron arc. }\end{array}$ & $\begin{array}{l}25 \mu \mathrm{m} \times 2.5 \mathrm{~mm} \text { for spectra from standards and } \\
\text { samples; } 25 \mu \mathrm{m} \times 5 \mathrm{~mm} \text { for spectra from iron arc. }\end{array}$ \\
\hline 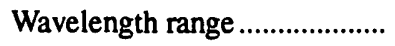 & $240-360 \mathrm{~nm}$, first order & $250-340 \mathrm{~nm}$, second order. \\
\hline Illumination & $\begin{array}{l}\text { Arc image focused on collimator mirror by a } 450- \\
\text { mm focal length cylindrical quartz lens located at } \\
\text { the entrance slit. }\end{array}$ & $\begin{array}{l}\text { Arc image focused on grating by a } 450-\mathrm{mm} \text { focal } \\
\text { length cylindrical quartz lens located near the } \\
\text { entrance slit. }\end{array}$ \\
\hline 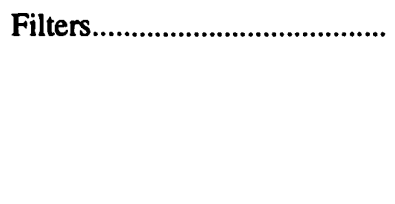 & $\begin{array}{l}\text { Neutral density, } 35 \% \mathrm{~T} \text { plus } 75 \% \mathrm{~T} \text {, for exposures } \\
\text { of samples and standards. Two-step neutral- } \\
\text { density filter, } 40 \% \mathrm{~T}: 100 \% \mathrm{~T} \text {, for iron arc expo- } \\
\text { sures used in calibration of the photographic } \\
\text { emulsion. }\end{array}$ & $\begin{array}{l}\text { None for exposures of samples and standards. Two- } \\
\text { step neutral-density filter, } 50 \% \text { T: } 100 \% \text { T, for } \\
\text { iron arc exposure used in calibration of the pho- } \\
\text { tographic emulsion. }\end{array}$ \\
\hline Electrodes & $\begin{array}{l}\text { Cathode: Graphite rod (Ultra Carbon no. 5001) } 3.2 \\
\text { mm in diameter and } 3.8 \mathrm{~cm} \text { long . } \\
\text { Anode: Thin-walled graphite electrode (Ultra Car- } \\
\text { bon no. 1590) } 3.6 \mathrm{~mm} \text { in diameter. }\end{array}$ & $\begin{array}{l}\text { Cathode: Same as for group I. } \\
\text { Anode: Graphite electrode (Ultra Carbon no. } 3170 \text { ) } \\
5.7 \mathrm{~mm} \text { in diameter. }\end{array}$ \\
\hline Excitation & $\begin{array}{l}\text { Arc current: Stepped arc current, } 5 \mathrm{~A} \mathrm{dc} \text { for } 10 \mathrm{~s}, 15 \\
\text { A dc for } 95 \mathrm{~s} \text {, across constant } 4 \text {-mm arc gap. } \\
\text { Voltage source of } 300 \mathrm{~V} \text {, open circuit. Electrode } \\
\text { supporting the sample is the anode. } \\
\text { Atmosphere: } 80 \% \mathrm{Ar}, 20 \% \mathrm{O}_{2} ; 6.6 \mathrm{~L} / \mathrm{min} \text { through } \\
\text { Helz jet (Helz, 1964). }\end{array}$ & $\begin{array}{l}\text { Arc current: Stepped arc current, } 8 \mathrm{~A} \text { dc for } 10 \mathrm{~s}, 25 \\
\text { A for } 110 \mathrm{~s} \text {, across constant } 4 \text { mm arc gap. Volt- } \\
\text { age source of } 300 \mathrm{~V} \text {, open circuit. Electrode sup- } \\
\text { porting the sample is the anode. } \\
\text { Atmosphere: Ar, } 6.6 \mathrm{~L} / \mathrm{min} \text { through Helz jet (Helz, } \\
\text { 1964). }\end{array}$ \\
\hline 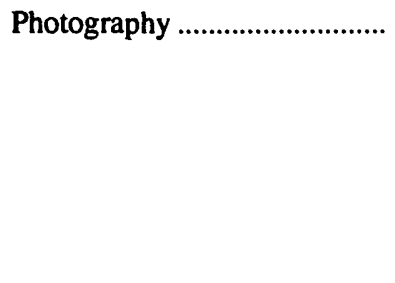 & $\begin{array}{l}\text { Eastman-Kodak III-0 emulsion on } 101-\times 254-\mathrm{mm} \\
\text { glass substrate. Emulsion was processed in } \\
\text { Eastman-Kodak D-19 developer for } 3 \mathrm{~min} \\
\left(20^{\circ} \mathrm{C}\right) \text {, short stop solution for } 30 \mathrm{~s} \text {, and fixer for } \\
10 \mathrm{~min} \text {. Then, the plate was washed in tap water } \\
\text { for } 10 \text { to } 20 \mathrm{~min} \text {, allowed to drain, and dried with } \\
\text { warm air for } 5 \mathrm{~min} \text {. }\end{array}$ & Same as for group I elements. \\
\hline Microphotometry........................... & $\begin{array}{l}\text { All microphotometry was done by conventional } \\
\text { methods, such as those described by ASTM } \\
\text { (ASTM, 1971, p. 79-80). }\end{array}$ & Same as for group I elements. \\
\hline
\end{tabular}

determined by the dc arc spectrographic methods described in this work are summarized in table 1. Elements exhibiting the largest deviations are aluminum, calcium, manganese, and silicon. Experience in the analyses of other coals, vitrinites, exinites, and inertinites indicates that the deviations for the elements observed here are random, rather than systematic. Measurement errors for the spectrographic method for concentrations well above ( $>5$ times) the determination limits are typically \pm 20 percent, and the precision of the method is \pm 10 percent.

\section{RESULTS AND DISCUSSION}

Only five of the eight Argonne Premium Coals were available for analysis when this method was developed. Because this method is labor intensive and the accuracy and precision for this method at the detection limits for a majority of the elements are no better than the other methods implemented in the analysis of these coals, the analyses of the other three coals were not carried out.

Only 18 elements were determined in the 5 whole Argonne Premium Coals. The results of these analyses are 
Table 3. Concentrations (in weight percent) of 7 elements in Argonne Premium Coals determined by directcurrent arc atomic emission spectrography.

\begin{tabular}{|c|c|c|c|c|c|c|c|}
\hline Sample & Mg & Al & $\mathrm{Ca}$ & $\mathrm{Ti}$ & $\mathrm{Mn}$ & $\mathrm{Si}$ & $\mathrm{Fe}$ \\
\hline 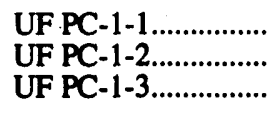 & $\begin{array}{l}0.097 \\
.10 \\
.10\end{array}$ & $\begin{array}{l}2 \\
2 \\
2\end{array}$ & $\begin{array}{r}0.57 \\
.54 \\
.63\end{array}$ & $\begin{array}{r}0.10 \\
.10 \\
.10\end{array}$ & $\begin{array}{r}0.0053 \\
.0059 \\
.0048\end{array}$ & $\begin{array}{l}3 \\
4 \\
3\end{array}$ & $\begin{array}{l}2 \\
3 \\
2\end{array}$ \\
\hline 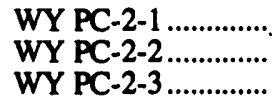 & $\begin{array}{l}.20 \\
.20 \\
.20\end{array}$ & $\begin{array}{l}.47 \\
.54 \\
.44\end{array}$ & $\begin{array}{l}1 \\
1 \\
1\end{array}$ & $\begin{array}{l}.048 \\
.046 \\
.038\end{array}$ & $\begin{array}{l}.0010 \\
.0016 \\
.0014\end{array}$ & $\begin{array}{l}.80 \\
1.0 \\
.52\end{array}$ & $\begin{array}{l}.34 \\
.33 \\
.20\end{array}$ \\
\hline 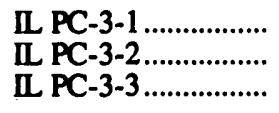 & $\begin{array}{l}.096 \\
.099 \\
.10\end{array}$ & $\begin{array}{l}2 \\
2 \\
2\end{array}$ & $\begin{array}{l}2 \\
2 \\
1\end{array}$ & $\begin{array}{l}.089 \\
.10 \\
.086\end{array}$ & $\begin{array}{l}.015 \\
.015 \\
.017\end{array}$ & $\begin{array}{l}3 \\
4 \\
3\end{array}$ & $\begin{array}{l}2 \\
2 \\
3\end{array}$ \\
\hline $\begin{array}{l}\text { PITT PC-41 } \\
\text { PITT PC-42........... } \\
\text { PITT PC-4-3 ............... }\end{array}$ & $\begin{array}{l}.045 \\
.048 \\
.052\end{array}$ & $\begin{array}{l}1 \\
2 \\
2\end{array}$ & $\begin{array}{l}.24 \\
.34 \\
.28\end{array}$ & $\begin{array}{l}.086 \\
.090 \\
.097\end{array}$ & $\begin{array}{l}.0016 \\
.0028 \\
.0018\end{array}$ & $\begin{array}{l}2 \\
3 \\
2\end{array}$ & $\begin{array}{l}1 \\
1 \\
2\end{array}$ \\
\hline 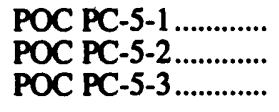 & $\begin{array}{l}.079 \\
.074 \\
.079\end{array}$ & $\begin{array}{l}.80 \\
.92 \\
.84\end{array}$ & $\begin{array}{l}.69 \\
.93 \\
.79\end{array}$ & $\begin{array}{l}.084 \\
.084 \\
.078\end{array}$ & $\begin{array}{l}.0016 \\
.0024 \\
.0017\end{array}$ & $\begin{array}{l}.83 \\
1.0 \\
.80\end{array}$ & $\begin{array}{l}.60 \\
.80 \\
.68\end{array}$ \\
\hline
\end{tabular}

Table 4. Concentrations (in micrograms per gram) of 11 elements in Argonne Premium Coals determined by direct-current arc atomic emission spectrography.

\begin{tabular}{|c|c|c|c|c|c|c|c|c|c|c|c|}
\hline Sample & v & $\mathrm{Cr}$ & $\mathrm{Ni}$ & $\mathrm{Cu}$ & $\mathrm{Zn}$ & Ga & Co & Ge & $\mathrm{Zr}$ & $\mathrm{Ba}$ & $\mathrm{Pb}$ \\
\hline 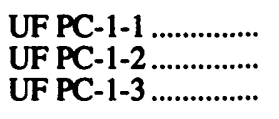 & $\begin{array}{l}38 \\
45 \\
41\end{array}$ & $\begin{array}{l}32 \\
38 \\
26\end{array}$ & $\begin{array}{l}22 \\
29 \\
24\end{array}$ & $\begin{array}{l}20 \\
18 \\
16\end{array}$ & $\begin{array}{l}30 \\
30 \\
40\end{array}$ & $\begin{array}{r}11 \\
11 \\
8\end{array}$ & $\begin{array}{l}5 \\
5 \\
5\end{array}$ & $\begin{array}{l}4 \\
4 \\
3\end{array}$ & $\begin{array}{l}36 \\
29 \\
34\end{array}$ & $\begin{array}{l}88 \\
72 \\
84\end{array}$ & $\begin{array}{r}8 \\
10 \\
6\end{array}$ \\
\hline 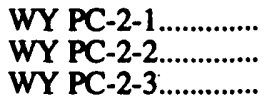 & $\begin{array}{l}10 \\
14 \\
17\end{array}$ & $\begin{array}{l}8 \\
6 \\
8\end{array}$ & $\begin{array}{l}<10 \\
<10 \\
<10\end{array}$ & $\begin{array}{r}5 \\
10 \\
6\end{array}$ & $\begin{array}{l}<20 \\
<20 \\
<20\end{array}$ & $\begin{array}{l}4 \\
2 \\
3\end{array}$ & $\begin{array}{l}<5 \\
<5 \\
<5\end{array}$ & $\begin{array}{l}<2 \\
<2\end{array}$ & $\begin{array}{l}<20 \\
<20 \\
<20\end{array}$ & $\begin{array}{l}200 \\
260 \\
300\end{array}$ & $\begin{array}{l}<2 \\
<2\end{array}$ \\
\hline 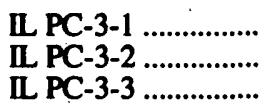 & $\begin{array}{l}52 \\
59 \\
44\end{array}$ & $\begin{array}{l}54 \\
57 \\
47\end{array}$ & $\begin{array}{l}28 \\
35 \\
37\end{array}$ & $\begin{array}{r}9 \\
10 \\
9\end{array}$ & $\begin{array}{l}250 \\
260 \\
320\end{array}$ & $\begin{array}{l}8 \\
5 \\
7\end{array}$ & $\begin{array}{l}<5 \\
<5 \\
<5\end{array}$ & $\begin{array}{r}8 \\
7 \\
12\end{array}$ & $\begin{array}{l}22 \\
25 \\
16\end{array}$ & $\begin{array}{r}140 \\
120 \\
92\end{array}$ & $\begin{array}{l}9 \\
8 \\
6\end{array}$ \\
\hline $\begin{array}{l}\text { PITT PC-4-1............ } \\
\text { PITT PC-4-2........... } \\
\text { PITT PC-4-3.......... }\end{array}$ & $\begin{array}{l}20 \\
25 \\
27\end{array}$ & $\begin{array}{l}23 \\
27 \\
21\end{array}$ & $\begin{array}{l}13 \\
14 \\
11\end{array}$ & $\begin{array}{l}5 \\
6 \\
7\end{array}$ & $\begin{array}{l}20 \\
30 \\
30\end{array}$ & $\begin{array}{l}6 \\
5 \\
5\end{array}$ & $\begin{array}{l}<5 \\
<5 \\
<5\end{array}$ & $\begin{array}{l}3 \\
<2 \\
<2\end{array}$ & $\begin{array}{l}23 \\
21 \\
28\end{array}$ & $\begin{array}{l}66 \\
72 \\
60\end{array}$ & $\begin{array}{l}4 \\
3 \\
5\end{array}$ \\
\hline $\begin{array}{l}\text { POC PC-5-1 } \\
\text { POC PC-5.......... } \\
\text { POC PC-5-3 }\end{array}$ & $\begin{array}{l}16 \\
21 \\
18\end{array}$ & $\begin{array}{l}17 \\
17 \\
14\end{array}$ & $\begin{array}{r}11 \\
11 \\
<10\end{array}$ & $\begin{array}{l}18 \\
13 \\
27\end{array}$ & $\begin{array}{l}<20 \\
<20 \\
<20\end{array}$ & $\begin{array}{l}4 \\
3 \\
4\end{array}$ & $\begin{array}{l}5 \\
5 \\
5\end{array}$ & $\begin{array}{l}<2 \\
<2 \\
<2\end{array}$ & $\begin{array}{l}25 \\
34 \\
32\end{array}$ & $\begin{array}{l}400 \\
460 \\
500\end{array}$ & $\begin{array}{l}5 \\
4 \\
5\end{array}$ \\
\hline
\end{tabular}

shown in tables 3 and 4 . The determination of silver, boron, and molybdenum required special treatment and preparation time, and so they were eliminated from the routine for analysis. As, $\mathrm{Bi}, \mathrm{Cd}, \mathrm{Hg}, \mathrm{Nb}, \mathrm{Sn}$, and $\mathrm{Tl}$ were not determined because of the nature of the matrix of these particular coals.

\section{REFERENCES}

American Society for Testing and Materials (ASTM), 1971, Methods for emission spectrochemical analysis, general practices, nomenclature, tentative methods, suggested methods (6th ed.): Philadelphia, ASTM, 1094 p.

1984, ASTM Designation D 3683-83, Trace elements in coal and coal ash by the atomic absorption method: 1984 Annual Book of ASTM Standards, v. 05.05, Gaseous fuels; Coal and coke, p. 466-469.

Annell, C.S., 1967, Spectrographic determination of volatile elements in silicates and carbonates of geologic interest using an argon dc arc: U.S. Geological Survey Professional Paper 575C, p. Cl32-C136.

Dorrzapf, A.F., Jr., 1973, Spectrochemical computer analysisArgon-oxygen D-C arc method for silicate rocks: U.S. Geological Survey Journal of Research, v. 1, no. 5, p. 559-562. 
Finkelman, R.B., 1980, Modes of occurrence of trace elements in coal: College Park, Md., University of Maryland, Ph.D. dissertation.

Fletcher, J.D., and Golightly, D.W., 1985, The determination of 28 elements in whole coal by direct-current arc spectrography: U.S. Geological Survey Open-File Report 85-204, 14 p.

Gluskoter, H.J., Ruch, R.R., Miller, W.G., Cahill, R.A., Dreher, G.B., and Kuhn, J.K., 1977, Trace elements in coal-Occurrence and distribution: Illinois State Geological Survey Circular 499, 154 p.

Helz, A.W., 1964, A gas jet for D-C arc spectroscopy: U.S. Geological Survey Professional Paper 475-D, p. D176-D178.

Meggers, W.F., Corliss, C.H., and Scribner, B.F., 1975, Tables of spectral line intensities, Part 1 -arranged by elements $(2 \mathrm{~d}$ ed.): Washington, D.C., National Bureau of Standards Monograph $145,387 \mathrm{p}$.
National Bureau of Standards, 1974, National Bureau of Standards certificate of analysis, standard reference material 1632, trace elements in coal (bituminous): Washington, D.C., National Bureau of Standards, $2 \mathrm{p}$.

1978a, National Bureau of Standards certificate of analysis, standard reference material 1632a, trace elements in coal (bituminous): Washington, D.C., National Bureau of Standards, 2 p.

1978b, National Bureau of Standards certificate of analysis, standard reference material 1635 , trace elements in coal (subbituminous): Washington, D.C., National Bureau of Standards, 2 p.

Ruch, R.R., Gluskoter, H.J., and Shimp, N.F., 1974, Occurrence and distribution of potentially volatile trace elements in coal-A final report: Illinois State Geological Survey Environmental Geology Notes, no. 72, 96 p. 


\title{
Determination of Major and Trace Elements in Eight Argonne Premium Coal Samples (Ash and Whole Coal) by $\mathrm{X}$-Ray Fluorescence Spectrometry
}

\author{
By John R. Evans, George A. Sellers, Robert G. Johnson, Davison V. Vivit, and Judy Kent
}

\begin{abstract}
$\mathrm{X}$-ray fluorescence (XRF) spectrometric methods were used in the analysis of eight Argonne Premium Coal samples. Trace elements $(\mathrm{Cr}, \mathrm{Ni}, \mathrm{Cu}, \mathrm{Zn}, \mathrm{Rb}, \mathrm{Sr}, \mathrm{Y}, \mathrm{Zr}, \mathrm{Nb}, \mathrm{Ba}$, $\mathrm{La}$, and $\mathrm{Ce}$ ) in both coal ash and whole coal were determined by energy-dispersive X-ray fluorescence spectrometry. Major elements ( $\mathrm{Na}, \mathrm{Mg}, \mathrm{Al}, \mathrm{Si}, \mathrm{P}, \mathrm{S}, \mathrm{K}, \mathrm{Ca}, \mathrm{Ti}, \mathrm{Mn}$, and $\mathrm{Fe}$ ) in coal ash and trace elements ( $\mathrm{Cl}$ and $\mathrm{P})$ in whole coal were determined by wavelength-dispersive $\mathrm{X}$-ray fluorescence spectrometry. The experimental XRF methods and procedures used to determine these major and trace elements are described.
\end{abstract}

\section{INTRODUCTION}

Energy-dispersive X-ray fluorescence (EDXRF) spectrometry and wavelength-dispersive X-ray fluorescence (WDXRF) spectrometry are used routinely in the determination of major and trace elements in silicate rocks (Norrish and Hutton, 1969; Johnson, 1984); however, the analysis of whole coals by XRF spectrometric techniques is more difficult because of the problem of the very light coal matrix and the scarcity of reliable coal standards. Because coal ash is more similar to silicate matrix rocks, EDXRF and WDXRF techniques developed for silicates can be used for the determination of major and trace elements in coal ash samples.

The rapidity, sensitivity, accuracy, and precision of $\mathrm{X}$ ray fluorescence spectrometric methods are well documented for a wide range of geologic materials (Rose and others, 1963; Norrish and Hutton, 1969; Johnson, 1984; Johnson and others, 1986; Johnson and Fleming, 1987; Evans and Jackson, 1989). Analysis of whole coal by XRF spectrometric techniques has also proven to be successful in many studies (Kuhn and others, 1975; Johnson and others, 1989). Therefore, the determinations of major and minor elements in eight Argonne Premium Coal samples by XRF spectrometric techniques contributed an important part of the geochemical data base compiled for these materials.
This study was not intended to include interpretations of the differences of behavior between various coal ranks of the samples studied.

\section{EXPERIMENTAL}

\section{Coal Ash-EDXRF}

All the Argonne Premium Coal samples were first ashed at $525^{\circ} \mathrm{C}$. This is a lower temperature than prescribed by the American Society for Testing and Materials (ASTM, 1996) method $\left(750^{\circ} \mathrm{C}\right)$; however, our method eliminated all combustible material while retaining the same or higher concentrations of volatile material. Sample preparation of coal ash samples followed procedures described in other publications (Johnson, 1984; Johnson and others, 1986; Evans and Jackson, 1989). A Kevex 700 EDXRF spectrometer with a Kevex 8000 analyzer was used to fluoresce coal ash samples powdered to approximately 100 mesh. These powders were pressed into cups made of Mylar film (6.35 $\mu \mathrm{m})$ pulled tightly over an aluminum ring with a Teflon collar. The resultant surface appears to be planar.

Appropriate secondary targets were used (table 1). Each sample was fluoresced, and intensity measurements were determined after making background and spectral overlap corrections. The ratio of the analyte line intensity to the secondary target Compton scatter intensity was used in determining elemental concentrations. The Compton ratio method corrects for matrix effects, particle size variations, packing density variations, heterogeneity effects, instru-

Table 1. Secondary targets used for EDXRF analysis.

\begin{tabular}{|c|c|}
\hline Element & Secondary target \\
\hline $\begin{array}{l}\mathrm{Cr} \\
\mathrm{Ni}, \mathrm{Cu}, \mathrm{Zn} \ldots \\
\mathrm{Rb}, \mathrm{Sr}, \mathrm{Y}, \mathrm{Zr}, \mathrm{Nb} . . . . . . . . . . . . \\
\mathrm{Ba}, \mathrm{La}, \mathrm{Ce}\end{array}$ & $\begin{array}{l}\mathrm{Fe} \\
\mathrm{Ge} \\
\mathrm{Ag} \\
\mathrm{Gd}\end{array}$ \\
\hline
\end{tabular}


mental fluctuations, and other sources of error inherent in EDXRF determinations.

Trace-element concentrations for coal ash samples were determined from calibration graphs that were constructed by plotting intensity ratio versus the known concentrations for a selected set of standard reference materials (Abbey, 1983).

\section{Whole Coal-EDXRF}

Whole-coal samples were prepared by using procedures similar to those described for EDXRF analyses of the coal ash (Johnson, 1984; Johnson and others, 1986; Evans and Jackson, 1989). All intensity measurements were made on a Kevex 700 spectrometer with a Kevex 7000 analyzer. Each whole-coal sample was fluoresced using a secondary target (table 1). Corrections for background interferences and spectral line overlaps were made before integration of the analyte line intensity. Trace elements in whole coal samples were determined by EDXRF by using interelement influence coefficients calculated from fundamental parameters (Johnson and Fleming, 1987). Characterizations of the coal samples by other analytical techniques must be made before trace-element determinations can be obtained with this method. Even though carbon, hydrogen, nitrogen, and oxygen constitute the largest percentage of the whole coal, these elements have very little bearing on absorption and enhancement effects. Major-element concentrations, as determined from the coal ash (see the next section, "Coal Ash-WDXRF"), identify the most important influences on absorption and enhancement effects necessary to generate accurate interelement influence coefficients from the fundamental parameters algorithm.

The complexities of the fundamental parameters algorithms used in this study are beyond the scope of this paper. Detailed explanations of all equations and variables inherent in the matrix correction procedures were given by Sherman (1959), Rousseau (1984a,b), and Johnson and Fleming (1987).

The lack of a sufficient number of whole-coal standards and the ultimate degradation over time of these standards are major difficulties involved in the characterization of coals. For these reasons, it is not possible to construct routine calibration graphs of standard reference materials for elements of interest; therefore, we must use the fundamental parameters algorithm. Using this algorithm allows the investigator to make accurate trace-element determinations in whole coal with as few as one well-characterized standard. In this study, the National Institute of Standards and Technology (NIST), formerly the National Bureau of Standards (NBS), whole-coal reference materials, NIST 1632a and NIST 1632b (NBS, 1978a, 1985) were used to calculate pure element intensities.

\section{Coal Ash-WDXRF}

The fusion method was used to produce glass disks of coal ash samples (Johnson and others, 1989). This method eliminates the need for matrix correction routines, since the significant dilution of the sample by the flux corrects for heterogeneity effects, particle size variations, and other sources of error from instrumental fluctuations. A sample/ flux ratio is chosen to yield linear calibration curves over the range of concentrations found in both samples and standards, without the use of a heavy absorber, such as $\mathrm{La}_{2} \mathrm{O}_{3}$. This sample/flux ratio is needed because of the low final concentrations of sample components in the sample/flux mix.

A 1:9 dilution of sample to flux is obtained by mixing $0.600 \mathrm{~g}$ of the coal ash with $5.400 \mathrm{~g}$ of a 2:1 mixture of lithium tetraborate to lithium metaborate. This mixture is carefully transferred to a platinum-gold crucible, and three drops of a 15 percent hydrobromic acid solution are added as a wetting agent. An automatic Claisse fluxer is used to heat $/ \mathrm{mix}$ the sample to temperatures reaching $1,200^{\circ} \mathrm{C}$ for approximately 20 minutes. After the sample cools to room temperature, a thin glass disk with a planar analytical surface is produced, which is adequate for WDXRF analysis. Elemental intensity measurements are made on a Diano XRD-8300 wavelength-dispersive X-ray fluorescence spectrometer.

Standards used in the construction of calibration graphs were silicate matrix materials selected from those tabulated by Abbey (1983). Because the coal ash matrix closely resembles silicate materials in composition, calibration graphs obtained from silicate standard reference materials are reliable for major-element determinations in coal ash. Standards are prepared for WDXRF analysis in a manner identical to that described above. Calibration graphs were constructed by plotting the analyte intensity with the known concentration for a selected set of standard reference materials for each element of interest. The intensities for the major elements in the coal ash samples were then used in the individual calibration graphs.

A set of synthetic silicate standards was spiked with sulfur before fusion because the chemical matrix of typical silicate rock standards does not have sulfur concentrations similar to those in the coal ash matrix. Because some sulfur is volatilized during fusion, a portion of the fused standard was analyzed by a LECO sulfur analyzer to determine the actual sulfur concentration in the standard. The sulfur determinations of the standards were used to prepare calibration graphs like those described above for the silicate matrix materials tabulated by Abbey (1983).

\section{Whole Coal-WDXRF (Determination of $\mathrm{Cl}$ and $\mathrm{P}$ )}

Briquettes of the whole-coal samples were produced by mixing $0.500 \mathrm{~g}$ of the coal with $0.500 \mathrm{~g}$ of microgranular 
Table 2. Major-oxide concentrations (in weight percent) in coal ash determined by WDXRF (reported on an ash basis).

[nd, not determined]

\begin{tabular}{|c|c|c|c|c|c|c|c|c|c|c|c|}
\hline Coal sample & $\mathrm{Na}_{2} \mathrm{O}$ & $\mathrm{MgO}$ & $\mathrm{Al}_{2} \mathrm{O}_{3}$ & $\mathrm{SiO}_{2}$ & $\mathrm{P}_{2} \mathrm{O}_{3}$ & $\mathrm{SO}_{3}$ & $\mathrm{~K}_{2} \mathrm{O}$ & $\mathrm{CaO}$ & $\mathrm{TiO}_{2}$ & $\mathrm{MnO}$ & $\mathrm{Fe}_{2} \mathrm{O}_{3}$ \\
\hline $\begin{array}{l}\text { UF PC- } 1-1 \ldots \ldots \ldots \ldots . . \\
\text { UF PC- } 1-2 \ldots \ldots \ldots \ldots \ldots \\
\text { UF PC- } 1-3 \ldots \ldots \ldots \ldots \ldots \ldots\end{array}$ & $\begin{array}{r}0.3 \\
.2 \\
\text { nd }\end{array}$ & $\begin{array}{l}1.0 \\
1.0 \\
\text { nd }\end{array}$ & $\begin{array}{c}21.6 \\
21.6 \\
\text { nd }\end{array}$ & $\begin{array}{c}41.9 \\
42.7 \\
\text { nd }\end{array}$ & $\begin{array}{r}0.1 \\
.1 \\
\text { nd }\end{array}$ & $\begin{array}{l}1.0 \\
\text { nd } \\
\text { nd }\end{array}$ & $\begin{array}{l}2.4 \\
2.5 \\
\text { nd }\end{array}$ & $\begin{array}{l}4.1 \\
4.2 \\
\text { nd }\end{array}$ & $\begin{array}{l}1.0 \\
1.0 \\
\text { nd }\end{array}$ & $\begin{array}{l}<0.1 \\
<.1 \\
\text { nd }\end{array}$ & $\begin{array}{c}21.0 \\
19.9 \\
\text { ind }\end{array}$ \\
\hline 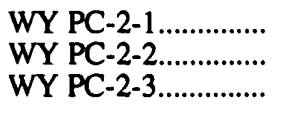 & $\begin{array}{l}1.6 \\
1.3 \\
\text { nd }\end{array}$ & $\begin{array}{l}4.9 \\
5.2 \\
\text { nd }\end{array}$ & $\begin{array}{l}15.0 \\
14.9 \\
\text { nd }\end{array}$ & $\begin{array}{c}31.0 \\
31.5 \\
\text { nd }\end{array}$ & $\begin{array}{r}.7 \\
.7 \\
\text { nd }\end{array}$ & $\begin{array}{l}6.4 \\
9.9 \\
\text { nd }\end{array}$ & $\begin{array}{r}.4 \\
.4 \\
\text { nd }\end{array}$ & $\begin{array}{c}18.1 \\
18.9 \\
\text { nd }\end{array}$ & $\begin{array}{l}1.0 \\
1.0 \\
\text { nd }\end{array}$ & $\begin{array}{l}<.1 \\
<.1 \\
\text { nd }\end{array}$ & $\begin{array}{l}5.6 \\
5.4 \\
\text { nd }\end{array}$ \\
\hline $\begin{array}{l}\text { IL PC-3-1 } \\
\text { IL PC-3-2 } \\
\text { IL PC-3 } 3 \ldots \ldots \ldots \ldots \ldots \ldots \ldots \ldots \ldots \ldots \ldots \ldots\end{array}$ & $\begin{array}{r}1.1 \\
.8 \\
\text { nd }\end{array}$ & $\begin{array}{r}.9 \\
.9 \\
\text { nd }\end{array}$ & $\begin{array}{l}14.1 \\
14.0 \\
\text { nd }\end{array}$ & $\begin{array}{c}40.2 \\
40.2 \\
\text { nd }\end{array}$ & $\begin{array}{r}.1 \\
.1 \\
\text { nd }\end{array}$ & $\begin{array}{l}4.0 \\
3.6 \\
\text { nd }\end{array}$ & $\begin{array}{l}1.5 \\
1.5 \\
\text { nd }\end{array}$ & $\begin{array}{l}7.8 \\
7.7 \\
\text { nd }\end{array}$ & $\begin{array}{r}.7 \\
.7 \\
\text { nd }\end{array}$ & $\begin{array}{l}<.1 \\
<.1 \\
\text { nd }\end{array}$ & $\begin{array}{c}23.9 \\
23.8 \\
\text { nd }\end{array}$ \\
\hline 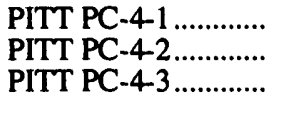 & $\begin{array}{r}.6 \\
.4 \\
\text { nd }\end{array}$ & $\begin{array}{r}.6 \\
.6 \\
\text { nd }\end{array}$ & $\begin{array}{c}20.3 \\
20.0 \\
\text { nd }\end{array}$ & $\begin{array}{r}45.4 \\
45.8 \\
\text { nd }\end{array}$ & $\begin{array}{r}.2 \\
.2 \\
\text { nd }\end{array}$ & $\begin{array}{l}2.0 \\
1.9 \\
\text { nd }\end{array}$ & $\begin{array}{l}1.5 \\
1.5 \\
\text { nd }\end{array}$ & $\begin{array}{l}3.1 \\
3.0 \\
\text { nd }\end{array}$ & $\begin{array}{l}1.1 \\
1.1 \\
\text { nd }\end{array}$ & $\begin{array}{l}<.1 \\
<.1 \\
\text { nd }\end{array}$ & $\begin{array}{c}22.6 \\
22.2 \\
\text { nd }\end{array}$ \\
\hline $\begin{array}{l}\text { POC PC-5-1 } \\
\text { POC PC-5-2 } \\
\text { POC PC................... }\end{array}$ & $\begin{array}{l}1.9 \\
1.8 \\
\text { nd }\end{array}$ & $\begin{array}{l}2.1 \\
2.1 \\
\text { nd }\end{array}$ & $\begin{array}{c}19.6 \\
19.5 \\
\text { nd }\end{array}$ & $\begin{array}{c}32.7 \\
32.2 \\
\text { nd }\end{array}$ & $\begin{array}{l}1 \\
.1 \\
\text { nd }\end{array}$ & $\begin{array}{l}6.6 \\
6.0 \\
\text { nd }\end{array}$ & $\begin{array}{r}.7 \\
.7 \\
\text { nd }\end{array}$ & $\begin{array}{c}11.7 \\
11.7 \\
\text { nd }\end{array}$ & $\begin{array}{l}1.2 \\
1.2 \\
\text { nd }\end{array}$ & $\begin{array}{l}<.1 \\
<.1 \\
\text { nd }\end{array}$ & $\begin{array}{c}14.0 \\
14.1 \\
\text { nd }\end{array}$ \\
\hline 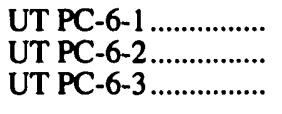 & $\begin{array}{l}3.8 \\
\text { nd } \\
\text { nd }\end{array}$ & $\begin{array}{l}1.4 \\
\text { nd } \\
\text { nd }\end{array}$ & $\begin{array}{l}15.2 \\
\text { nd } \\
\text { nd }\end{array}$ & $\begin{array}{c}41.5 \\
\text { nd } \\
\text { nd }\end{array}$ & $\begin{array}{l}.1 \\
\text { nd } \\
\text { nd }\end{array}$ & $\begin{array}{l}8.3 \\
\text { nd } \\
\text { nd }\end{array}$ & $\begin{array}{l}.6 \\
\text { nd } \\
\text { nd }\end{array}$ & $\begin{array}{c}12.2 \\
\text { nd } \\
\text { nd }\end{array}$ & $\begin{array}{l}.8 \\
\text { nd } \\
\text { nd }\end{array}$ & $\begin{array}{l}<: 1 \\
\text { nd } \\
\text { nd }\end{array}$ & $\begin{array}{l}9.0 \\
\text { nd } \\
\text { nd }\end{array}$ \\
\hline $\begin{array}{l}\text { WV PC- } 7-1 \ldots \ldots \ldots \ldots . . \\
\text { WV PC- }-2 \ldots \ldots \ldots \ldots \ldots . . \\
\text { WV PC- } 7-3 \ldots \ldots \ldots \ldots \ldots\end{array}$ & $\begin{array}{l}.3 \\
\text { nd } \\
\text { nd }\end{array}$ & $\begin{array}{l}.7 \\
\text { nd } \\
\text { nd }\end{array}$ & $\begin{array}{c}30.8 \\
\text { nd } \\
\text { nd }\end{array}$ & $\begin{array}{c}54.0 \\
\text { nd } \\
\text { nd }\end{array}$ & $\begin{array}{l}.1 \\
\text { nd } \\
\text { nd }\end{array}$ & $\begin{array}{l}\text { nd } \\
\text { nd }\end{array}$ & $\begin{array}{l}2.9 \\
\text { nd } \\
\text { nd }\end{array}$ & $\begin{array}{l}\text { nd } \\
\text { nd }\end{array}$ & $\begin{array}{l}2.1 \\
\text { nd } \\
\text { nd }\end{array}$ & $\begin{array}{l}<.1 \\
\text { nd } \\
\text { nd }\end{array}$ & $\begin{array}{l}2.8 \\
\text { nd } \\
\text { nd }\end{array}$ \\
\hline 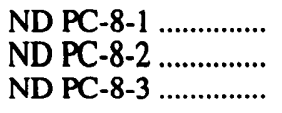 & $\begin{array}{l}7.1 \\
\text { nd } \\
\text { nd }\end{array}$ & $\begin{array}{l}7.3 \\
\text { nd } \\
\text { nd }\end{array}$ & $\begin{array}{l}9.0 \\
\text { nd } \\
\text { nd }\end{array}$ & $\begin{array}{l}17: 3 \\
\text { nd } \\
\text { nd }\end{array}$ & $\begin{array}{l}.4 \\
\text { nd } \\
\text { nd }\end{array}$ & $\begin{array}{l}20.5 \\
\text { nd } \\
\text { nd }\end{array}$ & $\begin{array}{l}.4 \\
\text { nd } \\
\text { nd }\end{array}$ & $\begin{array}{l}22.6 \\
\text { nd } \\
\text { nd }\end{array}$ & $\begin{array}{l}\text {.3 } \\
\text { nd } \\
\text { nd }\end{array}$ & $\begin{array}{l}1 \\
\text { nd } \\
\text { nd }\end{array}$ & $\begin{array}{l}6.7 \\
\text { nd } \\
\text { nd }\end{array}$ \\
\hline
\end{tabular}

cellulose for 10 minutes on a shaker mill and subsequently pressing the mixture against a fibrous cellulose backing at $276 \mathrm{MPa}$ for approximately 30 seconds (Johnson and others, 1989).

The difficulties experienced in the analysis of whole coals by EDXRF also apply for WDXRF. Reliable wholecoal standard reference materials are scarce. Because these standards are not commercially available, synthetic standards as well as coal samples characterized by other laboratories were used. Only three NIST coal standards were used in this study: NIST 1633, 1633a, and 1635 (NBS, 1975, 1979 , and 1978b). Spiked graphite samples with varying concentrations of chlorine and phosphorus served as the synthetic whole-coal standards. All standards were prepared identically to those for the whole-coal samples. Intensity measurements for chlorine and phosphorus were made on a Diano XRD-8300 wavelength-dispersive X-ray fluorescence spectrometer.

Calibration graphs were constructed by plotting the analyte intensity versus the known concentration for a set of standards. The intensities for chlorine and phosphorus in the whole-coal samples were then used to calculate chlorine and phosphorus concentrations from the regression curves.

\section{RESULTS AND DISCUSSION}

In this study, eight Argonne Premium Coal samples were analyzed by EDXRF and WDXRF spectrometry. Determinations of major oxides in coal ash are detailed in table 2; trace elements in coal ash in table 3; chlorine and phosphorus oxide in whole coal in table 4; and trace elements in whole coal in table 5. The precision and accuracy for the analysis of coal ash samples by EDXRF and WDXRF closely approximate the precision and accuracy for the analysis of silicates. A study by Johnson and others (1989) estimated an average relative difference of \pm 2 to \pm 5 percent for WDXRF determinations of major elements $(\mathrm{Na}$, $\mathrm{Mg}, \mathrm{Al}, \mathrm{Si}, \mathrm{P}, \mathrm{S}, \mathrm{K}, \mathrm{Ca}, \mathrm{Ti}, \mathrm{Mn}$, and $\mathrm{Fe}$ ) in coal ash samples. Trace-element determinations $(\mathrm{Cr}, \mathrm{Ni}, \mathrm{Cu}, \mathrm{Zn}, \mathrm{Rb}, \mathrm{Sr}, \mathrm{Y}$, $\mathrm{Zr}, \mathrm{Nb}, \mathrm{Ba}, \mathrm{La}$, and $\mathrm{Ce}$ ) by EDXRF for silicate rocks were estimated to have an accuracy of $< \pm 5$ percent for the ratiocalibration graph method (Johnson, 1984). This level of accuracy is also expected for EDXRF trace-element determinations on coal ash.

The precision and accuracy of the EDXRF and WDXRF analyses of whole-coal samples were more difficult to estimate, since a wide range of acceptable standards 
Table 3. Trace-element concentrations (in micrograms per gram, $\mu \mathrm{g} / \mathrm{g}$ ) in coal ash determined by EDXRF (reported on an ash basis). [nd, not determined]

\begin{tabular}{|c|c|c|c|c|c|c|c|c|c|c|c|c|}
\hline Coal sample & $\mathrm{Cr}$ & $\mathrm{Ni}$ & $\mathrm{Cu}$ & $\mathrm{Zn}$ & $\mathbf{R b}$ & $\mathrm{Sr}$ & $\mathbf{Y}$ & $\mathrm{Zr}$ & $\mathrm{Nb}$ & $\mathrm{Ba}$ & La & $\mathrm{Ce}$ \\
\hline 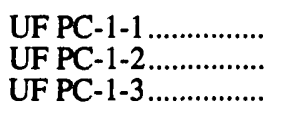 & $\begin{array}{l}186 \\
196 \\
196\end{array}$ & $\begin{array}{r}104 \\
118 \\
84\end{array}$ & $\begin{array}{l}146 \\
152 \\
158\end{array}$ & $\begin{array}{l}162 \\
142 \\
150\end{array}$ & $\begin{array}{l}160 \\
154 \\
158\end{array}$ & $\begin{array}{l}440 \\
450 \\
450\end{array}$ & $\begin{array}{l}74 \\
72 \\
84\end{array}$ & $\begin{array}{l}205 \\
196 \\
205\end{array}$ & $\begin{array}{l}20 \\
16 \\
20\end{array}$ & $\begin{array}{l}380 \\
405 \\
370\end{array}$ & $\begin{array}{l}52 \\
60 \\
70\end{array}$ & $\begin{array}{l}112 \\
136 \\
130\end{array}$ \\
\hline $\begin{array}{l}\text { WY PC-2-1 } \\
\text { WY PC-2-2 ................ } \\
\text { WY PC-2-3 .............. }\end{array}$ & $\begin{array}{r}86 \\
96 \\
108\end{array}$ & $\begin{array}{l}50 \\
46 \\
44\end{array}$ & $\begin{array}{l}142 \\
158 \\
154\end{array}$ & $\begin{array}{l}114 \\
130 \\
130\end{array}$ & $\begin{array}{l}40 \\
40 \\
44\end{array}$ & $\begin{array}{l}3,100 \\
3,000 \\
3,100\end{array}$ & $\begin{array}{l}40 \\
42 \\
44\end{array}$ & $\begin{array}{l}260 \\
275 \\
265\end{array}$ & $\begin{array}{l}14 \\
12 \\
10\end{array}$ & $\begin{array}{l}3,200 \\
3,300 \\
3,100\end{array}$ & $\begin{array}{l}<30 \\
<30 \\
<30\end{array}$ & $\begin{array}{r}72 \\
50 \\
<30\end{array}$ \\
\hline 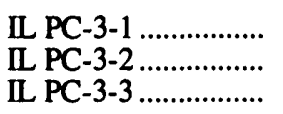 & $\begin{array}{l}265 \\
265 \\
270\end{array}$ & $\begin{array}{r}88 \\
122 \\
120\end{array}$ & $\begin{array}{l}66 \\
58 \\
54\end{array}$ & $\begin{array}{l}984 \\
737 \\
750\end{array}$ & $\begin{array}{l}90 \\
90 \\
92\end{array}$ & $\begin{array}{l}188 \\
178 \\
188\end{array}$ & $\begin{array}{l}30 \\
20 \\
26\end{array}$ & $\begin{array}{l}146 \\
130 \\
136\end{array}$ & $\begin{array}{r}12 \\
<10 \\
14\end{array}$ & $\begin{array}{l}465 \\
460 \\
455\end{array}$ & $\begin{array}{l}<30 \\
<30 \\
<30\end{array}$ & $\begin{array}{l}42 \\
52 \\
40\end{array}$ \\
\hline $\begin{array}{l}\text { PITT PC-4-1 ........... } \\
\text { PITT PC-4-2 .......... } \\
\text { PITT PC-4-3 ........... }\end{array}$ & $\begin{array}{l}200 \\
190 \\
195\end{array}$ & $\begin{array}{r}98 \\
96 \\
112\end{array}$ & $\begin{array}{l}70 \\
66 \\
66\end{array}$ & $\begin{array}{l}92 \\
92 \\
88\end{array}$ & $\begin{array}{r}102 \\
94 \\
100\end{array}$ & $\begin{array}{l}760 \\
740 \\
710\end{array}$ & $\begin{array}{l}56 \\
56 \\
48\end{array}$ & $\begin{array}{l}225 \\
230 \\
215\end{array}$ & $\begin{array}{l}22 \\
20 \\
20\end{array}$ & $\begin{array}{l}370 \\
410 \\
385\end{array}$ & $\begin{array}{r}<30 \\
50 \\
46\end{array}$ & $\begin{array}{r}80 \\
108 \\
104\end{array}$ \\
\hline $\begin{array}{l}\text { POC PC-5-1 ........... } \\
\text { POC PC-5-2 ........... } \\
\text { POC PC-5-3 ............. }\end{array}$ & $\begin{array}{l}235 \\
225 \\
235\end{array}$ & $\begin{array}{l}132 \\
146 \\
150\end{array}$ & $\begin{array}{l}240 \\
245 \\
225\end{array}$ & $\begin{array}{r}82 \\
100 \\
88\end{array}$ & $\begin{array}{l}50 \\
40 \\
42\end{array}$ & $\begin{array}{l}2,100 \\
2,100 \\
2,100\end{array}$ & $\begin{array}{l}134 \\
126 \\
130\end{array}$ & $\begin{array}{l}320 \\
315 \\
320\end{array}$ & $\begin{array}{l}16 \\
16 \\
16\end{array}$ & $\begin{array}{l}3,200 \\
3,600 \\
3,500\end{array}$ & $\begin{array}{r}3 \\
50 \\
44\end{array}$ & $\begin{array}{l}100 \\
162 \\
168\end{array}$ \\
\hline 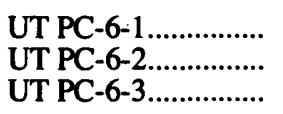 & $\begin{array}{l}\text { nd } \\
\text { nd } \\
\text { nd }\end{array}$ & $\begin{array}{l}\text { nd } \\
\text { nd } \\
\text { nd }\end{array}$ & $\begin{array}{l}\text { nd } \\
\text { nd } \\
\text { nd }\end{array}$ & $\begin{array}{l}\text { nd } \\
\text { nd } \\
\text { nd }\end{array}$ & $\begin{array}{l}\text { nd } \\
\text { nd } \\
\text { nd }\end{array}$ & $\begin{array}{l}\text { nd } \\
\text { nd } \\
\text { nd }\end{array}$ & $\begin{array}{l}\text { nd } \\
\text { nd } \\
\text { nd }\end{array}$ & $\begin{array}{l}\text { nd } \\
\text { nd } \\
\text { nd }\end{array}$ & $\begin{array}{l}\text { nd } \\
\text { nd } \\
\text { nd }\end{array}$ & $\begin{array}{l}\text { nd } \\
\text { nd } \\
\text { nd }\end{array}$ & $\begin{array}{l}\text { nd } \\
\text { nd } \\
\text { nd }\end{array}$ & $\begin{array}{l}\text { nd } \\
\text { nd } \\
\text { nd }\end{array}$ \\
\hline $\begin{array}{l}\text { WV PC-7-1 } \\
\text { WV PC-7 } 2 \ldots \ldots \ldots \ldots . . . . . \\
\text { WV PC-7-3 ............... }\end{array}$ & $\begin{array}{l}238 \\
234 \\
237\end{array}$ & $\begin{array}{l}91 \\
83 \\
87\end{array}$ & $\begin{array}{l}130 \\
115 \\
120\end{array}$ & $\begin{array}{l}64 \\
57 \\
59\end{array}$ & $\begin{array}{l}218 \\
232 \\
224\end{array}$ & $\begin{array}{l}393 \\
402 \\
411\end{array}$ & $\begin{array}{r}110 \\
99 \\
118\end{array}$ & $\begin{array}{l}412 \\
411 \\
421\end{array}$ & $\begin{array}{l}40 \\
43 \\
46\end{array}$ & $\begin{array}{l}567 \\
577 \\
552\end{array}$ & $\begin{array}{l}75 \\
91 \\
96\end{array}$ & $\begin{array}{l}145 \\
163 \\
154\end{array}$ \\
\hline $\begin{array}{l}\text { ND PC- } 8-1 \ldots \ldots \ldots \ldots . . \\
\text { ND PC- } 8-2 \ldots \ldots \ldots \ldots \ldots \\
\text { ND PC- } 8-3 \ldots \ldots \ldots \ldots \ldots .\end{array}$ & $\begin{array}{l}26 \\
28 \\
29\end{array}$ & $\begin{array}{l}25 \\
17 \\
19\end{array}$ & $\begin{array}{l}36 \\
35 \\
34\end{array}$ & $\begin{array}{l}61 \\
54 \\
55\end{array}$ & $\begin{array}{l}\text { nd } \\
\text { nd } \\
\text { nd }\end{array}$ & $\begin{array}{l}6,700 \\
6,700 \\
6,700\end{array}$ & $\begin{array}{l}\text { nd } \\
\text { nd } \\
\text { nd }\end{array}$ & $\begin{array}{l}68 \\
74 \\
47\end{array}$ & $\begin{array}{l}<10 \\
<10 \\
<10\end{array}$ & $\begin{array}{l}5,000 \\
4,900 \\
4,700\end{array}$ & $\begin{array}{l}\text { nd } \\
\text { nd } \\
\text { nd }\end{array}$ & $\begin{array}{l}\text { nd } \\
\text { nd } \\
\text { nd }\end{array}$ \\
\hline
\end{tabular}

Table 4. Chlorine and phosphorus oxide concentrations (in weight percent) in whole coal determined by WDXRF.

\begin{tabular}{|c|c|c|}
\hline Coal sample & $\mathrm{Cl}$ & $\mathrm{P}_{2} \mathrm{O}_{5}$ \\
\hline 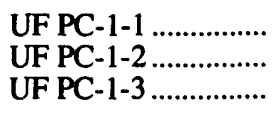 & $\begin{array}{r}0.15 \\
.14 \\
.15\end{array}$ & $\begin{array}{l}<0.01 \\
<.01 \\
<.01\end{array}$ \\
\hline 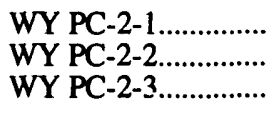 & $\begin{array}{l}<.01 \\
<.01 \\
<.01\end{array}$ & $\begin{array}{l}.06 \\
.05 \\
.06\end{array}$ \\
\hline 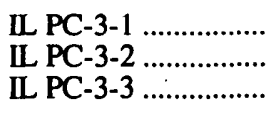 & $\begin{array}{l}.05 \\
.05 \\
.06\end{array}$ & $\begin{array}{l}<.01 \\
<.01 \\
<.01\end{array}$ \\
\hline $\begin{array}{l}\text { PITT PC-4-1 } \\
\text { PITT PC-4-2............ } \\
\text { PITT PC-4-3............ }\end{array}$ & $\begin{array}{l}.06 \\
.06 \\
.07\end{array}$ & $\begin{array}{l}.02 \\
.02 \\
.02\end{array}$ \\
\hline
\end{tabular}

\begin{tabular}{|c|c|c|}
\hline Coal sample & $\mathrm{Cl}$ & $\mathrm{P}_{2} \mathrm{O}_{5}$ \\
\hline $\begin{array}{l}\text { POC PC-5-1 } \\
\text { POC PC-5-2 } \\
\text { POC PC-5 } 5 \ldots \ldots \ldots \ldots \\
\end{array}$ & $\begin{array}{r}0.16 \\
.16 \\
.16\end{array}$ & $\begin{array}{l}<0.01 \\
<.01 \\
<.01\end{array}$ \\
\hline 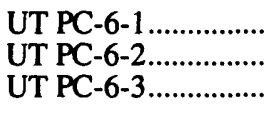 & $\begin{array}{l}<.01 \\
<.01 \\
<.01\end{array}$ & $\begin{array}{l}<.01 \\
<.01 \\
<.01\end{array}$ \\
\hline 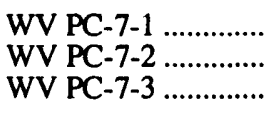 & $\begin{array}{l}.04 \\
.04 \\
.05\end{array}$ & $\begin{array}{l}<.01 \\
<.01 \\
<.01\end{array}$ \\
\hline $\begin{array}{l}\text { ND PC-8-1 } \\
\text { ND PC-8 } 2 \ldots \ldots \ldots \ldots \ldots \\
\text { ND PC- } 8-3 \ldots \ldots \ldots \ldots \ldots \ldots \\
\end{array}$ & $\begin{array}{l}<.01 \\
<.01 \\
<.01\end{array}$ & $\begin{array}{l}.04 \\
.04 \\
.04\end{array}$ \\
\hline
\end{tabular}


Table 5. Trace-element concentrations (in micrograms per gram, $\mu \mathrm{g} / \mathrm{g}$ ) in whole coal determined by EDXRF.

[nd, not determined]

\begin{tabular}{|c|c|c|c|c|c|c|c|c|c|c|c|c|}
\hline Coal sample & $\mathrm{Cr}$ & $\mathrm{Ni}$ & $\mathrm{Cu}$ & $\mathrm{Zn}$ & $\mathbf{R b}$ & Sr & $\mathbf{Y}$ & $\mathrm{Zr}$ & $\mathrm{Nb}$ & $\mathrm{Ba}$ & $\mathrm{La}$ & $\mathrm{Ce}$ \\
\hline 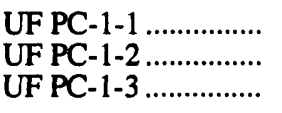 & $\begin{array}{l}15 \\
23 \\
19\end{array}$ & $\begin{array}{l}27 \\
22 \\
21\end{array}$ & $\begin{array}{l}20 \\
18 \\
17\end{array}$ & $\begin{array}{l}35 \\
32 \\
31\end{array}$ & $\begin{array}{l}23 \\
21 \\
20\end{array}$ & $\begin{array}{l}61 \\
63 \\
61\end{array}$ & $\begin{array}{l}\text { nd } \\
\text { nd } \\
\text { nd }\end{array}$ & $\begin{array}{l}24 \\
22 \\
24\end{array}$ & $\begin{array}{l}\text { nd } \\
\text { nd } \\
\text { nd }\end{array}$ & $\begin{array}{l}54 \\
68 \\
59\end{array}$ & $\begin{array}{r}31 \\
9 \\
9\end{array}$ & $\begin{array}{l}27 \\
46 \\
48\end{array}$ \\
\hline 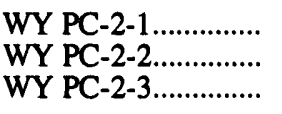 & $\begin{array}{r}3 \\
5 \\
\text { nd }\end{array}$ & $\begin{array}{l}9 \\
7 \\
8\end{array}$ & $\begin{array}{l}18 \\
17 \\
17\end{array}$ & $\begin{array}{l}26 \\
29 \\
21\end{array}$ & $\begin{array}{l}14 \\
14 \\
11\end{array}$ & $\begin{array}{l}292 \\
300 \\
291\end{array}$ & $\begin{array}{l}\text { nd } \\
\text { nd } \\
\text { nd }\end{array}$ & $\begin{array}{l}19 \\
21 \\
17\end{array}$ & $\begin{array}{l}\text { nd } \\
\text { nd } \\
\text { nd }\end{array}$ & $\begin{array}{l}404 \\
407 \\
415\end{array}$ & $\begin{array}{r}4 \\
4 \\
11\end{array}$ & $\begin{array}{l}18 \\
21 \\
35\end{array}$ \\
\hline 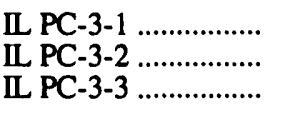 & $\begin{array}{l}29 \\
36 \\
41\end{array}$ & $\begin{array}{l}33 \\
30 \\
33\end{array}$ & $\begin{array}{l}15 \\
13 \\
15\end{array}$ & $\begin{array}{l}137 \\
105 \\
186\end{array}$ & $\begin{array}{l}22 \\
17 \\
21\end{array}$ & $\begin{array}{l}33 \\
30 \\
35\end{array}$ & $\begin{array}{l}\text { nd } \\
\text { nd } \\
\text { nd }\end{array}$ & $\begin{array}{l}24 \\
22 \\
24\end{array}$ & $\begin{array}{l}\text { nd } \\
\text { nd } \\
\text { nd }\end{array}$ & $\begin{array}{l}112 \\
122 \\
129\end{array}$ & $\begin{array}{l}16 \\
15 \\
15\end{array}$ & $\begin{array}{l}23 \\
39 \\
64\end{array}$ \\
\hline $\begin{array}{l}\text { PITT PC-4-1 ............ } \\
\text { PITT PC-42 ........... } \\
\text { PITT PC-4-3............ }\end{array}$ & $\begin{array}{r}6 \\
10 \\
9\end{array}$ & $\begin{array}{l}17 \\
11 \\
15\end{array}$ & $\begin{array}{r}10 \\
9 \\
10\end{array}$ & $\begin{array}{l}17 \\
14 \\
15\end{array}$ & $\begin{array}{l}8 \\
8 \\
8\end{array}$ & $\begin{array}{l}59 \\
61 \\
69\end{array}$ & $\begin{array}{l}\text { nd } \\
\text { nd } \\
\text { nd }\end{array}$ & $\begin{array}{l}15 \\
17 \\
18\end{array}$ & $\begin{array}{l}\text { nd } \\
\text { nd } \\
\text { nd }\end{array}$ & $\begin{array}{l}46 \\
22 \\
19\end{array}$ & $\begin{array}{r}23 \\
1 \\
2\end{array}$ & $\begin{array}{r}19 \\
25 \\
6\end{array}$ \\
\hline 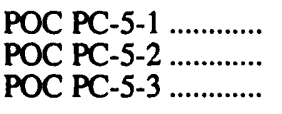 & $\begin{array}{l}5 \\
7 \\
4\end{array}$ & $\begin{array}{r}11 \\
9 \\
12\end{array}$ & $\begin{array}{l}16 \\
16 \\
19\end{array}$ & $\begin{array}{l}14 \\
14 \\
15\end{array}$ & $\begin{array}{l}5 \\
4 \\
5\end{array}$ & $\begin{array}{l}86 \\
77 \\
93\end{array}$ & $\begin{array}{l}\text { nd } \\
\text { nd } \\
\text { nd }\end{array}$ & $\begin{array}{r}10 \\
8 \\
11\end{array}$ & $\begin{array}{l}\text { nd } \\
\text { nd } \\
\text { nd }\end{array}$ & $\begin{array}{l}134 \\
124 \\
164\end{array}$ & $\begin{array}{r}1 \\
4 \\
10\end{array}$ & $\begin{array}{r}4 \\
19 \\
8\end{array}$ \\
\hline $\begin{array}{l}\text { UT PC-6-1 } \ldots \ldots \ldots \ldots \ldots . . \\
\text { UT PC-6-2 ............... } \\
\text { UT PC-6-3 ............... }\end{array}$ & $\begin{array}{l}<10 \\
<10 \\
<10\end{array}$ & $\begin{array}{l}5 \\
5 \\
5\end{array}$ & $\begin{array}{l}8 \\
8 \\
8\end{array}$ & $\begin{array}{l}<2 \\
<2 \\
<2\end{array}$ & $\begin{array}{l}3 \\
2 \\
3\end{array}$ & $\begin{array}{l}58 \\
65 \\
66\end{array}$ & $\begin{array}{l}2 \\
<2 \\
<2\end{array}$ & $\begin{array}{l}20 \\
17 \\
16\end{array}$ & $\begin{array}{l}<10 \\
<10 \\
<10\end{array}$ & $\begin{array}{l}28 \\
32 \\
28\end{array}$ & $\begin{array}{r}9 \\
9 \\
11\end{array}$ & $\begin{array}{l}20 \\
13 \\
12\end{array}$ \\
\hline $\begin{array}{l}\text { WV PC-7-1........... } \\
\text { WV PC-7-2............ } \\
\text { WV PC-7-3........... }\end{array}$ & $\begin{array}{l}50 \\
48 \\
48\end{array}$ & $\begin{array}{l}17 \\
18 \\
19\end{array}$ & $\begin{array}{l}30 \\
30 \\
32\end{array}$ & $\begin{array}{r}9 \\
10 \\
10\end{array}$ & $\begin{array}{l}43 \\
43 \\
40\end{array}$ & $\begin{array}{l}87 \\
87 \\
83\end{array}$ & $\begin{array}{l}19 \\
20 \\
17\end{array}$ & $\begin{array}{l}106 \\
102 \\
101\end{array}$ & $\begin{array}{r}13 \\
<10 \\
13\end{array}$ & $\begin{array}{l}230 \\
202 \\
200\end{array}$ & $\begin{array}{l}15 \\
18 \\
14\end{array}$ & $\begin{array}{l}64 \\
54 \\
48\end{array}$ \\
\hline $\begin{array}{l}\text { ND PC-8-1 } \ldots \ldots \ldots \ldots \ldots \\
\text { ND PC-8 }-2 \ldots \ldots \ldots \ldots \ldots \\
\text { ND PC-8-3 } \ldots \ldots \ldots \ldots \ldots . .\end{array}$ & $\begin{array}{l}<10 \\
<10 \\
<10\end{array}$ & $\begin{array}{r}4 \\
10 \\
4\end{array}$ & $\begin{array}{r}8 \\
10 \\
10\end{array}$ & $\begin{array}{l}5 \\
4 \\
6\end{array}$ & $\begin{array}{l}4 \\
5 \\
3\end{array}$ & $\begin{array}{l}800 \\
802 \\
753\end{array}$ & $\begin{array}{l}<2 \\
<2 \\
<2\end{array}$ & $\begin{array}{l}20 \\
19 \\
17\end{array}$ & $\begin{array}{l}<10 \\
<10 \\
<10\end{array}$ & $\begin{array}{l}1000 \\
1040 \\
1060\end{array}$ & $\begin{array}{r}8 \\
6 \\
10\end{array}$ & $\begin{array}{l}21 \\
19 \\
17\end{array}$ \\
\hline
\end{tabular}

was not available. However, Johnson and others (1989) estimated the average relative difference for chlorine and phosphorus oxide determinations on whole coals to be \pm 10 percent. Trace-element $(\mathrm{Cr}, \mathrm{Ni}, \mathrm{Cu}, \mathrm{Zn}, \mathrm{Rb}, \mathrm{Sr}, \mathrm{Y}, \mathrm{Zr}, \mathrm{Nb}$, $\mathrm{Ba}, \mathrm{La}$, and $\mathrm{Ce}$ ) determinations on the whole coal by EDXRF generally show close agreement ( \pm 10 percent) between replicate samples. A wide variance was noted, however, when the whole-coal trace-element results were compared with the results obtained on the coal ash. Further investigation is needed to evaluate more clearly the accuracy of the matrix correction method for whole coals.

\section{REFERENCES}

Abbey, Sydney, 1983, Studies in "standard samples" of silicate rocks and minerals, 1969-1982: Canada Geological Survey Paper 83-15, $114 \mathrm{p}$.

American Society for Testing and Materials (ASTM), 1996, ASTM Designation D 3174-93, Standard test method for ash in the analysis sample of coal and coke from coal: 1996 Annual Book of ASTM Standards, v. 05.05, Gaseous fuels; Coal and coke, p. 291-294.
Evans, J.R., and Jackson, J.C., 1989, Determination of tin in silicate rocks by energy-dispersive $\mathrm{X}$-ray fluorescence spectrometry: X-Ray Spectrometry, v. 18, p. 139-141.

Johnson, R.G., 1984, Trace element analysis of silicates by means of energy-dispersive X-ray spectrometry: X-Ray Spectrometry, v. 13 , no. 2 , p. $64-68$.

Johnson, R.G., and Fleming, S.L., II, 1987, Energy-dispersive Xray fluorescence analysis of massive sulfides using fundamental influence coefficients: X-Ray Spectrometry, v. 16, p. 167-170.

Johnson, R.G., Palmer, C.A., Dennen, K.O., and Hearn, P.P., 1986, Energy-dispersive $\mathrm{X}$-ray fluorescence analysis of trace elements in carbonate rocks: Applied Spectroscopy, v. 40, no. 1, p. 76-79.

Johnson, R.G., Sellers, G.A., and Fleming, S.L., II, 1989, The determination of major and minor elements in coal ash and of chlorine and phosphorus in whole coal by $\mathrm{X}$-ray fluorescence spectrometry, in Golightly, D.W., and Simon, F.O., eds., Methods for sampling and inorganic analysis of coal: U.S. Geological Survey Bulletin 1823, p. 35-39.

Kuhn, J.K., Harfst, W.F., and Shimp, N.F., 1975, X-ray fluorescence analysis of whole coal, in Babu, S.P., ed., Trace elements in fuel: Washington, D.C., American Chemical Society, p. 66-73. 
National Bureau of Standards, 1975, National Bureau of Standards certificate of analysis, standard reference material 1633, trace elements in coal fly ash: Washington, D.C., National Bureau of Standards, 2 p.

1978a, National Bureau of Standards certificate of analysis, standard reference material 1632a, trace elements in coal (bituminous): Washington, D.C., National Bureau of Standards, 2 p.

1978b, National Bureau of Standards certificate of analysis, standard reference material 1635 , trace elements in coal (subbituminous): Washington, D.C., National Bureau of Standards, 2 p.

1979, National Bureau of Standards certificate of analysis, standard reference material 1633a, trace elements in coal fly ash: Washington, D.C., National Bureau of Standards, 2 p.

1985, National Bureau of Standards certificate of analysis, standard reference material $1632 \mathrm{~b}$, trace elements in coal (bituminous): Gaithersburg, Md., National Bureau of Standards, $5 \mathrm{p}$.

Norrish, K., and Hutton, J.T., 1969, An accurate X-ray spectrographic method for the analysis of a wide range of geological samples: Geochimica et Cosmochimica Acta, v. 33, no. 4, p. 431-453.

Rose, H.J., Jr., Adler, Isidore, and Flanagan, F.J., 1963, X-ray fluorescence analysis of light elements in rocks and minerals: Applied Spectroscopy, v. 17, no. 4, p. 81-85.

Rousseau, R.M., 1984a, Fundamental algorithm between concentration and intensity in XRF analysis. 1-Theory: X-Ray Spectrometry, v. 13, no. 3, p. 115-120.

1984b, Fundamental algorithm between concentration and intensity in XRF analysis. 2-Practical application: X-Ray Spectrometry, v. 13, no. 3, p. 121-125.

Sherman, J., 1959, Research note-Simplification of a formula in the correlation of fluorescent $\mathrm{X}$-ray intensities from mixtures: Spectrochimica Acta, v. 15, no. 6, p. 466-470. 


\title{
Determination of 29 Elements in 8 Argonne Premium Coal Samples by Instrumental Neutron Activation Analysis
}

\author{
By Curtis A. Palmer
}

\begin{abstract}
Twenty-nine elements have been determined in triplicate splits of the eight Argonne Premium Coal samples by instrumental neutron activation analysis. Data for control samples NIST (National Institute of Standards and Technology) 1633 (fly ash) and NIST 1632 b (bituminous coal) are also reported. The factors that could lead to errors in analysis of these samples, such as spectral overlaps, low sensitivity, and multiple sources of interfering nuclear reactions, are discussed.
\end{abstract}

\section{INTRODUCTION}

The U.S. Geological Survey (for example, Zubovic and others, 1979, 1980; Oman and others, 1981; Currens and others, 1986, 1987) and other laboratories (for example, Gluskoter and others, 1977) have used instrumental neutron activation analysis (INAA) for the determination of major, minor, and trace elements in thousands of coal samples. The application of INAA for the analysis of coal has been described in several papers (for example, Block and Dams, 1973; Ondov and others, 1975; Rowe and Steinnes, 1977a,b; Swaine, 1985; Palmer and Baedecker, 1989). The analysis of coal by INAA is especially useful because determinations are made on the whole coal in contrast to other techniques in which the ash is used as the sample matrix. Therefore, INAA can be used to measure elements that might be volatilized during ashing, such as bromine. All elements are determined on the same sample split so that element ratios used in understanding geochemical environments are not affected by inhomogeneities in a coal sample. In addition, INAA has very low detection limits for many elements, can be easily automated, and provides precise data for many major, minor, and trace elements.

\section{ACKNOWLEDGMENTS}

The author would like to thank Jeff Grossman and Phil Baedecker for help with the derivation of the fission product correction formulas, Mike Pickering for assistance in counting the samples, and Jean Kane, Phil Baedecker, and Frank Walthall for suggestions to the manuscript.

\section{EXPERIMENTAL}

Three splits of approximately $500 \mathrm{mg}$ of each of the eight Argonne Premium Coal samples were weighed and heat sealed in $1.5-\mathrm{cm}^{3}$ polyethylene vials. These samples were irradiated for 8 hours in the TRIGA research reactor facility of the U.S. Geological Survey in Denver, Colo., at a neutron flux of $3 \times 10^{12}$ neutrons $/ \mathrm{cm}^{2} \mathrm{sec}$. After a delay of 3 days to eliminate or reduce short-lived activity, the samples were shipped by overnight delivery to laboratories in Reston; Va., for gamma-ray counting.

The samples were counted at three different times on high-resolution coaxial germanium and germanium (lithium) detectors for gamma-ray spectroscopy. The first count was started approximately 4 days after irradiation. A second count was started at 17 days after irradiation after allowing the short-lived activities (especially ${ }^{24} \mathrm{Na}$, half-life $=15$ hours) to decay, and then a third count was begun approximately 2 months after irradiation to obtain higher precision on the measurement of the long-lived radionuclides. The gamma-ray detectors were coupled to multichannel pulseheight analyzers, which are capable of dividing the spectrum into 4,096 energy increments or channels. An automatic sample changer similar to that described by Massoni and others (1973) was used to change the samples. All spectra were processed by using the computer program SPECTRA (Baedecker and Grossman, 1989, 1994).

\section{SAMPLES AND STANDARDS}

The eight Argonne National Laboratory Premium Coal samples used in this study have been described previously (Vorres, 1990). The convention for sample identification is the same as described by Palmer in the Introduction of this volume. Three multiple-element standards, NIST (National Institute of Standards and Technology) 1632a, NIST 1633a, 
Table 1. Comparison of concentrations determined (in micrograms per gram, $\mu \mathrm{g} / \mathrm{g}$ ) from this study with literature values.

[Concentrations in this study were determined by instrumental neutron activation analysis (INAA). Blank, no values available from listed source]

\begin{tabular}{|c|c|c|c|c|}
\hline \multirow{2}{*}{ Element } & \multicolumn{2}{|c|}{ NIST 1633, fly ash } & \multicolumn{2}{|c|}{ NIST $1632 \mathrm{~b}$, bituminous coal } \\
\hline & This study & Literature $^{1}$ & This study & Literature $^{2}$ \\
\hline 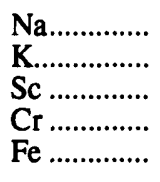 & $\begin{array}{c}3,060 \pm 64 \\
16,000 \pm 640 \\
27.3 \pm 0.27 \\
113.4 \pm 8.6 \\
62,600 \pm 630\end{array}$ & $\begin{array}{c}3,200 \pm 400 \\
16,100 \pm 1,500 \\
27 \pm 1 \\
127 \pm 6 \\
62,000 \pm 3,000\end{array}$ & $\begin{array}{c}513 \pm 5 \\
740 \pm 37 \\
2.060 \pm 0.02 \\
10.4 \pm 0.3 \\
7,780 \pm 160\end{array}$ & $\begin{array}{c}515 \pm 11 \\
748 \pm 28 \\
1.9 \\
11 \\
7,590 \pm 450\end{array}$ \\
\hline 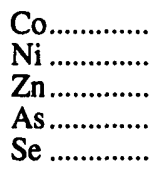 & $\begin{array}{c}40.8 \pm 2.0 \\
92 \pm 10 \\
183 \pm 9.5 \\
56.0 \pm 1.6 \\
9.0 \pm 0.54\end{array}$ & $\begin{array}{c}41.5 \pm 1.2 \\
98 \pm 9 \\
216 \pm 25 \\
58.0 \pm 4 \\
10.2 \pm 1.4\end{array}$ & $\begin{array}{c}2.33 \pm 0.04 \\
8.1 \pm 2 \\
11.7 \pm 1.4 \\
3.80 \pm 0.11 \\
1.24 \pm 0.10\end{array}$ & $\begin{array}{r}2.29 \pm 0.17 \\
6.1 \pm 0.27 \\
11.89 \pm 0.78 \\
3.73 \pm 0.09 \\
1.29 \pm 0.11\end{array}$ \\
\hline 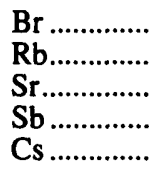 & $\begin{array}{c}6.5 \pm 0.32 \\
10 \pm 6.3 \\
1,340 \pm 67 \\
6.61 \pm 0.2 \\
7.76 \pm 0.23\end{array}$ & $\begin{array}{c}12 \pm 4 \\
125 \pm 10 \\
1,700 \pm 300 \\
6.9 \pm 0.6 \\
8.6 \pm 1.1\end{array}$ & $\begin{array}{c}21.3 \pm 1.1 \\
4.2 \pm 0.76 \\
97 \pm 5.8 \\
.259 \pm 0.01 \\
.414 \pm 0.012\end{array}$ & $\begin{array}{l}17 \\
5.05 \pm 0.11 \\
102 \\
.24 \\
.44\end{array}$ \\
\hline $\begin{array}{l}\mathrm{Ba} . . . \ldots \ldots \ldots . . . \\
\mathrm{La} \ldots \ldots \ldots \ldots . . . . \\
\mathrm{Ce} . . . . . . . . . . . \\
\text { Nd............. } \\
\text { Sm ............ }\end{array}$ & $\begin{array}{r}2,450 \pm 74 \\
80.4 \pm 1.6 \\
139 \pm 2.7 \\
55 \pm 7.2 \\
14.2 \pm 0.3\end{array}$ & $\begin{array}{c}2,700 \pm 200 \\
82 \pm 2 \\
146 \pm 15 \\
57.8 \pm 1.6 \\
12.4 \pm 0.9\end{array}$ & $\begin{array}{l}69 \pm 2.8 \\
4.80 \pm 0.01 \\
9.19 \pm 0.18 \\
<12 \\
.899 \pm 0.009\end{array}$ & $\begin{array}{c}67.5 \pm 2.1 \\
5.1 \\
9 \\
.87\end{array}$ \\
\hline $\begin{array}{l}\text { Eu............ } \\
\text { Tb............. } \\
\text { Yb............ } \\
\text { Lu............. } \\
\text { Hf .............. }\end{array}$ & $\begin{array}{l}2.68 \pm 0.08 \\
1.79 \pm 0.054 \\
5.99 \pm 0.18 \\
1.12 \pm 0.046 \\
7.12 \pm 0.21\end{array}$ & $\begin{array}{c}2.5 \pm 0.4 \\
1.9 \pm 0.3 \\
7 \pm 3 \\
1.0 \pm 0.1 \\
7.9 \pm 0.4\end{array}$ & $\begin{array}{l}.176 \pm 0.004 \\
.104 \pm 0.003 \\
.366 \pm 0.01 \\
.099 \pm 0.004 \\
.410 \pm 0.002\end{array}$ & .17 \\
\hline $\begin{array}{l}\text { Ta............. } \\
\text { W.............. } \\
\text { Th............. } \\
\text { U............... }\end{array}$ & $\begin{array}{l}2.03 \pm 0.06 \\
4.93 \pm 0.25 \\
23.1 \pm 0.46 \\
10.7 \pm 0.9\end{array}$ & $\begin{array}{r}1.8 \pm 0.3 \\
4.6 \pm 1.6 \\
24.8 \pm 2.2 \\
12.0 \pm 0.5\end{array}$ & $\begin{array}{c}.194 \pm 0.03 \\
.52 \pm 0.05 \\
1.321 \pm 0.026 \\
.42 \pm 0.05\end{array}$ & $\begin{array}{c}.48 \\
1.342 \pm 0.036 \\
.436 \pm 0.012\end{array}$ \\
\hline
\end{tabular}

\footnotetext{
'Values taken from Ondov and others (1975).

${ }^{2}$ Values taken from NIST (National Institute of Standards and Technology) 1632b Certificate (National Bureau of Standards, 1985). Values with no error listed are NIST information values; all others are NIST certified values.
}

and Eastman-Kodak TEG-50-B, and two control samples, NIST 1633 (fly ash; different from 1633a) and NIST 1632b (bituminous coal), were included with each irradiation. The element concentration values for the NIST standards used for analysis have been reported previously (Palmer and Baedecker, 1989) and are largely based on the results of Ondov and others (1975).

A comparison of the results of this study with literature values for the control samples is given in table 1 . The analytical errors reported for the control NIST $1632 \mathrm{~b}$ in this study are based on counting statistics at the one-sigma level. NIST certified and information values are shown for NIST $1632 \mathrm{~b}$. Our determinations of concentrations in control $1632 \mathrm{~b}$ agree with all certified values within the stated errors and generally agree, within 10 percent, with the NIST information values that have no reported errors.

\section{RESULTS AND DISCUSSION}

The concentrations and their associated errors based on counting statistics for 29 elements for each of the Premium Coal samples are shown in table 2. Iron is the only major element (concentrations $>1$ percent) determined, and sodium and potassium are the only minor elements (concentrations $<1$ percent, $>0.1$ percent) determined. All other elements determined are trace elements. For many elements, the concentration values ranged over a factor of 5 among the eight Argonne Premium Coal samples.

The errors reported in table 2 are based on counting statistics only. Generally, the precision of the data based on the replicate analyses is within the counting errors for elements where the reported error is greater than 5 percent. For some elements with small counting errors, the analytical 
INSTRUMENTAL NEUTRON ACTIVATION ANALYSIS

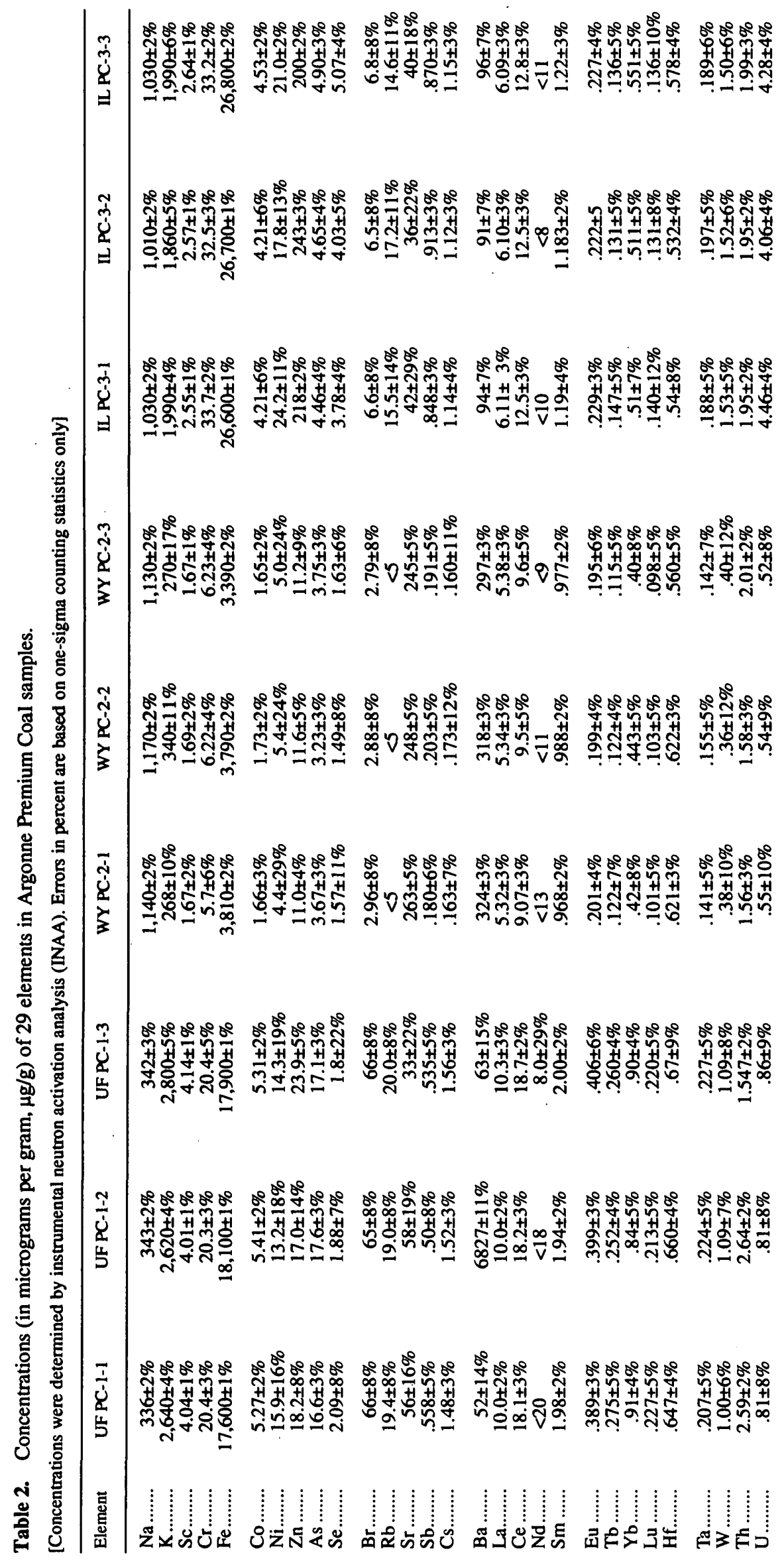




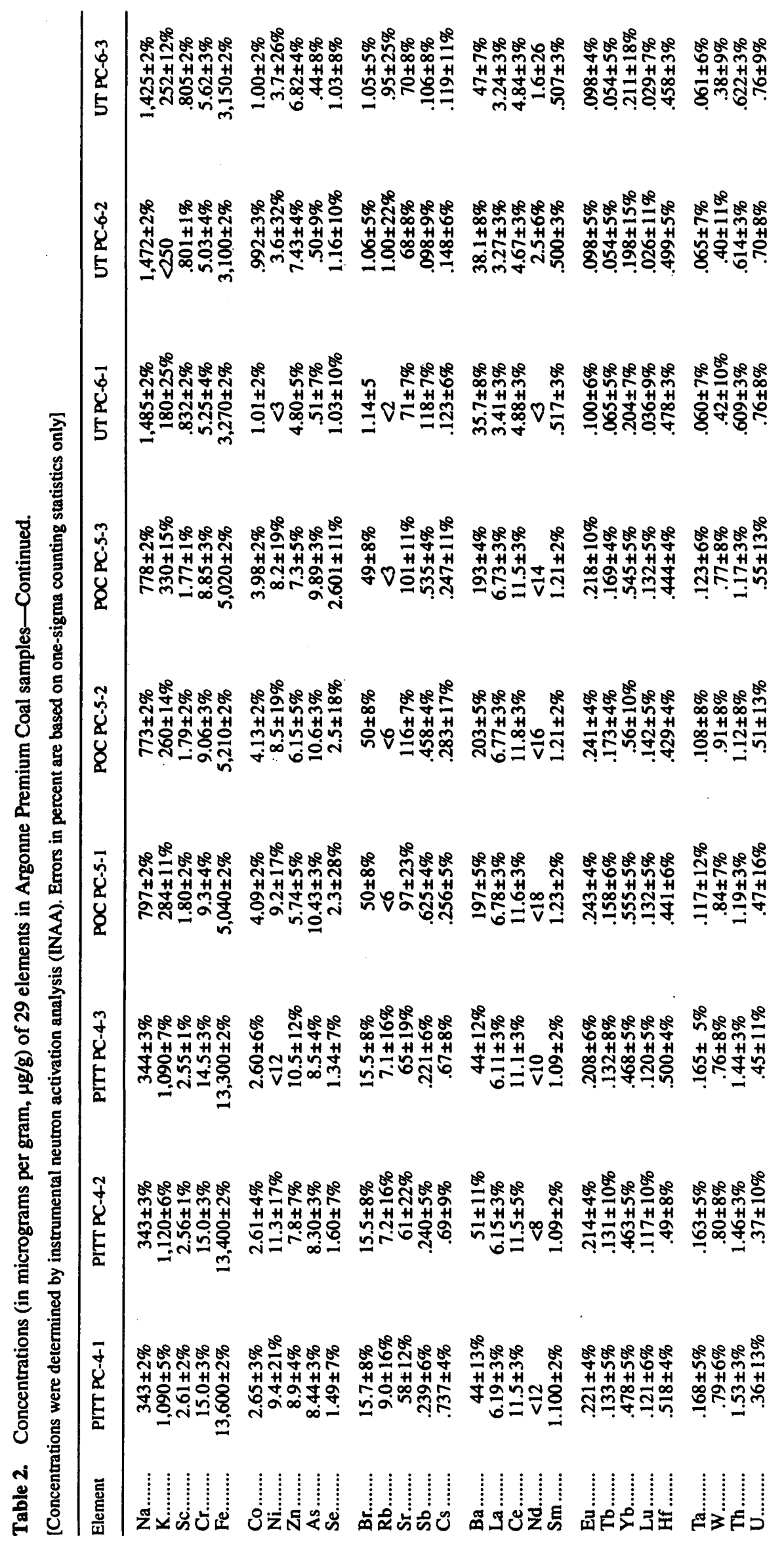




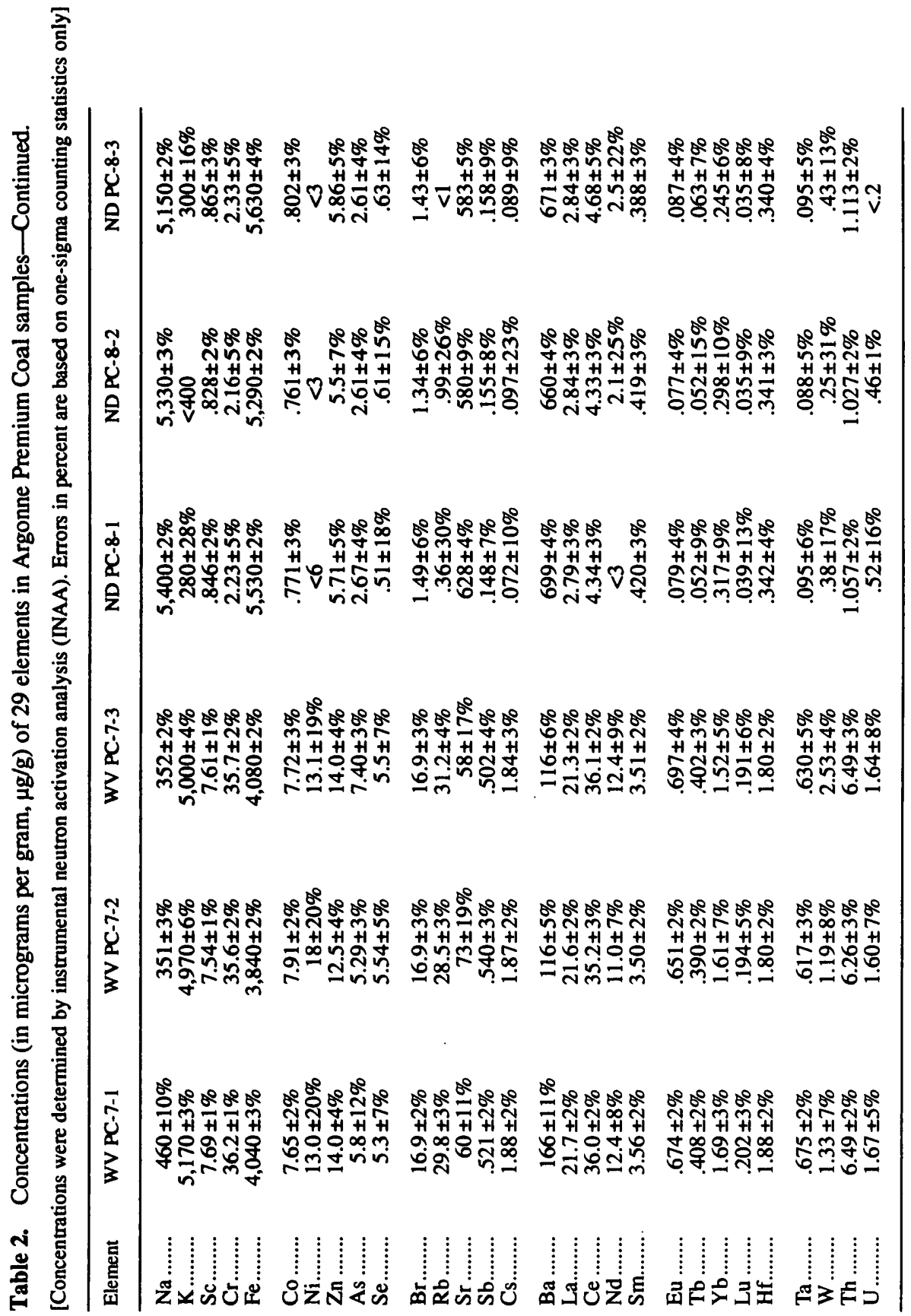


Table 3. Long-lived ( $>10$ hours) radionuclides.

[Table modified from Palmer and Baedecker (1989). d, day; $h$, hour, yr, year, $\mu \mathrm{g} / \mathrm{g}$, micrograms per gram]

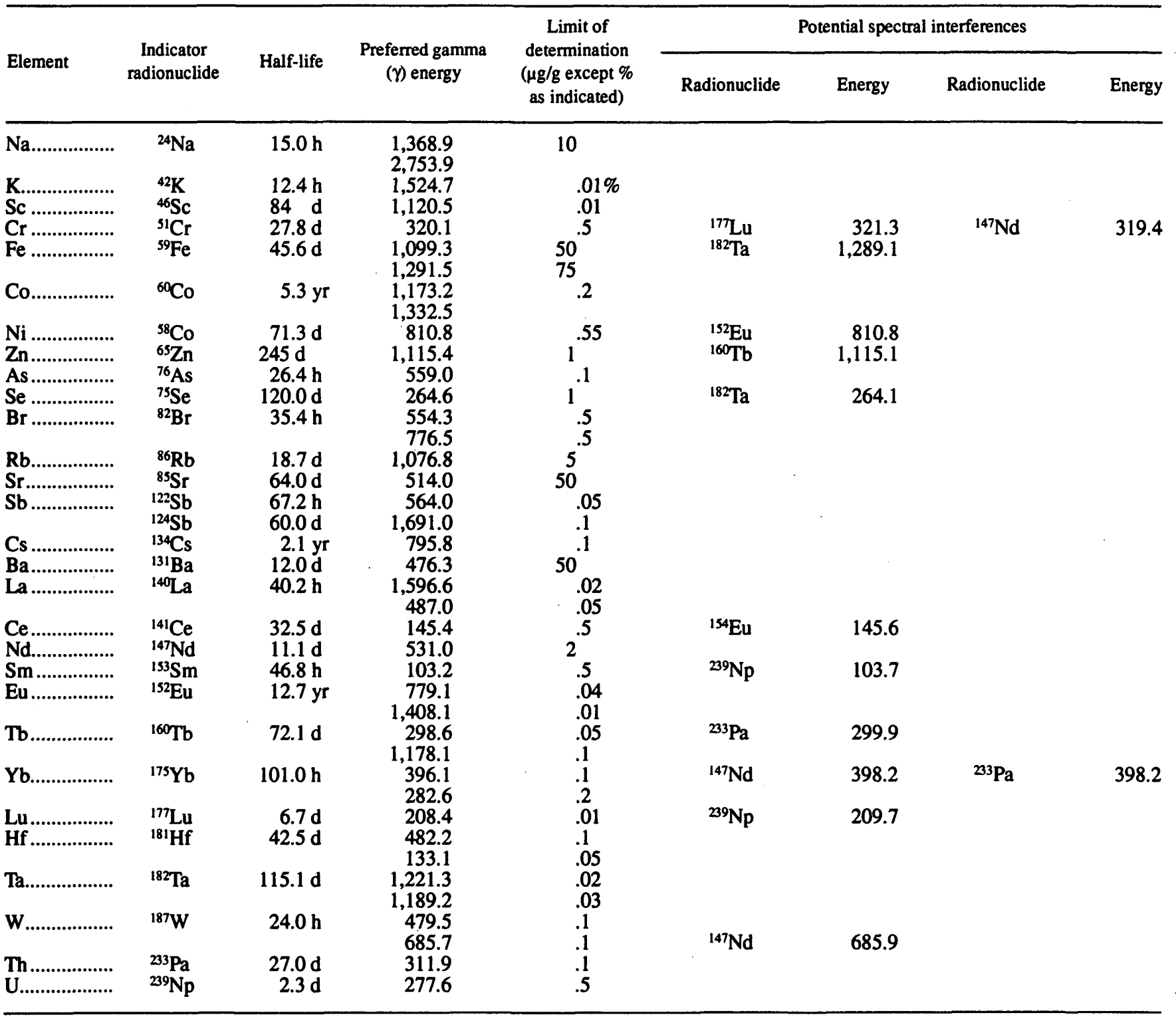

precision is poorer because of the other sources of error such as sample homogeneity or positioning during counting.

Errors reported in table 2 were generally less than 10 percent except for nickel, rubidium, and neodymium, in which the concentration was near or below the detection limit for all samples. Errors were also greater than 10 percent for barium in UF PC-1; uranium in PITT PC-4, POC PC-5, and ND PC-8; and ytterbium in UT PC-6 (table 2). Errors reported for potassium are variable even at the same concentration because it has the shortest half-life of the elements determined in this study, and the detection limit varies by nearly an order of magnitude during the 2-day counting cycle for the entire sample set.

In table 2, the concentrations reported for nickel in WY PC-2 and UT PC-6 and for rubidium in UT PC-6 and ND
PC- 8 are actually below the expected detection limits given in table 3 because the values in table 3 are determined for a "typical" coal matrix. The detection limits for individual coal samples may change because of variations in the concentrations of the most sensitive elements that dominate the gamma-ray spectrum and because of variations in the intensities of spectral interferences. The percent correction of each spectral interference for all premium coals is given in table 4. Generally, only a small correction is needed for most elements. Some elements, such as nickel, selenium, and samarium in some samples, require changes larger than 10 percent.

In addition to corrections made because of spectral interferences, barium and the light rare earth elements lanthanum, cerium, neodymium, and samarium were corrected 
Table 4. Average percent corrections made for spectral interferences on counts with the lowest errors during INAA (instrumental neutron activation analysis) of eight Argonne Premium Coal samples.

[ - indicates no correction was made; $<0.1$ indicates an extremely small correction was made. No corrections were required for spectral interference of the ${ }^{160} \mathrm{~Tb}$ line by the ${ }^{233} \mathrm{~Pa}$ line in any of these samples. Data for individual splits have been reported by Palmer (1991)]

\begin{tabular}{|c|c|c|c|c|c|c|c|c|c|c|}
\hline 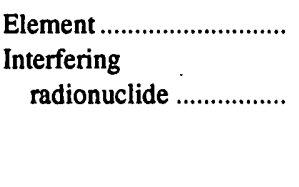 & $\begin{array}{c}\mathrm{Cr} \\
{ }^{177} \mathrm{Lu} \\
\text { and (or) } \\
{ }^{147} \mathrm{Nd}\end{array}$ & $\begin{array}{r}\mathrm{Fe} \\
{ }^{182} \mathrm{Ta}\end{array}$ & $\begin{array}{c}\mathrm{Ni} \\
{ }^{152} \mathrm{Eu}\end{array}$ & $\begin{array}{c}\mathrm{Zn} \\
{ }^{160} \mathrm{~Tb}\end{array}$ & $\begin{array}{c}\mathrm{Se} \\
{ }^{182} \mathrm{Ta}\end{array}$ & $\begin{array}{c}\mathrm{Ce} \\
{ }^{154} \mathrm{Eu}\end{array}$ & $\begin{array}{l}\mathrm{Sm} \\
{ }^{239} \mathrm{~Np}\end{array}$ & $\begin{array}{c}\mathrm{Yb} \\
{ }^{147} \mathrm{Nd} \\
\text { and (or) } \\
{ }^{233} \mathrm{~Pa}\end{array}$ & $\begin{array}{c}\mathrm{Lu} \\
{ }^{239} \mathrm{~Np}\end{array}$ & $\begin{array}{c}\mathrm{W} \\
{ }^{147} \mathrm{Nd}\end{array}$ \\
\hline $\begin{array}{l}\text { UF PC-1 } \\
\text { WY PC- } 2 \ldots \ldots \ldots \ldots \ldots \ldots \ldots \\
\text { IL PC-3 } \\
\text { PITT PC-4 }\end{array}$ & $\begin{array}{l}2.3 \\
4.8 \\
1.2 \\
1.7\end{array}$ & $\begin{array}{r}<0.1 \\
.2 \\
<.1 \\
<.1\end{array}$ & $\begin{array}{c}10.5 \\
142 \\
4.5 \\
7.8\end{array}$ & $\begin{array}{r}3.3 \\
2.7 \\
.2 \\
4.0\end{array}$ & $\begin{array}{r}14.5 \\
13.1 \\
7.5 \\
14.2\end{array}$ & $\begin{array}{r}0.2 \\
.5 \\
.4\end{array}$ & $\begin{array}{r}4.5 \\
5.4 \\
26.5 \\
3.9\end{array}$ & $\begin{array}{r}0.3 \\
.4 \\
1.5 \\
.4\end{array}$ & $\begin{array}{l}3.0 \\
5.3 \\
3.8\end{array}$ & $\begin{array}{l}0.4 \\
.6 \\
.4\end{array}$ \\
\hline 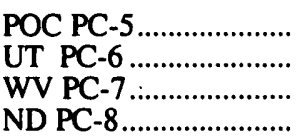 & $\begin{array}{l}2.5 \\
1.7 \\
1.5 \\
4.4\end{array}$ & $\begin{array}{r}<.1 \\
.1 \\
.5 \\
<.1\end{array}$ & $\begin{array}{r}10.0 \\
12.3 \\
14.8 \\
9.6\end{array}$ & $\begin{array}{l}6.2 \\
2.1 \\
6.3 \\
2.3\end{array}$ & $\begin{array}{r}7.8 \\
10.9 \\
13.5 \\
22.2\end{array}$ & $\frac{.3}{.3}$ & $\begin{array}{l}3.5 \\
9.7 \\
3.0 \\
8.9\end{array}$ & $\begin{array}{l}.6 \\
.4 \\
.6 \\
.5\end{array}$ & $\begin{array}{l}3.1 \\
1.3 \\
- \\
-\end{array}$ & $\begin{array}{r}-7 \\
1.7 \\
\end{array}$ \\
\hline
\end{tabular}

Table 5. Average percent correction made for fission product interferences during INAA (instrumental neutron activation analysis) of eight Argonne Premium Coal samples.

[Apparent concentration of each fission product is given in micrograms per gram $(\mu \mathrm{g} / \mathrm{g})$ per $\mu \mathrm{g} / \mathrm{g}$ of $\mathrm{U} .<0.1$ indicates a correction of less than 0.1 percent was made. Data for individual splits have been reported by Palmer (1991)]

\begin{tabular}{|c|c|c|c|c|c|}
\hline 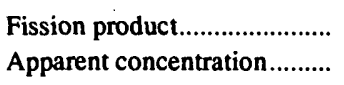 & $\begin{array}{c}{ }^{131} \mathbf{B a} \\
\left(^{1}\right)\end{array}$ & $\begin{array}{c}{ }^{140} \mathrm{La} \\
\text { (l) }^{1}\end{array}$ & $\begin{array}{l}{ }^{141} \mathrm{Ce} \\
0.27\end{array}$ & $\begin{array}{c}{ }^{147} \mathrm{Nd} \\
0.17\end{array}$ & $\begin{array}{c}{ }^{153} \mathrm{Sm} \\
0.00008\end{array}$ \\
\hline 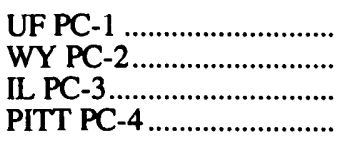 & $\begin{array}{r}4.9 \\
.6 \\
16.1 \\
3.4\end{array}$ & $\begin{array}{r}0.1 \\
.2 \\
1.0 \\
.1\end{array}$ & $\begin{array}{r}1.2 \\
1.5 \\
8.2 \\
.9\end{array}$ & $\begin{array}{r}20.6 \\
2.8 \\
26.8 \\
2.7\end{array}$ & $\begin{array}{l}<0.1 \\
<.1 \\
<.1 \\
<.1\end{array}$ \\
\hline 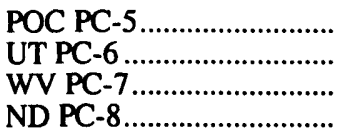 & $\begin{array}{r}.9 \\
7.1 \\
3.8 \\
.1\end{array}$ & $\begin{array}{l}.1 \\
.4 \\
.1 \\
.3\end{array}$ & $\begin{array}{l}1.2 \\
4.0 \\
1.3 \\
2.7\end{array}$ & $\begin{array}{r}2.5 \\
25.0 \\
2.2 \\
2.9\end{array}$ & $\begin{array}{l}<.1 \\
<.1 \\
<.1 \\
<.1\end{array}$ \\
\hline
\end{tabular}

${ }^{\mathrm{I}}$ Apparent concentration of element in $\mu \mathrm{g} / \mathrm{g}$ per $\mu \mathrm{g} / \mathrm{g}$ of $\mathrm{U}$ is time dependent.

${ }^{2}$ Correction made on upper limit value.

for interference because of neutron-induced fission of ${ }^{235} \mathrm{U}$; table 5 shows the percent correction for these elements. However, corrections for barium and lanthanum are time dependent and therefore vary during the counting of the samples. The concentration of barium, $\mathrm{Ba}_{\text {corr }}$ (corrected for the time-dependent fission correction factor), was calculated by using the formula:

$$
\mathrm{Ba}_{\text {cort }}=\mathrm{Ba}_{\text {meas }}-2.9 \mathrm{Ue}^{0.0402 t}
$$

and the concentration of lanthanum, $\mathrm{La}_{\text {corr }}$ (corrected for the time-dependent fission correction factor), was calculated by using:

$$
\mathrm{La}_{\text {cort }}=\mathrm{La}_{\text {mess }}-0.002723 \mathrm{Ue}^{0.3592}
$$

where $t=$ time after bombardment in days, $\mathrm{Ba}_{\text {meas }}$ and $\mathrm{La}_{\text {meas }}$ are the uncorrected barium and lanthanum concentrations, and $U$ is the concentration of uranium. The constant 0.002723 in the La equation is calculated by assuming a ${ }^{235} \mathrm{U}$ cross section of 580 barns, which agrees with the experimental data within \pm 1 percent. The half-lives for ${ }^{131} \mathrm{Ba}$ and ${ }^{239} \mathrm{~Np}(\mathrm{U})$ and ${ }^{140} \mathrm{La}$ were taken from table 3. The half-life of ${ }^{140} \mathrm{Ba}$, which decays to the measured ${ }^{140} \mathrm{La}$, was assumed to be 12.8 days. The fission correction factors are generally quite small except for barium and cerium in IL PC-3, which are about 16 and 8 percent, respectively, and for barium and 
neodymium in UT PC-6, which have correction factors as high as 7 and 5 percent, respectively.

\section{REFERENCES}

Baedecker, P.A., and Grossman, J.N., 1989, The computer analysis of high resolution gamma-ray spectra from instrumental neutron activation analysis experiments: U.S. Geological Survey Open-File Report 89-454, 98 p.

-1994, The SPECTRA program library; a PC based system for gamma-ray spectra analysis and INAA data reduction: U.S. Geological Survey Open-File Report 94-168, 52 p.

Block, C., and Dams, R., 1973, Determination of trace elements in coal by instrumental neutron activation analysis: Analytica Chimica Acta, v. 68, no. 1, p. 11-24.

Currens, J.C., Bragg, L.J., and Hower, J.C., 1986, Analysis of coal samples from the Princess district, Kentucky (Boyd, Carter, Greenup, and Lawrence Counties and part of Lewis County): Kentucky Geological Survey, series XI, Information Circular $18,128 \mathrm{p}$.

-1987, Analysis of coal samples from the Hazard District, Kentucky (Breathitt, Knott, Leslie, and Perry Counties and parts of Letcher and Harlan Counties): Kentucky Geological Survey, series XI, Information Circular 19, 301 p.

Gluskoter, H.J., Ruch, R.R., Miller, W.G., Cahill, R.A., Dreher, G.B., and Kuhn, J.K., 1977, Trace elements in coal: occurrence and distribution: Illinois State Geological Survey Circular No. 499, 154 p.

Massoni, C.J., Fones, R.V., and Simon, F.O., 1973, A pneumatic sample changer for gamma-ray spectroscopy: Review of Scientific Instruments, v. 44, no. 9, p. 1340-1352.

National Bureau of Standards, 1985, National Bureau of Standards certificate of analysis, standard reference material $1632 \mathrm{~b}$, trace elements in coal (bituminous): Gaithersburg, Md., National Bureau of Standards, 5 p.

Oman, C.L., Bragg, L.J., Nook, H.M., Schwarz, L.J., Harris, J.L., Jr., Rega, N.H., and Crowley, S.S., 1981, Chemical analysis of 45 Maryland coal samples: U.S. Geological Survey OpenFile Report 81-1099, 56 p.

Ondov, J.M., Zoller, W.H., Olmez, Ilham, Aras, N.K., Gordon, G.E., Rancitelli, L.A., Abel, K.H., Filby, R.H., Shah, K.R., and Ragaini, R.C., 1975, Elemental concentrations in the National Bureau of Standards' environmental coal and fly ash standard reference materials: Analytical Chemistry, v. 47, no. 7, p. 1102-1109.

Palmer, C.A., 1991, The determination of 29 elements in eight Argonne Premium Coal samples by instrumental neutron activation analysis, in Palmer, C.A., and Walthall, F.G., eds., The chemical analysis of Argonne Premium Coal samples: U.S. Geological Survey Open-File Report 91-638, chap. F, p. $50-63$.

Palmer, C.A., and Baedecker, P.A., 1989, The determination of 41 elements in whole coal by instrumental neutron activation analysis, in Golightly, D.W., and Simon, F.O., eds., Methods for sampling and inorganic analysis of coal: U.S. Geological Survey Bulletin 1823, p. 27-34.

Rowe, J.J., and Steinnes, E., 1977a, Determination of 30 elements in coal and fly ash by thermal and epithermal neutron activation analysis: Talanta, v. 24, p. 433-439.

$-1977 \mathrm{~b}$, Instrumental activation analysis of coal and fly ash with thermal and epithermal neutrons: Journal of Radioanalytical Chemistry, v. 37, no. 2, p. 849-856.

Swaine, D.J., 1985, Modem methods in bituminous coal analysis: trace elements CRC Critical Reviews in Analytical Chemistry, v. 15 , no. 4 , p. $315-346$.

Vorres, K.S., 1990, The Argonne Premium Coal Sample Program: Energy and Fuels, v. 4, no. 5, p. 420-426.

Zubovic, P., Oman, C.L., Bragg, L.J., Coleman, S.L., Rega, N.H., Lemaster, M.E., Golightly, D.W., and Puskas, J., 1980, Chemical analysis of 659 coal samples from the Eastern United States: U.S. Geological Survey Open-File Report 80-2003, $513 \mathrm{p}$.

Zubovic, P., Oman, C.L., Coleman, S.L., Bragg, L.J., Kerr, P.T., Kozey, K.M., Simon, F.O., Rowe, J.J., Medlin, J.H., and Walker, F.E., 1979, Chemical analysis of 617 coal samples from the Eastem United States: U.S. Geological Survey Open-File Report 79-665, 453 p. 


\title{
Determination of Selected Elements in Coal Ash from Eight Argonne Premium Coal Samples by Atomic Absorption Spectrometry and Atomic Emission Spectrometry
}

\author{
By Michael W. Doughten
}

\begin{abstract}
Methods for the determination of 22 elements in coal ash from Argonne Premium Coals by inductively coupled argon plasma-atomic emission spectrometry and flame and graphite furnace atomic absorption spectrometry are described. Coal ashes were analyzed in triplicate to determine the precision of the methods. Results of the analyses of National Institute of Standards and Technology (NIST) standard reference materials 1633 and $1633 \mathrm{a}$ are reported. Accuracy of the methods was determined by comparing element concentrations in standard reference materials determined in this study with their certified values and literature values.
\end{abstract}

\section{INTRODUCTION}

Procedures are described and results are presented for the determination of 22 elements in the coal ashes from 8 Argonne Premium Coal samples by inductively coupled argon plasma-atomic emission spectrometry (ICAP-AES) and atomic absorption spectrometry (AAS). Results of the ICAP-AES and AAS analyses of two standard reference materials from the National Institute of Standards and Technology (formerly the National Bureau of Standards, NBS), NIST 1633 and 1633a (coal fly ashes), are included and are compared with their certified values as well as with other values reported in the literature. Cadmium and lead were determined by graphite furnace atomic absorption spectrometry (GFAAS); cobalt and lithium were determined by flame atomic absorption spectrometry (FAAS). All other elements were determined by ICAP-AES. All the analyses described in this paper were performed in the U.S. Geological Survey laboratory in Reston, Va.

\section{SAMPLE PREPARATION}

Raw coal samples were ashed by weighing $70 \mathrm{~g}$ of coal into a previously weighed porcelain crucible. The cru- cible was placed in an electric furnace, which was slowly heated to $200^{\circ} \mathrm{C}$. After 1.5 hours at $200^{\circ} \mathrm{C}$, the temperature was increased to $350^{\circ} \mathrm{C}$ and was held at that temperature for 2 hours. The temperature was then increased to $525^{\circ} \mathrm{C}$ and maintained for about 36 hours. After the sample cooled for 1 to 2 hours, the weight of the ash was determined by subtracting the weight of the crucible from the weight of the crucible plus ash. Ash yield was reported as percent ash and was calculated by:

$$
\text { Percent ash }=\frac{(\text { weight ash })}{(\text { weight coal })} \times 100
$$

Percent ash data are listed in table 1.

Sample solutions for analysis by ICAP-AES and AAS were prepared by weighing $100 \mathrm{mg}$ of the coal ash and placing it in a 75-mL Teflon screwcap bomb, then adding $7 \mathrm{~mL}$ of concentrated nitric acid. The bomb was capped and heated on a hotplate overnight at $200^{\circ} \mathrm{C}$. After cooling, the bomb was uncapped, and $2 \mathrm{~mL}$ of concentrated nitric acid, 2 $\mathrm{mL}$ of concentrated perchloric acid, and $10 \mathrm{~mL}$ of hydrofluoric acid were added. All acids used were reagent grade. The bomb was then recapped and again heated on a hotplate at $200^{\circ} \mathrm{C}$ for 4 hours. The bomb was uncapped, and the solution evaporated to dryness. The sample was allowed to

Table 1. Coal ash yields for Argonne Premium Coal samples.

[Coal ash yields determined by Larry Winters, U.S. Geological Survey]

\begin{tabular}{|c|c|}
\hline Coal sample & Percent ash \\
\hline 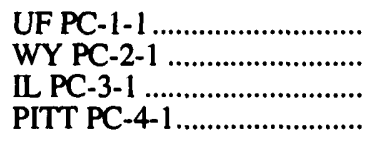 & $\begin{array}{r}13.5 \\
8.5 \\
16.2 \\
9.2\end{array}$ \\
\hline 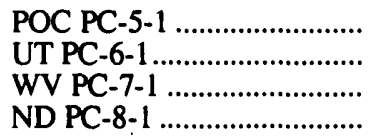 & $\begin{array}{r}5.3 \\
4.6 \\
19.4 \\
9.5\end{array}$ \\
\hline
\end{tabular}


cool, and $10 \mathrm{~mL}$ of $2 \mathrm{~N}$ hydrochloric acid was added. The bomb was recapped once again and gently heated until the solution was clear, indicating complete dissolution. The solution was then transferred to a $15-\mathrm{mL}$ polyethylene tube. This digestion procedure was used to determine that the concentration of the coal ash in solution was 1 percent.

\section{SAMPLE ANALYSIS}

The determinations of $\mathrm{Ba}, \mathrm{Be}, \mathrm{Cr}, \mathrm{Cu}, \mathrm{Mn}, \mathrm{Ni}, \mathrm{Sr}, \mathrm{V}, \mathrm{Y}$, $\mathrm{Zn}, \mathrm{K}, \mathrm{P}$, and $\mathrm{Ti}$ were made directly on this solution by ICAP-AES using a Jarrell-Ash model 1160 Atomcomp ICP system. Cobalt and lithium were determined on this solution by FAAS using a Perkin-Elmer model 5000 atomic absorption spectrometer. A deuterium arc lamp background corrector was used for Co. Lithium requires no background correction. Concentrations for $\mathrm{Co}$ and $\mathrm{Li}$ were calculated from a calibration curve established by analyzing a set of cobalt and lithium standard solutions.

The sample solution was diluted 1 to 10 with $2 N$ hydrochloric acid and analyzed for sodium and magnesium by ICAP-AES. Cadmium was determined on this solution by using a Perkin-Elmer atomic absorption spectrometer with a graphite furnace assembly (model HGA 500) and a Zeeman background correction system. Lead was determined on this solution by using a Perkin-Elmer model 603 atomic absorption spectrometer with a graphite furnace

Table 2. GFAAS (graphite furnace atomic absorption spectrometry) operating conditions.

\begin{tabular}{|c|c|c|}
\hline & Cd & $\mathrm{Pb}$ \\
\hline 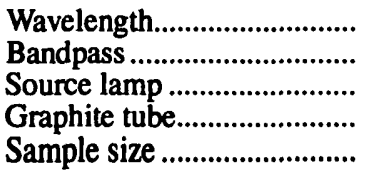 & $\begin{array}{l}228.8 \mathrm{~nm} \\
0.7 \mathrm{~nm} \\
\text { Hollow cathode } \\
\text { Uncoated } \\
20 \mu \mathrm{L}\end{array}$ & $\begin{array}{l}283.3 \mathrm{~nm} \\
0.7 \mathrm{~nm} \\
\text { Hollow cathode } \\
\text { Uncoated } \\
10 \mu \mathrm{L}\end{array}$ \\
\hline $\begin{array}{l}\text { Matrix modifier, } 2 \text { percent } \\
\text { solution of } \mathrm{NH}_{4} \mathrm{H}_{2} \mathrm{PO}_{4} \ldots . . \\
\text { Drying temperature .............. } \\
\text { Drying time: }\end{array}$ & $\begin{array}{l}10 \mu \mathrm{L} \\
110^{\circ} \mathrm{C}\end{array}$ & $\begin{array}{l}10 \mu \mathrm{L} \\
110^{\circ} \mathrm{C}\end{array}$ \\
\hline 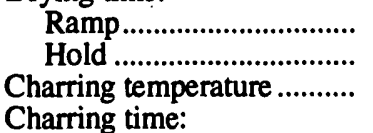 & $\begin{array}{l}10 \mathrm{sec} \\
30 \mathrm{sec} \\
250^{\circ} \mathrm{C}\end{array}$ & $\begin{array}{l}0 \mathrm{sec} \\
30 \mathrm{sec} \\
950^{\circ} \mathrm{C}\end{array}$ \\
\hline 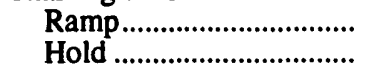 & $\begin{array}{r}5 \mathrm{sec} \\
25 \mathrm{sec}\end{array}$ & $\begin{array}{r}0 \mathrm{sec} \\
20 \mathrm{sec}\end{array}$ \\
\hline $\begin{array}{l}\text { Atomizing temperature ........ } \\
\text { Atomizing time: }\end{array}$ & $2,300^{\circ} \mathrm{C}$ & $2,700^{\circ} \mathrm{C}$ \\
\hline 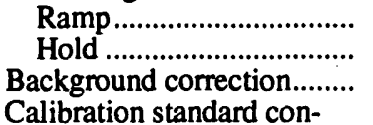 & $\begin{array}{l}0 \mathrm{sec} \\
5 \mathrm{sec} \\
\text { Zeeman }\end{array}$ & $\begin{array}{c}0 \mathrm{sec} \\
5 \mathrm{sec} \\
\text { Deuterium }\end{array}$ \\
\hline 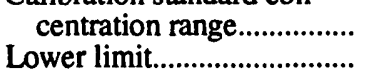 & $\begin{array}{l}0-4 \mathrm{ng} / \mathrm{mL} \\
0.2 \mathrm{ng} / \mathrm{mL}\end{array}$ & $\begin{array}{r}0-0.2 \mu \mathrm{g} / \mathrm{mL} \\
0.01 \mu \mathrm{g} / \mathrm{mL}\end{array}$ \\
\hline
\end{tabular}

Table 3. FAAS (flame atomic absorption spectrometry) operating conditions.

[Flame is fuel lean air-acetylene]

Co

Wavelength

Bandpass.

Background correction .....

Calibration standard con-

centration range

Lower limit.
Source lamp...

$240.7 \mathrm{~nm}$
$0.7 \mathrm{~nm}$
Hollow cathode
Deuterium

$0-5 \mu \mathrm{g} / \mathrm{mL}$
$0.1 \mu \mathrm{g} / \mathrm{mL}$

$240.7 \mathrm{~nm}$

$0.1 \mu \mathrm{g} / \mathrm{mL}$
$\mathrm{Li}$

$670.8 \mathrm{~nm}$
$0.4 \mathrm{~nm}$
Hollow cathode
None
$0-2 \mu \mathrm{g} / \mathrm{mL}$
$0.1 \mu \mathrm{g} / \mathrm{mL}$

Table 4. ICAP-AES (inductively coupled argon plasma-atomic emission spectrometry) wavelengths, calibration ranges, and detection limits.

\begin{tabular}{|c|c|c|c|}
\hline Element & $\begin{array}{l}\text { Wavelength } \\
(\mathrm{nm})\end{array}$ & $\begin{array}{c}\text { Calibration } \\
\text { range }^{1} \\
(\mu \mathrm{g} / \mathrm{mL})\end{array}$ & $\begin{array}{c}\text { Limit of } \\
\text { detection } \\
\text { (in solution } \\
(\mu \mathrm{g} / \mathrm{mL})\end{array}$ \\
\hline $\begin{array}{l}\mathrm{Al} \\
\mathrm{Ba} \\
\mathrm{Be} \\
\mathrm{Ca} \\
\mathrm{Fe}\end{array}$ & $\begin{array}{l}308.2 \\
455.4 \\
313.0 \\
317.9 \\
259.9\end{array}$ & $\begin{array}{l}0-2 \\
0-20 \\
0-1 \\
0-1 \\
0-20\end{array}$ & $\begin{array}{r}0.5 \\
.5 \\
.1 \\
.5 \\
.5\end{array}$ \\
\hline $\begin{array}{l}\mathrm{K} \\
\mathrm{Mg} \\
\mathrm{Mn} \\
\mathrm{Na} \\
\mathrm{Ni}\end{array}$ & $\begin{array}{l}766.5 \\
280.2 \\
257.6 \\
589.0 \\
231.6\end{array}$ & $\begin{array}{l}10-200 \\
0-10 \\
0-10 \\
0-10 \\
0-1\end{array}$ & $\begin{array}{r}10 \\
.5 \\
.5 \\
.5 \\
.1\end{array}$ \\
\hline 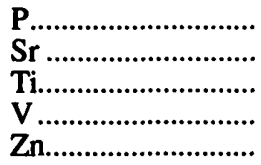 & $\begin{array}{l}214.9 \\
407.7 \\
334.9 \\
292.4 \\
213.8\end{array}$ & $\begin{array}{l}0-50 \\
0-5 \\
0-100 \\
0-1 \\
0-1\end{array}$ & $\begin{array}{l}1 \\
1.1 \\
.1 \\
.1\end{array}$ \\
\hline
\end{tabular}

'Calibration standard concentration range.

assembly (model HGA 2100) and a deuterium arc lamp background correction system. A 2 percent solution of ammonium phosphate $\left(\mathrm{NH}_{4} \mathrm{H}_{2} \mathrm{PO}_{4}\right)$ (see table 2 ) was used as a matrix modifier for both $\mathrm{Cd}$ and $\mathrm{Pb}$. Concentrations for $\mathrm{Cd}$ and $\mathrm{Pb}$ were calculated from a calibration curve (absorbance versus concentration $(\mu \mathrm{g} / \mathrm{g})$ ) established from analyzing a set of $\mathrm{Cd}$ and $\mathrm{Pb}$ standard solutions. This diluted solution was further diluted to 1 to 100 with $2 N$ hydrochloric acid and analyzed for aluminum, calcium, and iron by ICAPAES.

All calibration solutions for AAS and AES were prepared in $2 N$ hydrochloric acid. Instrumental operating parameters for GFAAS and FAAS are listed in tables 2 and 3. ICAP-AES wavelengths and concentration ranges are listed in table 4. Trace- and major-element concentrations are listed in tables 5 and 6. 
Table 5. Trace-element concentrations (in micrograms per gram, ug/g) in coal ash from eight Argonne Premium Coal samples.

[ $\mathrm{Cd}$ and $\mathrm{Pb}$ were determined by graphite furnace atomic absorption spectrometry, $\mathrm{Co}$ and $\mathrm{Li}$ were determined by flame atomic absorption spectrometry, and all other element concentrations were determined by inductively coupled argon plasma-atomic emission spectrometry. —, no data]

\begin{tabular}{|c|c|c|c|c|c|c|c|c|c|c|c|c|c|c|}
\hline Coal ash & $\mathrm{Ba}$ & $\mathrm{Be}$ & $\mathrm{Cd}$ & Co & $\mathrm{Cr}$ & $\mathrm{Cu}$ & $\mathrm{Li}$ & $\mathrm{Mn}$ & $\mathbf{N i}$ & $\mathrm{Pb}$ & $\mathrm{Sr}$ & V & $\mathbf{Y}$ & $\mathrm{Zn}$ \\
\hline 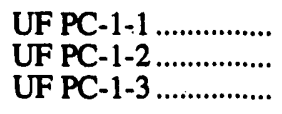 & $\begin{array}{l}400 \\
410 \\
420\end{array}$ & $\begin{array}{l}11 \\
11 \\
11\end{array}$ & $\begin{array}{r}0.53 \\
.51 \\
.54\end{array}$ & $\begin{array}{l}38 \\
38 \\
35\end{array}$ & $\begin{array}{l}150 \\
140 \\
150\end{array}$ & $\begin{array}{l}140 \\
140 \\
140\end{array}$ & $\begin{array}{l}110 \\
110 \\
110\end{array}$ & $\begin{array}{l}300 \\
310 \\
300\end{array}$ & $\begin{array}{l}110 \\
100 \\
110\end{array}$ & $\begin{array}{l}58 \\
55 \\
51\end{array}$ & $\begin{array}{l}440 \\
450 \\
430\end{array}$ & $\begin{array}{l}190 \\
190 \\
190\end{array}$ & $\begin{array}{l}69 \\
69 \\
68\end{array}$ & $\begin{array}{l}140 \\
140 \\
150\end{array}$ \\
\hline $\begin{array}{l}\text { WY PC-2-1............ } \\
\text { WY PC-2-2............ } \\
\text { WY PC-2-3............ }\end{array}$ & $\begin{array}{l}180 \\
180 \\
170\end{array}$ & $\begin{array}{l}3.1 \\
2.8 \\
2.9\end{array}$ & $\begin{array}{l}1.1 \\
1.1 \\
1.1\end{array}$ & $\begin{array}{l}19 \\
19 \\
19\end{array}$ & $\begin{array}{l}73 \\
75 \\
71\end{array}$ & $\begin{array}{l}140 \\
140 \\
150\end{array}$ & $\begin{array}{l}48 \\
49 \\
48\end{array}$ & $\begin{array}{l}240 \\
250 \\
220\end{array}$ & $\begin{array}{l}58 \\
55 \\
61\end{array}$ & $\begin{array}{l}37 \\
35 \\
32\end{array}$ & $\begin{array}{l}1,800 \\
1,700 \\
1,800\end{array}$ & $\begin{array}{l}160 \\
160 \\
160\end{array}$ & $\begin{array}{l}46 \\
44 \\
44\end{array}$ & $\begin{array}{l}120 \\
120 \\
120\end{array}$ \\
\hline 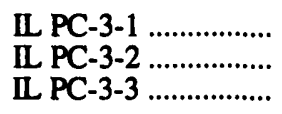 & $\begin{array}{l}420 \\
540 \\
540\end{array}$ & $\begin{array}{l}4.8 \\
4.6 \\
4.6\end{array}$ & $\begin{array}{l}3.7 \\
4.0 \\
3.5\end{array}$ & $\begin{array}{l}26 \\
28 \\
26\end{array}$ & $\begin{array}{l}190 \\
200 \\
190\end{array}$ & $\begin{array}{l}65 \\
64 \\
64\end{array}$ & $\begin{array}{l}48 \\
49 \\
48\end{array}$ & $\begin{array}{l}470 \\
480 \\
470\end{array}$ & $\begin{array}{l}110 \\
120 \\
110\end{array}$ & $\begin{array}{l}42 \\
39 \\
39\end{array}$ & $\begin{array}{l}180 \\
180 \\
180\end{array}$ & $\begin{array}{l}200 \\
200 \\
190\end{array}$ & $\begin{array}{l}26 \\
26 \\
26\end{array}$ & $\begin{array}{l}1,000 \\
1,100 \\
1,200\end{array}$ \\
\hline $\begin{array}{l}\text { PITT PC-4-1 ............ } \\
\text { PITT PC-4-2........... } \\
\text { PITT PC-4-3 ........... }\end{array}$ & $\begin{array}{l}460 \\
450 \\
430\end{array}$ & $\begin{array}{l}8.3 \\
8.3 \\
8.5\end{array}$ & $\begin{array}{l}.64 \\
.63 \\
.68\end{array}$ & $\begin{array}{l}26 \\
28 \\
26\end{array}$ & $\begin{array}{l}160 \\
150 \\
140\end{array}$ & $\begin{array}{l}60 \\
58 \\
60\end{array}$ & $\begin{array}{l}95 \\
93 \\
94\end{array}$ & $\begin{array}{l}200 \\
190 \\
190\end{array}$ & $\begin{array}{l}99 \\
90 \\
88\end{array}$ & $\begin{array}{l}32 \\
32 \\
32\end{array}$ & $\begin{array}{l}700 \\
700 \\
680\end{array}$ & $\begin{array}{l}160 \\
160 \\
160\end{array}$ & $\begin{array}{l}47 \\
46 \\
46\end{array}$ & $\begin{array}{l}89 \\
81 \\
84\end{array}$ \\
\hline 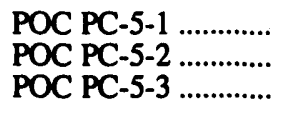 & $\begin{array}{l}310 \\
310 \\
310\end{array}$ & $\begin{array}{l}15 \\
15 \\
15\end{array}$ & $\begin{array}{l}1.6 \\
1.4 \\
1.4\end{array}$ & $\begin{array}{l}71 \\
71 \\
71\end{array}$ & $\begin{array}{l}180 \\
160 \\
180\end{array}$ & $\begin{array}{l}220 \\
220 \\
220\end{array}$ & $\begin{array}{l}110 \\
110 \\
110\end{array}$ & $\begin{array}{l}300 \\
300 \\
300\end{array}$ & $\begin{array}{l}130 \\
120 \\
130\end{array}$ & $\begin{array}{l}48 \\
45 \\
45\end{array}$ & $\begin{array}{l}1,600 \\
1,600 \\
1,600\end{array}$ & $\begin{array}{l}200 \\
200 \\
200\end{array}$ & $\begin{array}{l}120 \\
130 \\
110\end{array}$ & $\begin{array}{l}73 \\
77 \\
74\end{array}$ \\
\hline $\begin{array}{l}\text { UT PC-6-1 } \\
\text { UT PC-6-2 }\end{array}$ & $\begin{array}{l}690 \\
660\end{array}$ & $\begin{array}{l}2.8 \\
2.7\end{array}$ & $\begin{array}{l}1.3 \\
1.3\end{array}$ & $\begin{array}{l}18 \\
18\end{array}$ & $\begin{array}{r}110 \\
99\end{array}$ & $\begin{array}{l}84 \\
82\end{array}$ & $\begin{array}{l}110 \\
110\end{array}$ & $\begin{array}{l}88 \\
88\end{array}$ & $\begin{array}{l}73 \\
71\end{array}$ & $\begin{array}{l}34 \\
34\end{array}$ & $\begin{array}{l}1,300 \\
1,300\end{array}$ & $\begin{array}{l}86 \\
87\end{array}$ & $\begin{array}{l}45 \\
46\end{array}$ & $\begin{array}{l}140 \\
130\end{array}$ \\
\hline 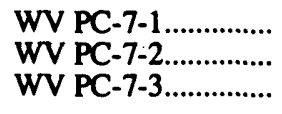 & $\begin{array}{l}610 \\
630 \\
680\end{array}$ & $\begin{array}{l}9.7 \\
9.8 \\
10 .\end{array}$ & $\begin{array}{l}.40 \\
.37 \\
.44\end{array}$ & $\begin{array}{l}40 \\
43 \\
42\end{array}$ & $\begin{array}{l}210 \\
210 \\
200\end{array}$ & $\begin{array}{l}100 \\
100 \\
100\end{array}$ & $\begin{array}{l}150 \\
150 \\
150\end{array}$ & $\begin{array}{l}80 \\
78 \\
77\end{array}$ & $\begin{array}{l}81 \\
82 \\
82\end{array}$ & $\begin{array}{l}63 \\
61 \\
63\end{array}$ & $\begin{array}{l}250 \\
240 \\
260\end{array}$ & $\begin{array}{l}220 \\
230 \\
220\end{array}$ & $\begin{array}{l}55 \\
54 \\
57\end{array}$ & $\begin{array}{l}65 \\
66 \\
63\end{array}$ \\
\hline $\begin{array}{l}\text { ND PC-8-1 } \ldots \ldots \ldots \ldots . . \\
\text { ND PC-8 } 2 \ldots \ldots \ldots \ldots \ldots \\
\text { ND PC-8 } 3 \ldots \ldots \ldots \ldots \ldots\end{array}$ & $\begin{array}{l}4,500 \\
4,100 \\
4,700\end{array}$ & $\begin{array}{l}1.9 \\
1.8 \\
-\end{array}$ & $\begin{array}{l}.50 \\
.46 \\
.48\end{array}$ & $\begin{array}{l}<10 \\
<10 \\
<10\end{array}$ & $\begin{array}{l}27 \\
26 \\
24\end{array}$ & $\begin{array}{l}59 \\
37 \\
52\end{array}$ & $\begin{array}{l}28 \\
28 \\
30\end{array}$ & $\begin{array}{l}840 \\
830 \\
850\end{array}$ & $\begin{array}{l}15 \\
15 \\
12\end{array}$ & $\begin{array}{l}16 \\
16 \\
16\end{array}$ & $\begin{array}{l}5,400 \\
5,300 \\
5,300\end{array}$ & $\begin{array}{l}37 \\
36 \\
38\end{array}$ & $\begin{array}{l}20 \\
19 \\
-\end{array}$ & $\begin{array}{l}54 \\
49 \\
47\end{array}$ \\
\hline
\end{tabular}

Table 6. Major-element concentrations (in weight percent) in coal ash from eight Argonne Premium Coal samples

[Element concentrations were determined by inductively coupled argon plasma-atomic emission spectrometry]

\begin{tabular}{|c|c|c|c|c|c|c|c|c|}
\hline Coal ash & Al & $\mathrm{Ca}$ & $\mathrm{Fe}$ & $\mathbf{K}$ & $\mathbf{M g}$ & $\mathrm{Na}$ & $\mathbf{P}$ & $\mathbf{T i}$ \\
\hline $\begin{array}{l}\text { UF PC-1-1 .............. } \\
\text { UF PC-1-2 .............. } \\
\text { UF PC-1-3 ............. }\end{array}$ & $\begin{array}{l}11.9 \\
11.9 \\
11.8\end{array}$ & $\begin{array}{l}3.31 \\
3.30 \\
3.28\end{array}$ & $\begin{array}{l}13.8 \\
14.0 \\
13.6\end{array}$ & $\begin{array}{l}2.10 \\
2.10 \\
2.10\end{array}$ & $\begin{array}{r}0.61 \\
.61 \\
.61\end{array}$ & $\begin{array}{r}0.24 \\
.24 \\
.24\end{array}$ & $\begin{array}{r}0.056 \\
.059 \\
.061\end{array}$ & $\begin{array}{r}0.58 \\
.59 \\
.58\end{array}$ \\
\hline $\begin{array}{l}\text { WY PC-2-1 ............. } \\
\text { WY PC-2-2............ } \\
\text { WY PC- } 2-3 \ldots \ldots \ldots \ldots \ldots .\end{array}$ & $\begin{array}{l}8.18 \\
8.21 \\
8.26\end{array}$ & $\begin{array}{l}14.2 \\
13.6 \\
14.3\end{array}$ & $\begin{array}{l}4.21 \\
4.46 \\
4.28\end{array}$ & $\begin{array}{l}.33 \\
.33 \\
.31\end{array}$ & $\begin{array}{l}2.83 \\
2.78 \\
2.81\end{array}$ & $\begin{array}{l}1.40 \\
1.37 \\
1.40\end{array}$ & $\begin{array}{l}.31 \\
.29 \\
.30\end{array}$ & $\begin{array}{l}.66 \\
.66 \\
.65\end{array}$ \\
\hline 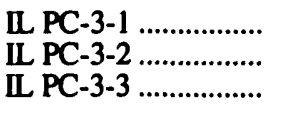 & $\begin{array}{l}7.75 \\
7.70 \\
7.72\end{array}$ & $\begin{array}{l}5.82 \\
5.96 \\
6.00\end{array}$ & $\begin{array}{l}16.8 \\
16.4 \\
17.2\end{array}$ & $\begin{array}{l}1.20 \\
1.20 \\
1.20\end{array}$ & $\begin{array}{l}.47 \\
.48 \\
.47\end{array}$ & $\begin{array}{l}.60 \\
.61 \\
.58\end{array}$ & $\begin{array}{l}.036 \\
.037 \\
.037\end{array}$ & $\begin{array}{l}.43 \\
.43 \\
.42\end{array}$ \\
\hline $\begin{array}{l}\text { PITT PC-4-1 ............ } \\
\text { PITT PC-4-2 ........... } \\
\text { PITT PC-4-3........... }\end{array}$ & $\begin{array}{l}10.8 \\
10.9 \\
10.8\end{array}$ & $\begin{array}{l}2.29 \\
2.23 \\
2.21\end{array}$ & $\begin{array}{l}14.6 \\
14.3 \\
14.2\end{array}$ & $\begin{array}{l}1.20 \\
1.20 \\
1.20\end{array}$ & $\begin{array}{l}.41 \\
.41 \\
.40\end{array}$ & $\begin{array}{l}.35 \\
.35 \\
.34\end{array}$ & $\begin{array}{l}.12 \\
.12 \\
.12\end{array}$ & $\begin{array}{l}.62 \\
.61 \\
.60\end{array}$ \\
\hline 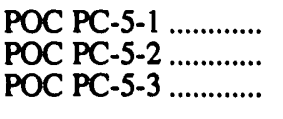 & $\begin{array}{l}10.4 \\
10.4 \\
10.3\end{array}$ & $\begin{array}{l}8.75 \\
8.53 \\
8.53\end{array}$ & $\begin{array}{l}9.67 \\
9.52 \\
9.50\end{array}$ & $\begin{array}{l}.51 \\
.53 \\
.53\end{array}$ & $\begin{array}{l}1.06 \\
1.04 \\
1.04\end{array}$ & $\begin{array}{l}1.57 \\
1.57 \\
1.54\end{array}$ & $\begin{array}{l}.042 \\
.041 \\
.040\end{array}$ & $\begin{array}{l}.72 \\
.72 \\
.72\end{array}$ \\
\hline 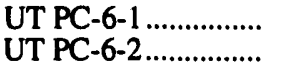 & $\begin{array}{l}7.56 \\
7.50\end{array}$ & $\begin{array}{l}9.07 \\
8.70\end{array}$ & $\begin{array}{l}6.16 \\
6.09\end{array}$ & $\begin{array}{l}.30 \\
.30\end{array}$ & $\begin{array}{l}.64 \\
.65\end{array}$ & $\begin{array}{l}2.75 \\
2.70\end{array}$ & $\begin{array}{l}.020 \\
.021\end{array}$ & $\begin{array}{l}.50 \\
.49\end{array}$ \\
\hline $\begin{array}{l}\text { WV PC-7-1........... } \\
\text { WV PC-7-2........... } \\
\text { WV PC-7-3............. }\end{array}$ & $\begin{array}{l}16.1 \\
16.4 \\
16.3\end{array}$ & $\begin{array}{l}.29 \\
.30 \\
.30\end{array}$ & $\begin{array}{l}2.04 \\
1.96 \\
1.95\end{array}$ & $\begin{array}{l}2.52 \\
2.58 \\
2.55\end{array}$ & $\begin{array}{l}.48 \\
.49 \\
.49\end{array}$ & $\begin{array}{l}.17 \\
.18 \\
.18\end{array}$ & $\begin{array}{l}.046 \\
.045 \\
.038\end{array}$ & $\begin{array}{l}1.34 \\
1.34 \\
1.34\end{array}$ \\
\hline $\begin{array}{l}\text { ND PC-8-1 } \\
\text { ND PC-8 } 2 \ldots \ldots \ldots \ldots \ldots \ldots \\
\text { ND PC-8-3 } \ldots \ldots \ldots \ldots \ldots \ldots . . .\end{array}$ & $\begin{array}{l}4.17 \\
4.22 \\
4.25\end{array}$ & $\begin{array}{l}16.0 \\
16.1 \\
16.5\end{array}$ & $\begin{array}{l}4.91 \\
4.95 \\
5.05\end{array}$ & $\begin{array}{l}.13 \\
.16 \\
.15\end{array}$ & $\begin{array}{l}4.16 \\
4.16 \\
4.26\end{array}$ & $\begin{array}{l}4.84 \\
4.89 \\
5.00\end{array}$ & $\begin{array}{l}.13 \\
.13 \\
.13\end{array}$ & $\begin{array}{l}.21 \\
.20 \\
.21\end{array}$ \\
\hline
\end{tabular}


Table 7. Comparison of element concentrations in NIST standard reference material 1633 determined in this study with certified values and with concentrations determined in other studies.

[Concentrations for the first 14 elements are in micrograms per gram $(\mu \mathrm{g} / \mathrm{g})$; others are in weight percent. Methods used in this study: ICAP-AES, inductively coupled argon plasma-atomic emission spectrometry; GFAAS, graphite furnace atomic absorption spectrometry; FAAS, flame atomic absorption spectrometry. NIST, National Institute of Standards and Technology, formerly the National Bureau of Standards (NBS). Certified and information values for NIST 1633 are from NBS (1975). —, no data]

\begin{tabular}{|c|c|c|c|c|c|c|c|}
\hline \multirow{2}{*}{ Element } & \multicolumn{2}{|c|}{ This study } & \multirow{2}{*}{$\begin{array}{l}\text { NBS } \\
(1975)^{1}\end{array}$} & \multirow{2}{*}{$\begin{array}{l}\text { Gladney and others } \\
\text { (1987) }\end{array}$} & \multirow{2}{*}{$\begin{array}{l}\text { Kane } \\
(1989)\end{array}$} & \multirow{2}{*}{$\begin{array}{l}\text { Ondov and others } \\
\text { (1975) }\end{array}$} & \multirow{2}{*}{$\begin{array}{l}\text { Rowe and Steinnes } \\
\text { (1977) }\end{array}$} \\
\hline & Method & Conc. & & & & & \\
\hline $\begin{array}{l}\mathrm{Ba}(\mu \mathrm{g} / \mathrm{g}) . . \\
\mathrm{Be} \ldots \ldots \ldots \ldots \ldots . . . \\
\mathrm{Cd} \ldots \ldots \ldots \ldots \ldots . . . \\
\mathrm{Co} \ldots \ldots \ldots \ldots . . . \\
\mathrm{Cr} \ldots \ldots \ldots \ldots \ldots . . . . .\end{array}$ & $\begin{array}{l}\text { ICAP-AES } \\
\text { ICAP-AES } \\
\text { GFAAS } \\
\text { FAAS } \\
\text { ICAP-AES }\end{array}$ & $\begin{array}{c}2,700 \\
11 \\
1.5 \\
41 \\
130\end{array}$ & $\begin{array}{c}- \\
1.45 \pm 0.06 \\
38 \\
131 \pm 2\end{array}$ & $\begin{aligned} 2,665 & \pm 160 \\
12.1 & \pm 1.0 \\
1.47 & \pm 0.15 \\
40 & \pm 3 \\
127 & \pm 10\end{aligned}$ & $\begin{array}{c}\overline{-} \\
1.56 \pm 0.26 \\
- \\
-\end{array}$ & 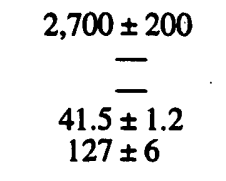 & $\begin{array}{c}2,540 \\
- \\
- \\
40.3 \pm 0.4 \\
129.2 \pm 2.7\end{array}$ \\
\hline 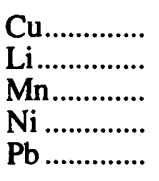 & $\begin{array}{l}\text { ICAP-AES } \\
\text { FAAS } \\
\text { ICAP-AES } \\
\text { ICAP-AES } \\
\text { GFAAS }\end{array}$ & $\begin{array}{r}130 \\
160 \\
510 \\
94 \\
70\end{array}$ & $\begin{array}{r}128 \pm 5 \\
- \\
493 \pm 7 \\
98 \pm 7 \\
70 \pm 4\end{array}$ & $\begin{array}{c}129 \pm 7 \\
170 \pm 80 \\
494 \pm 20 \\
98 \pm 6 \\
72 \pm 6\end{array}$ & $\begin{array}{c}130 \pm 6 \\
170 \pm 13 \\
496 \pm 34 \\
- \\
67 \pm 4\end{array}$ & $\begin{array}{c}- \\
- \\
496 \pm 19 \\
98 \pm 9 \\
75 \pm 5\end{array}$ & $\begin{array}{c}115 \pm 8 \\
- \\
488 \pm 14 \\
69 \pm 7 \\
-\end{array}$ \\
\hline $\begin{array}{l}\text { Sr............. } \\
\text { V................ } \\
\text { Y.............. } \\
\mathrm{Zn} . . . \ldots \ldots \ldots . . .\end{array}$ & $\begin{array}{l}\text { ICAP-AES } \\
\text { ICAP-AES } \\
\text { ICAP-AES } \\
\text { ICAP-AES }\end{array}$ & $\begin{array}{r}1,400 \\
220 \\
66 \\
210\end{array}$ & $\begin{array}{c}1,430 \pm 60 \\
214 \pm 8 \\
- \\
210 \pm 20\end{array}$ & $\begin{array}{c}1,380 \pm 100 \\
224 \pm 24 \\
64 \pm 4 \\
211 \pm 11\end{array}$ & $\frac{\bar{Z}}{210 \pm 10}$ & $\begin{array}{c}1,700 \pm 300 \\
235 \pm 13 \\
62 \pm 10 \\
216 \pm 25\end{array}$ & $\begin{array}{c}1,430 \pm 60 \\
237 \pm 20 \\
- \\
201 \pm 6\end{array}$ \\
\hline 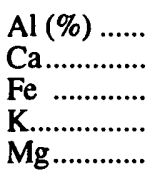 & $\begin{array}{l}\text { ICAP-AES } \\
\text { ICAP-AES } \\
\text { ICAP-AES } \\
\text { ICAP-AES } \\
\text { ICAP-AES }\end{array}$ & $\begin{array}{l}11.9 \\
4.58 \\
6.05 \\
1.80 \\
1.33\end{array}$ & $\begin{array}{l}- \\
\overline{-} \\
1.72 \\
1.98\end{array}$ & $\begin{array}{c}12.6 \pm 0.6 \\
4.65 \pm 0.34 \\
6.16 \pm 0.27 \\
1.69 \pm 0.09 \\
1.5 \pm 0.3\end{array}$ & $\frac{\bar{Z}}{\bar{Z}}$ & $\begin{array}{c}12.7 \pm 0.5 \\
4.7 \pm 0.6 \\
6.2 \pm 0.3 \\
1.61 \pm 0.15 \\
1.8 \pm 0.4\end{array}$ & $\begin{array}{r}12.35 \pm 0.25 \\
4.69 \pm 0.14 \\
6.2 \pm 0.05 \\
1.80 \pm 0.13 \\
1.78 \pm 0.2\end{array}$ \\
\hline 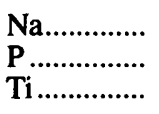 & $\begin{array}{l}\text { ICAP-AES } \\
\text { ICAP-AES } \\
\text { ICAP-AES }\end{array}$ & $\begin{array}{l}.31 \\
.12 \\
.77\end{array}$ & $\frac{.307}{-}$ & $\begin{array}{l}.313 \pm 0.02 \\
.101 \pm 0.018 \\
.71 \pm 0.05\end{array}$ & $\begin{array}{c}.295 \pm 0.023 \\
-\end{array}$ & $\begin{array}{c}.32 \pm 0.04 \\
.74 \pm 0.03\end{array}$ & $\begin{array}{c}.283 \pm 0.014 \\
.70 \pm 0.03\end{array}$ \\
\hline
\end{tabular}

' Values with no error listed are NIST information values; all others are NIST certified values.

\section{DISCUSSION}

NIST standard reference materials 1633 and 1633a were used as control standards for each determination. Each Argonne Premium Coal sample was run in triplicate (labeled 1,2, and 3) with the exception of UT PC-6, which was run in duplicate due to a lack of available sample. Data for these analyses are shown in tables 5 and 6 . The replicate analyses show the precision of the methods used. The relative percent standard deviation was generally about \pm 5 percent. Comparison of the analyses of these control standards with NIST certified values (NBS, 1975, 1979), with AAS values (Kane, 1989), and with values determined by instrumental neutron activation analysis (Ondov and others, 1975; Rowe and Steinnes, 1977) shows the accuracy of the methods (tables 7 and 8).

ICAP-AES in Reston of samples WY PC-2 and POC PC-5 determined lower concentrations of barium and stron- tium than other methods of analysis (see table 2 in paper by Palmer and Klizas, this volume). They were probably caused by incomplete dissolution of barium sulfate present in the sample. Low $\mathrm{Sr}$ results may have been caused by $\mathrm{Sr}$ co-precipitating with $\mathrm{Ba}$.

Sample IL PC-3 showed a wide concentration range for Ba $(420-540 \mu \mathrm{g} / \mathrm{g})$. Sample ND PC-8 showed low concentrations of potassium. These values were close to the detection limit, and that may account for the error. This also could be due to sampling error or incomplete digestion of barite that may be present in the sample.

Beryllium values determined by ICAP-AES were corrected for vanadium and titanium interferences, and zinc values determined by ICAP-AES were corrected for interferences by manganese, iron, and vanadium. Interference corrections vary depending on the instrument operating conditions used and should be determined before the start of the analysis. 
Table 8. Comparison of element concentrations in NIST standard reference material 1633a determined in this study with certified values and with concentrations determined in other studies.

[Concentrations for the first 14 elements are in micrograms per $\mathrm{gram}(\mu \mathrm{g} / \mathrm{g})$; others are in weight percent. Methods used in this study: ICAP-AES, inductively coupled argon plasma-atomic emission spectrometry; GFAAS, graphite furnace atomic absorption spectrometry; FAAS, flame atomic absorption spectrometry. NIST, National Institute of Standards and Technology, formerly the National Bureau of Standards (NBS). Certified and information values for NIST 1633a are from NBS (1979). - no data]

\begin{tabular}{|c|c|c|c|c|c|}
\hline \multirow{2}{*}{ Element } & \multicolumn{2}{|c|}{ This study } & \multirow{2}{*}{ NBS (1979)' } & \multirow{2}{*}{ Gladney and others (1987) } & \multirow{2}{*}{ Kane (1989) } \\
\hline & Method & Conc. & & & \\
\hline 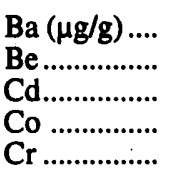 & $\begin{array}{l}\text { ICAP-AES } \\
\text { ICAP-AES } \\
\text { GFAAS } \\
\text { FAAS } \\
\text { ICAP-AES }\end{array}$ & $\begin{array}{l}1,400 \\
: 12 \\
46^{.94} \\
190\end{array}$ & $\begin{array}{c}1,500 \\
12 \\
1.0 \pm 0.15 \\
46 \\
196 \pm 6\end{array}$ & $\begin{aligned} 1,420 & \pm 100 \\
12.8 & \pm 0.6 \\
1.12 & \pm 0.17 \\
43 & \pm 3 \\
194 & \pm 7\end{aligned}$ & $\begin{array}{l}- \\
0.98 \pm 0.08 \\
- \\
-\end{array}$ \\
\hline 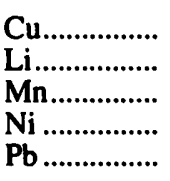 & $\begin{array}{l}\text { ICAP-AES } \\
\text { FAAS } \because \\
\text { ICAP-AES } \\
\text { ICAP-AES } \\
\text { GFAAS }\end{array}$ & $\begin{array}{r}110 \\
170 \\
180 \\
130 \\
71\end{array}$ & $\begin{array}{c}118 \pm 3 \\
- \\
179 \pm 8 \\
127 \pm 4 \\
72.4 \pm 0.4\end{array}$ & $\begin{array}{c}120 \pm 4 \\
165 \pm 50 \\
188 \pm 15 \\
124 \pm 13 \\
72 \pm 4\end{array}$ & $\begin{array}{c}114 \pm 7 \\
184 \pm 14 \\
160 \pm 12 \\
- \\
62 \pm 4\end{array}$ \\
\hline 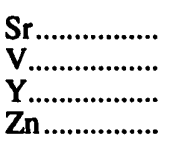 & $\begin{array}{l}\text { ICAP-AES } \\
\text { ICAP-AES } \\
\text { ICAP-AES } \\
\text { ICAP-AES }\end{array}$ & $\begin{array}{r}850 \\
290 \\
87 \\
210\end{array}$ & $\begin{array}{l}830 \pm 30 \\
297 \pm 6 \\
- \\
220 \pm 10\end{array}$ & $\begin{array}{c}810 \pm 40 \\
294 \pm 18 \\
82 \pm 6 \\
226 \pm 22\end{array}$ & $\frac{\bar{Z}}{211 \pm 11}$ \\
\hline 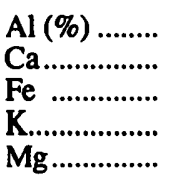 & $\begin{array}{l}\text { ICAP-AES } \\
\text { ICAP-AES } \\
\text { ICAP-AES } \\
\text { ICAP-AES } \\
\text { ICAP-AES }\end{array}$ & $\begin{array}{l}14.0 \\
1.14 \\
9.18 \\
1.95 \\
.44\end{array}$ & $\begin{array}{l}14.3 \pm 1.0 \\
1.11 \pm 0.01 \\
9.40 \pm 0.1 \\
1.88 \pm 0.06 \\
.455 \pm 0.01\end{array}$ & $\begin{array}{l}14.4 \pm 0.6 \\
1.14 \pm 0.06 \\
9.37 \pm 0.23 \\
1.88 \pm 0.05 \\
.457 \pm 0.045\end{array}$ & $\begin{array}{c}- \\
- \\
.436 \pm 0.005\end{array}$ \\
\hline $\begin{array}{l}\text { Na.............. } \\
\text { P ................. } \\
\text { Ti................ }\end{array}$ & $\begin{array}{l}\text { ICAP-AES } \\
\text { ICAP-AES } \\
\text { ICAP-AES }\end{array}$ & $\begin{array}{l}.17 \\
.18 \\
.92\end{array}$ & $\begin{array}{l}.17 \pm 0.01 \\
0.8\end{array}$ & $\begin{array}{l}.173 \pm 0.011 \\
.169 \pm 0.024 \\
.823 \pm 0.034\end{array}$ & $\begin{array}{c}.158 \pm 0.014 \\
-\end{array}$ \\
\hline
\end{tabular}

' Values with no error listed are NIST information values; all others are NIST certified values.

\section{REFERENCES}

Gladney, E.S., O'Malley, B.T., Roelandts, J., and Gills, T.E., 1987, Compilation of elemental concentration data for NBS clinical, biological, geological, and environmental standard reference materials: National Bureau of Standards Special Publication 260-111, p. 1633-1-1633-26, 1633a-1-1633a-14.

Kane, J.S., 1989, The determination of selected elements in coal ash by atomic absorption spectrometry in Golightly, D.W., and Simon, F.O., eds., Methods for sampling and inorganic analysis of coal: U.S. Geological Survey Bulletin 1823, p. 47-53.

National Bureau of Standards, 1975, National Bureau of Standards certificate of analysis, standard reference material 1633, trace elements in coal fly ash: Washington, D.C., National Bureau of Standards, 2 p.

1979, National Bureau of Standards certificate of analysis, standard reference material 1633a, trace elements in coal fly ash: Washington, D.C., National Bureau of Standards, 2 p.

Ondov, J.M., Zoller, W.H., Olmez, Ilham, Aras, N.K., Gordon, G.E., Rancitelli, L.A., Abel, K.H., Filby, R.H., Shah, K.R., and Ragaini, R.C., 1975, Elemental concentrations in the National Bureau of Standards' environmental coal and fly ash standard reference materials: Analytical Chemistry, v. 47, no. 7, p. 1102-1109.

Rowe, J.J., and Steinnes, E., 1977, Instrumental activation analysis of coal and fly ash with thermal and epithermal neutrons: Journal of Radioanalytical Chemistry, v. 37, no. 2, p. 849856. 


\title{
Determination of 25 Elements in Coal Ash from 8 Argonne Premium Coal Samples by Inductively Coupled Argon Plasma-Atomic Emission Spectrometry
}

\author{
By Paul H. Briggs
}

\begin{abstract}
Twenty-five major and trace elements were determined in coal ash material by inductively coupled argon plasmaatomic emission spectrometry (ICAP-AES). Two decomposition techniques were used. Coal ashes were analyzed in triplicate to determine the precision of the method. The National Institute of Standards and Technology (NIST), formerly the National Bureau of Standards (NBS), standard reference material 1632a and U.S. Geological Survey (USGS) standard reference material CLB-1 were used to assess the accuracy of the method.

\section{INTRODUCTION}

Inductively coupled argon plasma-atomic emission spectrometry (ICAP-AES) is rapidly becoming a common method to determine many major and trace elements in geologic materials. An overview of ICAP-AES analysis was given by Lichte and others (1987). Recently, the ICAP-AES method was expanded to include the analysis of coal by using an acid dissolution procedure (Doughten and Gillison, 1990). This work included new methods combining results from two different decomposition procedures that were used to determine the concentrations of 25 elements in coal ashes from 8 Argonne Premium Coal samples by ICAP-AES. Fourteen elements were determined by an acid decomposition using a mixture of hydrochloric, nitric, perchloric, and hydrofluoric acids at a low temperature in a method described by Crock and others (1983). Eleven additional elements were determined by a sodium peroxide sinter decomposition technique modified from one described by Borsier and Garcia (1983). The digested sample was aspirated into the ICAP discharge where the elemental emission signal was measured simultaneously for the elements of interest.
\end{abstract}

\section{EXPERIMENTAL}

All ICAP-AES measurements described in this paper were performed on a Thermo Jarrell-Ash model 1160 Plasma Atomcomp simultaneous instrument in the U.S. Geological Survey (USGS) laboratory in Denver, Colo. ICAP-AES calibration was performed using USGS reference material BHVO-1, Canadian Certified Reference Materials Project SY-3, and four multielement solutions. The wavelengths, operating ranges, and decomposition methods are given in table 1 . The ICAP-AES operating conditions are given in table 2.

Two decomposition procedures were used to determine the 25 elements. The acid decomposition technique was used for the determination of the trace elements $\mathrm{Be}, \mathrm{Co}, \mathrm{Cr}$, $\mathrm{Cu}, \mathrm{Li}, \mathrm{Mn}, \mathrm{Ni}, \mathrm{Sc}, \mathrm{Sr}, \mathrm{Th}, \mathrm{V}, \mathrm{Y}$, and $\mathrm{Zn}$ and the major element $\mathrm{Na}$. The trace-element suite was chosen in order to give the best reporting limits for the 100 -fold dilution and the ease of solubility by the acid decomposition. Sodium is reported with the trace suite because sodium peroxide was the sintering flux used for the sample decomposition for major-element determinations.

Coal ash sample solutions from the acid decomposition were prepared in the following manner: a $0.200-\mathrm{g}$ sample, to which a solution containing $100 \mu \mathrm{g}$ lutetium had been added as an internal standard, was digested and evaporated to dryness in a $30-\mathrm{mL}$ Teflon vessel with $3 \mathrm{~mL} \mathrm{HCl}, 2 \mathrm{~mL}$ $\mathrm{HNO}_{3}, 1 \mathrm{~mL} \mathrm{HClO}_{4}$, and $2 \mathrm{~mL} \mathrm{HF}$ at $110^{\circ} \mathrm{C}$. An additional $1 \mathrm{~mL} \mathrm{HClO}_{4}$ was added to the residue and taken to dryness again at $160^{\circ} \mathrm{C}$. One milliliter $\mathrm{HNO}_{3}$ and one drop 30 percent $\mathrm{H}_{2} \mathrm{O}_{2}$ were added to the residue, and $20 \mathrm{~mL}$ of 1 percent $\mathrm{HNO}_{3}$ was added to the solution. The solution was transferred to a $13 \times 100-\mathrm{mm}$ polypropylene test tube and capped until ready for ICAP-AES analysis. All reagents used in the procedures were reagent grade or better. It should be noted that this solution was used for both ICAP-AES and inductively coupled argon plasma-mass spectrometry (ICAP-MS) to minimize duplication of digestion and maximize the efforts of the laboratory staff. (See ICAP-MS analysis in Meier's paper in this volume.) 
Table 3. Concentrations of $\mathrm{Na}_{2} \mathrm{O}$ (in weight percent) and trace elements (in parts per million) in eight Argonne Premium Coal samples ashed and then digested by acid decomposition.

[Three analyses were done for each sample by ICAP-AES (inductively coupled argon plasma-atomic emission spectrometry)]

\begin{tabular}{|c|c|c|c|c|c|c|c|c|c|c|c|c|c|c|}
\hline Coal ash & $\mathrm{Na}_{2} \mathrm{O}$ & $\mathrm{Be}$ & Co & $\mathrm{Cr}$ & $\mathrm{Cu}$ & $\mathrm{Li}$ & $\mathrm{Mn}$ & $\mathrm{Ni}$ & Sc & Sr & Th & V & $\mathbf{Y}$ & $\mathrm{Zn}$ \\
\hline $\begin{array}{l}\text { UF PC- } 1-1 \ldots \ldots \ldots \\
\text { UF PC- } 1-2 \ldots \ldots \ldots \\
\text { UF PC- } 1-3 \ldots \ldots \ldots\end{array}$ & $\begin{array}{r}0.34 \\
.34 \\
.35\end{array}$ & $\begin{array}{l}11 \\
11 \\
11\end{array}$ & $\begin{array}{l}39 \\
39 \\
40\end{array}$ & $\begin{array}{l}160 \\
160 \\
160\end{array}$ & $\begin{array}{l}140 \\
140 \\
130\end{array}$ & $\begin{array}{l}110 \\
110 \\
110\end{array}$ & $\begin{array}{l}330 \\
330 \\
320\end{array}$ & $\begin{array}{l}110 \\
110 \\
110\end{array}$ & $\begin{array}{l}29 \\
29 \\
29\end{array}$ & $\begin{array}{l}430 \\
430 \\
430\end{array}$ & $\begin{array}{l}21 \\
21 \\
19\end{array}$ & $\begin{array}{l}200 \\
200 \\
200\end{array}$ & $\begin{array}{l}63 \\
60 \\
56\end{array}$ & $\begin{array}{l}140 \\
140 \\
140\end{array}$ \\
\hline $\begin{array}{l}\text { WY PC-2-1...... } \\
\text { WY PC-2-2...... } \\
\text { WY PC-2-3....... }\end{array}$ & $\begin{array}{l}1.9 \\
1.9 \\
1.9\end{array}$ & $\begin{array}{l}3 \\
3 \\
3\end{array}$ & $\begin{array}{l}18 \\
21 \\
20\end{array}$ & $\begin{array}{l}74 \\
76 \\
75\end{array}$ & $\begin{array}{l}150 \\
160 \\
160\end{array}$ & $\begin{array}{l}46 \\
46 \\
46\end{array}$ & $\begin{array}{l}240 \\
240 \\
220\end{array}$ & $\begin{array}{l}55 \\
57 \\
55\end{array}$ & $\begin{array}{l}19 \\
19 \\
20\end{array}$ & $\begin{array}{l}3,000 \\
3,000 \\
3,100\end{array}$ & $\begin{array}{l}16 \\
19 \\
15\end{array}$ & $\begin{array}{l}170 \\
170 \\
170\end{array}$ & $\begin{array}{l}42 \\
42 \\
43\end{array}$ & $\begin{array}{l}150 \\
130 \\
140\end{array}$ \\
\hline $\begin{array}{l}\text { IL PC-3-1 } \\
\text { IL PC-3-2 ........... } \\
\text { IL PC-3-3 .......... }\end{array}$ & $\begin{array}{l}.88 \\
.93 \\
.86\end{array}$ & $\begin{array}{l}4 \\
4 \\
4\end{array}$ & $\begin{array}{l}29 \\
27 \\
26\end{array}$ & $\begin{array}{l}300 \\
210 \\
210\end{array}$ & $\begin{array}{l}67 \\
69 \\
64\end{array}$ & $\begin{array}{l}46 \\
47 \\
46\end{array}$ & $\begin{array}{l}570 \\
520 \\
520\end{array}$ & $\begin{array}{l}180 \\
120 \\
120\end{array}$ & $\begin{array}{l}17 \\
17 \\
16\end{array}$ & $\begin{array}{l}190 \\
200 \\
190\end{array}$ & $\begin{array}{l}15 \\
13 \\
12\end{array}$ & $\begin{array}{l}240 \\
230 \\
220\end{array}$ & $\begin{array}{l}26 \\
26 \\
23\end{array}$ & $\begin{array}{l}1,100 \\
1,300 \\
1,200\end{array}$ \\
\hline $\begin{array}{l}\text { PITT PC-4-1 ..... } \\
\text { PITT PC-4-2 ..... } \\
\text { PITT PC-4-3.... }\end{array}$ & $\begin{array}{l}.50 \\
.50 \\
.49\end{array}$ & $\begin{array}{l}8 \\
8 \\
8\end{array}$ & $\begin{array}{l}28 \\
29 \\
28\end{array}$ & $\begin{array}{l}170 \\
170 \\
170\end{array}$ & $\begin{array}{l}59 \\
68 \\
62\end{array}$ & $\begin{array}{l}89 \\
90 \\
89\end{array}$ & $\begin{array}{l}230 \\
230 \\
220\end{array}$ & $\begin{array}{r}97 \\
100 \\
100\end{array}$ & $\begin{array}{l}27 \\
27 \\
27\end{array}$ & $\begin{array}{l}690 \\
700 \\
680\end{array}$ & $\begin{array}{l}19 \\
15 \\
17\end{array}$ & $\begin{array}{l}178 \\
180 \\
180\end{array}$ & $\begin{array}{l}43 \\
42 \\
43\end{array}$ & $\begin{array}{r}150 \\
88 \\
88\end{array}$ \\
\hline $\begin{array}{l}\text { POC PC-5-1 .... } \\
\text { POC PC-5-2 ..... } \\
\text { POC PC-5-3 .... }\end{array}$ & $\begin{array}{l}2.1 \\
2.1 \\
2.1\end{array}$ & $\begin{array}{l}15 \\
15 \\
15\end{array}$ & $\begin{array}{l}75 \\
73 \\
75\end{array}$ & $\begin{array}{l}190 \\
180 \\
180\end{array}$ & $\begin{array}{l}310 \\
310 \\
310\end{array}$ & $\begin{array}{l}100 \\
100 \\
110\end{array}$ & $\begin{array}{l}340 \\
340 \\
350\end{array}$ & $\begin{array}{l}140 \\
139 \\
140\end{array}$ & $\begin{array}{l}33 \\
34 \\
33\end{array}$ & $\begin{array}{l}2,100 \\
2,000 \\
2,100\end{array}$ & $\begin{array}{l}23 \\
20 \\
22\end{array}$ & $\begin{array}{l}230 \\
230 \\
230\end{array}$ & $\begin{array}{l}110 \\
110 \\
110\end{array}$ & $\begin{array}{l}100 \\
100 \\
100\end{array}$ \\
\hline $\begin{array}{l}\text { UT PC-6-1 ....... } \\
\text { UT PC-6-2 ........ } \\
\text { UT PC-6-3........ }\end{array}$ & $\begin{array}{l}3.9 \\
3.8 \\
3.8\end{array}$ & $\begin{array}{l}3 \\
3 \\
3\end{array}$ & $\begin{array}{l}21 \\
20 \\
20\end{array}$ & $\begin{array}{l}150 \\
110 \\
110\end{array}$ & $\begin{array}{l}94 \\
92 \\
89\end{array}$ & $\begin{array}{l}120 \\
120 \\
120\end{array}$ & $\begin{array}{l}93 \\
92 \\
89\end{array}$ & $\begin{array}{l}79 \\
74 \\
75\end{array}$ & $\begin{array}{l}17 \\
16 \\
16\end{array}$ & $\begin{array}{l}1,300 \\
1,300 \\
1,300\end{array}$ & $\begin{array}{l}13 \\
13 \\
12\end{array}$ & $\begin{array}{r}100 \\
96 \\
95\end{array}$ & $\begin{array}{l}45 \\
43 \\
43\end{array}$ & $\begin{array}{l}100 \\
110 \\
100\end{array}$ \\
\hline $\begin{array}{l}\text { WV PC-7-1...... } \\
\text { WV PC-7-2...... } \\
\text { WV PC-7-3...... }\end{array}$ & $\begin{array}{l}.24 \\
.24 \\
.24\end{array}$ & $\begin{array}{l}11 \\
11 \\
11\end{array}$ & $\begin{array}{l}38 \\
39 \\
38\end{array}$ & $\begin{array}{l}200 \\
200 \\
200\end{array}$ & $\begin{array}{l}110 \\
110 \\
110\end{array}$ & $\begin{array}{l}140 \\
144 \\
140\end{array}$ & $\begin{array}{l}71 \\
70 \\
72\end{array}$ & $\begin{array}{l}81 \\
84 \\
81\end{array}$ & $\begin{array}{l}38 \\
38 \\
38\end{array}$ & $\begin{array}{l}320 \\
320 \\
320\end{array}$ & $\begin{array}{l}32 \\
33 \\
34\end{array}$ & $\begin{array}{l}220 \\
220 \\
220\end{array}$ & $\begin{array}{l}63 \\
67 \\
62\end{array}$ & $\begin{array}{l}55 \\
54 \\
58\end{array}$ \\
\hline $\begin{array}{l}\text { ND PC-8-1 ....... } \\
\text { ND PC-8-2 ....... } \\
\text { ND PC-8-3 ....... }\end{array}$ & $\begin{array}{l}7.0 \\
7.0 \\
7.0\end{array}$ & $\begin{array}{l}2 \\
2 \\
2\end{array}$ & $\begin{array}{r}8 \\
10 \\
9\end{array}$ & $\begin{array}{l}23 \\
23 \\
26\end{array}$ & $\begin{array}{r}48 \\
51 \\
130\end{array}$ & $\begin{array}{l}28 \\
28 \\
28\end{array}$ & $\begin{array}{l}850 \\
870 \\
870\end{array}$ & $\begin{array}{l}14 \\
16 \\
15\end{array}$ & $\begin{array}{l}8 \\
8 \\
8\end{array}$ & $\begin{array}{l}5,200 \\
5,200 \\
5,200\end{array}$ & $\begin{array}{l}6 \\
8 \\
7\end{array}$ & $\begin{array}{l}41 \\
40 \\
41\end{array}$ & $\begin{array}{l}23 \\
24 \\
23\end{array}$ & $\begin{array}{l}54 \\
49 \\
50\end{array}$ \\
\hline
\end{tabular}


Table 4. Concentrations of major oxides (in weight percent) and trace elements (in parts per million) in eight Argonne Premium Coal samples ashed and then digested by sinter decomposition.

[Three analyses were done for each sample by ICAP-AES (inductively coupled argon plasma-atomic emission spectrometry)]

\begin{tabular}{|c|c|c|c|c|c|c|c|c|c|c|c|}
\hline Coal ash & $\mathrm{Al}_{2} \mathrm{O}_{3}$ & $\mathrm{CaO}$ & $\mathrm{Fe}_{2} \mathrm{O}_{3}$ & $\mathrm{~K}_{2} \mathrm{O}$ & MgO & $\mathrm{P}_{2} \mathrm{O}_{5}$ & $\mathrm{SiO}_{2}$ & $\mathrm{TiO}_{2}$ & B & $\mathbf{B a}$ & $\mathrm{Zr}$ \\
\hline $\begin{array}{l}\text { UF PC-1 } 1 \ldots \ldots \ldots \ldots \\
\text { UF PC- } 1-2 \ldots \ldots \ldots \ldots \\
\text { UF PC- } 1-3 \ldots \ldots \ldots \ldots\end{array}$ & $\begin{array}{l}21 \\
22 \\
23\end{array}$ & $\begin{array}{l}4.1 \\
4.2 \\
4.2\end{array}$ & $\begin{array}{l}17 \\
18 \\
18\end{array}$ & $\begin{array}{l}2.5 \\
2.7 \\
2.6\end{array}$ & $\begin{array}{l}0.92 \\
1.0 \\
.98\end{array}$ & $\begin{array}{r}0.10 \\
.10 \\
.10\end{array}$ & $\begin{array}{l}40 \\
41 \\
42\end{array}$ & $\begin{array}{r}0.89 \\
.92 \\
.96\end{array}$ & $\begin{array}{l}260 \\
230 \\
360\end{array}$ & $\begin{array}{l}390 \\
380 \\
470\end{array}$ & $\begin{array}{l}180 \\
180 \\
190\end{array}$ \\
\hline $\begin{array}{l}\text { WY PC-2-1 ........ } \\
\text { WY PC-2-2 ....... } \\
\text { WY PC-2-3 ........ }\end{array}$ & $\begin{array}{l}14 \\
14 \\
16\end{array}$ & $\begin{array}{l}17 \\
16 \\
19\end{array}$ & $\begin{array}{l}5.2 \\
5.9 \\
5.8\end{array}$ & $\begin{array}{l}.38 \\
.50 \\
.54\end{array}$ & $\begin{array}{l}3.8 \\
3.8 \\
4.4\end{array}$ & $\begin{array}{l}.57 \\
.56 \\
.67\end{array}$ & $\begin{array}{l}25 \\
26 \\
28\end{array}$ & $\begin{array}{r}.95 \\
.97 \\
1.1\end{array}$ & $\begin{array}{l}1,000 \\
1,300 \\
1,100\end{array}$ & $\begin{array}{l}3,300 \\
3,400 \\
3,600\end{array}$ & $\begin{array}{l}210 \\
220 \\
230\end{array}$ \\
\hline $\begin{array}{l}\text { IL PC-3-1 } \ldots \ldots \ldots \ldots . . \\
\text { IL PC-3-2 } \ldots \ldots \ldots \ldots . . \\
\text { IL PC-3-3 } \ldots \ldots \ldots \ldots \ldots\end{array}$ & $\begin{array}{l}16 \\
15 \\
14\end{array}$ & $\begin{array}{l}8.3 \\
8.1 \\
7.5\end{array}$ & $\begin{array}{l}21 \\
22 \\
20\end{array}$ & $\begin{array}{l}1.7 \\
1.6 \\
1.6\end{array}$ & $\begin{array}{l}.80 \\
.77 \\
.70\end{array}$ & $\begin{array}{l}.06 \\
.05 \\
.04\end{array}$ & $\begin{array}{l}41 \\
40 \\
36\end{array}$ & $\begin{array}{l}.74 \\
.73 \\
.66\end{array}$ & $\begin{array}{r}1,000 \\
1,000 \\
970\end{array}$ & $\begin{array}{l}510 \\
480 \\
530\end{array}$ & $\begin{array}{l}170 \\
140 \\
120\end{array}$ \\
\hline $\begin{array}{l}\text { PITT PC-4-1....... } \\
\text { PITT PC-4-2....... } \\
\text { PITT PC-4-3........ }\end{array}$ & $\begin{array}{l}20 \\
20 \\
19\end{array}$ & $\begin{array}{l}2.8 \\
2.8 \\
2.9\end{array}$ & $\begin{array}{l}19 \\
19 \\
19\end{array}$ & $\begin{array}{l}1.5 \\
1.5 \\
1.5\end{array}$ & $\begin{array}{l}.60 \\
.60 \\
.59\end{array}$ & $\begin{array}{l}.23 \\
.22 \\
.22\end{array}$ & $\begin{array}{l}42 \\
42 \\
41\end{array}$ & $\begin{array}{l}.93 \\
.92 \\
.89\end{array}$ & $\begin{array}{l}520 \\
530 \\
510\end{array}$ & $\begin{array}{l}420 \\
420 \\
410\end{array}$ & $\begin{array}{l}200 \\
200 \\
190\end{array}$ \\
\hline $\begin{array}{l}\text { POC PC }-5-1 \ldots \ldots . . \\
\text { POC PC-5-2 ....... } \\
\text { POC PC }-5-3 \ldots \ldots \ldots\end{array}$ & $\begin{array}{l}21 \\
20 \\
20\end{array}$ & $\begin{array}{l}12 \\
12 \\
12\end{array}$ & $\begin{array}{l}14 \\
13 \\
13\end{array}$ & $\begin{array}{l}.83 \\
.82 \\
.72\end{array}$ & $\begin{array}{l}1.8 \\
1.7 \\
1.7\end{array}$ & $\begin{array}{l}.10 \\
.10 \\
.09\end{array}$ & $\begin{array}{l}31 \\
30 \\
29\end{array}$ & $\begin{array}{l}1.3 \\
1.2 \\
1.2\end{array}$ & $\begin{array}{l}260 \\
240 \\
240\end{array}$ & $\begin{array}{l}4,100 \\
3,800 \\
3,800\end{array}$ & $\begin{array}{l}320 \\
300 \\
290\end{array}$ \\
\hline $\begin{array}{l}\text { UT PC-6-........... } \\
\text { UT PC-6-2 ........... } \\
\text { UT PC-6-3........... }\end{array}$ & $\begin{array}{l}15 \\
16 \\
16\end{array}$ & $\begin{array}{l}12 \\
13 \\
13\end{array}$ & $\begin{array}{l}9.0 \\
9.1 \\
9.6\end{array}$ & $\begin{array}{l}.70 \\
.73 \\
.76\end{array}$ & $\begin{array}{l}1.0 \\
1.1 \\
1.1\end{array}$ & $\begin{array}{l}.04 \\
.04 \\
.03\end{array}$ & $\begin{array}{l}41 \\
43 \\
44\end{array}$ & $\begin{array}{l}.85 \\
.85 \\
.89\end{array}$ & $\begin{array}{l}2,700 \\
2,700 \\
2,900\end{array}$ & $\begin{array}{l}710 \\
730 \\
800\end{array}$ & $\begin{array}{l}360 \\
390 \\
370\end{array}$ \\
\hline $\begin{array}{l}\text { WV PC-7-1 ......... } \\
\text { WV PC-7-2 ........ } \\
\text { WV PC-7-3 ........ }\end{array}$ & $\begin{array}{l}30 \\
33 \\
31\end{array}$ & $\begin{array}{l}.40 \\
.44 \\
.42\end{array}$ & $\begin{array}{l}3.0 \\
2.9 \\
2.8\end{array}$ & $\begin{array}{l}2.9 \\
3.3 \\
3.0\end{array}$ & $\begin{array}{l}.70 \\
.77 \\
.72\end{array}$ & $\begin{array}{l}.09 \\
.09 \\
.09\end{array}$ & $\begin{array}{l}53 \\
59 \\
55\end{array}$ & $\begin{array}{l}1.9 \\
2.1 \\
2.0\end{array}$ & $\begin{array}{l}200 \\
400 \\
360\end{array}$ & $\begin{array}{l}570 \\
740 \\
620\end{array}$ & $\begin{array}{l}340 \\
380 \\
350\end{array}$ \\
\hline $\begin{array}{l}\text { ND PC-8-1 } \\
\text { ND PC- } 8-2 \ldots \ldots \ldots \ldots \\
\text { ND PC }-8-3 \ldots \ldots \ldots \ldots . .\end{array}$ & $\begin{array}{l}7.9 \\
7.9 \\
7.8\end{array}$ & $\begin{array}{l}21 \\
21 \\
21\end{array}$ & $\begin{array}{l}6.7 \\
7.0 \\
6.9\end{array}$ & $\begin{array}{l}.56 \\
.41 \\
.45\end{array}$ & $\begin{array}{l}6.1 \\
6.2 \\
6.1\end{array}$ & $\begin{array}{l}.30 \\
.30 \\
.29\end{array}$ & $\begin{array}{l}15 \\
15 \\
15\end{array}$ & $\begin{array}{l}.32 \\
.32 \\
.31\end{array}$ & $\begin{array}{l}830 \\
850 \\
830\end{array}$ & $\begin{array}{l}5,500 \\
5,600 \\
5,600\end{array}$ & $\begin{array}{l}120 \\
140 \\
120\end{array}$ \\
\hline
\end{tabular}


Table 5. Concentrations of $\mathrm{Na}_{2} \mathrm{O}$ (in weight percent) and trace elements (in parts per million) in two coal reference materials ashed and then digested by acid decomposition.

[USGS, U.S. Geological Survey; ICAP-AES, inductively coupled argon plasma-atomic emission spectrometry; NIST, National Institute of Standards and Technology, formerly the National Bureau of Standards]

\begin{tabular}{|c|c|c|c|c|}
\hline & \multicolumn{2}{|c|}{ USGS CLB-1 } & \multicolumn{2}{|c|}{ NIST $1632 a$} \\
\hline & $\begin{array}{l}\text { This study, } \\
\text { ICAP-AES }\end{array}$ & $\begin{array}{c}\text { J.S. Kane } \\
\text { (USGS, unpub. } \\
\text { data, 1990) })^{1.2}\end{array}$ & $\begin{array}{l}\text { This study, } \\
\text { ICAP-AES }\end{array}$ & $\begin{array}{l}\text { Gladney } \\
\text { and others } \\
(1984)^{1,2}\end{array}$ \\
\hline $\begin{array}{l}\mathrm{Na} a_{2} \mathrm{O}(\%) \ldots . . . \\
\mathrm{Be}(\mathrm{ppm}) . . . . . \\
\mathrm{Co}(\mathrm{ppm}) . . . . \\
\mathrm{Cr}(\mathrm{ppm}) . . . . . \\
\mathrm{Cu}(\mathrm{ppm}) . . . .\end{array}$ & $\begin{array}{l}0.28 \\
14 \\
91 \\
130 \\
140\end{array}$ & $\begin{array}{c}0.31 \\
16 \\
87 \\
130 \\
140\end{array}$ & $\begin{array}{l}0.48 \\
5 \\
29 \\
150 \\
68\end{array}$ & $\begin{array}{c}0.48 \\
6 \\
27 \\
150 \\
70\end{array}$ \\
\hline $\begin{array}{l}\mathrm{Li}(\mathrm{ppm}) \ldots . . . \\
\mathrm{Mn}(\mathrm{ppm}) \\
\mathrm{Ni}(\mathrm{ppm}) . . . \\
\mathrm{Sc}(\mathrm{ppm}) . . . \\
\mathrm{Sr}(\mathrm{ppm})\end{array}$ & $\begin{array}{r}85 \\
110 \\
250 \\
27 \\
880\end{array}$ & $\begin{array}{r}110 \\
120 \\
250 \\
25 \\
930\end{array}$ & $\begin{array}{r}130 \\
120 \\
79 \\
27 \\
370\end{array}$ & $\begin{array}{r}150 \\
130 \\
85 \\
27 \\
380\end{array}$ \\
\hline $\begin{array}{l}\text { Th }(\mathrm{ppm}) \ldots . . . \\
\mathrm{V}(\mathrm{ppm}) . . . . . . \\
\mathrm{Y}(\mathrm{ppm}) \ldots . . . . \\
\mathrm{Zn}(\mathrm{ppm}) . . . . . \\
\% \text { ash ........... }\end{array}$ & $\begin{array}{c}20 \\
160 \\
64 \\
660 \\
7.8\end{array}$ & $\begin{array}{r}18 \\
160 \\
58 \\
660\end{array}$ & $\begin{array}{c}20 \\
180 \\
34 \\
120 \\
23.5\end{array}$ & $\begin{array}{r}19 \\
190 \\
34 \\
120\end{array}$ \\
\hline
\end{tabular}

'Reported on a whole-coal basis and converted to an ash basis for comparison.

${ }^{2}$ Compilation of data obtained by various methods.

\section{REFERENCES}

Borsier, M., and Garcia, M., 1983, Analyse automatique d'echantillons geologiques par plasma ICP: Spectrochimica Acta, v. 38B, nos. 1/2, p. 123-127.

Crock, J.G., Lichte, F.E., and Briggs, P.H., 1983, Determination of elements in National Bureau of Standards' geological reference materials SRM 278 obsidian and SRM 688 basalt by inductively coupled argon plasma-atomic emission spectrometry: Geostandards Newsletter, v. 7, no. 2, p. 335-340.

Doughten, M.W., and Gillison, J.R., 1990, Determination of selected elements in whole coal and in coal ash from the eight
Table 6. Concentrations of major oxides (in weight percent) and trace elements (in parts per million) in two coal reference materials ashed and then digested by sinter decomposition.

[USGS, U.S. Geological Survey; ICAP-AES, inductively coupled argon plasma-atomic emission spectrometry; NIST, National Institute of Standards and Technology, formerly the National Bureau of Standards]

\begin{tabular}{|c|c|c|c|c|}
\hline & \multicolumn{2}{|c|}{ USGS CLB-1 } & \multicolumn{2}{|c|}{ NIST 1632a } \\
\hline & $\begin{array}{l}\text { This study, } \\
\text { ICAP-AES }\end{array}$ & $\begin{array}{c}\text { J.S. Kane } \\
\text { (USGS, unpub. } \\
\text { data, 1990) }^{1,2}\end{array}$ & $\begin{array}{l}\text { This study, } \\
\text { ICAP-AES }\end{array}$ & $\begin{array}{c}\text { Gladney } \\
\text { and others } \\
(1984)^{1.2}\end{array}$ \\
\hline $\begin{array}{l}\mathrm{Al}_{2} \mathrm{O}_{3}(\%) \ldots . . \\
\mathrm{CaO}(\%) \ldots . . . \\
\mathrm{Fe}_{2} \mathrm{O}_{3}(\%) \ldots . . \\
\mathrm{K}_{2} \mathrm{O}(\%) \ldots \ldots \\
\mathrm{MgO}(\%) \ldots . .\end{array}$ & $\begin{array}{l}18 \\
2.6 \\
14 \\
.87 \\
.53\end{array}$ & $\begin{array}{l}19 \\
2.9 \\
16 \\
.96 \\
.62\end{array}$ & $\begin{array}{c}23 \\
1.4 \\
6.6 \\
2.1 \\
.70\end{array}$ & $\begin{array}{c}24 \\
1.4 \\
6.8 \\
2.1 \\
.85\end{array}$ \\
\hline $\begin{array}{l}\mathrm{P}_{2} \mathrm{O}_{5}(\%) \ldots . . . \\
\mathrm{SiO}_{2}(\%) \ldots \ldots . \\
\mathrm{TiO}_{2}(\%) \ldots . . . \\
\mathrm{B}(\mathrm{ppm}) \ldots . . . . \\
\mathrm{Ba}(\mathrm{ppm}) \ldots . .\end{array}$ & $\begin{array}{l}30.89 \\
82^{.91} \\
430\end{array}$ & $4_{470}^{36^{.98}}$ & $\begin{array}{l}53^{.22} \\
1.1 \\
220^{.1} \\
440\end{array}$ & $\begin{array}{l}55^{.25} \\
1.2 \\
230 \\
530\end{array}$ \\
\hline $\begin{array}{l}\mathrm{Zr}(\mathrm{ppm}) . . . . \\
\% \text { ash ........... }\end{array}$ & $\begin{array}{l}170 \\
7.8\end{array}$ & 160 & $\begin{array}{l}230 \\
23.5\end{array}$ & 230 \\
\hline
\end{tabular}

'Reported on a whole-coal basis and converted to an ash basis for comparison.

${ }^{2}$ Compilation of data obtained by various methods.

Argonne Premium Coal samples by atomic absorption spectrometry, atomic emission spectrometry and ion selective electrode: Energy and Fuels, v. 4, no. 5, p. 426-430.

Gladney, E.S., Burns, C.E., Perrin, D.R., Roelandts, I., and Gills, T.E., 1984, 1982 compilation of elemental concentration data for NIST biological, geological, and environmental standard reference materials: National Bureau of Standards Special Publication 260-88, p. 21.

Lichte, F.E., Golightly, D.W., and Lamothe, P.J., 1987, Inductively coupled plasma-atomic emission spectrometry, in Baedecker, P.A., ed., Methods for geochemical analysis: U.S. Geological Survey Bulletin 1770, p. B1-B10. 


\title{
Determination of 33 Elements in Coal Ash from 8 Argonne Premium Coal Samples by Inductively Coupled Argon Plasma-Mass Spectrometry
}

\author{
By Allen L. Meier
}

\begin{abstract}
Thirty-three elements were determined in the ash of eight Argonne Premium Coal samples by inductively coupled argon plasma-mass spectrometry (ICAP-MS). Two sample digestion procedures were used, a sodium peroxide sinter to dissolve resistant minerals and an acid digestion technique for acid-soluble minerals in the coal ash. Hf, Ta, $\mathrm{W}$, and the rare earth elements $\mathrm{La}, \mathrm{Ce}, \mathrm{Pr}, \mathrm{Nd}, \mathrm{Sm}, \mathrm{Eu}, \mathrm{Gd}$, $\mathrm{Tb}, \mathrm{Dy}, \mathrm{Ho}$. Er, Tm, and Yb were determined by ICAP-MS in the solution from the sodium peroxide sinter. $\mathrm{Ga}, \mathrm{Ge}, \mathrm{As}$, $\mathrm{Rb}, \mathrm{Nb}, \mathrm{Mo}, \mathrm{Ag}, \mathrm{Cd}, \mathrm{Sn}, \mathrm{Sb}, \mathrm{Te}, \mathrm{Cs}, \mathrm{Au}, \mathrm{Tl}, \mathrm{Pb}, \mathrm{Bi}$, and U were determined by ICAP-MS in the acid solution. These solutions were also used for inductively coupled argon plasma-atomic emission spectrometry (ICAP-AES) determination of other elements to give nearly total elemental coverage except for the volatile elements, halogens, and elements not retained because of combustion in the ashing process. The technique to determine the value for each element was selected to provide the best possible precision and determination limit while minimizing interferences.
\end{abstract}

\section{INTRODUCTION}

Inductively coupled argon plasma-mass spectrometry (ICAP-MS) is one of the newest instrumental analytical techniques to be used for elemental determination in geologic materials. The U.S. Geological Survey (USGS) began use of the technique in 1985 and developed methods using ICAP-MS for the determination of rare earth elements (REE's) and platinum-group elements and for the analysis of coal. ICAP-MS is attractive for these applications because it has multielement measurement capabilities with very low detection limits. Most elements are detected directly in solutions in the range of 1 to $100 \mathrm{pg} / \mathrm{mL}$. These detection limits are often 100 to 1,000 times lower than those routinely achieved by inductively coupled argon plasma-atomic emission spectrometry (ICAP-AES). The response is linear with concentration over about 6 to 8 orders of magnitude, making calibration quite uncomplicated. Another advantage of ICAP-MS is that the mass spectra of elements are relatively simple. Problems with the techniques arise from spectral interferences from molecular species and effects from the sample matrix. These problems are minimized by the use of corrections for spectral overlaps and internal standards for matrix effects. For the analysis of coal, ICAP-MS and ICAP-AES are used as complementary techniques. ICAP-AES is used to determine the elements that normally have higher concentrations in the coal ash. These are primarily the lower mass elements where the ICAP-MS technique has more interferences. The ICAP-AES technique is also used for other elements that are normally found in coal ash above the detection limits for the technique and where the precision by this technique is better than the precision of the ICAP-MS technique. ICAPMS is used to determine the elements where a lower limit of detection is necessary to determine normal concentrations found in coal and for elements where the ICAP-AES technique suffers from interferences.

\section{EXPERIMENTAL}

\section{SINTER METHOD}

Hf, Ta, W, and the rare earth elements $\mathrm{La}, \mathrm{Ce}, \mathrm{Pr}, \mathrm{Nd}$, $\mathrm{Sm}, \mathrm{Eu}, \mathrm{Gd}, \mathrm{Tb}, \mathrm{Dy}, \mathrm{Ho}, \mathrm{Er}, \mathrm{Tm}$, and $\mathrm{Yb}$ are made soluble in a $0.1-\mathrm{g}$ coal ash sample by sintering with sodium peroxide, leaching with water, and acidifying with nitric acid in a preparation technique modified from one described by Borsier and Garcia (1983). Details of the procedure are described by Briggs in this volume. The elements were then determined by ICAP-MS at lower reporting limits, in parts per million, of $2.0 \mathrm{La}, 3.0 \mathrm{Ce}, 0.5 \mathrm{Pr}, 2.0 \mathrm{Nd}, 0.5 \mathrm{Sm}, 0.2$ $\mathrm{Eu}, 1.0 \mathrm{Gd}, 0.5 \mathrm{~Tb}, 0.2 \mathrm{Dy}, 0.5 \mathrm{Ho}, 0.2 \mathrm{Er}, 0.5 \mathrm{Tm}, 0.5 \mathrm{Yb}$, $1.0 \mathrm{Hf}, 1.0 \mathrm{Ta}$, and $1.0 \mathrm{~W}$. Lutetium was added as an internal standard to correct for instrument instability and oxide interferences. Two-point calibration for each element was made by using the average intensity of five blanks taken 
through the entire procedure, and the intensities were acquired on a solution of a glass reference standard containing a known concentration of each element. The standard solution was run at 15 sample intervals, drift was calculated, and correction was applied between standards. All new determinations reported in this paper result from work done in the USGS laboratory in Denver, Colo.

\section{INTERFERENCES FOR THE SINTER METHOD}

Isobaric interferences of some metal oxide ions are quite high for selected REE's. Therefore, conditions that minimize the oxide ions were used. The delivery line from the nebulizer spray chamber to the plasma torch was cooled to $10^{\circ} \mathrm{C}$ to reduce the amount of water vapor (the main source of oxygen) that enters the plasma. Compromise conditions of power and the sheath gas flow rate were selected to achieve a balance between sensitivity and oxide. A method modified from Lichte and others (1987) was used to minimize and correct for these oxide isobaric overlaps. Oxide interference was subtracted by using the ratio of oxide ions to element ions in single-element standards and the oxide/ion ratio of the internal standard. In a 3-hour period of running samples, the oxide ratios can drift by as much as 100 percent. This is probably due to a gradual closing of the sampler cone, although several factors are involved. The oxide correction of PrO on gadolinium-157 must be very accurate. Even after the oxide abundance is minimized, a 10 percent error in the oxide ratio correction can result in a 20 percent error in the gadolinium result. The metal oxide/metal ion ratios of the REE's all responded similarly to plasma conditions (Lichte and others, 1987). Lutetium, used as an internal standard, was also used to track the drift in the oxide/metal satio through a sample run. The oxide ratios of overlapping elements were measured in standard solutions and compared to the $\mathrm{LuO}^{+} / \mathrm{Lu}^{+}$response. These ratios were used to mathematically subtract the oxide interference and to correct for changes in the other metal oxide ratios due to matrix or drift in the sample run.

\section{ACID DIGESTION METHOD}

$\mathrm{Ga}, \mathrm{Ge}, \mathrm{As}, \mathrm{Rb}, \mathrm{Nb}, \mathrm{Mo}, \mathrm{Ag}, \mathrm{Cd}, \mathrm{Sn}, \mathrm{Sb}, \mathrm{Te}, \mathrm{Cs}, \mathrm{Au}$, $\mathrm{Tl}, \mathrm{Pb}, \mathrm{Bi}$, and $\mathrm{U}$ were made soluble in a $0.2 \mathrm{-g}$ coal ash sample by heating with a mixture of hydrochloric, nitric, perchloric, and hydrofluoric acids (Crock and others, 1983). Details of the procedure are described by Briggs in this volume. The elements were then determined by ICAP-MS at lower reporting limits, in parts per million, of $0.1 \mathrm{Ga}, 0.5$ $\mathrm{Ge}, 1.0 \mathrm{As}, 0.5 \mathrm{Rb}, 2.0 \mathrm{Nb}, 0.5 \mathrm{Mo}, 0.5 \mathrm{Ag}, 0.2 \mathrm{Cd}, 1.0 \mathrm{Sn}$,
0.5 Sb, 0.5 Te, U.1 Cs, 0.1 Au, 0.5 Tl, 2.0 Pb, 0.1 Bi, and 0.2 $U$. Lutetium and indium were added as internal standards to correct for instrument instability and oxide interferences. Two-point calibration for each element was made by using the average intensity of five blanks taken through the entire procedure, and the intensities were acquired on a solution of a glass reference standard containing a known concentration of each element. The standard solution was run at 15 sample intervals, drift was calculated, and correction was applied between standards. Oxide interference was subtracted by using the ratio of oxide ions to element ions in singleelement standards and the oxide/ion ratio of the internal standard.

\section{INTERFERENCES FOR THE ACID DIGESTION METHOD}

Interferences in ICAP-MS come from matrix effects, instrumental drift, and isobaric overlap of some elemental isotopes and molecular ions formed in the plasma, resulting in suppression or enhancement of measured ion intensity. An internal standard was added to minimize matrix effects and instrumental drift. The isotopes measured were selected to minimize isobaric overlap from other elements and molecular species that might be present. Oxide overlaps were subtracted by measuring the ratio of oxide to element for single-element standards in each run and applying this ratio to each sample.

\section{RESULTS AND DISCUSSION}

The values obtained for triplicate analyses of the eight Argonne Premium Coal reference samples digested using the sinter method are given in table 1 . The values obtained for triplicate analyses of the eight Argonne Premium Coal reference samples prepared by using the acid digestion method are given in table 2.

The wide elemental coverage and the low limits of determination of the ICAP-MS technique make it a worthwhile tool for the analysis of coal ash. The accuracy and precision of the methods are adequate for the determination of trace elements in coal ash. Tables 3-6 show values determined by ICAP-MS on solutions obtained by the two dissolution methods of the ash of National Institute of Standards and Technology (NIST) reference standard materials $1632 \mathrm{~b}$ (coal) and 1633a (coal fly ash). The tables compare values obtained in this study with the reference values. These comparisons show that reasonable accuracy is achieved by these methods. Unfortunately, many elements determined have not been reported for these reference materials, so accuracy 


\begin{tabular}{|c|c|c|c|c|c|c|c|c|}
\hline 3 & mōo & 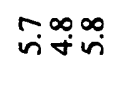 & $\simeq \cong=$ & ååa & สํㅇ & $==ニ$ & $\stackrel{n}{\infty} \stackrel{b}{\infty}^{\infty}$ & 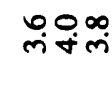 \\
\hline 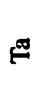 & $\stackrel{9}{0}$ & nᄈ̛̣ & บ= & さュさ & $\tilde{\sim} \bar{i}$ & צבּבָּב & 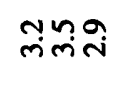 & $\bar{v} \bar{v} \bar{v}$ \\
\hline 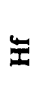 & O̊日ి & $\stackrel{0}{i} \stackrel{\circ}{\infty}_{\infty}^{+}$ & ヴナテ & gavon & $==0$ & $=m \simeq$ & $\cong \cong エ$ & $\stackrel{M}{*} \underset{+}{*} \dot{q}$ \\
\hline 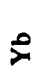 & $\begin{array}{l}n \infty \infty \\
\text { ที丶 }\end{array}$ & $\stackrel{\infty}{m \sim \mathcal{F}} \tilde{\sim} \tilde{\sim}$ & 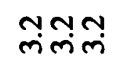 & 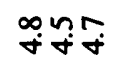 & $\begin{array}{l}0 \\
\text { ஸ்ó }\end{array}$ & 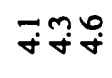 & 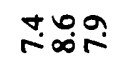 & 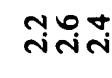 \\
\hline$g$ & 을 & 꾺 & ஸ் & ran & بـ & 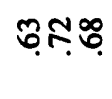 & $\dddot{i} \underset{-}{ }$ & ññ \\
\hline 氖 & 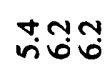 & Fُ户 & نై & F̊ํ & $\stackrel{m}{=} 0$ & 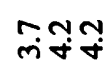 & 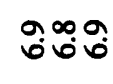 & ํㅗㄲ \\
\hline 오 & 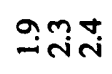 & بِ & ヘฺ๐్ & Ion & भुवेले & m‡t & กึก & ケ゚下 \\
\hline बे & 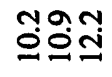 & $\stackrel{+}{\sim} \dot{m}_{\infty}^{\infty} \underset{\infty}{\infty}$ & 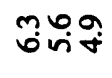 & $\vec{\infty}+\infty \infty$ & సีర్సేవ & 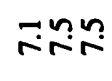 & 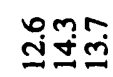 & miñ \\
\hline 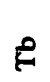 & تِ & พฺฺฺฺ & 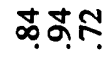 & Nִฒִ & 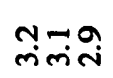 & =9ָ & ด్తిస్ & กำำ \\
\hline కౌ & 오 & & 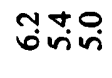 & 我華 & 유유 & $\stackrel{\substack{\infty \\
\sim \infty}}{\Delta}$ & エニニ & $\begin{array}{l}\forall \rightarrow \infty \\
\text { min }\end{array}$ \\
\hline 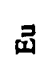 & ¿゙ં & $\stackrel{\infty}{-9} \underset{-}{1}$ & 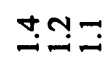 & $\stackrel{\infty}{-} \underset{i}{ }$ & تO요 & 오오 & 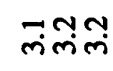 & ทำกั \\
\hline 星 & ชับู & må & ดัต์ & ă $\sigma_{\infty}^{\infty} \infty$ & פू் & 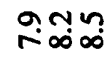 & 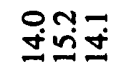 & ๙on \\
\hline $\bar{z}$ & nี่ที่ก & タチタ & "ాల్లి & ஙチす & ঠ్ర๙ః & ษ\%? & テ்ֻ & อニュ \\
\hline \pm & 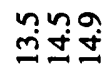 & 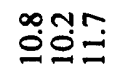 & $\begin{array}{l}\infty \\
\infty \\
\infty\end{array}$ & 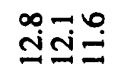 & 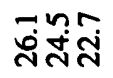 & $\stackrel{+}{=} \overrightarrow{\mathbf{I}}$ & 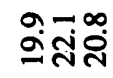 & भُণ̛ \\
\hline ن & పేి & ホஃ8ర & 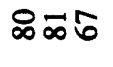 & 툐 & สิสุํํ & ล์ฮ์ & 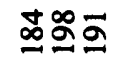 & ケタテ \\
\hline 9 & กร8\% & F甘心 & ర్లిల్లి & 츤요 & 봉ㅇㅇ & ถีทัทั & ஃสু & สี๋ี \\
\hline 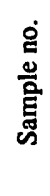 & 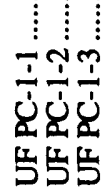 & 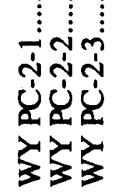 & 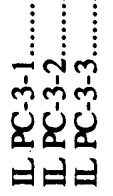 & 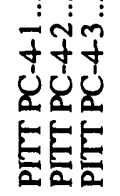 & 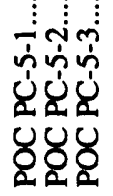 & 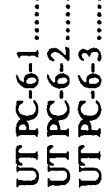 & 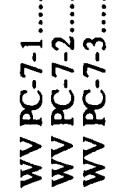 & 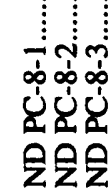 \\
\hline
\end{tabular}




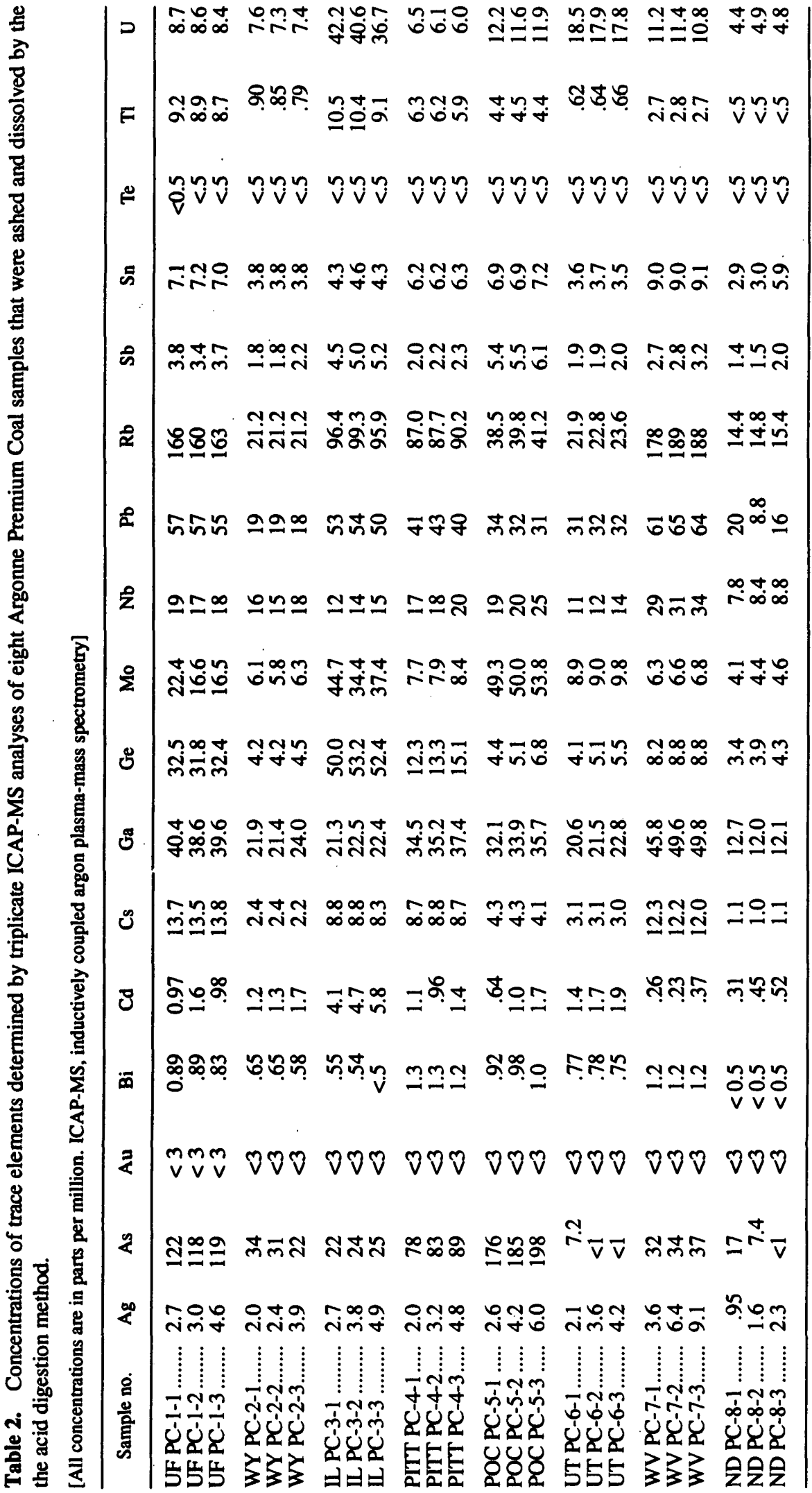


Table 3. Comparison of reference values with mean concentrations of trace elements determined by 23 replicate ICAP-MS analyses of NIST standard reference material $1632 \mathrm{~b}$ (coal) that was ashed and dissolved by the acid digestion method.

[All concentrations are in parts per million (ppm). The reference values for NIST standard reference material $1632 \mathrm{~b}$ (coal) are from National Bureau of Standards (1985). ICAP-MS, inductively coupled argon plasma-mass spectrometry; NIST, National Institute of Standards and Technology, formerly the National Bureau of Standards; RSD, relative standard deviation (in percent); STD, standard deviation (in parts per million); - , no data]

\begin{tabular}{|c|c|c|c|c|}
\hline \multirow{2}{*}{ Element } & \multirow{2}{*}{$\begin{array}{c}\text { Ref. } \\
\text { value } \\
\text { (ppm) }\end{array}$} & \multicolumn{3}{|c|}{ This study } \\
\hline & & $\begin{array}{l}\text { Mean } \\
\text { (ppm) }\end{array}$ & $\begin{array}{l}\text { STD } \\
(\mathrm{ppm})\end{array}$ & $\begin{array}{l}\text { RSD } \\
(\%)\end{array}$ \\
\hline $\begin{array}{l}\text { Ag.................. } \\
\text { As .................. } \\
\text { Au................. } \\
\text { Bi................... } \\
\text { Cd................. }\end{array}$ & $\begin{array}{l}\overline{54.7} \\
- \\
-\end{array}$ & $\begin{array}{l}1.7 \\
63 \\
<3.0 \\
1.7 \\
1.1\end{array}$ & $\begin{array}{l}1.3 \\
4.2 \\
.2 \\
.3\end{array}$ & $\begin{array}{r}75 \\
7 \\
14 \\
28\end{array}$ \\
\hline $\begin{array}{l}\mathrm{Cs} . \ldots . \ldots \ldots \ldots . . . . \\
\text { Ga.................. } \\
\text { Ge................. } \\
\text { Mo................. } \\
\text { Nb................. }\end{array}$ & $\frac{6.5}{\frac{13.2}{-}}$ & $\begin{array}{l}6.0 \\
44 \\
33 \\
13 \\
24\end{array}$ & $\begin{array}{r}1.4 \\
3.1 \\
4.5 \\
.5 \\
1.3\end{array}$ & $\begin{array}{r}24 \\
7 \\
13 \\
4 \\
5\end{array}$ \\
\hline 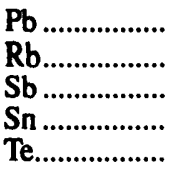 & $\begin{array}{l}54.0 \\
74.3 \\
- \\
-\end{array}$ & $\begin{array}{l}63 \\
75 \\
3.6 \\
9.5 \\
<.5\end{array}$ & $\begin{array}{r}8.2 \\
21.2 \\
.3 \\
.5 \\
-\end{array}$ & $\begin{array}{r}13 \\
28 \\
8 \\
5 \\
\end{array}$ \\
\hline Tl & $\overline{6.4}$ & $\begin{array}{l}2.3 \\
6.6\end{array}$ & $\begin{array}{l}.3 \\
.6\end{array}$ & $\begin{array}{r}12 \\
8\end{array}$ \\
\hline
\end{tabular}

Table 4. Comparison of reference values with mean concentrations of trace elements determined by 23 replicate ICAP-MS analyses of NIST standard reference material 1633 a (coal fly ash) that was dissolved by the acid digestion method.

[All concentrations are in parts per million (ppm). The reference values for NIST standard reference material 1633a (coal fly ash) are from National Bureau of Standards (1979). ICAP-MS, inductively coupled argon plasma-mass spectrometry; NIST, National Institute of Standards and Technology, formerly the National Bureau of Standards; RSD, relative standard deviation (in percent); STD, standard deviation (in parts per million); -, no data]

\begin{tabular}{|c|c|c|c|c|}
\hline \multirow{2}{*}{ Element } & \multirow{2}{*}{$\begin{array}{c}\text { Ref. } \\
\text { value } \\
\text { (ppm) }\end{array}$} & \multicolumn{3}{|c|}{ This study } \\
\hline & & $\begin{array}{l}\text { Mean } \\
\text { (ppm) }\end{array}$ & $\begin{array}{c}\text { STD } \\
\text { (ppm) }\end{array}$ & $\begin{array}{l}\text { RSD } \\
\text { (\%) }\end{array}$ \\
\hline 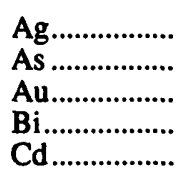 & $\frac{145}{-}$ & $\begin{array}{c}2.3 \\
172 \\
<3.0 \\
1.3 \\
1.2\end{array}$ & $\begin{array}{l}1.7 \\
9.1 \\
.2 \\
.2\end{array}$ & $\begin{array}{r}76 \\
5 \\
13 \\
15\end{array}$ \\
\hline $\begin{array}{l}\text { Cs } \ldots \ldots \ldots \ldots . . . . . \\
\text { Ga ................. } \\
\text { Ge ................ } \\
\text { Mo ................ } \\
\text { Nb................. }\end{array}$ & $\begin{array}{l}11 \\
58 \\
33.9 \\
29 \\
-\end{array}$ & $\begin{array}{l}10 \\
65 \\
39 \\
35 \\
30\end{array}$ & $\begin{array}{l}1.9 \\
5.3 \\
2.5 \\
1.0 \\
2.5\end{array}$ & $\begin{array}{r}19 \\
8 \\
6 \\
3 \\
8\end{array}$ \\
\hline 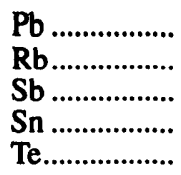 & $\begin{array}{c}72.4 \\
131 \\
6.8 \\
10 \\
-\end{array}$ & $\begin{array}{c}83 \\
148 \\
7.3 \\
9.2 \\
<.5\end{array}$ & $\begin{array}{r}7.4 \\
30.7 \\
.5 \\
.7 \\
\end{array}$ & $\begin{array}{r}9 \\
21 \\
7 \\
7 \\
-\end{array}$ \\
\hline T1 & $\begin{array}{r}5.7 \\
10.2\end{array}$ & 12 & $\begin{array}{l}.6 \\
.9\end{array}$ & $\begin{array}{l}9 \\
8\end{array}$ \\
\hline
\end{tabular}


Table 5. Comparison of reference values with mean concentrations of rare earth and other elements determined by 22 replicate ICAP-MS analyses of NIST standard reference material $1632 \mathrm{~b}$ (coal) that was ashed and dissolved by the sinter method.

[All concentrations are in parts per million (ppm). The reference values for NIST standard reference material $1632 \mathrm{~b}$ (coal) are from National Bureau of Standards (1985). ICAP-MS, inductively coupled argon plasma-mass spectrometry; NIST, National Institute of Standards and Technology, formerly the National Bureau of Standards; RSD, relative standand deviation (in percent); STD, standard deviation (in parts per million); - , no data]

\begin{tabular}{|c|c|c|c|c|}
\hline \multirow{2}{*}{ Element } & \multirow{2}{*}{$\begin{array}{c}\text { Ref. } \\
\text { value } \\
\text { (ppm) }\end{array}$} & \multicolumn{3}{|c|}{ This study } \\
\hline & & $\begin{array}{l}\text { Mean } \\
(\mathrm{ppm})\end{array}$ & $\begin{array}{c}\text { STD } \\
\text { (ppm) }\end{array}$ & $\begin{array}{l}\text { RSD } \\
(\%)\end{array}$ \\
\hline $\begin{array}{l}\text { La............... } \\
\text { Ce.................. } \\
\text { Pr.................. } \\
\text { Nd ................. } \\
\text { Sm............... }\end{array}$ & $\begin{array}{c}75.0 \\
132.4 \\
- \\
\overline{12.8}\end{array}$ & $\begin{array}{r}64.3 \\
124.6 \\
13.6 \\
53.2 \\
10.9\end{array}$ & $\begin{array}{r}3.11 \\
7.18 \\
.73 \\
2.98 \\
.65\end{array}$ & $\begin{array}{l}4.8 \\
5.8 \\
5.4 \\
5.6 \\
6.0\end{array}$ \\
\hline $\begin{array}{l}\text { Eu................. } \\
\text { Gd ................ } \\
\text { Tb................. } \\
\text { Dy ................ } \\
\text { Ho ................ }\end{array}$ & $\frac{2.5}{-}$ & $\begin{array}{r}2.5 \\
10.2 \\
1.5 \\
9.4 \\
1.7\end{array}$ & $\begin{array}{l}.19 \\
.84 \\
.11 \\
.57 \\
.11\end{array}$ & $\begin{array}{l}7.5 \\
8.3 \\
7.0 \\
6.1 \\
6.4\end{array}$ \\
\hline 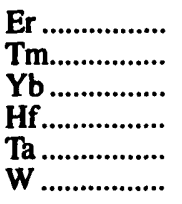 & $\begin{array}{l}\overline{-} \\
\frac{6}{7.3} \\
7.1\end{array}$ & $\begin{array}{r}5.3 \\
.8 \\
5.0 \\
6.8 \\
2.0 \\
6.8\end{array}$ & $\begin{array}{l}.36 \\
.07 \\
.37 \\
.55 \\
.24 \\
.51\end{array}$ & $\begin{array}{r}6.8 \\
8.6 \\
7.5 \\
8.1 \\
12.1 \\
7.5\end{array}$ \\
\hline
\end{tabular}

cannot be estimated using these materials. Precision is given as standard deviation and relative standard deviation for each element determined in the reference materials. For most elements, precision is better than 10 percent relative standard deviation. Precision for some elements is poorer, especially as detection limits are approached. Silver concentrations determined on solutions obtained by the acid digestion method have the most variation. The lack of precision can be attributed to sampling variation as well as instrumental variation.

\section{REFERENCES}

Borsier, M., and Garcia, M., 1983, Analyse automatique d'echantillons geologiques par plasma ICP: Spectrochimica Acta, v. $38 \mathrm{~B}$, nos. $1 / 2$, p. $123-127$.
Table 6. Comparison of reference values with mean concentrations of rare earth and other elements determined by 22 replicate ICAP-MS analyses of NIST standard reference material 1633 a (coal fly ash) that was dissolved by the sinter method.

[All concentrations are in parts per million (ppm). The reference values for NIST standard reference material 1633a (coal fly ash) are from National Bureau of Standards (1979). ICAP-MS, inductively coupled argon plasma-mass spectrometry; NIST, National Institute of Standards and Technology, formerly the National Bureau of Standards; RSD, relative standard deviation (in percent); STD, standard deviation (in parts per million); - , no data]

\begin{tabular}{|c|c|c|c|c|}
\hline \multirow{2}{*}{ Element } & \multirow{2}{*}{$\begin{array}{c}\text { Ref. } \\
\text { value } \\
\text { (ppm) }\end{array}$} & \multicolumn{3}{|c|}{ This study } \\
\hline & & $\begin{array}{l}\text { Mean } \\
\text { (ppm) }\end{array}$ & $\begin{array}{c}\text { STD } \\
\text { (ppm) }\end{array}$ & $\begin{array}{l}\text { RSD } \\
(\%)\end{array}$ \\
\hline $\begin{array}{l}\text { La............... } \\
\text { Ce................. } \\
\text { Pr .................. } \\
\text { Nd .................. } \\
\text { Sm................ }\end{array}$ & $\begin{array}{c}\overline{180.0} \\
- \\
-\end{array}$ & $\begin{array}{r}87.30 \\
168.12 \\
19.16 \\
75.71 \\
16.34\end{array}$ & $\begin{array}{r}5.28 \\
12.36 \\
1.32 \\
4.91 \\
.82\end{array}$ & $\begin{array}{l}6.0 \\
7.4 \\
6.9 \\
6.5 \\
5.0\end{array}$ \\
\hline $\begin{array}{l}\text { Eu................ } \\
\text { Gd ................ } \\
\text { Tb................ } \\
\text { Dy ................. } \\
\text { Ho ................ }\end{array}$ & $\frac{4.0}{-}$ & $\begin{array}{r}3.97 \\
16.16 \\
2.51 \\
15.48 \\
2.88\end{array}$ & $\begin{array}{r}.22 \\
1.52 \\
.18 \\
1.04 \\
.16\end{array}$ & $\begin{array}{l}5.7 \\
9.4 \\
7.1 \\
6.7 \\
5.5\end{array}$ \\
\hline 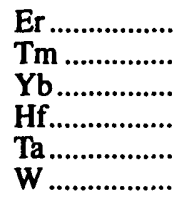 & $\begin{array}{l}- \\
\overline{7} \\
\overline{-} \\
-\end{array}$ & $\begin{array}{l}8.51 \\
1.22 \\
7.65 \\
8.09 \\
2.14 \\
6.11\end{array}$ & $\begin{array}{l}.44 \\
.08 \\
.46 \\
.82 \\
.19 \\
.52\end{array}$ & $\begin{array}{r}5.1 \\
6.7 \\
6.0 \\
10.2 \\
9.0 \\
8.5\end{array}$ \\
\hline
\end{tabular}

Crock, J.G., Lichte, F.E., and Briggs, P.H., 1983, Determination of elements in National Bureau of Standards' geological reference materials SRM 278 obsidian and SRM 688 basalt by inductively coupled argon plasma-atomic emission spectrometry: Geostandards Newsletter, v. 7, no. 2, p. 335-340.

Lichte, F.E., Meier, A.L., and Crock, J.G., 1987, Determination of the rare-earth elements in geological materials by inductively coupled plasma mass spectrometry: Analytical Chemistry, v. 59 , no. 8, p. $1150-1157$.

National Bureau of Standards, 1979, National Bureau of Standards certificate of analysis, standard reference material 1633a, trace elements in coal fly ash: Washington, D.C., National Bureau of Standards, $2 \mathrm{p}$.

-1985, National Bureau of Standards certificate of analysis, standard reference material $1632 \mathrm{~b}$, trace elements in coal (bituminous): Gaithersburg, Md., National Bureau of Standards, $5 \mathrm{p}$. 


\title{
Determination of Mercury and Selenium in Eight Argonne Premium Coal Samples by Cold-Vapor and Hydride-Generation Atomic Absorption Spectrometry
}

\author{
By Richard M. O'Leary
}

\begin{abstract}
The methods for the determination of mercury and selenium in whole coal by cold-vapor atomic absorption spectrometry (CVAAS) and hydride-generation atomic absorption spectrometry (HGAAS) are described. The Argonne Premium Coal samples were analyzed in triplicate to determine the precision of the method. The averaged values ranged from 0.01 to $0.39 \mu \mathrm{g} / \mathrm{g}$ for mercury and 0.60 to $6.2 \mu \mathrm{g} / \mathrm{g}$ for selenium. Mercury and selenium were also determined in standard reference materials from the National Institute of Standards and Technology (NIST), the Community Bureau of Reference (BCR) of the Commission of the European Communities, the National Research Council of Canada (NRCC), and the U.S Geological Survey (USGS). Results obtained by these methods were compared with the published values to determine the accuracy of the methods.
\end{abstract}

\section{INTRODUCTION}

Analytical techniques for the determination of mercury and selenium in coal are increasing in importance. With the passage of the 1990 Clean Air Act Amendments (CAAA), the Environmental Protection Agency (EPA) has been given the authority to set emission standards for a number of potentially hazardous air pollutants (HAP's) generated by a number of specific combustion sources. Mercury, selenium, and nine other elements present in coal are among the 189 pollutants identified as air toxins in the CAAA legislation. Although their concentrations in coal are minor, they represent a potentially significant release of mercury and selenium to the environment because of the large tonnage of coal burned in powerplants.

The most common instrumental technique for determining mercury is cold-vapor atomic absorption spectrometry (CVAAS). Some CVAAS techniques preconcentrate the mercury using a gold amalgam, then thermally release the mercury by inductively heating the gold; however, alternative techniques analyze the mercury vapor directly. Other instrumental techniques include graphite furnace atomic absorption spectroscopy (GFAAS), cold-vapor atomic fluorescence spectroscopy (CVAFS), and neutron activation analysis (NAA). Various sample preparation procedures include oxygen bomb combustion, direct coal combustion, microwave digestion, and hotplate acid digestion.

In the procedure described here, a $0.150-\mathrm{g}$ coal sample was decomposed by a heated mixture of nitric and sulfuric acids and vanadium pentoxide. The sample solution was introduced to a continuous-flow CVAAS system, where it was complexed and reduced with a solution of hydroxylamine hydrochloride and sodium chloride prior to further reduction with stannous chloride. The mercury vapor was then separated from the liquid in the phase separator before entering the quartz cell for the determination of the mercury concentration.

Like mercury, selenium can be determined by a number of different instrumental techniques such as GFAAS, NAA, and hydride-generation atomic absorption spectrometry (HGAAS). Of the AAS techniques, hydride generation is the technique of choice because it is relatively interference free as compared to GFAAS.

In the method used in this study, a $0.100-\mathrm{g}$ sample of pulverized coal was digested at $150-200^{\circ} \mathrm{C}$ with a mixture of concentrated sulfuric, nitric, and perchloric acids until a clear to yellow solution was reached. After the addition of 6 $\mathrm{M}$ hydrochloric acid, the solution was allowed to set to permit the selenium to reduce the $\mathrm{Se}^{+3}$ state. The diluted solution was then introduced by way of an autosampler and peristaltic pump to a Varian VGA-76 hydride generator coupled to an atomic absorption spectrophotometer. The sample solution was then mixed with concentrated hydrochloric acid and 0.35 percent sodium borohydride, and the resultant selenium hydride was then transported with argon gas to an air-acetylene flame-heated quartz cell for atomization and estimation of the selenium concentration. 


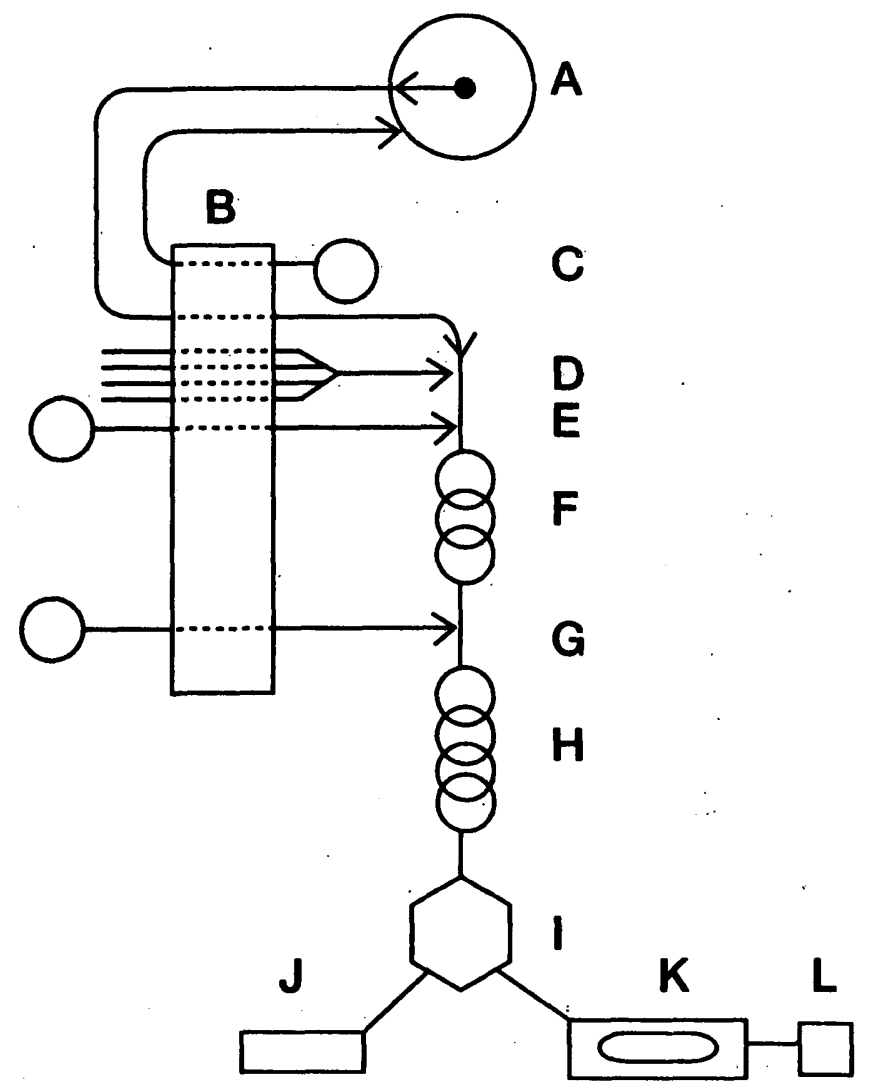

Figure 1. Continuous-flow cold-vapor atomic absorption spectrometry (CVAAS) manifold for determining mercury. A, Autosampler, $8 \mathrm{~mL} / \mathrm{min}$; B, 8-channel peristaltic pump; C, 1 percent nitric acid wash, $7 \mathrm{~mL} / \mathrm{min} ; \mathrm{D}$, air, $48 \mathrm{~mL} / \mathrm{min} ; \mathrm{E}$, complexing-reducing solution, $3.5 \mathrm{~mL} / \mathrm{min} ; \mathrm{F}, 20$-tum mixing coil; G, stannous chloride solution, $3.5 \mathrm{~mL} / \mathrm{min}$; H, 80-turn mixing coil; I, liquid-gas separator; J, liquid to waste; K, flow-through cell in atomic absorption spectrophotometer, $\mathrm{L}$, strip chart recorder.

\section{PROCEDURE FOR MERCURY}

Approximately (scooped) $0.1 \mathrm{~g}$ vanadium pentoxide,, 1.2 $1.5 \mathrm{~mL}$ concentrated sulfuric acid, and $3.5 \mathrm{~mL}$ concentrated nitric acid were added to $0.150 \mathrm{~g}$ of whole coal in a $16 \times 150$ $\mathrm{mm}$ disposable test tube and mixed. The test tube was placed in an aluminum heating block and covered with a watch glass. The temperature was ramped gradually to $150^{\circ} \mathrm{C}$ over a 2 -hour period. The tube was heated overnight at this temperature and then removed and allowed to cool. The sample was diluted to $15 \mathrm{~mL}$ with water, capped, and shaken for 5 minutes. It was then centrifuged at $1,000 \mathrm{rpm}$ (revolutions per minute) for 5 minutes, and approximately

\footnotetext{
1 Unless otherwise noted, all chemicals used in the mercury determinations are of Baker "Instra Analyzed" quality or are labeled "Suitable for mercury determinations," and the water is deionized.

${ }^{2}$ Some brands of vanadium pentoxide (reagent grade) contain trace amounts of mercury and need to be roasted at $500^{\circ} \mathrm{C}$ prior to use.
}

Table 1. Operating conditions for determination of mercury and selenium by cold-vapor atomic absorption spectrometry (CVAAS) and hydride-generation AAS (HGAAS), respectively.

\begin{tabular}{|c|c|c|}
\hline & $\mathrm{Hg}$ & $\mathrm{Se}$ \\
\hline 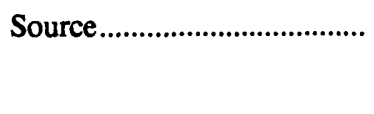 & $\begin{array}{l}\text { Hg hollow } \\
\text { cathode lamp. }\end{array}$ & $\begin{array}{l}\text { Electrodeless } \\
\text { discharge } \\
\text { lamp (EDL). }\end{array}$ \\
\hline Slit & $0.7 \mathrm{~nm}$ & $0.7 \mathrm{~nm}$ \\
\hline 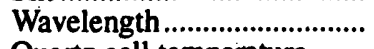 & $253.7 \mathrm{~nm}$ & $196.0 \mathrm{~nm}$ \\
\hline Quartz cell temperature ........ & $100^{\circ} \mathrm{C}$ & $2,000^{\circ} \mathrm{C}$ \\
\hline Mode .......................................... & Absorbance & Absorbance \\
\hline 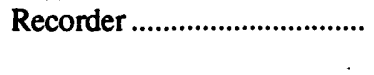 & $\underset{\min }{2 \mathrm{mV}, 5 \mathrm{~mm} /}$ & $\begin{array}{l}10 \mathrm{mV}, 5 \mathrm{~mm} / \\
\min \end{array}$ \\
\hline $\begin{array}{l}\text { AA recorder mode .............. } \\
\text { Sensitivity (peak height)...... }\end{array}$ & $\begin{array}{l}\text { TC3 } \\
1 \mu \mathrm{g} / \mathrm{L}=19 \mathrm{~mm}\end{array}$ & $\begin{array}{l}\text { TC3 } \\
10 \mu \mathrm{g} / \mathrm{L}=72 \mathrm{~mm}\end{array}$ \\
\hline
\end{tabular}

$12 \mathrm{~mL}$ of solution was transferred to a $16 \times 100-\mathrm{mm}$ disposable test tube.

The mercury was determined by using a continuousflow-through CVAAS system (fig. 1) as described by Kennedy and Crock (1987). The test tube containing the sample solution was placed in the autosampler. The sample solution was fed from the autosampler by a peristaltic pump into a continuous-flow system, where it was mixed with a reducing-complexing solution of 3 percent hydroxylamine hydrochloride (reagent grade) and 3 percent sodium chloride (reagent grade) in 10 percent sulfuric acid. Next, the sample was further reduced with a 10 percent stannous chloride in 10 percent hydrochloric acid. The sample then entered a phase separator where the mercury gas passed through the flow-through cell of the AAS for measurement and the liquid was discharged to waste. The absorbance indicating the mercury concentration was recorded on a strip chart, and peak heights were measured. The operating conditions for the AAS are shown in table 1.

The samples were compared against a calibration curve generated by analyzing standards in the $1-$ to $15-\mu \mathrm{g} / \mathrm{L}$ range. The calibration standards were made by dilution of a $1.47-\mu \mathrm{g} / \mathrm{mL}$ mercury solution (standard reference material (SRM) 1641c) obtained from NIST (National Institute of Standards and Technology). The calibration standards contained a final concentration of $3.7 \mathrm{M}$ nitric acid, $1.8 \mathrm{M}$ sulfuric acid, and 0.5 percent ( $w / v$, weight per volume) sodium dichromate (reagent grade).

\section{PROCEDURE FOR SELENIUM}

The method used for determining selenium is a modification of that described by Aruscavage (1977). Twenty milliliters of concentrated hydrochloric acid ${ }^{3}$ and $2 \mathrm{~mL}$ concentrated sulfuric acid were added to $0.100 \mathrm{~g}$ of whole coal !

\footnotetext{
${ }^{3}$ Unless otherwise noted, all chemicals used in the selenium determinations are Baker "Instra Analyzed" or of equal purity, and the water is deionized.
} 


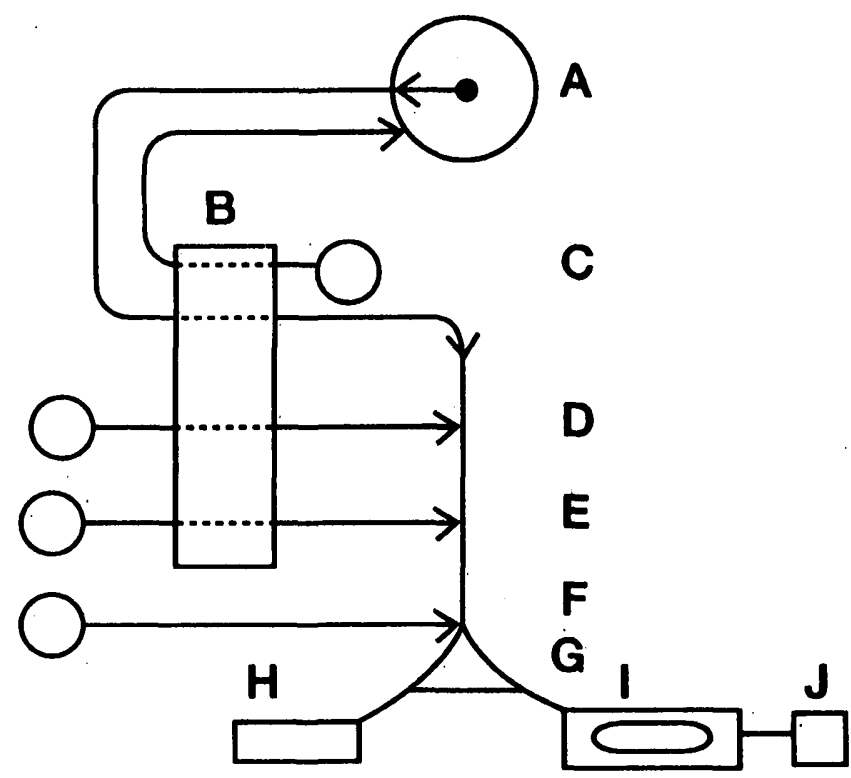

Figure 2. Continuous-flow hydride-generation atomic absorption spectrometry (HGAAS) manifold for determining selenium. A, Autosampler, $8 \mathrm{~mL} / \mathrm{min}$; B, 4-channel peristaltic pump; C, deionized water wash, $8 \mathrm{~mL} / \mathrm{min} ; \mathrm{D}$, concentrated hydrochloric acid, $1 \mathrm{~mL} / \mathrm{min}$; E, sodium borohydride solution, $1 \mathrm{~mL} / \mathrm{min} ; \mathrm{F}$, nitrogen purge gas, $90 \mathrm{~mL} / \mathrm{min} ; \mathrm{G}$, liquid-gas phase separator, $\mathbf{H}$, liquid to waste; I, heated quartz fumace in atomic absorption spectrophotometer; $J$, strip chart recorder.

in a $250-\mathrm{mL}$ Erlenmeyer flask. After the mixture was allowed to stand overnight, $3 \mathrm{~mL}$ of perchloric acid (redistilled) was added. A claw refluxer was added to the flask, and the solution was heated on a hotplate at $150-200^{\circ} \mathrm{C}$ for 30 minutes. The refluxers were removed, and heating of the solution was continued until the development of dense white fumes and a clear to yellow solution. The solution then was removed from the hotplate. When the solution was cool, $25 \mathrm{~mL}$ of $6 \mathrm{M}$ hydrochloric acid was added, and the solution was allowed to stand for $\mathbf{3 0}$ minutes to permit the selenium to reduce to the $\mathrm{Se}^{+3}$ state. The contents of the flask were transferred to a $60-\mathrm{mL}$ polyethylene bottle and diluted to $55 \mathrm{~g}$ with water.

The selenium was determined by the HGAAS system using a Varian VGA-76 hydride generator coupled to a Perkin-Elmer atomic absorption spectrophotometer (fig. 2). The solution was transferred to $13 \times 100-\mathrm{mm}$ test tubes and placed in an autosampler. The sample solution was then fed from the autosampler to the hydride-generation system by a peristaltic pump, where it was mixed with concentrated hydrochloric acid and 0.35 percent sodium borohydride. The selenium hydride was then transported with argon gas to the air-acetylene flame-heated quartz furnace of the AAS for atomization. The absorbance indicating the selenium concentration was registered on a strip chart recorder, and peak heights were measured. The operating conditions for the AAS are shown in table 1.
Table 2. Mercury $(\mathrm{Hg})$ and selenium $(\mathrm{Se})$ contents in eight Argonne Premium Coals determined by cold-vapor and hydridegeneration atomic absorption spectrometry (CVAAS and HGAAS), respectively.

[All values in micrograms per gram $(\mu \mathrm{g} / \mathrm{g}$ )]

\begin{tabular}{|c|c|c|c|c|}
\hline \multirow{2}{*}{ Sample ID } & \multicolumn{3}{|c|}{ Hg, CVAAS } & \multirow{2}{*}{$\begin{array}{c}\text { Se, } \\
\text { HGAAS }\end{array}$} \\
\hline & 1st day & 2d day & Average & \\
\hline $\begin{array}{r}\text { UF PC-1-1 ........ } \\
\text { UF PC-1-2 ....... } \\
\text { UF.PC-1-3 ........ } \\
\text { Average......... }\end{array}$ & $\begin{array}{r}0.38 \\
.37 \\
.44 \\
-\end{array}$ & $\begin{array}{r}0.39 \\
.40 \\
.37 \\
\end{array}$ & $\overline{-}$ & $\begin{array}{l}2.3 \\
2.0 \\
1.5 \\
1.9\end{array}$ \\
\hline $\begin{array}{r}\text { WY PC-2-1...... } \\
\text { WY PC-2-2 ....... } \\
\text { WY PC-2-3...... } \\
\text { Average......... }\end{array}$ & $\begin{array}{l}.13 \\
.12 \\
.11 \\
-\end{array}$ & $\begin{array}{l}.11 \\
.13 \\
.14 \\
-\end{array}$ & $\overline{-}$ & $\begin{array}{l}1.8 \\
2.8 \\
2.5 \\
2.4\end{array}$ \\
\hline $\begin{array}{l}\text { IL PC-3-1.......... } \\
\text { IL PC-3-2.......... } \\
\text { IL PC-3-3.......... } \\
\text { Average......... }\end{array}$ & $\begin{array}{l}.09 \\
.10 \\
.09 \\
-\end{array}$ & $\begin{array}{l}.10 \\
.08 \\
.09 \\
-\end{array}$ & $\overline{-}$ & $\begin{array}{l}4.1 \\
4.0 \\
4.3 \\
4.1\end{array}$ \\
\hline $\begin{array}{r}\text { PITT PC-4-1 ..... } \\
\text { PITT PC-4-2.... } \\
\text { PITT PC-4-3 ..... } \\
\text { Average......... }\end{array}$ & $\begin{array}{l}.15 \\
.17 \\
.15 \\
-\end{array}$ & $\begin{array}{l}.16 \\
.17 \\
.16 \\
-\end{array}$ & $\frac{-}{16}$ & $\begin{array}{l}1.8 \\
1.6 \\
1.6 \\
1.7\end{array}$ \\
\hline $\begin{array}{l}\text { POC PC-5-1..... } \\
\text { POC PC-5-2..... } \\
\text { POC PC-5-3..... } \\
\text { Average......... }\end{array}$ & $\begin{array}{l}.06 \\
.06 \\
.06 \\
-\end{array}$ & $\begin{array}{l}.06 \\
.06 \\
.05 \\
-\end{array}$ & $\overline{-}$ & $\begin{array}{l}2.9 \\
2.9 \\
3.1 \\
3.0\end{array}$ \\
\hline $\begin{array}{r}\text { UT PC-6-1 ......... } \\
\text { UT PC-6-2 ........ } \\
\text { UT PC-6-3 ......... } \\
\text { Average......... }\end{array}$ & $\begin{array}{l}.02 \\
.01 \\
.01 \\
-\end{array}$ & $\begin{array}{l}.01 \\
.01 \\
.01 \\
-\end{array}$ & $\overline{-}$ & $\begin{array}{l}1.2 \\
1.3 \\
1.3 \\
1.3\end{array}$ \\
\hline $\begin{array}{r}\text { WV PC-7-1 ...... } \\
\text { WV PC-7-2...... } \\
\text { WV PC-7-3...... } \\
\text { Average......... }\end{array}$ & $\begin{array}{l}.08 \\
.07 \\
.10 \\
-\end{array}$ & $\begin{array}{l}.08 \\
.08 \\
.10 \\
-\end{array}$ & $\bar{z}$ & $\begin{array}{l}6.1 \\
5.6 \\
6.9 \\
6.2\end{array}$ \\
\hline $\begin{array}{c}\text { ND PC-8-1........ } \\
\text { ND PC-8-2........ } \\
\text { ND PC-8-3........ } \\
\text { Average......... }\end{array}$ & $\begin{array}{l}.08 \\
.08 \\
.07 \\
-\end{array}$ & $\begin{array}{l}.08 \\
.08 \\
.08 \\
\end{array}$ & $\overline{\bar{z}}$ & $\begin{array}{l}.60 \\
.60 \\
.60 \\
.60\end{array}$ \\
\hline
\end{tabular}

The samples were compared against a calibration curve generated by analyzing standards in the $5-$ to $20-\mu \mathrm{g} / \mathrm{L}$ range. The calibration standards were made by dilution of a commercially prepared $10-\mu \mathrm{g} / \mathrm{g}$ selenium standard in 10 percent $\mathrm{HCl}$. The calibration standards contained a final concentration of $3 \mathrm{M}$ hydrochloric acid and $0.72 \mathrm{M}$ sulfuric acid.

\section{DISCUSSION}

The eight Argonne Premium Coal samples were analyzed for selenium in triplicate on one day and for mercury in triplicate on two nonconsecutive days. All analyses were performed in the U.S. Geological Survey laboratory in Denver, Colo. The averaged values for mercury range from 0.01 to $0.39 \mu \mathrm{g} / \mathrm{g}$, and the averaged values for selenium range from 0.60 to $6.2 \mu \mathrm{g} / \mathrm{g}$ as shown in table 2. As a measure of 
Table 3. Comparison of recommended values of mercury concentrations in standard reference materials with mean concentrations determined in this study by cold-vapor atomic absorption spectrometry (CVAAS).

[Column headings: RV, recommended value of mercury concentration from the references A-E; SDEV, standard deviation; \%RSD, relative standard deviation, in percent; $\% \mathrm{R}$, percent recovery, which compares the values obtained by CVAAS in this study with the recommended values; $\mu \mathrm{g} / \mathrm{g}$, micrograms per gram. Sources: NIST, U.S. National Institute of Standards and Technology, formerly the National Bureau of Standards (NBS); NRCC, National Research Council of Canada; USGS, U.S. Geological Survey; BCR, Community Bureau of Reference of the Commission of the European Communities. References: A, Lengyel and others, 1994; B, NBS, 1974; C, NBS, 1978a; D, Govindaraju, 1989; E, Griepink and others, 1986]

\begin{tabular}{|c|c|c|c|c|c|c|c|c|}
\hline \multirow[b]{2}{*}{ Standard } & \multirow[b]{2}{*}{ Source } & \multirow[b]{2}{*}{ Reference } & \multirow[b]{2}{*}{ Description } & \multirow{2}{*}{$\underset{(\mu \mathrm{g} / \mathrm{g})}{\mathrm{RV}}$} & \multicolumn{3}{|c|}{ This study, CVAAS } & \multirow[b]{2}{*}{$\% R$} \\
\hline & & & & & $\begin{array}{l}\text { Mean } \\
(\mu g / g)\end{array}$ & $\begin{array}{l}\text { SDEV } \\
(\mu g / g)\end{array}$ & \%RSD & \\
\hline 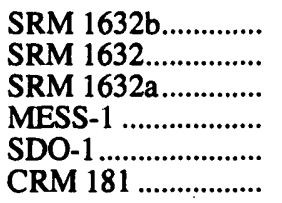 & $\begin{array}{l}\text { NIST } \\
\text { NIST } \\
\text { NIST } \\
\text { NRCC } \\
\text { USGS } \\
\text { BCR }\end{array}$ & $\begin{array}{l}\text { A } \\
\text { B } \\
\text { C } \\
\text { D } \\
\text { D } \\
\text { E }\end{array}$ & $\begin{array}{l}\text { Coal } \\
\text { Coal } \\
\text { Coal } \\
\text { Marine sediment } \\
\text { Shale } \\
\text { Coal }\end{array}$ & $\begin{array}{c}0.077 \pm 0.017 \\
.12 \pm 0.02 \\
.13 \pm 0.03 \\
.171 \\
.19 \\
.138 \pm 0.011\end{array}$ & $\begin{array}{l}0.068 \\
.091 \\
.119 \\
.175 \\
.182 \\
.143\end{array}$ & $\begin{array}{r}0.005 \\
.011 \\
.007 \\
.02 \\
.011 \\
.005\end{array}$ & $\begin{array}{l}7.4 \\
12 \\
5.9 \\
11 \\
6 \\
3.5\end{array}$ & $\begin{array}{r}88 \\
76 \\
91 \\
102 \\
96 \\
104\end{array}$ \\
\hline
\end{tabular}

Table 4. Comparison of recommended values of selenium concentrations in standard reference materials with mean concentrations determined in this study by hydride-generation atomic absorption spectrometry (HGAAS).

[Column headings: RV, recommended value of selenium concentration from the references A-C; SDEV, standard deviation; \%RSD, relative standard deviation, in percent; \%R, percent recovery, which compares the values obtained by HGAAS in this study with the recommended values; $\mu \mathrm{g} / \mathrm{g}$, micrograms per gram. Sources: NIST, U.S. National Institute of Standards and Technology, formerly the National Bureau of Standards (NBS); USGS, U.S. Geological Survey. References: A, NBS, 1978b; B, Stephen A. Wilson, USGS, oral commun., 1994; C, Eric P. Welsch, USGS, written commun., 1991]

\begin{tabular}{|c|c|c|c|c|c|c|c|c|}
\hline \multirow[b]{2}{*}{ Standard } & \multirow[b]{2}{*}{ Source } & \multirow[b]{2}{*}{ Reference } & \multirow[b]{2}{*}{ Description } & \multirow{2}{*}{$\begin{array}{c}\text { RV } \\
(\mu g / g)\end{array}$} & \multicolumn{3}{|c|}{ This study, HGAAS } & \multirow[b]{2}{*}{$\% R$} \\
\hline & & & & & $\begin{array}{l}\text { Mean } \\
(\mu \mathrm{g} / \mathrm{g})\end{array}$ & $\begin{array}{l}\text { SDEV } \\
(\mu g / g)\end{array}$ & $\%$ RSD & \\
\hline $\begin{array}{l}\text { SRM } 1635 \\
\text { CLB-1 } \\
\text { ALF }\end{array}$ & $\begin{array}{l}\text { NIST } \\
\text { USGS } \\
\text { USGS }\end{array}$ & $\begin{array}{l}\text { A } \\
\text { B } \\
\text { C }\end{array}$ & $\begin{array}{l}\text { Coal } \\
\text { Coal } \\
\text { Alfalfa }\end{array}$ & $\begin{array}{l}0.9 \\
2.1 \\
.19\end{array}$ & $\begin{array}{l}0.95 \\
2.5 \\
.18\end{array}$ & $\begin{array}{l}0.10 \\
.2 \\
.02\end{array}$ & $\begin{array}{r}11 \\
8 \\
11\end{array}$ & $\begin{array}{r}108 \\
119 \\
95\end{array}$ \\
\hline
\end{tabular}

quality control, several standard reference materials were also analyzed for mercury and selenium by CVAAS and HGAAS, and the results are reported in tables 3 and 4, respectively. The standards chosen were coal, shale, a plant, and marine sediment. The tables compare the published values of the reference materials with the mean and standard deviation obtained from these methods.

The lower limits of determination for mercury and selenium are 0.01 and $0.1 \mu \mathrm{g} / \mathrm{g}$, respectively, which are based on three times the standard deviation of the blank. The precision of the mercury values is in the range of 3.5 to 12 percent relative standard deviation (\%RSD), and the accuracy, based on the percent recovery (\%R), which compares this method's values with the recommended values (RV), ranges from 76 to 104 percent (table 3). The precision of the values for selenium is in the range of 8 to $11 \% \mathrm{RSD}$, and the accuracy or \%R ranges from 95 to 119 percent of the recommended values (table 4). Both methods offer a technique that is simple and rapid, and both are applicable to a wide range of organically based samples.

\section{REFERENCES}

Aruscavage, Philip, 1977, Determination of arsenic, antimony, and selenium in coal by atomic absorption spectrometry with a graphite tube atomizer: U.S. Geological Survey Journal of Research, v. 5, no. 4, p. 405-408.

Govindaraju, K., ed., 1989, 1989 Compilation of working values and sample description of 272 geostandards: Geostandards Newsletter, v. 13, Special Issue, p. 67.

Griepink, B., Colinet, E., and Wilkinson, H.C., 1986, The certification of the contents (mass fraction) of carbon, hydrogen, nitrogen, chlorine, arsenic, cadmium, manganese, mercury, lead, selenium, vanadium and zinc in three coals; gas coal CRM No. 180 , coking coal CRM No. 181 , and steam coal CRM No. 182: Commission of the European Communities, 
Community Bureau of Reference (Brussels), Report EUR 10366 EN, 170 p.

Kennedy, K.R., and Crock, J.G., 1987, Determination of mercury in geological materials by continuous-flow, cold-vapor, atomic absorption spectrophotometry: Analytical Letters, v. 20, p. 899-908.

Lengyel, J., Jr., DeVito, M.S., and Bilonick, R.A., 1994, Interlaboratory and intralaboratory variability in the analysis of mercury in coal: Library, Pa., Consol Inc.

National Bureau of Standards, 1974, National Bureau of Standards certificate of analysis, standard reference material 1632, trace elements in coal (bituminous): Washington, D.C., National Bureau of Standards, 2 p.

1978a, National Bureau of Standards certificate of analysis, standard reference material 1632a, trace elements in coal (bituminous): Washington, D.C., National Bureau of Standards, 2 p.

1978b, National Bureau of Standands certificate of analysis, standard reference material 1635, trace elements in coal (subbituminous): Washington, D.C., National Bureau of Standards, 2 p. 


\title{
Determination of Carbon, Hydrogen, and Nitrogen in Eight Argonne Premium Coal Samples by Using a Gas Chromatographic Analyzer with a Thermal Conductivity Detector
}

\author{
By Carol J. Skeen and Zoe A. Brown
}

\begin{abstract}
The carbon, hydrogen, and nitrogen contents of eight Argonne Premium Coals were determined by using the Perkin-Elmer 240B elemental gas chromatographic (GC) analyzer with a thermal conductivity detector (TCD). Precision for the analysis of these samples is within the accepted 0.1 percent relative standard deviation. The carbon content ranged from 56 to 86 percent; the hydrogen content ranged from 3.7 to 5.6 percent; and the nitrogen content ranged from 0.93 to 2.2 percent. Because these ranges are typical for coals, the NIST (National Institute of Standards and Technology) 1635 coal standard reference material was chosen as the control standard to evaluate the accuracy of the method.
\end{abstract}

\section{INTRODUCTION}

Analysis of a substance for carbon, hydrogen, and nitrogen generally requires drastic treatment of the material in order to convert the elements into a form readily determined by routine analytical techniques. A common way to convert the carbon, hydrogen, and nitrogen to gaseous products is to carry out an oxidation in a quartz combustion tube through which is forced a stream of carrier gas. The stream transports the volatile products to the part of the apparatus where they can be separated for measurement.

The combustion train is packed with silver compounds to remove any halogen and sulfur compounds generated, because these compounds interfere with the determination of carbon dioxide and water. Before reaching the combustion train, the helium and oxygen flow through scrubbers packed with colorcarb and anhydron to remove extraneous contaminants.

The Perkin-Elmer 240B elemental gas chromatographic analyzer with a thermal conductivity detector gives excellent results for finely ground, dry materials, especially
Tabie 1. Comparison of published concentrations of carbon, hydrogen, and nitrogen in NIST standard reference material 1635 (coal) with concentrations determined in this study by using a gas chromatographic analyzer with a thermal conductivity detector (GC/TCD).

[All concentrations are in weight percent. NIST, National Institute of Standards and Technology, formerly the National Bureau of Standards (NBS)]

\begin{tabular}{|c|c|c|c|}
\hline Element & $\begin{array}{l}\text { This study, } \\
\text { GC/TCD }\end{array}$ & NBS (1978) & $\begin{array}{l}\text { Gladney and } \\
\text { others (1987) }\end{array}$ \\
\hline $\begin{array}{l}\mathrm{C} \\
\mathrm{H} \\
\mathrm{N}\end{array}$ & $\begin{array}{l}63.0 \\
3.98 \\
1.5\end{array}$ & $\begin{array}{c}62.2 \pm 1.8 \\
3.96 \pm 0.03 \\
1.0 \pm 0.1\end{array}$ & $\begin{array}{l}62.6 \\
4.07 \\
1.26\end{array}$ \\
\hline
\end{tabular}

materials high in organic matter, with the following concentration ranges: $0.1-100$ percent for carbon, $0.01-12$ percent for hydrogen, and 0.10-18 percent for nitrogen.

\section{ANALYTICAL PROCEDURE}

Standard operating procedures for use of the PerkinElmer 240B and a revised statistical computer program (Abramowitz, 1964) were implemented for the analysis of the eight Argonne Premium Coals. Oxygen was the combustion gas, and helium was the carrier gas. The instrument was calibrated by oxidizing three samplings of standard acetanilide, all of approximately the same weight (1.0 to 1.3 $\mathrm{mg}$ ). The furnace temperatures were $950^{\circ} \mathrm{C}$ for the combustion tube and $650^{\circ} \mathrm{C}$ for the reduction tube. The sample weights used were between $1.0 \mathrm{mg}$ and $1.3 \mathrm{mg}$.

The NIST (National Institute of Standards and Technology, formerly the National Bureau of Standards) 1635 coal standard reference material (SRM) was analyzed as a control standard at the same time as the last three premium coals. Table 1 shows these results along with the NIST SRM 
Table 2. Comparison of published concentrations of carbon, hydrogen, and nitrogen in eight Argonne Premium Coals with concentrations determined in this study by using a gas chromatographic analyzer with a thermal conductivity detector (GC/TCD).

[All concentrations are in weight percent]

\begin{tabular}{|c|c|c|c|c|c|c|}
\hline \multirow{2}{*}{ Coal samples } & \multicolumn{2}{|c|}{ C } & \multicolumn{2}{|c|}{$\mathbf{H}$} & \multicolumn{2}{|c|}{$\mathbf{N}$} \\
\hline & This study & Vorres (1990) & This study & Vorres (1990) & This study & Vorres (1990) \\
\hline $\begin{array}{l}\text { UF PC-1-1 ...... } \\
\text { UF PC-1-2 ...... } \\
\text { UF PC- } 1-3 \ldots \ldots .\end{array}$ & $\begin{array}{l}77 \\
76 \\
-\end{array}$ & & $\begin{array}{l}4.6 \\
4.7 \\
-\end{array}$ & & $\begin{array}{l}2.2 \\
1.8 \\
\end{array}$ & \\
\hline UF Average ...... & 77 & 74.23 & 4.7 & 4.08 & 2.0 & 1.35 \\
\hline $\begin{array}{l}\text { WY PC-2-1...... } \\
\text { WY PC-2-2 ..... } \\
\text { WY PC-2-3... }\end{array}$ & $\begin{array}{l}60 \\
60 \\
\end{array}$ & & $\begin{array}{l}4.4 \\
4.6 \\
-\end{array}$ & & $\begin{array}{l}1.2 \\
1.2 \\
-\end{array}$ & \\
\hline $\begin{array}{l}\text { WY Average.... } \\
\text { WY Repeat...... }\end{array}$ & $\begin{array}{l}60 \\
61\end{array}$ & 68.43 & 4.5 & 4.88 & 1.2 & 1.02 \\
\hline $\begin{array}{l}\text { IL PC-3-1 ........ } \\
\text { IL PC-3-2 ........ } \\
\text { IL PC-3-3 ......... }\end{array}$ & $\begin{array}{l}64 \\
65 \\
\end{array}$ & & $\begin{array}{l}4.5 \\
4.5 \\
-\end{array}$ & & $\begin{array}{l}1.6 \\
1.8 \\
\end{array}$ & \\
\hline IL Average ......... & 65 & 65.65 & 4.5 & 4.23 & 1.7 & 1.16 \\
\hline 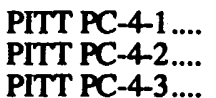 & $\begin{array}{l}74 \\
75 \\
\end{array}$ & & $\begin{array}{l}5.0 \\
5.0 \\
\end{array}$ & & $\begin{array}{l}2.2 \\
2.0 \\
-\end{array}$ & \\
\hline PITT Average.. & 75 & 75.50 & 5.0 & 4.83 & 2.1 & 1.49 \\
\hline $\begin{array}{l}\text { POC PC-5-1 .... } \\
\text { POC PC-5-2 } \ldots \\
\text { POC PC-5-3 .... }\end{array}$ & $\begin{array}{l}86 \\
86 \\
-\end{array}$ & & $\begin{array}{l}4.4 \\
4.3 \\
-\end{array}$ & & $\begin{array}{l}1.9 \\
2.0 \\
\end{array}$ & \\
\hline POC Average... & 86 & 86.71 & 4.4 & 4.23 & 2.0 & 1.27 \\
\hline $\begin{array}{l}\text { UT PC-6-1 ....... } \\
\text { UT PC-6-2....... } \\
\text { UT PC-6-3...... } \\
\text { UT Average ..... }\end{array}$ & $\begin{array}{l}72 \\
74 \\
74 \\
73\end{array}$ & 76.89 & $\begin{array}{l}5.5 \\
5.5 \\
5.6 \\
5.5\end{array}$ & 5.49 & $\begin{array}{l}1.6 \\
1.8 \\
1.4 \\
1.6\end{array}$ & 1.50 \\
\hline $\begin{array}{l}\text { WV PC-7-1...... } \\
\text { WV PC-7-2..... } \\
\text { WV PC-7-3..... } \\
\text { WV Average.... }\end{array}$ & $\begin{array}{l}64 \\
65 \\
66 \\
65\end{array}$ & 66.20 & $\begin{array}{l}4.3 \\
4.3 \\
4.2 \\
4.3\end{array}$ & 4.21 & $\begin{array}{l}1.3 \\
1.4 \\
1.4 \\
1.4\end{array}$ & 1.25 \\
\hline $\begin{array}{l}\text { ND PC-8-1 ...... } \\
\text { ND PC-8-2 ...... } \\
\text { ND PC-8-3 ...... } \\
\text { ND Average..... } \\
\text { ND Repeat....... }\end{array}$ & $\begin{array}{l}56 \\
57 \\
57 \\
57 \\
57\end{array}$ & 65.85 & $\begin{array}{l}3.8 \\
3.7 \\
3.7 \\
3.7\end{array}$ & 4.36 & $\begin{array}{l}1.2 \\
1.0 \\
.93 \\
1.0\end{array}$ & 1.04 \\
\hline
\end{tabular}

values (National Bureau of Standards, 1978) and the analytical values of Gladney and others (1987).

\section{RESULTS AND DISCUSSION}

A study was made to ascertain the detection limits of this method (Filby and others, 1985). By diluting pure acetanilide with ultra-pure silica to prepare three analytical standards- (1) 7.1 percent $C, 0.67$ percent $H$, and 1.04 percent $\mathrm{N}$, (2) 0.71 percent $C, 0.067$ percent $H$, and 0.104 percent $N$, and (3) 0.071 percent $C, 0.0067$ percent $H$, and 0.010 percent $\mathrm{N}$-and by using acetanilide undiluted $(71.07$ per- cent $C, 6.71$ percent $H$, and 10.36 percent $N$ ), the lowest detection limits were calculated to be 0.1 percent $C, 0.01$ percent $\mathrm{H}$, and 0.10 percent $\mathrm{N}$. The experiment using various sampling weights also validated that the analytical curves were linear from the detection limit to the highest standard.

The results of these coal analyses were compared with the published data for the Argonne Premium Coal Sample Program (Vorres, 1990) for carbon, hydrogen, and nitrogen determined on dried whole coals. The values were in good agreement with all the coals except for the carbon values for the subbituminous coal (WY) and the lignite (ND). To verify the accuracy of this paper's results, analyses of these two 
samples were repeated with special attention given to proper drying of the samples before analysis. The carbon values obtained by the repeat analyses, 61 percent for WY and 57 percent for ND, are in agreement with values obtained by the initial analyses. Table 2 shows the results for the replicate analyses of these coals, the repeats, and Vorres' published data.

The differences between the results from Argonne National Laboratories (Vorres, 1990) and the data reported in this paper could be due to oxidation of these two coals. Argonne went to great lengths to seal these coals in an oxygen-free environment. Because analysis in the U.S. Geological Survey laboratories was not done immediately after the ampoules were opened, it is likely that the subbituminous coal and the lignite oxidized. Bituminous coals are characteristically more stable.

The precision of this method is within the 0.1 percent relative standard deviation, which is well within the accepted deviation for this type of analysis. The analysis of NIST 1635 indicates that the accuracy is also excellent.

\section{REFERENCES}

Abramowitz, M., 1964, Elementary analytical methods, in Abramowitz, M., and Stegun, I.A., eds., Handbook of mathematical functions-National Bureau of Standards Applied Mathematics Series 55: Washington, D.C., U.S. Government Printing Office, chap. 3, p. 18.

Filby, R.H., and others, 1985, Evaluation of geochemical standard reference materials for microanalysis: Analytical Chemistry, v. 57, no. 2, p. 551-555.

Gladney, E.S., O'Malley, B.T., Roelundts, J., and Gilly, T.E., 1987, Composition of elemental concentration data for NIST clinical, biological, geological and environmental standand reference materials: National Institute of Standards and Technology Special Publication 260-111, p. 21-22.

National Bureau of Standards, 1978, National Bureau of Standards certificate of analysis, standand reference material 1635 , trace elements in coal (subbituminous): Washington, D.C., National Bureau of Standards, 2 p.

Vorres, K.S., 1990, The Argonne Premium Coal Sample Program: Energy and Fuels, v. 4, no. 5, p. 420-426. 


\title{
Compilation of Multitechnique Determinations of 51 Elements in 8 Argonne Premium Coal Samples
}

\author{
By Curtis A. Palmer and Sarah A. Klizas
}

\begin{abstract}
Eight Argonne Premium Coal samples were analyzed by the U.S. Geological Survey. The concentrations of 51 elements were determined by two or more techniques on each sample. The analyses were performed by energy- and wavelength-dispersive X-ray fluorescence spectrometry, instrumental neutron activation analysis, inductively coupled argon plasma-atomic emission spectroscopy, atomic absorption spectrometry, inductively coupled argon plasmamass spectrometry, and direct-current arc spectrographic analysis. All data are compiled on a whole-coal basis for ease of comparison. The ash values are also included so that data can be converted to an ash basis if desired.
\end{abstract}

\section{INTRODUCTION}

Although the eight Argonne Premium Coal samples analyzed in this study are not defined as "reference standards" by Argonne National Laboratories, they are extremely important because of the care that has been taken in collection, preparation, and storage. A detailed description of the background information for these samples has been reported by Vorres $(1990,1993)$. However, these samples have not been widely analyzed for trace elements. The analytical laboratories of the U.S. Geological Survey analyzed these samples to further characterize them and to provide a foundation for a trace-element data base.

Most quantitative techniques used for elemental analyses of geologic samples offer high levels of precision and accuracy for selected elements in certain types of samples over specific ranges of concentrations, but all analytical techniques have certain characteristic limitations. For example, matrix-induced spectral interferences can result in incorrect determinations of trace elements. Even if properly corrected, these interferences may lead to reduced sensitivity or precision for a given element. Generally, the concentrations of elements determined by another technique on the same matrix will not be affected by the same interferences.
A multitechnique approach for major- and trace-element analysis was taken to provide the high degree of reliability desired to characterize these materials. In addition, this information may be useful in evaluating data from a single technique for coal analysis for laboratories that do not have all techniques available. Semiquantitative analytical techniques, although not offering the precision or accuracy of the quantitative techniques, rapidly provide a large volume of data. Some of the data obtained by these low-precision techniques are not easily obtained by quantitative methods, but can be useful in the overall characterization of these materials.

This paper (1) summarizes the results of the multitechnique analyses of the Argonne Premium Coals, (2) discusses some discrepancies in the data, and (3) determines "recommended values" or "best averages" depending on the precision of the data. Each of the eight Premium Coal samples has been analyzed in triplicate for 68 elements. Fiftyone elements were determined by more than one technique. Although up to seven different techniques were used for some elements, there are not enough high-precision data to recommend values for all elements in all coals using common criteria for establishing such values (Kane and others, 1990). Therefore, modified criteria were designed for this data set. They allowed definition of "recommended values" on slightly less than half of the elements included in the data set.

\section{SAMPLES AND TECHNIQUES}

Three splits of each of the Argonne Premium Coal samples were analyzed by multiple techniques. The samples and the sample identification protocol are described in this volume by Palmer (see p. 1).

Ideally, solid samples of the whole coal would be analyzed by instrumental techniques because this type of analysis avoids problems caused by volatilization of elements during ashing and problems caused by incomplete sample dissolution. The procedures used for determining element 
concentrations instrumentally on the whole coal are discussed in this volume in the following papers:

\section{Author Procedure}

Fletcher and Skeen.. Quantitative DCAES, direct-current arc atomic emission spectrography

Evans and others ..... WDXRF, wavelength-dispersive $\mathrm{X}$ ray fluorescence spectrometry

EDXRF, energy-dispersive XRF

Palmer

INAA, instrumental neutron activation analysis

O'Leary ................... CVAAS and HGAAS, cold-vapor and hydride-generation atomic absorption spectrometry

Skeen and Brown .... Gas chromatographic analysis with a thermal conductivity detector

Although the sensitivity of INAA was acceptable for most of the 29 elements determined, the sensitivities of the other whole-coal procedures were marginal for many elements. Therefore, coal ash procedures were also used for WDXRF, EDXRF, and DCAES (see list below) to concentrate the trace elements and thereby increase sensitivities.

Techniques that require analysis of coal ash were used as described in the following papers in this volume:

\section{Author}

\section{Procedure}

Skeen and others ..... $\begin{aligned} & \text { Semiquantitative DCAES } \\ & \text { Evans and others ..... } \\ & \text { WDXRF } \\ & \text { EDXRF } \\ & \text { Doughten ................ ICAP-AES, inductively coupled } \\ & \text { argon plasma-atomic emission } \\ & \text { spectrometry } \\ & \text { FAAS, flame atomic absorption spec- } \\ & \text { trometry } \\ & \text { GFAAS, graphite furnace atomic } \\ & \text { absorption spectrometry }\end{aligned}$
Briggs ..................... ICAP-AES
ICAer.................... ICAP-MS, inductively coupled argon
plasma-mass spectrometry

All samples were ashed at $525^{\circ} \mathrm{C}$ to limit volatilization of lead, cadmium, and other moderately volatile trace elements. Ash yields were determined on the same splits used for the analyses and were used to calculate data as if determined on a whole-coal basis. The $525^{\circ} \mathrm{C}$ ash yields, which are not directly comparable to those determined by ASTM (American Society for Testing and Materials, 1996) ash procedures $\left(750^{\circ} \mathrm{C}\right)$ but are generally similar, can be used to recalculate back to an ash basis if desired.

\section{DISCUSSION OF RESULTS}

Direct comparison of results presented in previous papers in this volume is difficult because data are presented in three different forms depending on the analytical technique used and the material analyzed. Concentrations are reported on an ash basis for some procedures, on a wholecoal basis for some procedures, and on an oxide basis of the ash for major elements determined by WDXRF and DCAES. To facilitate a direct comparison of the data, the ash data have been recalculated to whole-coal values and converted to an element basis for those elements reported on an oxide basis. The entire recalculated data set for all splits can be found in appendix 1 . The number of significant figures given in the original papers has been maintained in the converted values.

A careful examination of appendix 1 shows that analytical procedures can be classified into two categories: highly precise (HP) procedures shown in bold, which generally have a relative standard deviation of less than 5 percent, and procedures that are less precise (LP). The precision was calculated by determining the percent of difference between the three individual data points and their mean for each sample-element pair. Using the accuracy guidelines discussed later in this paper, each test for each element was given a rating of good, usable, or poor precision. Comparisons of the different ratings for all elements determined by each technique were made. Finally, the techniques were divided into the two precision groups (LP and HP) based on which rating they received most frequently. In this study, the two DCAES procedures (ash and whole coal) and the X-ray whole-coal procedures were classified as LP procedures; INAA, ICAP-AES, ICAP-MS, CVAAS, HGAAS, FAAS, GFAAS, and the other $\mathrm{X}$-ray procedures were classified as HP procedures. It should be noted that no procedures had the same precision for all elements in all samples. For the designated HP techniques, most determinations were of high precision, but as expected, determinations near the detection limit for some samples had poorer precision. LP procedures generally had lower precision for all samples and elements.

Statistical approaches are useful for large data sets; however, often they do not provide the detail that is useful in evaluating individual problems in the data. Even though the individual samples were analyzed only in triplicate, the complete data set requires 18 pages (appendix 1). A summary of the data is given in tables 1 and 2. Table 1 presents the method averages of the major rock-forming-element data determined on each of the three splits of the eight Argonne Premium Coal samples. Table 2 is a similar table for the trace-element data.

Statistical analysis of the data in appendix 1 is given in appendix 2 . These data include the number of samples for which values were determined, the arithmetic mean (mean), the standard deviation, the relative standard deviation, the 
Table 1. Average concentrations of major elements in weight percent based on triplicate analyses.

[Values in brackets are averages of two analyses, and numbers in parentheses are based on only one analysis. Data from high-precision techniques are in bold except outliers. An * indicates that the analysis was done in Denver. Complete data set is given in appendix 1 . Material analyzed: $(A)=$ ash, $(C)=$ whole coal. -, no data]

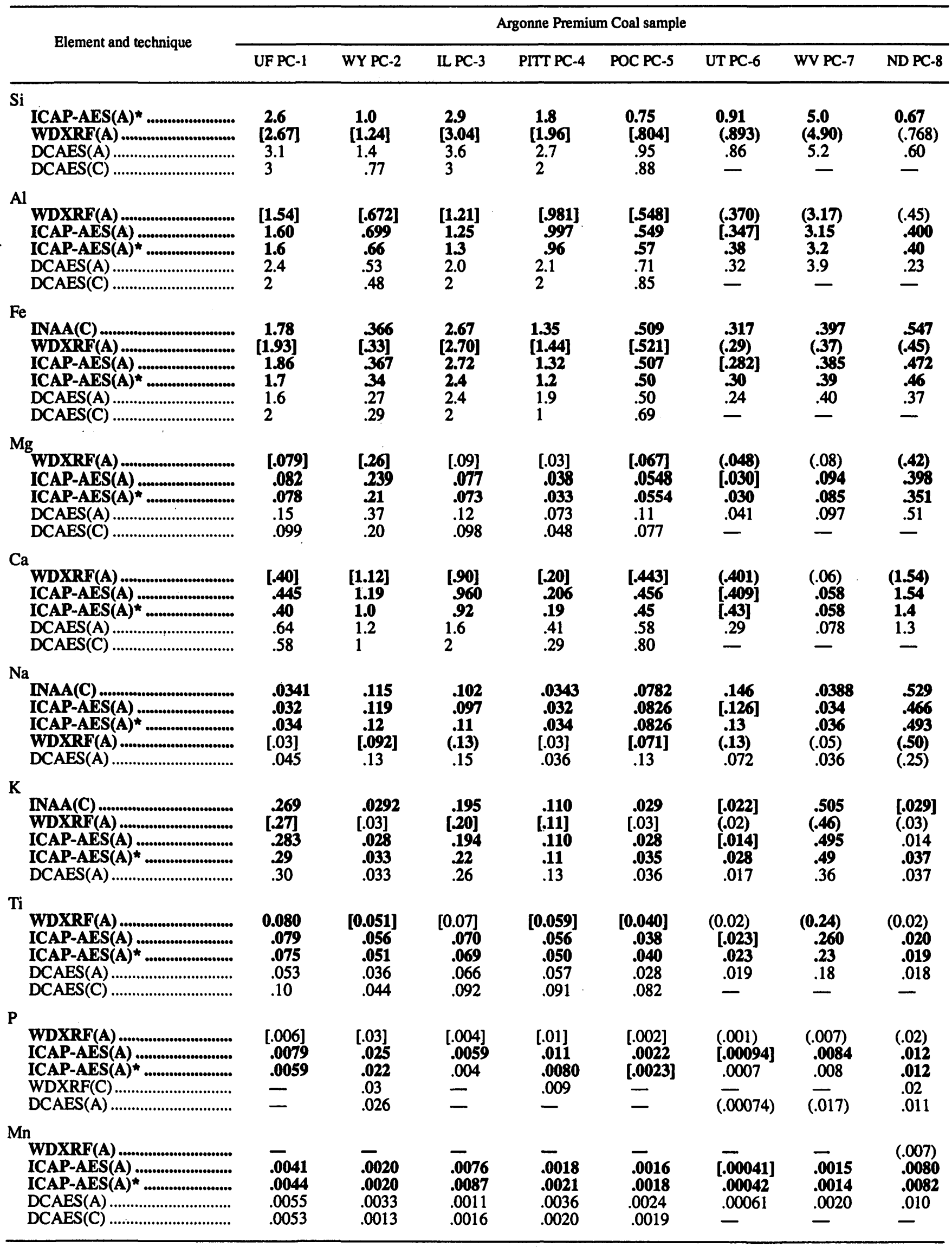


Table 2. Average concentrations of trace elements in parts per million based on triplicate analyses.

[Bracketed values are averages of two analyses, and numbers in parentheses are based on only one analysis. Data from high-precision techniques are in bold except outliers. An * indicates that the analysis was done in Denver. Complete data set is given in appendix 1 . Material analyzed: $(A)=$ ash, $(C)=$ whole coal. - no data]

\begin{tabular}{|c|c|c|c|c|c|c|c|c|}
\hline \multirow{2}{*}{ Element and technique } & \multicolumn{8}{|c|}{ Argonne Premium Coal sample } \\
\hline & UF PC-1 & WY PC-2 & IL PC-3 & PITT PC-4 & POC PC-5 & UT PC-6 & WV PC-7 & ND PC-8 \\
\hline 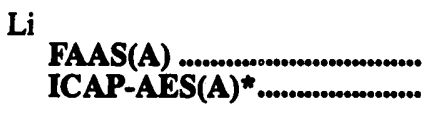 & $\begin{array}{l}15 \\
15\end{array}$ & $\begin{array}{l}4.1 \\
3.9\end{array}$ & $\begin{array}{l}7.8 \\
7.7\end{array}$ & $\begin{array}{l}8.6 \\
8.9\end{array}$ & $\begin{array}{l}5.8 \\
5.5\end{array}$ & $\begin{array}{l}5.1 \\
5.5\end{array}$ & $\begin{array}{l}29 \\
27\end{array}$ & $\begin{array}{l}2.7 \\
2.7\end{array}$ \\
\hline 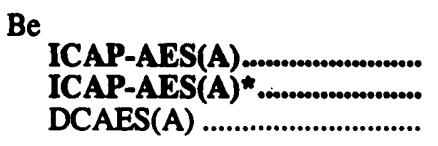 & $\begin{array}{l}1.5 \\
1.5 \\
1.4\end{array}$ & $\begin{array}{l}.25 \\
.3 \\
.14\end{array}$ & $\begin{array}{l}.76 \\
.6 \\
.97\end{array}$ & $\begin{array}{l}.77 \\
.7 \\
1.2\end{array}$ & $\begin{array}{l}.80 \\
.80 \\
.67\end{array}$ & $\begin{array}{l}{[.13]} \\
.1 \\
.20\end{array}$ & $\begin{array}{l}1.9 \\
2.1 \\
3.0\end{array}$ & $\begin{array}{l}{[.18]} \\
.2 \\
.28\end{array}$ \\
\hline 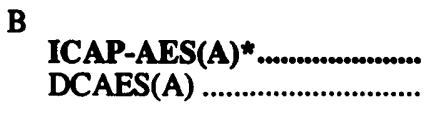 & $\begin{array}{l}38 \\
30\end{array}$ & $\begin{array}{l}96 \\
70\end{array}$ & $\begin{array}{l}160 \\
120\end{array}$ & $\begin{array}{l}48 \\
51\end{array}$ & $\begin{array}{l}13 \\
17\end{array}$ & ${ }^{130}-$ & $\begin{array}{l}56 \\
57\end{array}$ & $\begin{array}{l}79 \\
67\end{array}$ \\
\hline 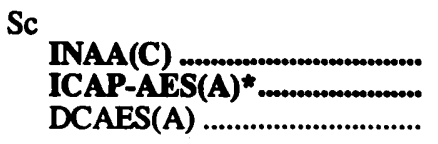 & $\begin{array}{l}4.06 \\
3.9 \\
2.1\end{array}$ & $\begin{array}{l}1.68 \\
1.6 \\
1.3\end{array}$ & $\begin{array}{l}2.59 \\
2.7 \\
2.6\end{array}$ & $\begin{array}{r}2.57 \\
2.5 \\
1.9\end{array}$ & $\begin{array}{l}1.79 \\
1.8 \\
1.3\end{array}$ & $\begin{array}{l}.813 \\
.75 \\
.69\end{array}$ & $\begin{array}{l}7.62 \\
7.4 \\
6.4\end{array}$ & $\begin{array}{l}.846 \\
.8 \\
.90\end{array}$ \\
\hline 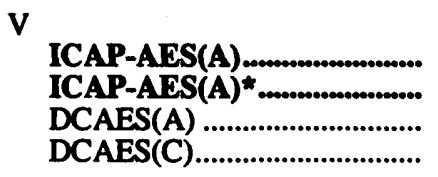 & $\begin{array}{l}26 \\
27 \\
16 \\
41\end{array}$ & $\begin{array}{l}14 \\
14 \\
9.0 \\
14\end{array}$ & $\begin{array}{l}32 \\
37 \\
24 \\
52\end{array}$ & $\begin{array}{l}15 \\
17 \\
13 \\
24\end{array}$ & $\begin{array}{c}11 \\
12 \\
7.1 \\
18\end{array}$ & $\begin{array}{c}{[4.0]} \\
4.5 \\
3.7 \\
-\end{array}$ & $\begin{array}{l}44 \\
43 \\
32 \\
-\end{array}$ & $\begin{array}{l}3.5 \\
3.9 \\
3.6 \\
-\end{array}$ \\
\hline 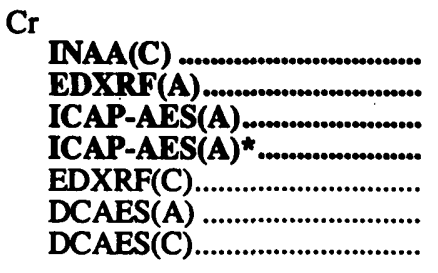 & $\begin{array}{l}20.3 \\
26.0 \\
20 \\
22 \\
19 \\
19 \\
32\end{array}$ & $\begin{array}{c}6.1 \\
{[8.2]} \\
6.2 \\
6.4 \\
{[4]} \\
5.7 \\
7\end{array}$ & $\begin{array}{l}33.1 \\
43.2 \\
31 \\
36 \\
35 \\
38 \\
52\end{array}$ & $\begin{array}{l}14.8 \\
17.9 \\
14 \\
16 \\
8 \\
19 \\
24\end{array}$ & $\begin{array}{c}9.1 \\
12.3 \\
9.2 \\
9.7 \\
5 \\
8.8 \\
16\end{array}$ & $\begin{array}{l}5.30 \\
\overline{4.8]} \\
5.2 \\
\frac{4.8}{-}\end{array}$ & $\begin{array}{l}35.8 \\
45.9 \\
40 \\
39 \\
49 \\
39 \\
-\end{array}$ & $\begin{array}{l}2.24 \\
2.6 \\
2.4 \\
2.3 \\
-4 \\
-\end{array}$ \\
\hline 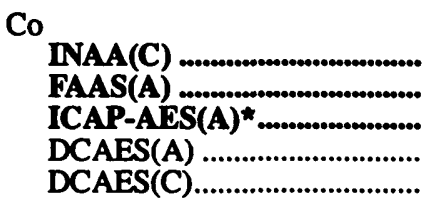 & $\begin{array}{l}\mathbf{5 . 3 3} \\
\mathbf{5 . 0} \\
\mathbf{5 . 3} \\
3.5 \\
5\end{array}$ & $\begin{array}{l}1.68 \\
1.6 \\
1.7 \\
1.3 \\
-\end{array}$ & $\begin{array}{l}4.31 \\
4.3 \\
4.4 \\
3.7 \\
-\end{array}$ & $\begin{array}{l}2.62 \\
2.4 \\
2.6 \\
2.6 \\
-\end{array}$ & $\begin{array}{l}4.07 \\
3.8 \\
4.0 \\
2.6 \\
5\end{array}$ & $\begin{array}{l}1.00 \\
{[.83]} \\
.94 \\
.64 \\
-\end{array}$ & $\begin{array}{l}7.74 \\
8.1 \\
7.5 \\
6.3 \\
-\end{array}$ & $\begin{array}{l}.778 \\
-9 \\
.55 \\
-\end{array}$ \\
\hline 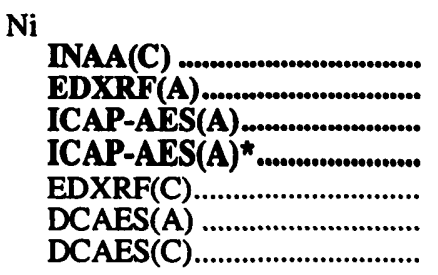 & $\begin{array}{l}14.5 \\
14 \\
14 \\
17 \\
23 \\
14 \\
25\end{array}$ & $\begin{array}{l}4.9 \\
3.9 \\
4.9 \\
4.8 \\
8 \\
5.2 \\
-\end{array}$ & $\begin{array}{l}21.0 \\
18 \\
18 \\
{[19]} \\
32 \\
22 \\
33\end{array}$ & $\begin{array}{c}{[10.3]} \\
9.3 \\
8.5 \\
9.1 \\
14 \\
13 \\
12\end{array}$ & $\begin{array}{c}8.6 \\
7.58 \\
6.7 \\
7.4 \\
11 \\
6.5 \\
{[11]}\end{array}$ & $\begin{array}{l}{[3.4]} \\
{[3.3]} \\
3.5 \\
5 \\
4.0 \\
-\end{array}$ & $\begin{array}{l}15.4 \\
17 \\
16 \\
16 \\
18 \\
21 \\
-\end{array}$ & $\begin{array}{l}\overline{1.9} \\
1.3 \\
1.4 \\
6 \\
1.8 \\
-\end{array}$ \\
\hline 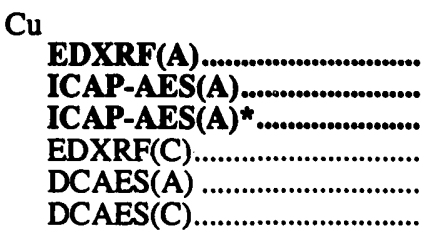 & $\begin{array}{l}20.4 \\
19 \\
19 \\
18 \\
17 \\
18\end{array}$ & $\begin{array}{l}129 \\
12 \\
14 \\
17 \\
13 \\
7\end{array}$ & $\begin{array}{l}9.6 \\
10 \\
11 \\
14 \\
11 \\
9\end{array}$ & $\begin{array}{c}6.2 \\
5.5 \\
5.8 \\
10 \\
6.5 \\
6\end{array}$ & $\begin{array}{l}\mathbf{1 2 . 5} \\
12 \\
16 \\
17 \\
19 \\
19\end{array}$ & $\begin{array}{c}-\overline{3.8]} \\
4.2 \\
8 \\
2.9 \\
-\end{array}$ & $\begin{array}{l}\mathbf{2 3 . 6} \\
\mathbf{1 9} \\
\mathbf{2 1} \\
31 \\
16 \\
-\end{array}$ & $\begin{array}{c}3.3 \\
4.7 \\
{[4.6]} \\
9 \\
4.9 \\
-\end{array}$ \\
\hline 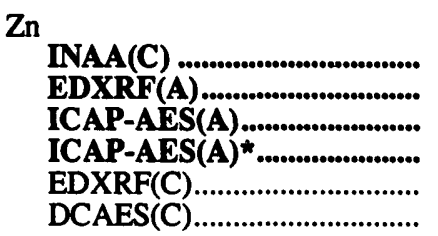 & $\begin{array}{l}19.7 \\
20.5 \\
19 \\
19 \\
33 \\
33\end{array}$ & $\begin{array}{l}11.3 \\
10.6 \\
10 \\
12 \\
25 \\
-\end{array}$ & $\begin{array}{l}220 \\
107 \\
180 \\
190 \\
140 \\
280\end{array}$ & $\begin{array}{l}9.1 \\
8.4 \\
7.8 \\
{[8.1]} \\
15 \\
27\end{array}$ & $\begin{array}{c}6.4 \\
4.8 \\
4.0 \\
5.3 \\
14 \\
-\end{array}$ & $\begin{array}{c}6.35 \\
\overline{-} \\
{[6.2]} \\
4.8 \\
- \\
-\end{array}$ & $\begin{array}{l}13.5 \\
12 \\
13 \\
11 \\
10 \\
-\end{array}$ & $\begin{array}{l}5.69 \\
5.4 \\
4.6 \\
4.8 \\
5 \\
-\end{array}$ \\
\hline
\end{tabular}


Table 2. Average concentrations of trace elements in parts per million based on triplicate analyses-Continued.

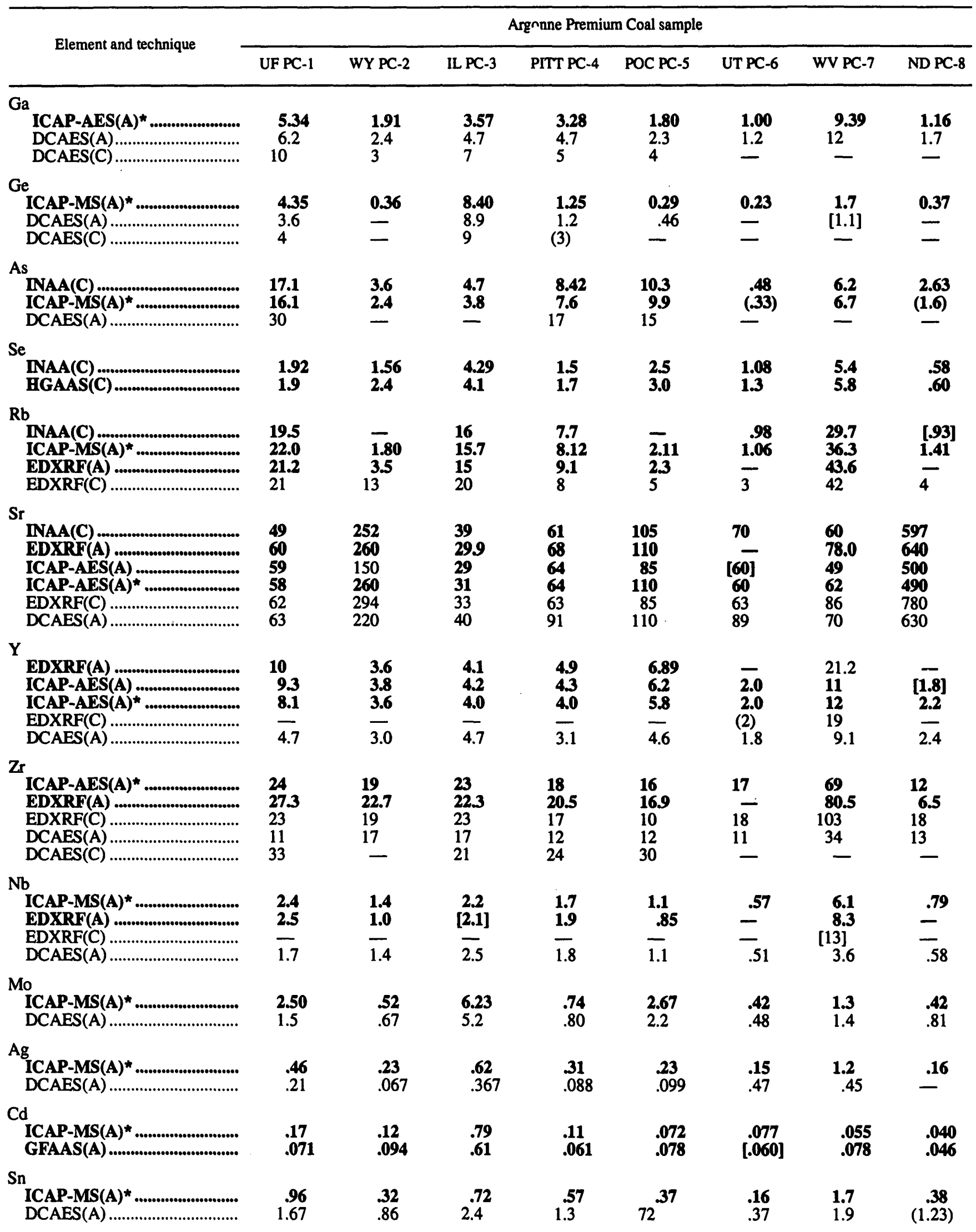


Table 2. Average concentrations of trace elements in parts per million based on triplicate analyses-Continued.

\begin{tabular}{|c|c|c|c|c|c|c|c|c|}
\hline \multirow{2}{*}{ Element and technique } & \multicolumn{8}{|c|}{ Argonne Premium Coal sample } \\
\hline & UF PC-1 & WY PC-2 & IL PC-3 & PITT PC-4 & POC PC-5 & UT PC-6 & WV PC-7 & ND PC-8 \\
\hline 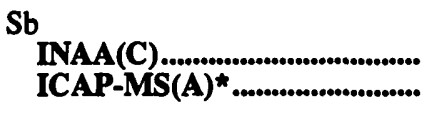 & $\begin{array}{l}.531 \\
.49\end{array}$ & $\begin{array}{l}.191 \\
.16\end{array}$ & $\begin{array}{l}.877 \\
.79\end{array}$ & $\begin{array}{l}.233 \\
.20\end{array}$ & $\begin{array}{l}.539 \\
.27\end{array}$ & $\begin{array}{l}.107 \\
.089\end{array}$ & $\begin{array}{l}.521 \\
.56\end{array}$ & $\begin{array}{l}.153 \\
.16\end{array}$ \\
\hline 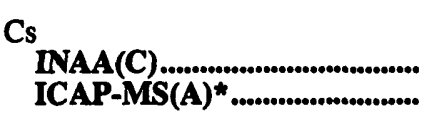 & $\begin{array}{l}1.52 \\
1.89\end{array}$ & $\begin{array}{l}.191 \\
.19\end{array}$ & $\stackrel{.877}{1.4}^{87}$ & $\begin{array}{l}.70 \\
.80\end{array}$ & $\begin{array}{l}.262 \\
.22\end{array}$ & $\begin{array}{l}.130 \\
.14\end{array}$ & $\begin{array}{l}1.86 \\
2.33\end{array}$ & $\begin{array}{l}.086 \\
.10\end{array}$ \\
\hline 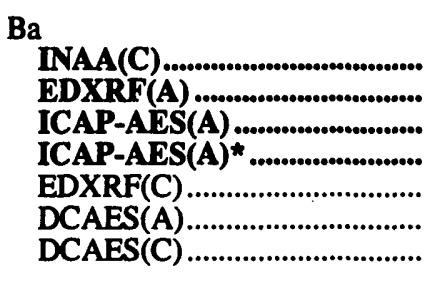 & $\begin{array}{l}\mathbf{6 1} \\
\mathbf{5 2} \\
\mathbf{5 5} \\
\mathbf{5 6} \\
60 \\
41 \\
\mathbf{8 1}\end{array}$ & $\begin{array}{r}310 \\
270 \\
15 \\
290 \\
410 \\
320 \\
250\end{array}$ & $\begin{array}{l}94 \\
74.5 \\
81 \\
82 \\
121 \\
60 \\
120\end{array}$ & $\begin{array}{l}47 \\
35.7 \\
41 \\
39 \\
30 \\
38 \\
66\end{array}$ & $\begin{array}{r}198 \\
180 \\
16 \\
210 \\
140 \\
210 \\
450\end{array}$ & $\begin{array}{l}36 \\
31 \\
35 \\
29 \\
36 \\
-\end{array}$ & $\begin{array}{l}133 \\
110 \\
120 \\
120 \\
210 \\
130 \\
-\end{array}$ & $\begin{array}{r}680 \\
460 \\
420 \\
530 \\
1030 \\
580 \\
-\end{array}$ \\
\hline 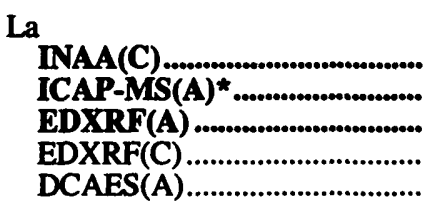 & $\begin{array}{c}10.1 \\
7.7 \\
8.2 \\
16 \\
6.9\end{array}$ & $\begin{array}{l}5.35 \\
4.0 \\
6 \\
6.1\end{array}$ & $\begin{array}{l}6.10 \\
5.9 \\
\overline{15} \\
9.3\end{array}$ & $\begin{array}{c}6.15 \\
4.6 \\
{[4.4]} \\
9 \\
5.8\end{array}$ & $\begin{array}{l}\mathbf{6 . 7 6} \\
\mathbf{5 . 6 7} \\
2.2 \\
5 \\
7.2\end{array}$ & $\begin{array}{c}3.31 \\
2.5 \\
10 \\
2.9\end{array}$ & $\begin{array}{l}21.5 \\
17 \\
17 \\
16 \\
14\end{array}$ & $\begin{array}{l}2.82 \\
1.9 \\
-8 \\
3.7\end{array}$ \\
\hline 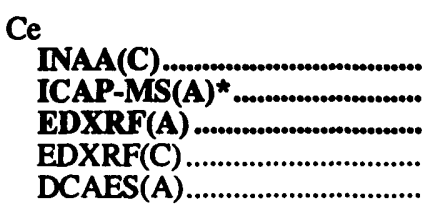 & $\begin{array}{l}18.3 \\
17.6 \\
17.0 \\
40 \\
(10)\end{array}$ & $\begin{array}{l}9.4 \\
8.0 \\
{[5.2]} \\
25 \\
9\end{array}$ & $\begin{array}{c}12.6 \\
12 \\
7.2 \\
40 \\
(28)\end{array}$ & $\begin{array}{r}11.3 \\
10.3 \\
9.0 \\
17 \\
-\end{array}$ & $\begin{array}{c}11.6 \\
11.3 \\
7.6 \\
10 \\
12\end{array}$ & $\begin{array}{c}4.81 \\
4.7 \\
\frac{-}{15} \\
6.9\end{array}$ & $\begin{array}{l}35.8 \\
37.1 \\
29.9 \\
55 \\
26\end{array}$ & $\begin{array}{c}4.45 \\
4.1 \\
- \\
19 \\
-\end{array}$ \\
\hline 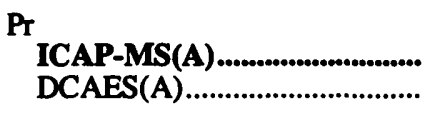 & $\begin{array}{l}1.93 \\
-\end{array}$ & $\stackrel{.926}{-}^{9}$ & 1.3 & $\begin{array}{l}1.12 \\
-\end{array}$ & 1.29 & $\begin{array}{l}.546 \\
.42\end{array}$ & $\begin{array}{c}4.06 \\
{[1.87]}\end{array}$ & $\stackrel{.43}{-}$ \\
\hline 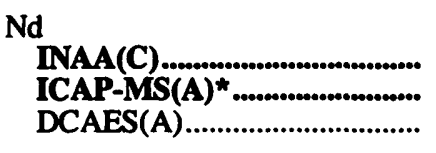 & $\begin{array}{l}(8.0) \\
7.5 \\
8\end{array}$ & $\frac{-}{3.6}$ & $\begin{array}{l}\overline{5.2} \\
(6.5)\end{array}$ & $\begin{array}{l}\overline{4.3} \\
3.9\end{array}$ & $\begin{array}{l}5.1 \\
6.0\end{array}$ & $\begin{array}{c}2.0 \\
2.1 \\
(2.9)\end{array}$ & $\begin{array}{l}11.9 \\
15 \\
19\end{array}$ & $\begin{array}{l}2.3 \\
1.5 \\
-\end{array}$ \\
\hline 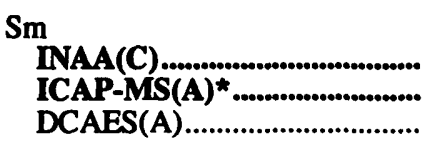 & $\begin{array}{l}1.97 \\
1.55 \\
-\end{array}$ & $\begin{array}{l}.978 \\
.71 \\
-\end{array}$ & $\begin{array}{l}1.20 \\
1.0 \\
-\end{array}$ & $\begin{array}{r}1.10 \\
.83 \\
-\end{array}$ & $\begin{array}{l}1.22 \\
.995 \\
.76\end{array}$ & $\begin{array}{l}.508 \\
.37 \\
.37\end{array}$ & $\begin{array}{r}3.52 \\
2.80 \\
{[1.7]}\end{array}$ & $\begin{array}{l}.409 \\
.26 \\
(.47)\end{array}$ \\
\hline 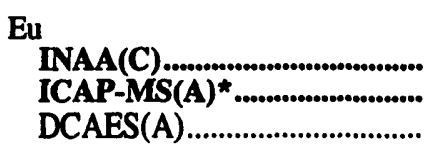 & $\begin{array}{l}.398 \\
.34 \\
-\end{array}$ & $\begin{array}{l}.198 \\
.17 \\
-\end{array}$ & $\begin{array}{l}.226 \\
.20 \\
-\end{array}$ & $\begin{array}{l}.214 \\
.17 \\
-\end{array}$ & $\begin{array}{l}.234 \\
.21 \\
-\end{array}$ & $\begin{array}{r}.099 \\
.084 \\
(.11)\end{array}$ & $\begin{array}{l}.674 \\
.61 \\
.61\end{array}$ & $\begin{array}{l}.081 \\
.054 \\
-\end{array}$ \\
\hline $\begin{array}{l}\text { Tb } \\
\text { INAA(C) } \ldots \ldots \ldots \ldots \ldots \ldots \ldots \ldots \ldots \ldots\end{array}$ & $\begin{array}{l}.262 \\
.23\end{array}$ & $\begin{array}{l}.120 \\
.10\end{array}$ & $\begin{array}{l}.138 \\
.14\end{array}$ & $\begin{array}{l}.132 \\
.11\end{array}$ & $\begin{array}{l}.167 \\
.16\end{array}$ & $\begin{array}{l}.058 \\
.055\end{array}$ & $\begin{array}{l}.400 \\
.40\end{array}$ & $\begin{array}{l}.056 \\
.055\end{array}$ \\
\hline 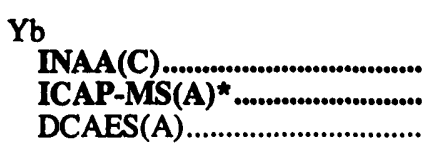 & $\begin{array}{l}.88 \\
.81 \\
.84\end{array}$ & $\begin{array}{l}.42 \\
.37 \\
.29\end{array}$ & $\begin{array}{l}.52 \\
.52 \\
.61\end{array}$ & $\begin{array}{l}.470 \\
.43 \\
.54\end{array}$ & $\begin{array}{l}.555 \\
.572 \\
.45\end{array}$ & $\begin{array}{l}.204 \\
.20 \\
.21\end{array}$ & $\begin{array}{l}1.61 \\
1.5 \\
1.5\end{array}$ & $\begin{array}{l}.287 \\
.23 \\
.20\end{array}$ \\
\hline $\begin{array}{l}\text { Hf } \\
\text { INAA(C).................................... } \\
\text { ICAP-MS(A)*...................... }\end{array}$ & $\begin{array}{l}.66 \\
.85\end{array}$ & $\begin{array}{l}.601 \\
.68\end{array}$ & $\begin{array}{l}.55 \\
.76\end{array}$ & $\begin{array}{l}.50 \\
.61\end{array}$ & $\begin{array}{l}.438 \\
.56\end{array}$ & $\begin{array}{l}.478 \\
.56\end{array}$ & $\begin{array}{l}1.83 \\
2.3\end{array}$ & $\begin{array}{l}.341 \\
.42\end{array}$ \\
\hline 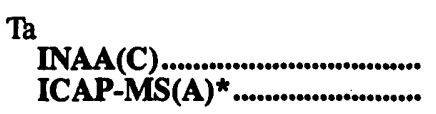 & $\begin{array}{l}.219 \\
.20\end{array}$ & $\begin{array}{l}.146 \\
.12\end{array}$ & $\begin{array}{l}.191 \\
.18\end{array}$ & $\begin{array}{l}.166 \\
.13\end{array}$ & $\begin{array}{l}.116 \\
.11\end{array}$ & $\begin{array}{l}.048 \\
.046\end{array}$ & $\begin{array}{l}.641 \\
.583\end{array}$ & $\stackrel{.092}{-}$ \\
\hline
\end{tabular}


Table 2. Average concentrations of trace elements in parts per million based on triplicate analyses-Continued.

\begin{tabular}{|c|c|c|c|c|c|c|c|c|}
\hline \multirow{2}{*}{ Element and technique } & \multicolumn{8}{|c|}{ Argonne Premium Coal sample } \\
\hline & UF PC-1 & WY PC-2 & IL PC-3 & PITT PC-4 & POC PC-5 & UT PC-6 & WV PC-7 & ND PC-8 \\
\hline 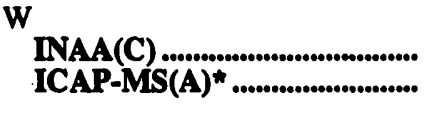 & $\begin{array}{l}1.06 \\
1.2\end{array}$ & $\begin{array}{l}.38 \\
.46\end{array}$ & $\begin{array}{l}1.52 \\
1.62\end{array}$ & $\begin{array}{l}.78 \\
.86\end{array}$ & $\begin{array}{c}.84 \\
1.1\end{array}$ & $\begin{array}{l}.42 \\
.51\end{array}$ & $\begin{array}{c}1.68 \\
{[1.6]}\end{array}$ & $\begin{array}{l}.35 \\
.36\end{array}$ \\
\hline 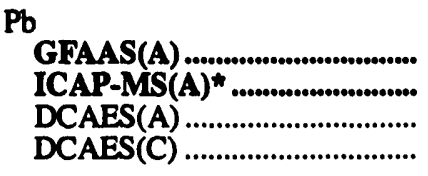 & $\begin{array}{c}7.4 \\
7.6 \\
10 \\
8\end{array}$ & $\begin{array}{r}2.9 \\
1.6 \\
3.4 \\
-\end{array}$ & $\begin{array}{c}6.5 \\
8.5 \\
14 \\
8\end{array}$ & $\begin{array}{r}2.9 \\
3.8 \\
7.3 \\
4\end{array}$ & $\begin{array}{c}2.4 \\
1.7 \\
11 \\
5\end{array}$ & $\begin{array}{l}{[1.6]} \\
1.5 \\
1.9 \\
-\end{array}$ & $\begin{array}{l}12 \\
12 \\
16 \\
-\end{array}$ & $\begin{array}{l}1.5 \\
1.6 \\
2.6 \\
-\end{array}$ \\
\hline 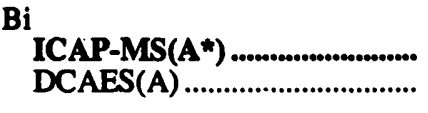 & $\stackrel{.12}{-}$ & $-^{.053}$ & [.088] & $\begin{array}{r}. \mathbf{1 2} \\
{[1.8]}\end{array}$ & $\stackrel{.052}{-}^{.052}$ & $\stackrel{.035}{-}^{.035}$ & $\stackrel{.23}{-}^{.23}$ & $\bar{z}$ \\
\hline 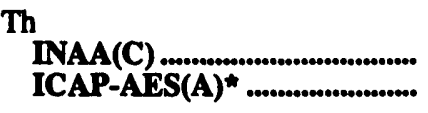 & $\begin{array}{l}2.26 \\
2.7\end{array}$ & $\begin{array}{l}1.71 \\
1.4\end{array}$ & $\begin{array}{l}1.96 \\
2.2\end{array}$ & $\begin{array}{l}1.48 \\
1.6\end{array}$ & $\begin{array}{l}1.16 \\
1.2\end{array}$ & $\begin{array}{l}.615 \\
.58\end{array}$ & $\begin{array}{l}6.41 \\
6.4\end{array}$ & $\begin{array}{c}1.07 \\
.7\end{array}$ \\
\hline 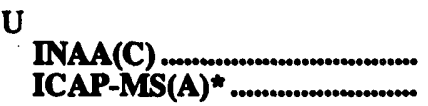 & 1.83 & $\begin{array}{l}.54 \\
.63\end{array}$ & $\begin{array}{l}4.27 \\
6.46\end{array}$ & $\begin{array}{l}.39 \\
.57\end{array}$ & $\begin{array}{l}.51 \\
.631\end{array}$ & $\begin{array}{l}.74 \\
.852\end{array}$ & $\begin{array}{l}1.64 \\
2.16\end{array}$ & $\begin{array}{c}{[.49]} \\
.45\end{array}$ \\
\hline
\end{tabular}

geometric mean, the deviation of the arithmetic and geometric means, and an analysis of the kurtosis and skewness for the HP techniques excluding outliers (values with only one significant figure and HP values excluded because of the $\mathbf{4 0}$ percent rule discussed in the next paragraph). A similar analysis for all values, including LP values, outlier values, and other excluded values, is also given in appendix 2.

Another approach to analyzing the data is to define the agreement between techniques in a useful, nonstatistical manner and then discuss individual cases of disagreement. In a practical sense, for major elements (elements with concentrations generally greater than 0.1 percent; table 1 ), procedures are said to have "good accuracy" if the standand deviation of the individual determinations for a given sample determined by a given technique is \pm 5 percent of the mean of all of the HP procedures and does not disagree by more than \pm 0.5 pecent absolute. For trace elements (table 2) "good agreement" is defined as \pm 10 percent of the mean. "Usable agreement" is four times the uncertainty of "good agreement" or \pm 20 percent for the majors and \pm 40 percent for the traces. Excluded from the agreement analysis were values of only one significant figure. If more than two tests were used, a mean value for a given technique differing by more than 40 percent from the mean of the remaining values was reason for excluding a given technique. This is the " 40 percent rule." The excluded technique was said to have poor agreement for elements in those samples. In addition, the Grubbs test (Taylor, 1987) was made for all suspected HP outliers, using the mean and standard deviation for all HP techniques. Outliers are reported in table 3 under exceptions. They were excluded from the determination of agree- ment except for cases where the outlier was the only value for an element determined by a given technique. Figure 1 summarizes the decisions required to determine the agreement.

Trace-element criteria were applied to those samples containing elements that are traditionally considered major or minor elements (table 1), but whose mean concentration for HP techniques was less than 0.1 percent. This included phosphorus and manganese for all samples and magnesium, sodium, potassium, and titanium (see table 3 ) for four or more samples. It should be noted that the \pm 5 percent criterion for "good agreement" is better than expected for some HP techniques for some samples as concentrations approach the detection limit. For example, counting errors of as high as 28 percent are reported for potassium by INAA (see paper by Palmer, this volume). The criterion of 20 percent required for "usable agreement" is much smaller than the inherent precision for many of the LP techniques. Skeen and others, in this volume, report possible errors of +50 percent or -33 percent because of the nature of the standards for each of the elements. It is not surprising, therefore, that not all HP techniques have "good agreement" for all samples and that most LP techniques have "poor agreement" for most samples. Most of these disagreements were within \pm 50 percent of the HP mean concentrations, and scatter in intertechnique comparison plots simply demonstrates the poorer precision of the LP techniques. A complete discussion of the precision of all values in this study is beyond the scope of this paper, but an indication of the precision can be obtained by examining appendix 1 and by the relative standard deviation given in appendix 2 . 
Table 3. Agreement between techniques for major elements using data from table 1 and criteria described in text.

[The following abbreviations were used under Exceptions: Samples: 1 = UF PC-1; 2 = WY PC-2; 3 = IL PC-3; 4 = PITT PC-4; $5=$ POC PC-5; $6=$ UT PC-6; $7=$ WV PC-7; $8=$ ND PC-8. Those that differ from the overall agreement are followed by $g=$ good agreement; $u=$ usable agreement; $p=$ poor agreement; or $x=$ no values or only upper limits found. High-precision (HP) techniques are in bold for consistency with other tables. HP values not used to calculate the mean are identified with an $s$ for values with only one significant figure, $f$ for values rejected because of the 40 percent rule (see text), or an o for single values rejected using the Grubbs outlier test (Taylor, 1987). All values including outliers were used to determine overall agreement. The mean of these values was used for comparison in evaluating low-precision values. Sample numbers in parentheses are samples where only single determinations are available. Agreement calculated using trace-element criteria because of low concentration in sample was designated with a t. Material analyzed: $(A)=a s h ;(C)=$ whole coal; $*=$ done in Denver]

\begin{tabular}{|c|c|c|c|c|c|c|c|}
\hline Element & $\begin{array}{l}\text { Exceptions } \\
\text { to major } \\
\text { elements }\end{array}$ & $\begin{array}{c}\text { HP } \\
\text { techniques }\end{array}$ & $\begin{array}{c}\text { Overall } \\
\text { agreement }\end{array}$ & Exceptions & $\begin{array}{c}\text { LP } \\
\text { techniques }\end{array}$ & $\begin{array}{c}\text { Overall } \\
\text { agreement }\end{array}$ & Exceptions \\
\hline $\mathrm{Si}$ & 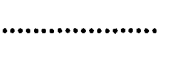 & $\begin{array}{l}\text { ICAP-AES(A)* } \\
\text { WDXRF(A) }\end{array}$ & $\begin{array}{l}\text { Good } \\
\text { Good }\end{array}$ & $\begin{array}{l}2 u, 3 o, 8= \\
2,4,5 u,(8) \text { ou }\end{array}$ & $\begin{array}{l}\text { DCAES(A) } \\
\text { DCAES(C) }\end{array}$ & $\begin{array}{l}\text { Usable } \\
\text { Poor }\end{array}$ & $\begin{array}{l}3,6,7 g ; 2,4,5 p \\
3 s g ; 1 s, 4 s, 5 u ; 6-8 x\end{array}$ \\
\hline Al .................. & 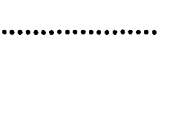 & $\begin{array}{l}\text { WDXRF(A) } \\
\text { ICAP-AES(A) } \\
\text { ICAP-AES(A)* }\end{array}$ & $\begin{array}{l}\text { Good } \\
\text { Good } \\
\text { Good }\end{array}$ & $\begin{array}{l}(8) \mathrm{ou} \\
(6) \mathrm{u} \\
30,40,50\end{array}$ & $\begin{array}{l}\operatorname{DCAES}(\mathbf{A}) \\
\operatorname{DCAES}(\mathrm{C})\end{array}$ & $\begin{array}{l}\text { Poor } \\
\text { Poor }\end{array}$ & $\begin{array}{l}6 u \\
1 s, 3 s, 4 s ; 6-8 x\end{array}$ \\
\hline $\mathrm{Fe}$ & 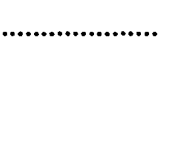 & $\begin{array}{l}\text { INAA(C) } \\
\text { WDXRF(A) } \\
\text { ICAP-AES(A) } \\
\text { ICAP-AES(A)* }\end{array}$ & $\begin{array}{l}\text { Good } \\
\text { Good } \\
\text { Good } \\
\text { Good }\end{array}$ & $\begin{array}{l}6,8 u \\
1,2,4,(8) u \\
6 u \\
1,3,4,8 u\end{array}$ & $\begin{array}{l}\text { DCAES(A) } \\
\text { DCAES(C) }\end{array}$ & $\begin{array}{l}\text { Usable } \\
\text { Usable }\end{array}$ & $\begin{array}{l}5 g ; 2,4,8 p \\
3 s, 4 s, 5 p ; 6-8 x ; 1 s\end{array}$ \\
\hline 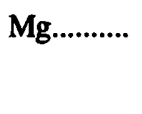 & $1,3-7 \mathrm{t}$ & $\begin{array}{l}\text { WDXRF(A) } \\
\text { ICAP-AES(A) } \\
\text { ICAP-AES(A)* }\end{array}$ & $\begin{array}{l}\text { Usable } \\
\text { Good } \\
\text { Good }\end{array}$ & $\begin{array}{l}1 \mathrm{~g} ;(6) \mathrm{p} ; 3 \mathrm{~s}, 4 \mathrm{~s},(7) \mathrm{s} \\
2,8 \mathrm{u}\end{array}$ & $\begin{array}{l}\text { DCAES(A) } \\
\text { DCAES(C) }\end{array}$ & $\begin{array}{l}\text { Poor } \\
\text { Usable }\end{array}$ & $\begin{array}{l}7 g ; 6 u \\
6-8 x\end{array}$ \\
\hline Са............. & $7 t$ & $\begin{array}{l}\text { WDXRF(A) } \\
\text { ICAP-AES(A) } \\
\text { ICAP-AES(A)* }\end{array}$ & $\begin{array}{l}\text { Good } \\
\text { Good } \\
\text { Good }\end{array}$ & $\begin{array}{l}(7) s \\
1,2 u \\
2,4 u ; 60\end{array}$ & $\begin{array}{l}\text { DCAES(A) } \\
\text { DCAES(C) }\end{array}$ & $\begin{array}{l}\text { Poor } \\
\text { Poor }\end{array}$ & $\begin{array}{l}2,7,8 u \\
2 s u ; 6-8 x ; 3 s\end{array}$ \\
\hline $\mathrm{Na} . . . . . . . . .$. & $1,4,5,7 \mathrm{t}$ & $\begin{array}{l}\operatorname{INAA}(\mathbf{C}) \\
\operatorname{ICAP}-\mathbf{A E S}(\mathbf{A}) \\
\text { ICAP-AES(A)* } \\
\text { WDXRF(A) }\end{array}$ & $\begin{array}{l}\text { Good } \\
\text { Good } \\
\text { Good } \\
\text { Usable }\end{array}$ & $\begin{array}{l}6-8 u \\
3,5,6,8 u \\
2 u \\
(8) g ;(7) s p ; 1 s, 4 s\end{array}$ & DCAES(A) & Usable & $4,7 \mathrm{~g} ; 3,5,6,(8) \mathrm{p}$ \\
\hline $\mathbf{K} \ldots \ldots \ldots$ & $2,5,6,8 \mathrm{t}$ & $\begin{array}{l}\text { INAA(C) } \\
\text { WDXRF(A) } \\
\text { ICAP-AES(A) } \\
\text { ICAP-AES(A)* }\end{array}$ & $\begin{array}{l}\text { Good } \\
\text { Good } \\
\text { Usable } \\
\text { Good }\end{array}$ & $\begin{array}{l}6,8 \mathrm{u} \\
(6) \mathrm{su} ; 2 \mathrm{~s}, 5 \mathrm{~s},(8) \mathrm{s} \\
1,3,4,7 \mathrm{~g} ; 8 \mathrm{fp} \\
2,3,5,8 \mathrm{u}\end{array}$ & DCAES(A) & Usable & $3,7 p$ \\
\hline Ti............. & $1-6,8 t$ & $\begin{array}{l}\text { WDXRF(A) } \\
\text { ICAP-AES(A) } \\
\text { ICAP-AES(A)* }\end{array}$ & $\begin{array}{l}\text { Good } \\
\text { Good } \\
\text { Good }\end{array}$ & (6)su:3s,(8)s & $\begin{array}{l}\text { DCAES(A) } \\
\text { DCAES(C) }\end{array}$ & $\begin{array}{l}\text { Usable } \\
\text { Usable }\end{array}$ & $\begin{array}{l}3,4,8 \mathrm{~g} ; 7 \mathrm{p} \\
4,5 \mathrm{p} ; 6-8 \mathrm{x}\end{array}$ \\
\hline P................... & $1-8 t$ & $\begin{array}{l}\text { WDXRF(A) } \\
\text { ICAP-AES(A) } \\
\text { ICAP-AES(A)* }\end{array}$ & $\begin{array}{l}\text { Good } \\
\text { Good }\end{array}$ & $\begin{array}{c}\text { 4sg;(8)sp;1s,2s, } \\
\text { 3s,5s;(6)s,(7)s } \\
1,4,6 u ; 3,7= \\
1,4 ; 3 \mathrm{~s}, 6 \mathrm{su} ; 7 \mathrm{~s}\end{array}$ & $\begin{array}{l}\text { WDXRF(C) } \\
\text { DCAES }(A)\end{array}$ & $\begin{array}{l}\text { Poor } \\
\text { Poor }\end{array}$ & $\begin{array}{l}\text { 4sg;2su;8sp;1,3,5-7x } \\
8 \mathrm{~g} ; 7 \mathrm{p} ; 1,3-5 \mathrm{x}\end{array}$ \\
\hline Mn............... & $1-8 t$ & $\begin{array}{l}\text { WDXRF(A) } \\
\text { ICAP-AES(A) } \\
\text { ICAP-AES(A)* }\end{array}$ & $\begin{array}{l}\text { Usable } \\
\text { Good } \\
\text { Good }\end{array}$ & $1-7 x, 8 s g$ & $\begin{array}{l}\text { DCAES(A) } \\
\text { DCAES(C) }\end{array}$ & $\begin{array}{l}\text { Usable } \\
\text { Usable }\end{array}$ & $\begin{array}{l}2,3,4,6 p \\
4 g ; 3 p ; 6-8 x\end{array}$ \\
\hline
\end{tabular}




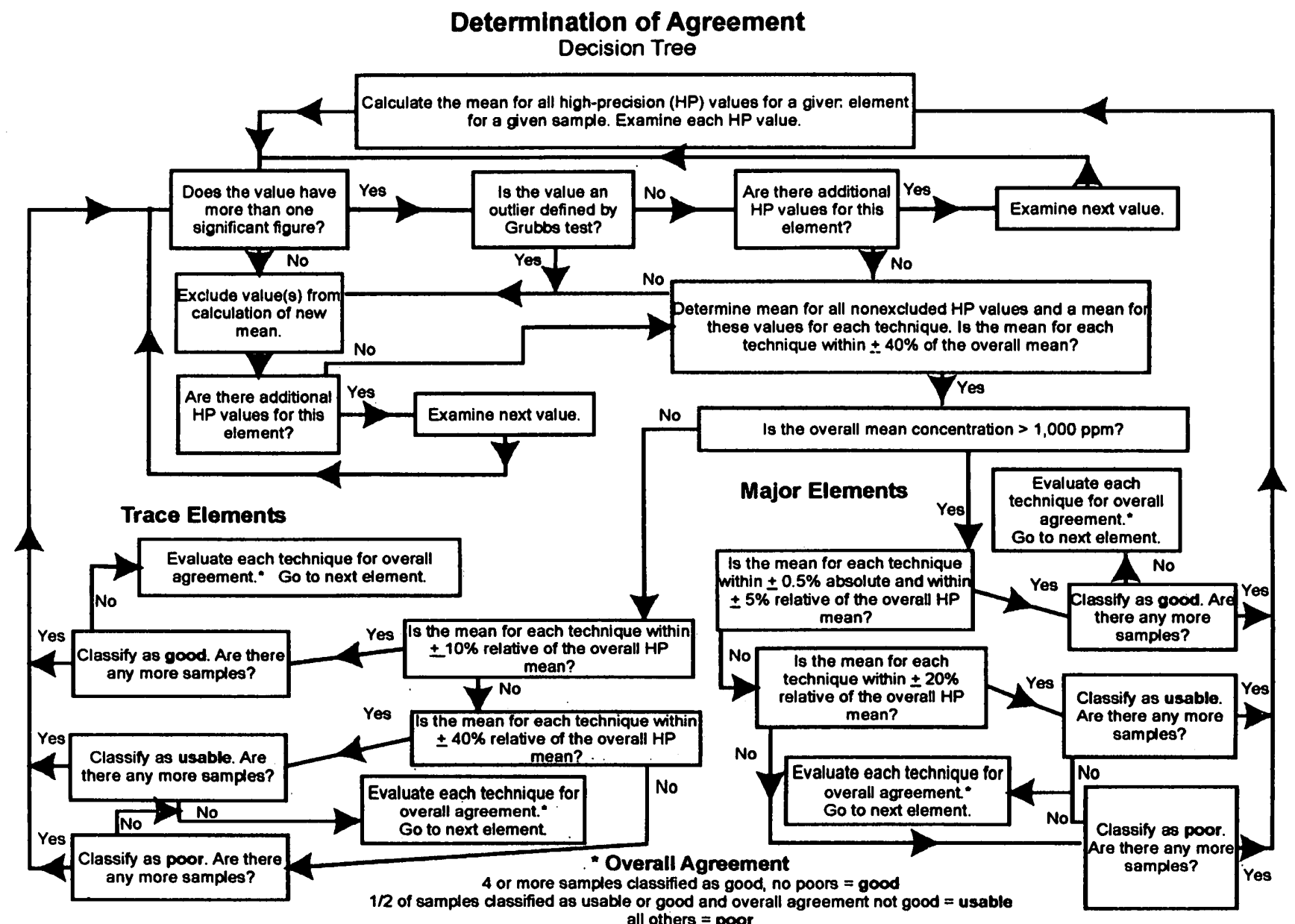

Figure 1. Decision tree for determination of agreement between techniques for each element.

A summary of the agreement for major elements is given in table 3. Data for elements by specific techniques were classified as in "overall good agreement" with the mean of the HP procedures if at least half of the individual samples were in "good agreement" using the previously mentioned criteria, and no samples had "poor agreement." If half or more of the samples determined were in "good" or "usable agreement" and the technique was not classified as in "good agreement," the element had "overall usable agreement." All others had "overall poor agreement" except where the technique was the only HP technique. In this case, agreement could not be determined. The mean of the samples for this sole HP technique was used to assess the agreement of the LP techniques, and no accuracy designation was given. All HP techniques listed in table 3 were in "overall good agreement" except for sodium, magnesium, manganese, and phosphorus determined by WDXRF on the ash, and potassium determined by ICAP-AES in Reston. These were classified as having "overall usable agreement."
In contrast, all LP techniques had "overall poor" or "overall usable agreement."

Table 4 summarizes the agreement of trace elements. All agreements were evaluated using trace-element criteria discussed previously and summary classifications similar to those in table 3. HP procedures generally had "good agreement" and none had "poor agreement," whereas LP procedures generally had "usable" or "poor agreement," with only an occasional "good agreement."

Most of the data fall within expected precision limits, but barium is an example of a case where determining an element by more than one technique can make a significant difference. Agreement between techniques can be graphically represented by plotting the concentrations of all elements determined by one technique versus all corresponding concentrations by a second technique and comparing these points to a theoretical line with zero intercept and a slope of 1. Figure 2, for example, shows the comparison of INAA and ICAP-AES data from table 2 for all elements that the two techniques have in common. There is relatively little 
Table 4. Agreement between techniques for trace elements using data from table 2 and criteria described in text.

[The following abbreviations were used under Exceptions: Samples: $1=$ UF PC-1; 2 = WY PC-2; 3 = IL PC-3; 4 = PITT PC-4; 5 = POC PC. $5 ; 6=$ UT PC-6; $7=$ WV PC-7; $8=$ ND PC-8. Those that differ from the overall agreement are followed by $g=$ good agreement; $u=u s a b l e$ agreement; $p=$ poor agreement; or $x=$ no values or only upper limits found. High-precision (HP) techniques are in bold for consistency with other tables. HP values not used to calculate the mean are identified with an $s$ for values with only one significant figure, an $f$ for values rejected because of the 40 percent rule (see text), or an o for single values rejected using the Grubbs outlier test (Taylor, 1987). All values including outliers were used to determine overall agreement. Equal sign " $=$ " indicates there are no other high-precision values; italicized "good" agreements indicate that the only high-precision techniques used in determining the accuracy were modifications of the same tests, ICAP-AES(A) done in Reston and Denver. The mean of these values was used for comparison in evaluating low-precision values. Sample numbers in parentheses are samples where only single determinations are available. Material analyzed: $(A)=$ ash; $(C)=$ whole coal; * $=$ done in Denver. - , no agreement could be calculated]

\begin{tabular}{|c|c|c|c|c|c|c|}
\hline Element & $\begin{array}{c}\text { HP } \\
\text { techniques }\end{array}$ & $\begin{array}{c}\text { Overall } \\
\text { agreement }\end{array}$ & Exceptions & $\begin{array}{c}\text { LP } \\
\text { techniques }\end{array}$ & $\begin{array}{l}\text { Overall } \\
\text { agreement }\end{array}$ & Exceptions \\
\hline $\mathrm{Li}$ & $\begin{array}{l}\text { FAAS(A) } \\
\text { ICAP-AES(A)* }\end{array}$ & $\begin{array}{l}\text { Good } \\
\text { Good }\end{array}$ & & & & \\
\hline \multirow{2}{*}{$\mathrm{Be}$} & ICAP-AES(A) & Good & & DCAES(A) & Poor & $1 \mathrm{~g} ; 3,5 \mathrm{u}$ \\
\hline & ICAP-AES(A)* & Good & $2 s, 3 s, 6 s u ; 4 s, 8 s$ & & & \\
\hline В & ICAP-AES(A)* & - & $1-8=$ & DCAES(A) & Usable & $4,7 \mathrm{~g} ; 6 \mathrm{x}$ \\
\hline 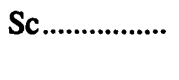 & $\begin{array}{l}\operatorname{INAA}(\mathbf{C}) \\
\text { ICAP-AES(A)* }\end{array}$ & $\begin{array}{l}\text { Good } \\
\text { Good }\end{array}$ & $\begin{array}{l}8= \\
8 s\end{array}$ & DCAES(A) & Usable & $3,8 \mathrm{~g} ; 1 \mathrm{p}$ \\
\hline 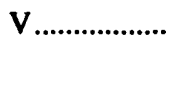 & $\begin{array}{l}\text { ICAP-AES(A) } \\
\text { ICAP-AES(A)* }\end{array}$ & $\begin{array}{l}\text { Good } \\
\text { Good }\end{array}$ & & $\begin{array}{l}\operatorname{DCAES}(A) \\
\operatorname{DCAES}(C)\end{array}$ & $\begin{array}{l}\text { Usable } \\
\text { Poor }\end{array}$ & $\begin{array}{l}8 g \\
2 g ; 6-8 x\end{array}$ \\
\hline \multirow[t]{2}{*}{ 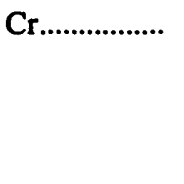 } & $\operatorname{INAA}(\mathbf{C})$ & Good & $7 \mathbf{u}$ & $\operatorname{EDXRF(C)}$ & Usable & $\begin{array}{l}3 \mathrm{~g} ; 4 \mathrm{~s}, 5 \mathrm{sp} ; 6,8 \mathrm{x} ; \\
2 \mathrm{~s}\end{array}$ \\
\hline & $\begin{array}{l}\operatorname{EDXRF}(\mathbf{A}) \\
\text { ICAP-AES(A) } \\
\text { ICAP-AES(A)* }\end{array}$ & $\begin{array}{l}\text { Usable } \\
\text { Good } \\
\text { Good }\end{array}$ & $\begin{array}{l}8 \mathrm{~g} ; 6 \mathrm{x} ; 20 \\
3,4 \mathrm{u}\end{array}$ & $\begin{array}{l}\text { DCAES(A) } \\
\operatorname{DCAES}(C)\end{array}$ & $\begin{array}{l}\text { Good } \\
\text { Poor }\end{array}$ & $\begin{array}{l}1,2,4,5 u \\
2 s g ; 6-8 x\end{array}$ \\
\hline \multirow[t]{2}{*}{ Co } & $\begin{array}{l}\text { WNAA(C) } \\
\text { FAAS(A) }\end{array}$ & $\begin{array}{l}\text { Good } \\
\text { Good }\end{array}$ & $\begin{array}{l}8= \\
6 u ; 8 x\end{array}$ & $\begin{array}{l}\operatorname{DCAES}(\mathrm{A}) \\
\operatorname{DCAES}(\mathrm{C})\end{array}$ & $\begin{array}{l}\text { Usable } \\
\text { Usable }\end{array}$ & $\begin{array}{l}4 g \\
1 \mathrm{sg} ; 2-4,6-8 x ; \\
\quad 5 s\end{array}$ \\
\hline & ICAP-AES(A)* & Good & $8 s u$ & & & \\
\hline $\mathrm{Ni} . . . . . . . . . . . . . .$. & $\begin{array}{l}\text { NAA(C) } \\
\text { EDXRF(A) } \\
\text { ICAP-AES(A) } \\
\text { ICAP-AES(A)* }\end{array}$ & $\begin{array}{l}\text { Good } \\
\text { Good } \\
\text { Good } \\
\text { Good }\end{array}$ & $\begin{array}{l}4,5 u ; 8 x \\
2,8 u ; 6 x \\
5,8 u \\
1,30 u\end{array}$ & $\begin{array}{l}\operatorname{EDXRF}(C) \\
\operatorname{DCAES}(A) \\
\operatorname{DCAES}(\mathrm{C})\end{array}$ & $\begin{array}{l}\text { Poor } \\
\text { Usable } \\
\text { Poor }\end{array}$ & $\begin{array}{l}7 u ; 2 s, 6 s, 8 s \\
1 g ; 4 p \\
4 u ; 2,6-8 x\end{array}$ \\
\hline $\mathrm{Cu} \ldots \ldots \ldots \ldots . . . . .$. & $\begin{array}{l}\operatorname{EDXRF}(\mathbf{A}) \\
\text { ICAP-AES(A) } \\
\text { ICAP-AES(A)* }\end{array}$ & $\begin{array}{l}\text { Good } \\
\text { Good } \\
\text { Usable }\end{array}$ & $\begin{array}{l}7,8 \mathrm{u} ; 6 \mathrm{x} \\
5,7,8 \mathrm{u} \\
1-4,6,7 \mathrm{~g} ; 8 \mathrm{op}\end{array}$ & $\begin{array}{l}\text { EDXRF(C) } \\
\text { DCAES(A) } \\
\text { DCAES(C) }\end{array}$ & $\begin{array}{l}\text { Usable } \\
\text { Usable } \\
\text { Usable }\end{array}$ & $\begin{array}{l}1 \mathrm{~g} ; 4,6 \mathrm{~s}, 7,8 \mathrm{sp} \\
2,3 \mathrm{~g} ; 5 \mathrm{p} \\
1,4 \mathrm{~g} ; 2,5 \mathrm{p} ; 6-8 \mathrm{x}\end{array}$ \\
\hline \multirow[t]{2}{*}{$\mathbf{Z n}$} & $\begin{array}{l}\operatorname{NAA}(\mathbf{C}) \\
\operatorname{EDXRF(A)}\end{array}$ & $\begin{array}{l}\text { Good } \\
\text { Usable }\end{array}$ & $\begin{array}{l}3,5,8 \mathrm{u} \\
1,2,4,5,7,8 \mathrm{~g} ; 3 \mathrm{fp}, 6 \mathrm{x}\end{array}$ & $\operatorname{EDXRF(C)}$ & Poor & $8 s g ; 3,7 u ; 6 x$ \\
\hline & $\begin{array}{l}\text { ICAP-AES(A) } \\
\text { ICAP-AES(A)* }\end{array}$ & $\begin{array}{l}\text { Good } \\
\text { Good }\end{array}$ & $\begin{array}{l}5,8 u \\
40,6 u\end{array}$ & DCAES(C) & Poor & $2,5-8 x$ \\
\hline $\mathrm{Ga} . . . . . . . . . . . . .$. & ICAP-AES(A)* & - & $1-8=$ & $\begin{array}{l}\operatorname{DCAES}(A) \\
\operatorname{DCAES}(C)\end{array}$ & $\begin{array}{l}\text { Usable } \\
\text { Poor }\end{array}$ & 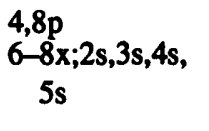 \\
\hline $\mathrm{Ge}$ & $\operatorname{ICAP}-\mathbf{M S}(\mathbf{A})^{\star}$ & - & $1-8=$ & $\begin{array}{l}\text { DCAES(A) } \\
\operatorname{DCAES}(C)\end{array}$ & $\begin{array}{l}\text { Usable } \\
\text { Usable }\end{array}$ & $\begin{array}{c}\text { 3,4g;5p;2,6,8x } \\
\text { 1s,3sg;(4)sp; } \\
\text { 2,5-8x }\end{array}$ \\
\hline As ................... & $\begin{array}{l}\text { INAA(C) } \\
\text { ICAP-MS(A)* }\end{array}$ & $\begin{array}{l}\text { Good } \\
\text { Usable }\end{array}$ & $\begin{array}{l}2,3,6,8 \mathrm{u} \\
1,3-5,7 \mathrm{~g} ; 80\end{array}$ & DCAES(A) & Poor & $2,3,6-8 x$ \\
\hline $\mathrm{Se} . . . . . . . . . . . . . .$. & $\begin{array}{l}\text { INAA(C) } \\
\text { HGAAS(C)* }\end{array}$ & $\begin{array}{l}\text { Good } \\
\text { Good }\end{array}$ & $\begin{array}{l}2 u \\
2 u, 70\end{array}$ & & & \\
\hline \multirow[t]{2}{*}{$\mathrm{Rb}$} & INAA(C) & Good & $7,8 u ; 2,5 x$ & $\operatorname{EDXRF}(C)$ & Usable & $\begin{array}{l}1,4 s g ; 2,5 s, 6 s, \\
\quad 8 s p\end{array}$ \\
\hline & $\begin{array}{l}\operatorname{ICAP-MS(A)*} \\
\operatorname{EDXRF(A)}\end{array}$ & $\begin{array}{l}\text { Good } \\
\text { Good }\end{array}$ & $\begin{array}{l}2,8 u \\
2,7 u ; 6,8 x\end{array}$ & & & \\
\hline
\end{tabular}


Table 4. Agreement between techniques for trace elements using data from table 2 and criteria described in textContinued.

\begin{tabular}{|c|c|c|c|c|c|c|}
\hline Element & $\begin{array}{c}\text { HP } \\
\text { techniques }\end{array}$ & $\begin{array}{c}\text { Overall } \\
\text { agreement }\end{array}$ & Exceptions & $\begin{array}{c}\text { LP } \\
\text { techniques }\end{array}$ & $\begin{array}{c}\text { Overall } \\
\text { agreement }\end{array}$ & Exceptions \\
\hline 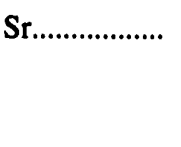 & $\begin{array}{l}\text { INAA(A) } \\
\text { EDXRF(A) } \\
\text { ICAP-AES(A) } \\
\text { ICAP-AES(A)* }\end{array}$ & $\begin{array}{l}\text { Good } \\
\text { Good } \\
\text { Usable } \\
\text { Good }\end{array}$ & $\begin{array}{l}1,3,6 \mathrm{u} \\
7,8 \mathrm{u} ; 6 \mathrm{x} \\
1,4,6 \mathrm{~g} ; 2 \mathrm{fp} \\
8 \mathrm{u}\end{array}$ & $\begin{array}{l}\text { EDXRF(C) } \\
\text { DCAES(A) }\end{array}$ & $\begin{array}{l}\text { Good } \\
\text { Usable }\end{array}$ & $\begin{array}{l}2,5,7,8 \mathrm{u} \\
1,5 \mathrm{~g} ; 4,6 \mathrm{p}\end{array}$ \\
\hline $\mathbf{Y}$ & $\operatorname{EDXRF(A)}$ & Usable & $1-3,5 g ; 6,8 x ; 7 f p$ & $\operatorname{EDXRF}(C)$ & Usable & $\begin{array}{l}\text { (6)sg, } 7 \mathrm{p} ; 1-5 \text {, } \\
8 \mathrm{x}\end{array}$ \\
\hline . & $\begin{array}{l}\text { ICAP-AES(A) } \\
\text { ICAP-AES(A)* }\end{array}$ & $\begin{array}{l}\text { Good } \\
\text { Good }\end{array}$ & $\begin{array}{l}8 u \\
1 u\end{array}$ & DCAES(A) & Usable & $1 p$ \\
\hline $\mathrm{Zr}$ & $\begin{array}{l}\operatorname{ICAP}-\mathbf{A E S}(\mathbf{A}) * \\
\operatorname{EDXRF}(\mathbf{A})\end{array}$ & $\begin{array}{l}\text { Good } \\
\text { Good }\end{array}$ & $\begin{array}{l}8 u, 6= \\
8 u ; 6 x\end{array}$ & $\begin{array}{l}\text { EDXRF(C) } \\
\text { DCAES(A) } \\
\text { DCAES(C) }\end{array}$ & $\begin{array}{l}\text { Usable } \\
\text { Usable } \\
\text { Usable }\end{array}$ & $\begin{array}{l}2,3,6 \mathrm{~g} ; 8 \mathrm{p} \\
1,7,8 \mathrm{p} \\
3 \mathrm{~g} ; 5 \mathrm{p} ; 2,6-8 \mathrm{x}\end{array}$ \\
\hline $\mathrm{Nb}$ & $\begin{array}{l}\operatorname{ICAP}-M S(\mathbf{A}) \star \\
\operatorname{EDXRF}(\mathbf{A})\end{array}$ & $\begin{array}{l}\text { Good } \\
\text { Usable }\end{array}$ & $\begin{array}{l}2,7 \mathrm{u} ; 6,8= \\
1,3,4 \mathrm{~g} ; 6,8 \mathrm{x}\end{array}$ & $\begin{array}{l}\text { EDXRF(C) } \\
\text { DCAES(A) }\end{array}$ & $\begin{array}{l}\text { Poor } \\
\text { Usable }\end{array}$ & $\begin{array}{l}1-6,8 x \\
4,6 g ; 7 p\end{array}$ \\
\hline Mo.................... & $\operatorname{ICAP}-\mathbf{M S}(\mathbf{A}) *$ & - & $1-8=$ & DCAES(A) & Usable & $4 g ; 1,8 p$ \\
\hline Ag ..................... & $\operatorname{ICAP-MS(A)*~}$ & - & $1-8=$ & $\operatorname{DCAES}(\mathrm{A})$ & Poor & $8 x$ \\
\hline $\mathrm{Cd}$ & $\begin{array}{l}\operatorname{ICAP}-M S(\mathbf{A})^{\star} \\
\text { GFAAS(A) }\end{array}$ & $\begin{array}{l}\text { Usable } \\
\text { Usable }\end{array}$ & $\begin{array}{l}5,6,8 \mathrm{~g} ; 1 \mathrm{p} \\
5,8 \mathrm{~g}\end{array}$ & & & \\
\hline 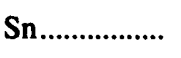 & $\operatorname{ICAP}-\mathbf{M S}(\mathbf{A})^{*}$ & - & $1-8=$ & DCAES(A) & Poor & $7 g$ \\
\hline 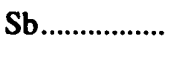 & $\begin{array}{l}\operatorname{INAA}(\mathbf{C}) \\
\operatorname{ICAP}-\mathbf{M S}(\mathbf{A})^{*}\end{array}$ & $\begin{array}{l}\text { Good } \\
\text { Good }\end{array}$ & $\begin{array}{l}5 u \\
5 u\end{array}$ & & & \\
\hline Cs..................... & $\begin{array}{l}\operatorname{INAA}(\mathbf{C}) \\
\text { ICAP-MS(A)* }\end{array}$ & $\begin{array}{l}\text { Good } \\
\text { Good }\end{array}$ & $\begin{array}{l}1,3,7 \mathrm{u} \\
1,3,7 \mathrm{u}\end{array}$ & & & \\
\hline $\mathrm{Ba} \ldots \ldots \ldots \ldots$ & $\begin{array}{l}\text { INAA(C) } \\
\text { EDXRF(A) } \\
\text { ICAP-AES(A) } \\
\text { ICAP-AES(A)* }\end{array}$ & $\begin{array}{l}\text { Good } \\
\text { Good } \\
\text { Usable } \\
\text { Good }\end{array}$ & $\begin{array}{l}3,4,8 \mathrm{u} \\
4,7,8 \mathrm{u} ; 6 \mathrm{x} \\
1,3,4,6,7 \mathrm{~g} ; 2 \mathrm{f}, 5 \mathrm{fp}\end{array}$ & $\begin{array}{l}\text { EDXRF(C) } \\
\text { DCAES(A) } \\
\text { DCAES(C) }\end{array}$ & $\begin{array}{l}\text { Usable } \\
\text { Good } \\
\text { Poor }\end{array}$ & $\begin{array}{l}1 \mathrm{~g} ; 2,3,7,8 \mathrm{p} \\
1,3,8 \mathrm{u} \\
2 \mathrm{u} ; 6-8 \mathrm{x}\end{array}$ \\
\hline \multirow[t]{2}{*}{ 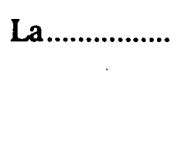 } & $\operatorname{INAA}(\mathbf{C})$ & Usable & $3,5 \mathrm{~g}$ & $\operatorname{EDXRF(C)}$ & Poor & $\begin{array}{l}2 s, 5 s, 7 u ; 4 s, 6 s, \\
\quad 8 s\end{array}$ \\
\hline & $\begin{array}{l}\operatorname{ICAP-MS(A)*} \\
\operatorname{EDXRF(A)}\end{array}$ & $\begin{array}{l}\text { Usable } \\
\text { Usable }\end{array}$ & $\begin{array}{l}5,3,7 \mathrm{~g} \\
1,7 \mathrm{~g} ; 5 \mathrm{fp} ; 2,3,6,8 \mathrm{x}\end{array}$ & DCAES(A) & Usable & $6 g ; 3,8 p$ \\
\hline Ce.................... & $\begin{array}{l}\operatorname{INAA}(\mathbf{C}) \\
\operatorname{ICAP-MS(A)})^{*} \\
\operatorname{EDXRF(A)}\end{array}$ & $\begin{array}{l}\text { Good } \\
\text { Good } \\
\text { Usable }\end{array}$ & $\begin{array}{l}2-5 u \\
3,5 u \\
1 g ; 6,8 x\end{array}$ & $\begin{array}{l}\operatorname{EDXRF}(C) \\
\operatorname{DCAES}(\mathbf{A})\end{array}$ & $\begin{array}{l}\text { Poor } \\
\text { Poor }\end{array}$ & $\begin{array}{l}5 \mathrm{~g} \\
2,5,7 \mathrm{u} ; 4,8 \mathrm{x}\end{array}$ \\
\hline 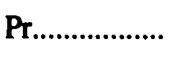 & $\operatorname{ICAP}-\mathbf{M S}(\mathbf{A})^{*}$ & - & $1-8=$ & $\operatorname{DCAES}(\mathrm{A})$ & Poor & $6 u ; 1-5,8 x$ \\
\hline Nd ..................... & $\begin{array}{l}\operatorname{INAA}(\mathbf{C}) \\
\operatorname{ICAP}-\mathbf{M S}(\mathbf{A}) \text { * }\end{array}$ & $\begin{array}{l}\text { Usable } \\
\text { Good }\end{array}$ & $\begin{array}{l}(1), 6 g ; 2-5 x \\
8 u ; 2-5=\end{array}$ & DCAES(A) & Usable & $1 \mathrm{~s}, 4 \mathrm{~g} ; 7 \mathrm{p} ; 2,8 \mathrm{x}$ \\
\hline 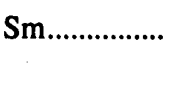 & $\begin{array}{l}\operatorname{INAA}(\mathbf{C}) \\
\operatorname{ICAP-MS}(\mathbf{A})^{*}\end{array}$ & $\begin{array}{l}\text { Usable } \\
\text { Usable }\end{array}$ & $\begin{array}{l}3 \mathrm{~g} \\
3 \mathrm{~g}\end{array}$ & DCAES(A) & Poor & $5,6 u ; 1-4 x$ \\
\hline 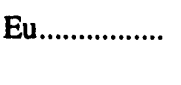 & $\begin{array}{l}\text { INAA(C) } \\
\text { ICAP-MS(A)* }\end{array}$ & $\begin{array}{l}\text { Good } \\
\text { Good }\end{array}$ & $\begin{array}{l}4,8 u \\
4,8 u\end{array}$ & $\operatorname{DCAES}(\mathbf{A})$ & Usable & $6 \mathrm{u}, 7 \mathrm{~g} ; 1-5,8 \mathrm{x}$ \\
\hline 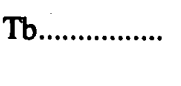 & $\begin{array}{l}\operatorname{INAA}(\mathbf{C}) \\
\operatorname{ICAP-MS(A)*}\end{array}$ & $\begin{array}{l}\text { Good } \\
\text { Good }\end{array}$ & & 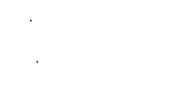 & & \\
\hline Yb .................... & $\begin{array}{l}\text { INAA(C) } \\
\text { ICAP-MS(A)* }\end{array}$ & $\begin{array}{l}\text { Good } \\
\text { Good }\end{array}$ & $\begin{array}{l}8 u \\
8 u\end{array}$ & DCAES(A) & Usable & $1,6,7 \mathrm{~g}$ \\
\hline Hf ..................... & $\begin{array}{l}\text { INAA(C) } \\
\text { ICAP-MS(A)* }\end{array}$ & $\begin{array}{l}\text { Good } \\
\text { Good }\end{array}$ & $\begin{array}{l}1,3,5,7 u \\
1,3,5,7 u\end{array}$ & & & \\
\hline
\end{tabular}


Table 4. Agreement between techniques for trace elements using data from table 2 and criteria described in textContinued.

\begin{tabular}{|c|c|c|c|c|c|c|}
\hline Element & $\begin{array}{c}\text { HP } \\
\text { techniques }\end{array}$ & $\begin{array}{c}\text { Overall } \\
\text { agreement }\end{array}$ & Exceptions & $\begin{array}{c}\text { LP } \\
\text { techniques }\end{array}$ & $\begin{array}{c}\text { Overall } \\
\text { agreement }\end{array}$ & Exceptions \\
\hline Тa........................ & $\begin{array}{l}\operatorname{INAA(C)} \\
\text { ICAP-MS(A)* }\end{array}$ & $\begin{array}{l}\text { Good } \\
\text { Good }\end{array}$ & $\begin{array}{l}4 u ; 8= \\
4 u ; 8 x\end{array}$ & & & \\
\hline 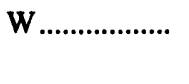 & $\begin{array}{l}\text { INAA(C) } \\
\text { ICAP-MS(A)* }\end{array}$ & $\begin{array}{l}\text { Good } \\
\text { Good }\end{array}$ & $\begin{array}{l}5 \mathrm{u} \\
5 \mathrm{u} ; 70\end{array}$ & & & \\
\hline $\mathrm{Pb}$ & $\begin{array}{l}\text { GFAAS(A) } \\
\text { ICAP-MS(A)* }\end{array}$ & $\begin{array}{l}\text { Good } \\
\text { Good }\end{array}$ & $\begin{array}{l}2-5 u \\
2-5 u\end{array}$ & $\begin{array}{l}\text { DCAES(A) } \\
\text { DCAES(C) }\end{array}$ & $\begin{array}{l}\text { Poor } \\
\text { Usable }\end{array}$ & $\begin{array}{l}1,6,7 \mathrm{u} \\
1 \mathrm{~s}, 3 \mathrm{sg} ; 5 \mathrm{sp} ; 2, \\
\quad 6-8 \mathrm{x} ; 4 \mathrm{~s}\end{array}$ \\
\hline $\mathbf{B i}$.......................... & ICAP-MS(A)* & - & $1-7=, 8 x$ & DCAES(A) & Poor & $1-3,5-8 x$ \\
\hline Th ....................... & $\begin{array}{l}\operatorname{INAA}(\mathbf{C}) \\
\text { ICAP-AES(A)* }\end{array}$ & $\begin{array}{l}\text { Good } \\
\text { Good }\end{array}$ & $\begin{array}{l}8= \\
8 \text { su }\end{array}$ & & & \\
\hline 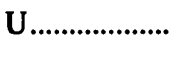 & $\begin{array}{l}\text { INAA(C) } \\
\text { ICAP-MS(A)* }\end{array}$ & $\begin{array}{l}\text { Usable } \\
\text { Usable }\end{array}$ & $\begin{array}{l}2,6,8 \mathrm{~g} \\
2,6,8 \mathrm{~g}\end{array}$ & & & \\
\hline
\end{tabular}

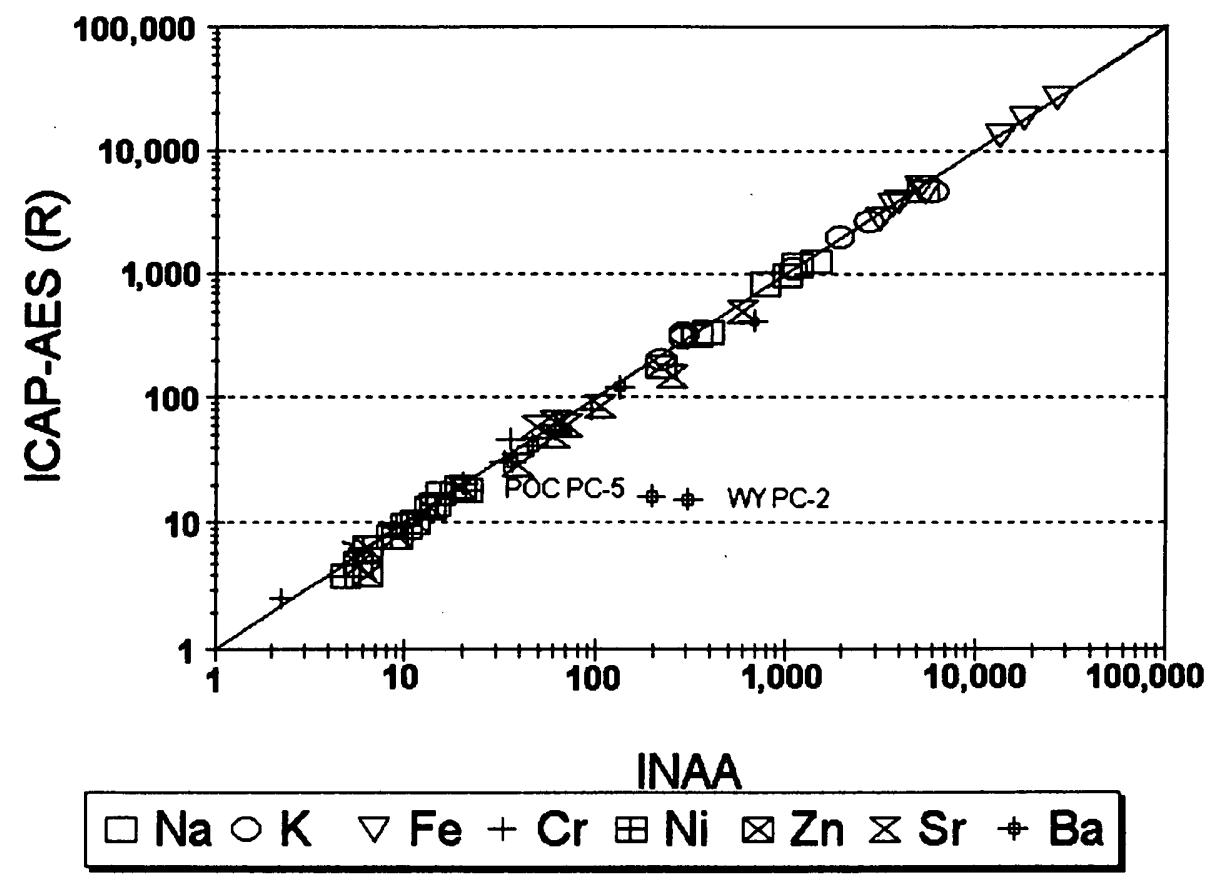

Figure 2. A comparison of average concentrations (in parts per million) of all elements determined by both inductively coupled argon plasma-atomic emission spectrometry in Reston, Va. (ICAP-AES (R)), on the ash and instrumental neutron activation analysis (INAA) on the whole coal. All data determined on the ash are converted to a whole-coal basis. The diagonal line is the line of perfect agreement. 
scatter (excellent agreement) in most of the data; therefore, the few problems with the data are easily recognizable. The most obvious discrepancy in the data is that the barium concentration determined by ICAP-AES is more than an order of magnitude smaller in WY PC-2 and POC PC-5 than the concentration determined by INAA.

The data for barium determined by the seven different techniques are shown in figure 3, plotting barium determined by all techniques versus the mean barium concentration determined by high-precision techniques. Although there is scatter among data from different techniques, ICAP-AES (R) data for WY PC-2 and POC PC-5 are clearly off the correlation line. The disagreement of ICAPAES (R) data with data from all other techniques suggests that barium is present in a species, probably $\mathrm{BaSO}_{4}$, which is not dissolved by the Reston ICAP-AES acid dissolution procedures (see paper by Doughten, this volume). ICAPAES procedures done in Denver use a sinter dissolution procedure and yield $\mathrm{Ba}$ concentrations that agree with the INAA data (see paper by Briggs, this volume). Both of these coals contain enough sulfate sulfur (Vorres, 1990) to account for all barium being $\mathrm{BaSO}_{4}$ in the original coal. Solubility studies of these coals by Finkelman and others
(1990), however, show that barium in these two samples is soluble in ammonium acetate and is therefore readily exchangeable. This suggests that $\mathrm{BaSO}_{4}$ is not in the original samples of WY PC-2 and POC PC-5 but that it is formed in the ashing process. Clearly, the stronger dissolution procedures (see paper by Briggs, this volume) should be used.

Some interesting consequences result from the "agreement" rules. Although zinc determined by EDXRF on the ash had "good agreement" in six samples, the mean of the zinc values for IL PC-3 was only slightly greater than onehalf of the zinc values determined by INAA and ICAP-AES for that sample. This difference led to a classification of "poor agreement" for zinc in IL PC-3 and an overall "usable agreement." Although these results are unusual and can be treated as outliers, as will be discussed later, they relate to the overall reliability of a technique. Outliers also led to usable ratings for copper determined by ICAP-AES (Denver), arsenic determined by ICAP-AES (Denver), yttrium determined by EDXRF, and barium determined by ICAPAES (Reston). Barium had only "overall usable agreement" because of the "poor agreement" in WY PC-2 and POC PC5 , probably caused by incomplete dissolution. Strontium,

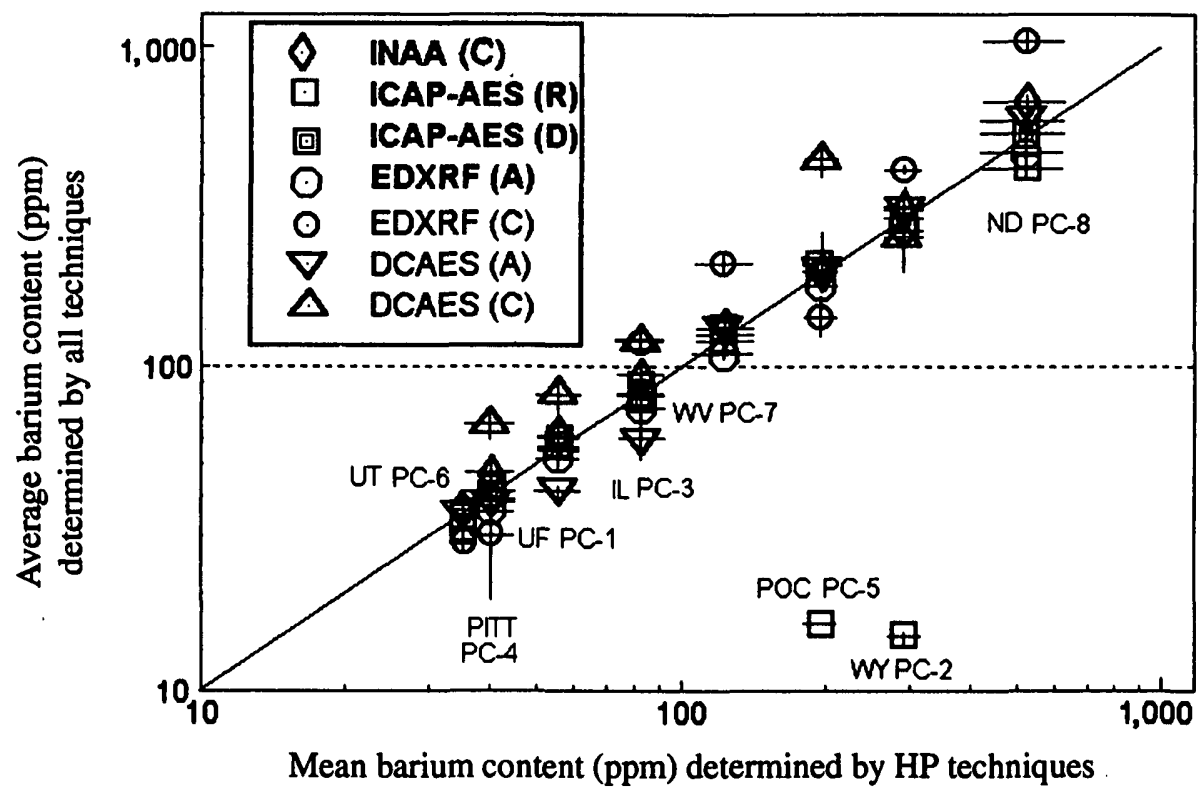

Figure 3. The comparison of mean concentration (in parts per million, ppm) in eight Argonne Premium Coal samples of barium determined by all high-precision techniques excluding outliers with the average concentrations of barium determined by all techniques. All plotted data are determined on, or converted to, a whole-coal basis. The diagonal line is the line of perfect agreement. The high-precision techniques in the legend are in bold. All techniques are defined in appendix 1 ; letters in parentheses have the following meanings: $\mathbf{C}$, determined on whole coal; A, determined on ash (but converted to a whole-coal basis for this figure); $\mathbf{R}$, analysis performed on ash by the U.S. Geological Survey (USGS) in Reston, Va.; D, analysis performed on ash by the USGS in Denver, Colo. Error bars given are the range in the $y$ direction and the standard deviation of the mean in the $x$ direction. 
Table 5. Recommended or average values for major elements in percentages, determined only by high-precision (HP) techniques using the criteria described in text.

[Parentheses indicate that the value is only an average of concentrations determined by the HP techniques and is not a recommended value. Complete data set is given in appendix 1. Statistical analysis of all values, including errors and criteria for not recommending values, is given in appendix 2 . "Excluded values" column indicates that the specified HP techniques were not used in determining the given value. The bracketed numbers with the letters indicate the samples for which the techniques were excluded and the reason the values were rejected. The following abbreviations were used under "Excluded values": 1 = UF PC-1; 2 = WY PC-2; 3 = IL PC-3; 4 = PITT PC-4; 5 = POC PC-5; 6 = UT PC-6; 7 = WV PC-7; 8 = ND PC-8; 0 = determined value was an Qutlier, $\mathrm{s}=$ only one significant figure in all determined values; $\mathrm{f}=$ values rejected because of forty percent rule (see text); and $\mathrm{n}=$ no values were determined or all reported values were upper limits. All techniques referred to under "Excluded values" were determined on the ash]

\begin{tabular}{|c|c|c|c|c|c|c|c|c|c|c|}
\hline & UF PC-1 & WY PC-2 & IL PC-3 & PITT PC-4 & POC PC-5 & UT PC-6 & WV PC-7 & ND PC-8 & $\begin{array}{c}\text { No. HP } \\
\text { techniques }\end{array}$ & $\begin{array}{l}\text { Excluded } \\
\text { values }\end{array}$ \\
\hline 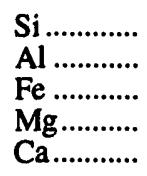 & $\begin{array}{c}2.63 \\
1.58 \\
(1.8) \\
.080 \\
(.42)\end{array}$ & $\begin{array}{r}(1.1) \\
.68 \\
(.35) \\
(.23) \\
(1.12)\end{array}$ & $\begin{array}{l}3.05 \\
1.24 \\
(2.6) \\
.075 \\
.93\end{array}$ & $\begin{array}{c}1.86 \\
.99 \\
(1.33) \\
.036 \\
(.197)\end{array}$ & $\begin{array}{l}0.76 \\
.552 \\
.51 \\
.058 \\
.452\end{array}$ & $\begin{array}{l}0.91 \\
(.37) \\
(.30) \\
(.033) \\
.41\end{array}$ & $\begin{array}{l}5.0 \\
3.16 \\
.39 \\
.090 \\
.058\end{array}$ & $\begin{array}{l}(0.67) \\
.400 \\
(.49) \\
(.38) \\
1.49\end{array}$ & $\begin{array}{l}2 \\
3 \\
4 \\
3 \\
3\end{array}$ & $\begin{array}{l}\text { WDXRF [8o] } \\
\text { WDXRF [8o] } \\
\text { WDXRF [3s,4s,7s] } \\
\text { WDXRF [7s] }\end{array}$ \\
\hline $\begin{array}{l}\mathrm{Na} \\
\mathrm{K}\end{array}$ & $\begin{array}{l}.033 \\
.28\end{array}$ & $\begin{array}{l}(.11) \\
(.030)\end{array}$ & $\begin{array}{l}(.10) \\
(.20)\end{array}$ & $\begin{array}{l}.033 \\
.111\end{array}$ & $\begin{array}{l}.079 \\
(.031)\end{array}$ & $\begin{array}{l}(.135) \\
(.025)\end{array}$ & $\begin{array}{l}.0348 \\
.49\end{array}$ & $\begin{array}{l}(.50) \\
(.034)\end{array}$ & $\begin{array}{l}4 \\
4\end{array}$ & $\begin{array}{l}\text { WDXRF }[1 \mathrm{~s}, 4 \mathrm{~s}, 7 \mathrm{~s}] \\
\text { WDXRF [2s,5s,6s,8s] } \\
\text { ICAP-AES [6f,8f] }\end{array}$ \\
\hline 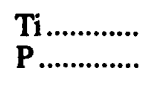 & $\begin{array}{c}.078 \\
(.007)\end{array}$ & $\begin{array}{l}.053 \\
.024\end{array}$ & $\begin{array}{l}.070 \\
(.0059)\end{array}$ & $\begin{array}{l}.055 \\
(.010)\end{array}$ & $\begin{array}{l}.039 \\
.00222\end{array}$ & $\begin{array}{l}.023 \\
(.00095)\end{array}$ & $\begin{array}{l}(.25) \\
(.0083)\end{array}$ & $\begin{array}{l}.0192 \\
.012\end{array}$ & $\begin{array}{l}3 \\
3\end{array}$ & $\begin{array}{l}\text { WDXRF }[3 s, 6 s, 8 s] \\
\text { WDXRF }[1-3 s, 5-8 s] \\
\text { ICAP-AES* }[3 s, 6 s, 7 s]\end{array}$ \\
\hline Mn........... & .0043 & .0020 & .0081 & .0019 & .0017 & .000416 & .00147 & .0081 & 3 & WDXRF [1-8n] \\
\hline
\end{tabular}

determined by ICAP-AES in Reston, showed trends similar to those of barium except to a lesser extent. Strontium had one outlier ("poor"), three "good," and four "usable" values.

All techniques for cadmium, lanthanum, samarium, and uranium showed only overall "usable agreement" even though some samples showed "good agreement" for each of these elements. In these cases it is difficult to determine which technique may be in error. For cadmium, samarium, and uranium, there are only two HP techniques. For years INAA has been considered an excellent technique for the rare earth elements and may provide the best data for lanthanum and samarium. EDXRF is generally not considered to be the best technique for rare earth elements such as lanthanum because of spectral overlaps and values generally near the detection limits. ICAP-MS should produce good results for the rare earth elements but does not always agree well with INAA. This disagreement may be due to incomplete dissolution of some rare-earth-bearing species such as zircon.

Not surprisingly, EDXRF values for cerium yielded only "usable agreement" because cerium concentrations were very near the detection limits for this technique. Other techniques for cerium showed "good agreement." However, chromium determined by EDXRF, well above the detection limit, also showed only "usable agreement," whereas all other techniques showed "good agreement."

The overall agreement of niobium determined by EDXRF and neodymium determined by INAA was usable only because several samples had values at or below the detection limits. Ge, Ga, Mo, Ag, Sn, Pr, and Bi all had only one HP technique, so no rating could be determined. Beryl- lium and vanadium were determined only by ICAP-AES in both Reston and Denver. The "good agreement" that was expected for these techniques is printed in italics in table 4 because these techniques are modifications of the same technique.

The causes of all of the discrepancies are not known. Overall, however, the data are generally useful and provide an excellent base for further study.

\section{DETERMINATION OF RECOMMENDED VALUES}

Because some elements were determined by only one high-precision technique, because some element concentrations approached their detection limits, and because some samples contained interfering elements, recommended values cannot be reliably calculated for all elements in all coals. Tables 5 and 6 present recommended and average values for concentrations determined by high-precision techniques.

Recommended values were determined by using procedures similar to those used in determining agreement ratings. The mean value was considered a recommended value if the relative standard deviation of all individual determinations of HP techniques excluding outliers was less than 5 percent for major elements or 10 percent for trace elements using the criteria discussed earlier, and there were at least four individual determinations. If a recommended value could not be determined, the value for the statistical parameter responsible for rejection was boxed in appendix 2 , and an average of all HP techniques was reported in parentheses 
Table 6. Recommended or average values for trace elements in parts per million, determined only by high-precision (HP) techniques using the criteria described in text.

[Parentheses indicate that the value is only an average of concentrations determined by the HP techniques and is not a recommended value. Complete data set is given in appendix 1 . Statistical analysis of all values, including errors and criteria for not recommending values, is given in appendix 2 . "Excluded values" column indicates that the specified HP techniques were not used in determining the given value. The bracketed numbers with the letters indicate the samples for which the techniques were excluded and the reason the values were rejected. The following abbreviations were used under "Excluded values": 1 = UF PC-1; 2 = WY PC-2; 3 = IL PC-3; 4 = PITT PC-4; 5 = POC PC-5; 6 = UT PC-6; 7 = WV PC-7; 8 = ND PC-8; 0 = determined value was an @utlier, $s=$ only one significant figure in all determined values; $f=$ values rejected because of forty percent rule (see text); and $n=$ no values were determined or all reported values were upper limits. All techniques referred to under "Excluded values" were determined on the ash except INAA, which was determined on the whole coal (* indicates technique was done in Denver). $\rightarrow$, no data]

\begin{tabular}{|c|c|c|c|c|c|c|c|c|c|c|}
\hline & UF PC-1 & WY PC-2 & IL PC-3 & PITT PC-4 & POC PC-5 & UT PC-6 & WV PC-7 & ND PC-8 & $\begin{array}{l}\text { No. HP } \\
\text { techniques }\end{array}$ & $\begin{array}{l}\text { Excluded } \\
\text { values }\end{array}$ \\
\hline $\begin{array}{l}\mathrm{Li} \ldots . . . . . . . . . \\
\mathrm{Be} . . . . . . . . . .\end{array}$ & $\begin{array}{r}14.8 \\
1.5\end{array}$ & $\begin{array}{l}4.0 \\
(.25)\end{array}$ & $\begin{array}{l}7.8 \\
(.76)\end{array}$ & $\begin{array}{l}8.6 \\
(.77)\end{array}$ & $\begin{array}{l}5.6 \\
.80\end{array}$ & $\begin{array}{l}5.3 \\
(.125)\end{array}$ & $\stackrel{28}{2.0}$ & $\begin{array}{l}2.69 \\
(.175)\end{array}$ & $\begin{array}{l}2 \\
2\end{array}$ & $\begin{array}{l}\text { ICAP-AES* }[2-4,6, \\
\quad 8 s]\end{array}$ \\
\hline $\begin{array}{l}\text { B............. } \\
\text { Sc............ } \\
\text { V............ }\end{array}$ & $\begin{array}{c}(38) \\
3.99 \\
26.5\end{array}$ & $\begin{array}{l}(96) \\
1.66 \\
14\end{array}$ & $\begin{array}{c}(160) \\
2.65 \\
35\end{array}$ & $\begin{array}{l}(47.8) \\
2.53 \\
16\end{array}$ & $\begin{array}{c}(13.1) \\
1.78 \\
11.5\end{array}$ & $\begin{array}{c}(127) \\
.78 \\
4.3\end{array}$ & $\begin{array}{r}(56) \\
7.5 \\
43.3\end{array}$ & $\begin{array}{l}(79) \\
(.80) \\
3.7\end{array}$ & $\begin{array}{l}1 \\
2 \\
2\end{array}$ & ICAP-AES* [8s] \\
\hline 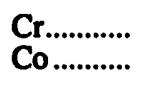 & $\begin{array}{r}(22) \\
5.2\end{array}$ & $\begin{array}{l}(6.5) \\
1.65\end{array}$ & $\begin{array}{l}(36) \\
4.4\end{array}$ & $\begin{array}{l}(16) \\
2.6\end{array}$ & $\begin{array}{l}(10) \\
3.9\end{array}$ & $\begin{array}{c}5.2 \\
.93\end{array}$ & $\begin{array}{l}40 \\
7.8\end{array}$ & $\begin{array}{l}2.4 \\
(.78)\end{array}$ & $\begin{array}{l}4 \\
3\end{array}$ & $\begin{array}{l}\text { EDXRF [6n] } \\
\text { FAAS [8n], } \\
\text { ICAP-AES* [8s\} }\end{array}$ \\
\hline $\mathrm{Ni} . . . . . . . . . . .$. & (15) & (4.7) & (19) & 9.2 & $(7.6)$ & 3.4 & 16 & $(1.5)$ & 4 & EDXRF [6n]; \\
\hline $\begin{array}{l}\mathrm{Cu} \ldots . . . . . . . \\
\mathbf{Z n} \ldots . . . . . .\end{array}$ & $\begin{array}{l}18.9 \\
20\end{array}$ & $\begin{array}{l}13.0 \\
11.0\end{array}$ & $\begin{array}{l}10.1 \\
(200)\end{array}$ & $\begin{array}{l}5.8 \\
8.3\end{array}$ & $\begin{array}{r}(14) \\
(5)\end{array}$ & $\begin{array}{l}4.1 \\
(6)\end{array}$ & $\begin{array}{l}(21) \\
12\end{array}$ & $\begin{array}{l}(4.2) \\
(5.2)\end{array}$ & $\begin{array}{l}3 \\
4\end{array}$ & $\begin{array}{l}\text { INAA [8n] } \\
\text { EDXRF [6n] } \\
\text { EDXRF [3f,6n] }\end{array}$ \\
\hline $\begin{array}{l}\text { Ga ........... } \\
\text { Ge .......... } \\
\text { As .......... } \\
\text { Se........... } \\
\text { Rb.......... }\end{array}$ & $\begin{array}{l}(5.34) \\
(4.35) \\
16.7 \\
(1.9) \\
21\end{array}$ & $\begin{array}{c}(1.9) \\
(.36) \\
(3.0) \\
(2.0) \\
(2.7)\end{array}$ & $\begin{array}{l}(3.57) \\
(8.4) \\
(4.2) \\
(4.2) \\
15.5\end{array}$ & $\begin{array}{c}(3.3) \\
(1.2) \\
8.0 \\
1.6 \\
8.3\end{array}$ & $\begin{array}{c}(1.8) \\
(.29) \\
10.1 \\
(2.7) \\
2.2\end{array}$ & $\begin{array}{c}(1.00) \\
(.23) \\
(.45) \\
(1.2) \\
1.02\end{array}$ & $\begin{array}{c}(9.4) \\
(1.67) \\
(6.4) \\
5.6 \\
(36)\end{array}$ & $\begin{array}{c}(1.16) \\
(.37) \\
(2.4) \\
.59 \\
(1.2)\end{array}$ & $\begin{array}{l}1 \\
1 \\
2 \\
2 \\
3\end{array}$ & $\begin{array}{l}\text { INAA [2n,5n]; } \\
\quad \text { EDXRF }[6 n, 8 n]\end{array}$ \\
\hline Sr ............... & (57) & 257 & (32) & 64 & $(100)$ & 64 & $(60)$ & $(560)$ & 4 & $\begin{array}{l}\text { ICAP-AES [2f]; } \\
\text { EDXRF [6n] }\end{array}$ \\
\hline 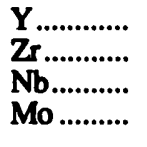 & $\begin{array}{l}(9) \\
26 \\
2.5 \\
(2.5)\end{array}$ & $\begin{array}{c}3.7 \\
(21) \\
(1.2) \\
(.52)\end{array}$ & $\begin{array}{c}(4.1) \\
(23) \\
(2.2) \\
(6.3)\end{array}$ & $\begin{array}{l}(4.4) \\
19 \\
1.8 \\
(.74)\end{array}$ & $\begin{array}{c}6.3 \\
16.5 \\
(1.0) \\
(2.7)\end{array}$ & $\begin{array}{c}2.0 \\
(17.3) \\
(.57) \\
(.42)\end{array}$ & $\begin{array}{l}11.7 \\
75 \\
(7) \\
(1.27)\end{array}$ & $\begin{array}{l}(2.1) \\
(9) \\
(.79) \\
(.41)\end{array}$ & $\begin{array}{l}3 \\
2 \\
2 \\
1\end{array}$ & $\begin{array}{l}\text { EDXRF }[6 n, 8 n, 7 f] \\
\text { EDXRF }[6 n] \\
\text { EDXRF }[6 n, 8 n]\end{array}$ \\
\hline $\begin{array}{l}\text { Ag........... } \\
\text { Cd.......... } \\
\text { Sn............ } \\
\text { Sh........... } \\
\text { Cs............ }\end{array}$ & $\begin{array}{c}(.5) \\
(.12) \\
(.95) \\
.51 \\
(1.7)\end{array}$ & $\begin{array}{l}(.24) \\
(.11) \\
(.32) \\
(.18) \\
.195\end{array}$ & $\begin{array}{c}(.6) \\
(.7) \\
(.71) \\
.84 \\
(1.1)\end{array}$ & $\begin{array}{l}(.3) \\
(.08) \\
(.552) \\
(.22) \\
.75\end{array}$ & $\begin{array}{l}(.23) \\
(.08) \\
(.371) \\
(.4) \\
.24\end{array}$ & $\begin{array}{l}(.15) \\
(.07) \\
(.17) \\
(.10) \\
.14\end{array}$ & $\begin{array}{c}(1.2) \\
(.07) \\
(1.75) \\
.54 \\
(2.1)\end{array}$ & $\begin{array}{l}(.15) \\
(.043) \\
(.4) \\
.15 \\
(.09)\end{array}$ & $\begin{array}{l}1 \\
2 \\
1 \\
2 \\
2\end{array}$ & \\
\hline Ba ............ & (56) & 300 & (83) & $(40)$ & 200 & 35 & $(120)$ & $(500)$ & 4 & $\begin{array}{c}\text { ICAP-AES [2f,5f]; } \\
\text { EDXRF [6n] }\end{array}$ \\
\hline La............. & (9) & $(4.7)$ & 6.0 & (5.1) & $(6.2)$ & $(2.9)$ & (19) & $(2.5)$ & 3 & $\begin{array}{l}\text { EDXRF }[2 n, 3 n, 5 f, \\
6 n, 8 n]\end{array}$ \\
\hline $\begin{array}{l}\mathrm{Ce} . \ldots . \ldots . . . . \\
\mathrm{Pr} \ldots . . . . . . . . \\
\text { Nd............ }\end{array}$ & $\begin{array}{l}17 \\
(1.9) \\
7.7\end{array}$ & $\begin{array}{l}(8) \\
(.93) \\
(3.4)\end{array}$ & $\begin{array}{l}(11) \\
(1.4) \\
(4.9)\end{array}$ & $\begin{array}{l}(10) \\
(1.12) \\
(4.3)\end{array}$ & $\begin{array}{l}(11) \\
(1.31) \\
(5.0)\end{array}$ & $\begin{array}{l}4.7 \\
(.55) \\
(2.1)\end{array}$ & $\begin{array}{l}(34) \\
(4.1) \\
(14)\end{array}$ & $\begin{array}{l}4.3 \\
(.43) \\
(1.8)\end{array}$ & $\begin{array}{l}3 \\
1 \\
2\end{array}$ & $\begin{array}{l}\text { EDXRF [6n,8n] } \\
\text { INAA [2-5n] }\end{array}$ \\
\hline $\begin{array}{l}\text { Sm .......... } \\
\text { Eu .......... } \\
\text { Tb .......... } \\
\text { Yb.......... } \\
\text { Hf........... }\end{array}$ & $\begin{array}{l}(1.8) \\
.37 \\
.248 \\
.85 \\
(.8)\end{array}$ & $\begin{array}{l}(.8) \\
(.18) \\
.11 \\
(.40) \\
.64\end{array}$ & $\begin{array}{r}(1.1) \\
.21 \\
.14 \\
.52 \\
(.7)\end{array}$ & $\begin{array}{l}(1.0) \\
(.19) \\
.12 \\
.450 \\
(.56)\end{array}$ & $\begin{array}{l}(1.1) \\
.22 \\
.165 \\
.56 \\
(.50)\end{array}$ & $\begin{array}{l}(.44) \\
.092 \\
.056 \\
.20 \\
.52\end{array}$ & $\begin{array}{l}(3.2) \\
.64 \\
.398 \\
1.6 \\
(2.1)\end{array}$ & $\begin{array}{l}(.33) \\
(.07) \\
(.055) \\
(.26) \\
(.38)\end{array}$ & $\begin{array}{l}2 \\
2 \\
2 \\
2 \\
2\end{array}$ & \\
\hline $\begin{array}{l}\text { Ta........... } \\
\text { W............ } \\
\text { Pb............ } \\
\text { Bi........... } \\
\text { Th ........... }\end{array}$ & $\begin{array}{l}.21 \\
(1.2) \\
7.5 \\
(.117) \\
(2.5)\end{array}$ & $\begin{array}{c}(.12) \\
(.42) \\
(2.3) \\
(.053) \\
(1.6)\end{array}$ & $\begin{array}{l}.18 \\
(1.73) \\
(7) \\
(.088) \\
2.1\end{array}$ & $\begin{array}{c}(.15) \\
.82 \\
(3.4) \\
(.117) \\
1.5\end{array}$ & $\begin{array}{l}.12 \\
(1.0) \\
(2.1) \\
(.051) \\
1.16\end{array}$ & $\begin{array}{l}(.052) \\
.45 \\
1.52 \\
(.035) \\
.60\end{array}$ & $\begin{array}{c}.63 \\
(1.7) \\
12.1 \\
(.23) \\
6.4\end{array}$ & $\begin{array}{l}(.093) \\
(.36) \\
(1.5) \\
- \\
(1.1)\end{array}$ & $\begin{array}{l}2 \\
2 \\
2 \\
1 \\
2\end{array}$ & $\begin{array}{l}\text { ICAP-MS* [8n] } \\
\text { ICAP-MS* [8n] } \\
\text { ICAP-AES [8s] }\end{array}$ \\
\hline U.............. & $(1.0)$ & .58 & (5) & $(.5)$ & $(.57)$ & .79 & (1.9) & .46 & 2 & \\
\hline
\end{tabular}


in tables 5 and 6 . Values excluded from the determination of recommended values and the reason for exclusion are given in the final column of tables 5 and 6 . After the analyses were completed, 43 percent of the values reported in tables 5 and 6 were recommended values.

\section{CONCLUSIONS}

A multitechnique approach is the best method to differentiate "good" values from "poor" values. Differences are caused by spectral interferences, volatilization due to ashing, or incomplete sample dissolution. Interferences for a given element usually differ for each technique. Losses caused by volatilization can be determined by comparing data from whole-coal procedures and ash procedures. Insolubility problems can be identified by comparing data from techniques not requiring dissolution with data from techniques requiring dissolution.

This paper does not recommend values for all elements, but it does provide reliable data for many trace elements. It provides manipulations of the data that will allow readers to make their own interpretations and judgments. It also demonstrates that some techniques are more reliable than others for individual elements, and they depend on the concentration of an element. This paper shows that the more high-precision tests that can be run on a sample to measure certain elements, the greater the reliability the data and the greater the likelihood of determining a recommended value. More important, it points out the uncertainties in attempting to obtain reliable data from a single technique for coals of widely differing types, it provides a basis for determining some uncertainties of the techniques, and it should aid in the evaluation of data determined by different techniques.

\section{REFERENCES}

American Society for Testing and Materials (ASTM), 1996, ASTM Designation D 3174-93, Standard test method for ash in the analysis sample of coal and coke from coal: 1996 Annual Book of ASTM Standards, v. 05.05, Gaseous fuels; Coal and coke, p. 291-294.

Finkelman, R.B., Palmer, C.A., Krasnow, M.R., Aruscavage, P.J., Sellers, G.A., and Dulong, F.T., 1990, Combustion and leaching behavior of elements in the Argonne Premium Coal samples: Energy and Fuels, v. 4, no. 6, p. 755-767.

Kane, J.S., Arbogast, B.F., and Leventhal, J.S., 1990, Characterization of Devonian Ohio Shale SDO-1 and a geochemical reference sample: Geostandards Newsletter, v. 14, p. 169-196.

Taylor, J.K., 1987, Quality assurance of chemical measurements: Chelsea, Mich., Lewis Publishers, Inc., 328 p.

Vorres, K.S., 1990, The Argonne Premium Coal Sample Program: Energy and Fuels, v. 4, no. 5, p. 420-426.

1993, Users handbook for the Argonne Premium Coal Sample Program: Argonne National Laboratories Report ANL/PCSP-93/1, 200 p. 


\section{Appendix 1. Comparison of the concentrations of 51 elements determined by multiple analytical techniques in 8 Argonne Premium Coal samples.}

Techniques. - The techniques include inductively coupled argon plasma-atomic emission spectrometry (ICAP-AES) used in both Denver (D) and Reston (R) labs, inductively coupled argon plasma-mass spectrometry (ICAP-MS), flame (FAAS) and graphite furnace (GFAAS) atomic absorption spectrometry, hydride-generation atomic absorption spectrometry (HGAAS), direct-current arc atomic emission spectrography (DCAES), wavelength-dispersive (WDXRF) and energy-dispersive (EDXRF) X-ray fluorescence spectrometry, and instrumental neutron activation analysis (INAA).

Material analyzed.-Whole coal (WC) and ash were analyzed. Concentrations originally reported on an ash basis were converted to a whole-coal basis, and concentrations originally reported as an oxide were converted to an elemental basis for ease of comparison. The ash yield was also reported.

Location.-Materials were analyzed in U.S. Geological Survey laboratories in Denver (D), Colo., and Reston (R), Va.

Concentrations. - The concentrations are reported as weight percent and parts per million (ppm), which is equivalent to micrograms per gram.

Type styles and parentheses.-Average values in parentheses indicate that only one value was reported. Techniques in bold type are high-precision techniques; concentrations (except outliers) determined by these techniques are also in bold type. Techniques in regular type are less precise than those in bold; concentrations determined by the lowprecision techniques are also in regular type.

Outliers. - Concentrations in braces are considered outliers for the statistical analysis used to determine the recommended values or the best average (see table 6 and appendix 2). Single outliers were determined by the Grubbs test (J.K. Taylor, 1987, Quality assurance of chemical measurements, Chelsea, Mich., Lewis Publishers, Inc., 328 p.). Multiple outliers for a given sample technique were determined by the 40 percent rule (see paper by Palmer and Klizas, this volume). Values with one significant figure were treated as outliers. 
Appendix 1. Comparison of the concentrations of 51 elements determined by multiple analytical techniques in 8 Argonne Premium Coal samples-Continued.

[Analyses of splits for each sample are followed by an average. -, no data. See definitions on p. 77]

\begin{tabular}{|c|c|c|c|c|c|c|c|c|c|c|}
\hline \multirow[b]{2}{*}{ 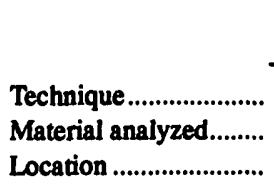 } & \multirow{2}{*}{$\begin{array}{c}\text { Ash (\%) } \\
550^{\circ} \mathrm{C} \\
\text { WC } \\
\text { R }\end{array}$} & \multicolumn{4}{|c|}{ Si (weight percent) } & \multicolumn{5}{|c|}{ Al (weight percent) } \\
\hline & & $\begin{array}{c}\text { ICAP-AES } \\
\text { Ash } \\
\text { D }\end{array}$ & $\begin{array}{c}\text { WDXRF } \\
\text { Ash } \\
\text { R }\end{array}$ & $\begin{array}{c}\text { DCAES } \\
\text { Ash } \\
\mathbf{R}\end{array}$ & $\begin{array}{c}\text { DCAES } \\
\text { WC } \\
\mathbf{R}\end{array}$ & $\begin{array}{c}\text { WDXRF } \\
\text { Ash } \\
\text { R }\end{array}$ & $\begin{array}{l}\text { ICAP-AES } \\
\text { Ash } \\
\mathbf{R}\end{array}$ & $\begin{array}{c}\text { ICAP-AES } \\
\text { Ash } \\
\text { D }\end{array}$ & $\begin{array}{c}\text { DCAES } \\
\text { Ash } \\
\text { R }\end{array}$ & $\begin{array}{l}\text { DCAES } \\
\text { WC } \\
\mathbf{R}\end{array}$ \\
\hline $\begin{array}{l}\text { UF PC-1-1........... } \\
\text { UF PC-1-2................ } \\
\text { UF PC-1-3............. } \\
\text { AVG PC-1 }\end{array}$ & $\begin{array}{l}13.5 \\
13.5 \\
13.5 \\
13.5\end{array}$ & $\begin{array}{l}\mathbf{2 . 5} \\
2.6 \\
\mathbf{2 . 7} \\
\mathbf{2 . 6}\end{array}$ & $\begin{array}{r}2.64 \\
2.69 \\
2 . \overline{2.67}\end{array}$ & $\begin{array}{l}3.0 \\
3.0 \\
3.4 \\
3.1\end{array}$ & $\begin{array}{l}3 \\
4 \\
3 \\
3\end{array}$ & $\begin{array}{c}1.54 \\
1.54 \\
1 . \overline{54}\end{array}$ & $\begin{array}{l}1.61 \\
1.61 \\
1.59 \\
1.60\end{array}$ & $\begin{array}{l}1.5 \\
1.5 \\
1.6 \\
1.6\end{array}$ & $\begin{array}{l}2.0 \\
2.6 \\
2.6 \\
2.4\end{array}$ & $\begin{array}{l}2 \\
2 \\
2 \\
2\end{array}$ \\
\hline $\begin{array}{l}\text { WY PC-2-1 } \\
\text { WY PC-2-2 } \\
\text { WY PC-2-3 } \\
\text { AVG PC-2 }\end{array}$ & $\begin{array}{l}8.5 \\
8.5 \\
8.5 \\
8.5\end{array}$ & $\begin{array}{l}99 \\
1.0 \\
1.1 \\
1.0\end{array}$ & $\begin{array}{l}1.23 \\
1.25 \\
1 . \overline{24}\end{array}$ & $\begin{array}{l}1.3 \\
1.3 \\
1.5 \\
1.4\end{array}$ & $\begin{array}{r}.80 \\
1.00 \\
.52 \\
.77\end{array}$ & $\begin{array}{l}.675 \\
.670 \\
\overline{.672}\end{array}$ & $\begin{array}{l}.695 \\
.698 \\
.705 \\
.699\end{array}$ & $\begin{array}{l}.63 \\
.63 \\
.72 \\
.66\end{array}$ & $\begin{array}{l}.42 \\
.54 \\
.61 \\
.53\end{array}$ & $\begin{array}{l}.47 \\
.54 \\
.44 \\
.48\end{array}$ \\
\hline 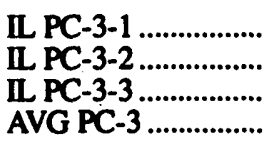 & $\begin{array}{l}16.2 \\
16.2 \\
16.2 \\
16.2\end{array}$ & $\begin{array}{c}3.1 \\
3.0 \\
\{2.7\} \\
2.9\end{array}$ & $\begin{array}{c}3.04 \\
3.04 \\
\overline{3.04}\end{array}$ & $\begin{array}{l}3.6 \\
3.2 \\
4.0 \\
3.6\end{array}$ & $\begin{array}{l}3 \\
4 \\
3 \\
3\end{array}$ & $\begin{array}{c}1.21 \\
1.20 \\
1.21\end{array}$ & $\begin{array}{l}1.26 \\
1.25 \\
1.25 \\
1.25\end{array}$ & $\begin{array}{l}\{1.4\} \\
1.3 \\
1.2 \\
1.3\end{array}$ & $\begin{array}{l}1.9 \\
1.9 \\
2.1 \\
2.0\end{array}$ & $\begin{array}{l}2 \\
2 \\
2 \\
2\end{array}$ \\
\hline $\begin{array}{l}\text { PITT PC-41 } \\
\text { PITT PC-4-2 } \\
\text { PITT PC-4............. } \\
\text { AVG PC-4 }\end{array}$ & $\begin{array}{l}9.2 \\
9.2 \\
9.2 \\
9.2\end{array}$ & $\begin{array}{l}1.8 \\
1.8 \\
1.8 \\
1.8\end{array}$ & $\begin{array}{l}1.95 \\
1.97 \\
\overline{1.96}\end{array}$ & $\begin{array}{l}2.4 \\
2.7 \\
2.9 \\
2.7\end{array}$ & $\begin{array}{l}2 \\
3 \\
2 \\
2\end{array}$ & $\begin{array}{l}.988 \\
.974 \\
\overline{.981}\end{array}$ & $\begin{array}{l}.994 \\
1.00 \\
.994 \\
.997\end{array}$ & $\begin{array}{l}.97 \\
.97 \\
\{.92\} \\
.96\end{array}$ & $\begin{array}{l}2.2 \\
1.9 \\
2.2 \\
2.1\end{array}$ & $\begin{array}{l}1 \\
2 \\
2 \\
2\end{array}$ \\
\hline $\begin{array}{l}\text { POC PC-5-1 } \\
\text { POC PC-5-2 } \ldots \ldots \ldots \ldots \\
\text { POC PC-5-3 } \\
\text { AVG PC-5 } \ldots \ldots \ldots \ldots \\
\end{array}$ & $\begin{array}{l}5.3 \\
5.3 \\
5.3 \\
5.3\end{array}$ & $\begin{array}{l}0.77 \\
0.75 \\
0.72 \\
0.75\end{array}$ & $\begin{array}{l}.810 \\
.798 \\
\overline{.804}\end{array}$ & $\begin{array}{r}.95 \\
.90 \\
1.00 \\
.95\end{array}$ & $\begin{array}{r}.83 \\
1.00 \\
.80 \\
.88\end{array}$ & $\begin{array}{l}.550 \\
.547 \\
\overline{.548}\end{array}$ & $\begin{array}{l}\mathbf{5 5 1} \\
\mathbf{. 5 5 1} \\
\mathbf{5 4 6} \\
.549\end{array}$ & $\begin{array}{l}\{.59\} \\
.56 \\
.56 \\
.57\end{array}$ & $\begin{array}{l}.64 \\
.74 \\
.74 \\
.71\end{array}$ & $\begin{array}{l}.80 \\
.92 \\
.84 \\
.85\end{array}$ \\
\hline 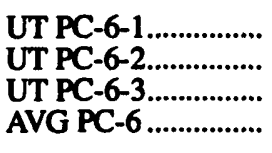 & $\frac{4.6}{(4.6)}$ & $\begin{array}{l}.88 \\
.92 \\
.94 \\
.91\end{array}$ & $\begin{array}{l}.893 \\
\overline{(.893)}\end{array}$ & $\begin{array}{l}.74 \\
.92 \\
.92 \\
.86\end{array}$ & $\bar{z}$ & $\frac{.370}{\overline{(.370)}}$ & $\begin{array}{l}.348 \\
.345 \\
.347\end{array}$ & $\begin{array}{l}.36 \\
.39 \\
.39 \\
.38\end{array}$ & $\begin{array}{l}.31 \\
.32 \\
.29 \\
.32\end{array}$ & $\begin{array}{l}- \\
-\end{array}$ \\
\hline $\begin{array}{l}\text { WV PC-7-1 } \\
\text { WV PC-7-2 ................. } \\
\text { WV PC-7-3 .............. } \\
\text { AVG PC-7 }\end{array}$ & $\frac{19.4}{\overline{(19.4)}}$ & $\begin{array}{l}4.8 \\
5.3 \\
5.0 \\
5.0\end{array}$ & $\frac{4.90}{(4.90)}$ & $\begin{array}{l}4.3 \\
5.8 \\
5.4 \\
5.2\end{array}$ & $\frac{-}{-}$ & $\frac{3.17}{\overline{-}}$ & $\begin{array}{l}3.12 \\
3.18 \\
3.16 \\
3.15\end{array}$ & $\begin{array}{l}3.1 \\
3.2 \\
3.2 \\
3.2\end{array}$ & $\begin{array}{l}3.3 \\
4.3 \\
4.1 \\
3.9\end{array}$ & $\begin{array}{l}- \\
- \\
-\end{array}$ \\
\hline 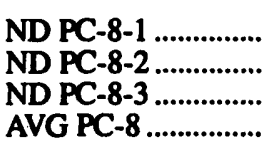 & $\frac{9.5}{\overline{(9.5)}}$ & $\begin{array}{l}.67 \\
.67 \\
.67 \\
.67\end{array}$ & $\begin{array}{l}\{.768\} \\
\overline{-} \\
(0.768)\end{array}$ & $\begin{array}{l}.54 \\
.63 \\
.63 \\
.60\end{array}$ & $\underline{-}$ & $\frac{\{.45\}}{-}$ & $\begin{array}{l}.396 \\
.400 \\
.404 \\
.400\end{array}$ & $\begin{array}{l}.40 \\
.40 \\
.40 \\
.40\end{array}$ & $\begin{array}{l}.21 \\
.28 \\
.21 \\
.23\end{array}$ & $\frac{z}{-}$ \\
\hline
\end{tabular}


Appendix 1. Comparison of the concentrations of 51 elements determined by multiple analytical techniques in 8 Argonne Premium Coal samples-Continued.

[Analyses of splits for each sample are followed by an average. -, no data. See definitions on p. 77]

\begin{tabular}{|c|c|c|c|c|c|c|c|c|c|c|c|}
\hline \multirow[b]{2}{*}{$\begin{array}{l}\text { Technique ..................... } \\
\text { Material analyzed.......... } \\
\text { Location .......................... }\end{array}$} & \multicolumn{6}{|c|}{ Fe (weight percent) } & \multicolumn{5}{|c|}{ Mg (weight percent) } \\
\hline & $\begin{array}{c}\text { WNAA } \\
\mathbf{W C} \\
\mathbf{R}\end{array}$ & $\begin{array}{c}\text { WDXRF } \\
\text { Ash } \\
\mathbf{R}\end{array}$ & $\begin{array}{c}\text { ICAP-AES } \\
\text { Ash } \\
\mathbf{R}\end{array}$ & $\begin{array}{c}\text { ICAP-AES } \\
\text { Ash } \\
\text { D }\end{array}$ & $\begin{array}{c}\text { DCAES } \\
\text { Ash } \\
\text { R }\end{array}$ & $\begin{array}{c}\text { DCAES } \\
\text { WC } \\
\mathbf{R}\end{array}$ & $\begin{array}{c}\text { WDXRF } \\
\text { Ash } \\
\text { R }\end{array}$ & $\begin{array}{c}\text { ICAP-AES } \\
\text { Ash } \\
\mathbf{R}\end{array}$ & $\begin{array}{c}\text { ICAP-AES } \\
\text { Ash } \\
\text { D }\end{array}$ & $\begin{array}{c}\text { DCAES } \\
\text { Ash } \\
\mathbf{R}\end{array}$ & $\begin{array}{c}\text { DCAES } \\
\text { WC } \\
\text { R }\end{array}$ \\
\hline $\begin{array}{l}\text { UF PC-1-1 } \\
\text { UF PC-1-2 } \\
\text { UF PC-1 } 1 \ldots \ldots \ldots \ldots \ldots \ldots \\
\text { AVG PC-1 } \ldots \ldots \ldots \ldots \ldots \ldots \ldots \\
\end{array}$ & $\begin{array}{l}1.76 \\
1.81 \\
1.79 \\
1.78\end{array}$ & $\begin{array}{c}1.98 \\
1.88 \\
\overline{1.93}\end{array}$ & $\begin{array}{l}1.86 \\
1.89 \\
1.84 \\
1.86\end{array}$ & $\begin{array}{l}1.6 \\
1.7 \\
1.7 \\
1.7\end{array}$ & $\begin{array}{l}1.6 \\
1.3 \\
1.7 \\
1.6\end{array}$ & $\begin{array}{l}2 \\
3 \\
2 \\
2\end{array}$ & $\begin{array}{r}0.079 \\
.079 \\
\overline{.079}\end{array}$ & $\begin{array}{r}0.082 \\
.082 \\
.081 \\
.082\end{array}$ & $\begin{array}{r}0.075 \\
.078 \\
.080 \\
.078\end{array}$ & $\begin{array}{r}0.13 \\
.15 \\
.16 \\
.15\end{array}$ & $\begin{array}{r}0.097 \\
.100 \\
.100 \\
.099\end{array}$ \\
\hline 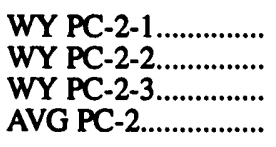 & $\begin{array}{l}.381 \\
.379 \\
.339 \\
.366\end{array}$ & $\begin{array}{l}.33 \\
.32 \\
.33\end{array}$ & $\begin{array}{l}\mathbf{3 5 8} \\
\mathbf{3 7 9} \\
\mathbf{3 6 3} \\
\mathbf{3 6 7}\end{array}$ & $\begin{array}{l}.31 \\
.35 \\
.35 \\
.34\end{array}$ & $\begin{array}{l}.26 \\
.26 \\
.31 \\
.27\end{array}$ & $\begin{array}{l}.34 \\
.33 \\
.20 \\
.29\end{array}$ & $\begin{array}{l}.25 \\
.27 \\
\overline{.26}\end{array}$ & $\begin{array}{l}.241 \\
.236 \\
\overline{.239}\end{array}$ & $\begin{array}{l}.20 \\
.20 \\
.23 \\
.21\end{array}$ & $\begin{array}{l}.33 \\
.39 \\
.37 \\
.37\end{array}$ & $\begin{array}{l}.20 \\
.20 \\
.20 \\
.20\end{array}$ \\
\hline 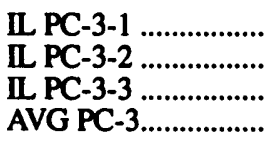 & $\begin{array}{l}2.66 \\
2.67 \\
2.68 \\
2.67\end{array}$ & $\begin{array}{l}2.71 \\
2.70 \\
\overline{2.70}\end{array}$ & $\begin{array}{l}2.72 \\
2.66 \\
2.79 \\
2.72\end{array}$ & $\begin{array}{l}2.4 \\
2.5 \\
2.3 \\
2.4\end{array}$ & $\begin{array}{l}2.3 \\
2.3 \\
2.6 \\
2.4\end{array}$ & $\begin{array}{l}2 \\
2 \\
3 \\
2\end{array}$ & $\begin{array}{c}\{.09\} \\
\{.09\} \\
\frac{.09}{.09}\end{array}$ & $\begin{array}{l}.076 \\
.078 \\
.076 \\
.077\end{array}$ & $\begin{array}{l}.078 \\
.075 \\
.068 \\
.073\end{array}$ & $\begin{array}{l}.11 \\
.11 \\
.12 \\
.12\end{array}$ & $\begin{array}{l}.096 \\
.099 \\
.100 \\
.098\end{array}$ \\
\hline $\begin{array}{l}\text { PITT PC-4 } 1 \ldots \ldots \ldots \\
\text { PITT PC-4-2 } \\
\text { PITT PC-4............ } \\
\text { AVG PC-4................. }\end{array}$ & $\begin{array}{l}1.36 \\
1.34 \\
1.33 \\
1.35\end{array}$ & $\begin{array}{l}1.45 \\
1.43 \\
1.44\end{array}$ & $\begin{array}{l}1.34 \\
1.32 \\
1.31 \\
1.32\end{array}$ & $\begin{array}{l}1.2 \\
1.2 \\
1.3 \\
1.2\end{array}$ & $\begin{array}{l}1.7 \\
1.8 \\
2.0 \\
1.9\end{array}$ & $\begin{array}{l}1 \\
1 \\
2 \\
1\end{array}$ & $\begin{array}{c}\{.04\} \\
\{.03\} \\
\frac{.03}{6}\end{array}$ & $\begin{array}{l}.038 \\
.038 \\
.038 \\
.038\end{array}$ & $\begin{array}{l}.033 \\
.033 \\
.033 \\
.033\end{array}$ & $\begin{array}{l}.065 \\
.064 \\
.089 \\
.073\end{array}$ & $\begin{array}{l}.045 \\
.048 \\
.052 \\
.048\end{array}$ \\
\hline $\begin{array}{l}\text { POC PC-5-1 } \\
\text { POC PC-5-2 } \ldots \ldots \ldots \ldots . . . . . . \\
\text { POC PC-5-3 ............ } \\
\text { AVG PC-5 } \ldots \ldots \ldots \ldots \ldots . . .\end{array}$ & $\begin{array}{l}.504 \\
.521 \\
.502 \\
.509\end{array}$ & $\begin{array}{l}\mathbf{5 1 9} \\
\mathbf{5 2 2} \\
\overline{\mathbf{5 2 1}}\end{array}$ & $\begin{array}{l}.513 \\
.505 \\
.504 \\
.507\end{array}$ & $\begin{array}{l}.52 \\
.48 \\
.48 \\
.50\end{array}$ & $\begin{array}{l}.52 \\
.44 \\
.53 \\
.50\end{array}$ & $\begin{array}{l}.60 \\
.80 \\
.68 \\
.69\end{array}$ & $\begin{array}{l}.067 \\
.067 \\
\overline{.067}\end{array}$ & $\begin{array}{l}.0562 \\
.0551 \\
.551 \\
.0548\end{array}$ & $\begin{array}{l}.0575 \\
.0543 \\
.0543 \\
.0554\end{array}$ & $\begin{array}{l}.10 \\
.11 \\
.11 \\
.11\end{array}$ & $\begin{array}{l}.079 \\
.074 \\
.079 \\
.077\end{array}$ \\
\hline 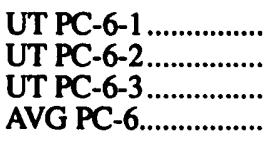 & $\begin{array}{l}\mathbf{3 2 7} \\
\mathbf{3 1 0} \\
\mathbf{3 1 5} \\
\mathbf{3 1 7}\end{array}$ & $\frac{.29}{(\overline{29})}$ & $\begin{array}{l}.284 \\
.281 \\
.282\end{array}$ & $\begin{array}{l}.29 \\
.29 \\
.31 \\
.30\end{array}$ & $\begin{array}{l}.21 \\
.27 \\
.23 \\
.24\end{array}$ & $\begin{array}{l}- \\
-\end{array}$ & $\frac{.048}{-}$ & $\begin{array}{l}.030 \\
.030 \\
\overline{.030}\end{array}$ & $\begin{array}{l}.028 \\
.031 \\
.031 \\
.030\end{array}$ & $\begin{array}{l}.043 \\
.038 \\
.041 \\
.041\end{array}$ & $\begin{array}{l}- \\
-\end{array}$ \\
\hline 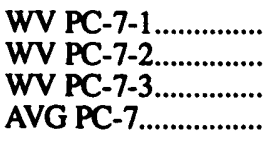 & $\begin{array}{l}.404 \\
.384 \\
.408 \\
.399\end{array}$ & $\frac{37}{(37)}$ & $\begin{array}{l}\mathbf{3 9 6} \\
\mathbf{3 8 1} \\
\mathbf{3 7 9} \\
\mathbf{3 8 5}\end{array}$ & $\begin{array}{l}.41 \\
.39 \\
.38 \\
.39\end{array}$ & $\begin{array}{l}.35 \\
.45 \\
.41 \\
.40\end{array}$ & $\frac{z}{z}$ & $\frac{\{.08\}}{-}$ & $\begin{array}{l}.092 \\
.095 \\
.096 \\
.094\end{array}$ & $\begin{array}{l}.082 \\
.090 \\
.084 \\
.085\end{array}$ & $\begin{array}{l}.128 \\
.084 \\
.078 \\
.097\end{array}$ & $\begin{array}{l}- \\
-\end{array}$ \\
\hline 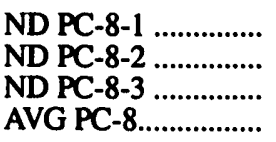 & $\begin{array}{l}\mathbf{5 5 3} \\
\mathbf{5 2 9} \\
\mathbf{5 6 0} \\
\mathbf{5 4 7 7}\end{array}$ & $\frac{.45}{(\overline{45)}}$ & $\begin{array}{l}.466 \\
.470 \\
.480 \\
.472\end{array}$ & $\begin{array}{l}.45 \\
.47 \\
.46 \\
.46\end{array}$ & $\begin{array}{l}.35 \\
.43 \\
.33 \\
.37\end{array}$ & $\frac{-}{-}$ & $\begin{array}{c}.42 \\
- \\
\overline{(.42)}\end{array}$ & $\begin{array}{l}.395 \\
.395 \\
.405 \\
.398\end{array}$ & $\begin{array}{l}.34 \\
.355 \\
.349 \\
.351\end{array}$ & $\begin{array}{l}.52 \\
.51 \\
.51 \\
.51\end{array}$ & - \\
\hline
\end{tabular}


Appendix 1. Comparison of the concentrations of 51 elements determined by multiple analytical techniques in 8 Argonne Premium Coal samples-Continued.

[Analyses of splits for each sample are followed by an average. - , no data. See definitions on p. 77]

\begin{tabular}{|c|c|c|c|c|c|c|c|c|c|c|}
\hline \multirow[b]{2}{*}{$\begin{array}{l}\text { Technique ..................... } \\
\text { Material analyzed........ } \\
\text { Location ......................... }\end{array}$} & \multicolumn{5}{|c|}{$\mathrm{Ca}$ (weight percent) } & \multicolumn{5}{|c|}{$\mathrm{Na}$ (weight percent) } \\
\hline & $\begin{array}{c}\text { WDXRF } \\
\text { Ash } \\
\mathbf{R}\end{array}$ & $\begin{array}{c}\text { ICAP-AES } \\
\text { Ash } \\
\mathbf{R}\end{array}$ & $\begin{array}{c}\text { ICAP-AES } \\
\text { Ash } \\
\text { D }\end{array}$ & $\begin{array}{c}\text { DCAES } \\
\text { Ash } \\
\text { R }\end{array}$ & $\begin{array}{c}\text { DCAES } \\
\text { WC } \\
\text { R }\end{array}$ & $\begin{array}{c}\text { INAA } \\
\text { WC } \\
\mathbf{R}\end{array}$ & $\begin{array}{c}\text { ICAP-AES } \\
\text { Ash } \\
\mathbf{R}\end{array}$ & $\begin{array}{c}\text { ICAP-AES } \\
\text { Ash } \\
\text { D }\end{array}$ & $\begin{array}{l}\text { WDXRF } \\
\text { Ash } \\
\text { R }\end{array}$ & $\begin{array}{l}\text { DCAES } \\
\text { Ash } \\
\text { R }\end{array}$ \\
\hline $\begin{array}{l}\text { UF PC-1-1 } \\
\text { UF PC-1-2............... } \\
\text { UF PC-1-3............ } \\
\text { AVG PC-1 }\end{array}$ & $\begin{array}{r}0.40 \\
.40 \\
.40\end{array}$ & $\begin{array}{r}0.447 \\
.445 \\
.443 \\
.445\end{array}$ & $\begin{array}{r}0.40 \\
.40 \\
.40 \\
.40\end{array}$ & $\begin{array}{r}0.69 \\
.59 \\
.63 \\
.64\end{array}$ & $\begin{array}{r}0.57 \\
.54 \\
.63 \\
.58\end{array}$ & $\begin{array}{r}0.0336 \\
.0343 \\
.0342 \\
.0341\end{array}$ & $\begin{array}{r}0.032 \\
.032 \\
.032 \\
.032\end{array}$ & $\begin{array}{r}0.034 \\
.034 \\
.034 \\
.034\end{array}$ & $\begin{array}{c}\{0.03\} \\
\{.03\} \\
\overline{.03}\end{array}$ & $\begin{array}{r}0.042 \\
.047 \\
.046 \\
.045\end{array}$ \\
\hline $\begin{array}{l}\text { WY PC-2-1 } \\
\text { WY PC-2-2 } \\
\text { WY PC } 2-3 \ldots \ldots \ldots \\
\text { AVG PC-2 } \ldots \ldots \ldots \ldots . . . . . . . . . . \\
\end{array}$ & $\begin{array}{l}1.10 \\
1.15 \\
1 . \overline{12}\end{array}$ & $\begin{array}{l}1.21 \\
1.16 \\
1.22 \\
1.19\end{array}$ & $\begin{array}{l}1.0 \\
.97 \\
1.1 \\
1.0\end{array}$ & $\begin{array}{l}1.0 \\
1.3 \\
1.4 \\
1.2\end{array}$ & $\begin{array}{l}1 \\
1 \\
1 \\
1\end{array}$ & $\begin{array}{l}.114 \\
.117 \\
.113 \\
.115\end{array}$ & $\begin{array}{l}.119 \\
.119 \\
.119 \\
.119\end{array}$ & $\begin{array}{l}.12 \\
.12 \\
.12 \\
.12\end{array}$ & $\begin{array}{l}.10 \\
.083 \\
-092\end{array}$ & $\begin{array}{l}.12 \\
.16 \\
.12 \\
.13\end{array}$ \\
\hline 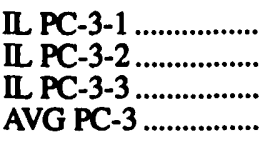 & $\begin{array}{l}.90 \\
.89 \\
\frac{90}{90}\end{array}$ & $\begin{array}{l}.943 \\
965 \\
.972 \\
960\end{array}$ & $\begin{array}{l}96 \\
94 \\
.87 \\
92\end{array}$ & $\begin{array}{l}1.6 \\
1.5 \\
1.8 \\
1.6\end{array}$ & $\begin{array}{l}2 \\
2 \\
1 \\
2\end{array}$ & $\begin{array}{l}.103 \\
.101 \\
.103 \\
.102\end{array}$ & $\begin{array}{l}.097 \\
.099 \\
.094 \\
.097\end{array}$ & $\begin{array}{l}.11 \\
.11 \\
.10 \\
.11\end{array}$ & $\begin{array}{c}.13 \\
\{.09\} \\
(\overline{13})\end{array}$ & $\begin{array}{l}.16 \\
.14 \\
.15 \\
.15\end{array}$ \\
\hline $\begin{array}{l}\text { PITT PC-41 } \\
\text { PITT PC-42 } \\
\text { PITT PC-4-............. } \\
\text { AVG PC-4 }\end{array}$ & $\begin{array}{l}.20 \\
.20 \\
.20\end{array}$ & $\begin{array}{l}.211 \\
.205 \\
.203 \\
.206\end{array}$ & $\begin{array}{l}.18 \\
.18 \\
.19 \\
.19\end{array}$ & $\begin{array}{l}.46 \\
.33 \\
.43 \\
.41\end{array}$ & $\begin{array}{l}.24 \\
.34 \\
.28 \\
.29\end{array}$ & $\begin{array}{l}.0343 \\
.0342 \\
.0344 \\
.0343\end{array}$ & $\begin{array}{l}.032 \\
.032 \\
.031 \\
.032\end{array}$ & $\begin{array}{l}.034 \\
.034 \\
.033 \\
.034\end{array}$ & $\begin{array}{c}\{.04\} \\
\frac{\{.03\}}{.03}\end{array}$ & $\begin{array}{l}.039 \\
.033 \\
.037 \\
.036\end{array}$ \\
\hline 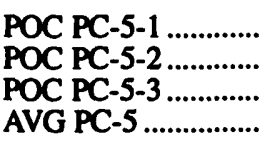 & $\begin{array}{l}.443 \\
.443 \\
.443\end{array}$ & $\begin{array}{l}.464 \\
.452 \\
.452 \\
.456\end{array}$ & $\begin{array}{l}.45 \\
.45 \\
.45 \\
.45\end{array}$ & $\begin{array}{l}.53 \\
.58 \\
.64 \\
.58\end{array}$ & $\begin{array}{l}.69 \\
.93 \\
.79 \\
.80\end{array}$ & $\begin{array}{l}.0797 \\
.0773 \\
.0778 \\
.0782\end{array}$ & $\begin{array}{l}.0832 \\
.0832 \\
.0816 \\
.0826\end{array}$ & $\begin{array}{l}.0826 \\
.0826 \\
.0826 \\
.0826\end{array}$ & $\begin{array}{l}.073 \\
.069 \\
\overline{.071}\end{array}$ & $\begin{array}{l}.13 \\
.13 \\
.13 \\
.13\end{array}$ \\
\hline $\begin{array}{l}\text { UT PC-6-1............ } \\
\text { UT PC-6-2................ } \\
\text { UT PC-6-3............... } \\
\text { AVG PC-6 }\end{array}$ & $\overline{.401}$ & $\begin{array}{l}.418 \\
.401 \\
.409\end{array}$ & $\begin{array}{l}\{.35\} \\
.43 \\
.43 \\
.43\end{array}$ & $\begin{array}{l}.28 \\
.29 \\
.29 \\
.29\end{array}$ & E & $\begin{array}{l}.148 \\
.147 \\
.143 \\
.146\end{array}$ & $\begin{array}{l}.127 \\
.124 \\
.126\end{array}$ & $\begin{array}{l}.13 \\
.13 \\
.13 \\
.13\end{array}$ & $\frac{.13}{(.13)}$ & $\begin{array}{l}.087 \\
.064 \\
.064 \\
.072\end{array}$ \\
\hline 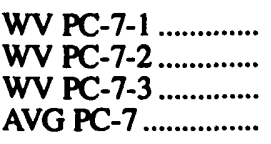 & $\frac{\{.06\}}{(\overline{06})}$ & $\begin{array}{l}.057 \\
.058 \\
.058 \\
.058\end{array}$ & $\begin{array}{l}.056 \\
.061 \\
.058 \\
.058\end{array}$ & $\begin{array}{l}.078 \\
.060 \\
.095 \\
.078\end{array}$ & $\overline{-}$ & $\begin{array}{l}\{.0460\} \\
.0351 \\
.0352 \\
.0388\end{array}$ & $\begin{array}{l}.033 \\
.035 \\
.036 \\
.034\end{array}$ & $\begin{array}{l}.0346 \\
.0346 \\
.0346 \\
.0346\end{array}$ & $\frac{\{.05\}}{\overline{(.05)}}$ & $\begin{array}{l}.037 \\
.035 \\
.037 \\
.036\end{array}$ \\
\hline $\begin{array}{l}\text { ND PC-8-1 } \\
\text { ND PC-8-2 } \\
\text { ND PC-8.................. } \\
\text { AVG PC-8 }\end{array}$ & $\frac{1.54}{-}$ & $\begin{array}{l}1.52 \\
1.53 \\
1.57 \\
1.54\end{array}$ & $\begin{array}{l}1.4 \\
1.4 \\
1.4 \\
1.4\end{array}$ & $\begin{array}{l}1.2 \\
1.3 \\
1.4 \\
1.3\end{array}$ & $\begin{array}{l}- \\
-\end{array}$ & $\begin{array}{l}.540 \\
.533 \\
.515 \\
.529\end{array}$ & $\begin{array}{l}.460 \\
.464 \\
.475 \\
.466\end{array}$ & $\begin{array}{l}.493 \\
.493 \\
.493 \\
.493\end{array}$ & $\frac{.50}{\overline{(.50)}}$ & $\frac{\overline{.25}}{\overline{(.25)}}$ \\
\hline
\end{tabular}


Appendix 1. Comparison of the concentrations of 51 elements determined by multiple analytical techniques in 8 Argonne Premium Coal samples-Continued.

[Analyses of splits for each sample are followed by an average. —, no data. See definitions on p. 77]

\begin{tabular}{|c|c|c|c|c|c|c|c|c|c|c|}
\hline \multirow[b]{2}{*}{$\begin{array}{l}\text { Technique .................... } \\
\text { Material analyzed......... } \\
\text { Location ......................... }\end{array}$} & \multicolumn{5}{|c|}{$\mathbf{K}$ (weight percent) } & \multicolumn{5}{|c|}{ Ti (weight percent) } \\
\hline & $\begin{array}{c}\text { INAA } \\
\text { WC } \\
\mathbf{R}\end{array}$ & $\begin{array}{c}\text { WDXRF } \\
\text { Ash } \\
\text { R }\end{array}$ & $\begin{array}{c}\text { ICAP-AES } \\
\text { Ash } \\
\mathbf{R}\end{array}$ & $\begin{array}{l}\text { ICAP-AES } \\
\text { Ash } \\
\text { D }\end{array}$ & $\begin{array}{c}\text { DCAES } \\
\text { Ash } \\
\mathbf{R}\end{array}$ & $\begin{array}{c}\text { WDXRF } \\
\text { Ash } \\
\text { R }\end{array}$ & $\begin{array}{c}\text { ICAP-AES } \\
\text { Ash } \\
\mathbf{R}\end{array}$ & $\begin{array}{c}\text { ICAP-AES } \\
\text { Ash } \\
\text { D }\end{array}$ & $\begin{array}{c}\text { DCAES } \\
\text { Ash } \\
\text { R }\end{array}$ & $\begin{array}{l}\text { DCAES } \\
\text { WC } \\
\mathbf{R}\end{array}$ \\
\hline 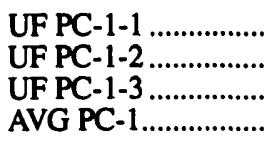 & $\begin{array}{r}0.264 \\
.262 \\
.280 \\
.269\end{array}$ & $\begin{array}{r}0.26 \\
.28 \\
-27\end{array}$ & $\begin{array}{r}0.283 \\
.283 \\
.283 \\
.283\end{array}$ & $\begin{array}{r}0.28 \\
.30 \\
.29 \\
.29\end{array}$ & $\begin{array}{r}0.31 \\
.28 \\
.30 \\
.30\end{array}$ & $\begin{array}{l}.078 \\
.082 \\
.080\end{array}$ & $\begin{array}{r}0.078 \\
.080 \\
.078 \\
.079\end{array}$ & $\begin{array}{r}0.072 \\
.074 \\
.078 \\
.075\end{array}$ & $\begin{array}{r}0.061 \\
.039 \\
.059 \\
.053\end{array}$ & $\begin{array}{r}0.10 \\
.10 \\
.10 \\
.10\end{array}$ \\
\hline 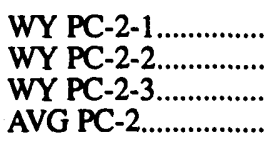 & $\begin{array}{l}.0268 \\
.0335 \\
.0272 \\
.0292\end{array}$ & $\begin{array}{c}\{.03\} \\
\{.03\} \\
.03\end{array}$ & $\begin{array}{l}.028 \\
.028 \\
.026 \\
.028\end{array}$ & $\begin{array}{l}.027 \\
.035 \\
.038 \\
.033\end{array}$ & $\begin{array}{l}.031 \\
.037 \\
.031 \\
.033\end{array}$ & $\begin{array}{l}.051 \\
.052 \\
\overline{.051}\end{array}$ & $\begin{array}{l}.056 \\
.056 \\
.055 \\
.056\end{array}$ & $\begin{array}{l}.048 \\
.049 \\
.056 \\
.051\end{array}$ & $\begin{array}{l}.030 \\
.037 \\
.041 \\
.036\end{array}$ & $\begin{array}{l}.050 \\
.050 \\
.038 \\
.044\end{array}$ \\
\hline 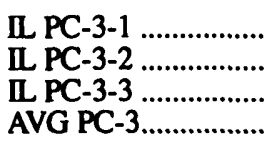 & $\begin{array}{l}.199 \\
.186 \\
.199 \\
.195\end{array}$ & $\begin{array}{l}.21 \\
.20 \\
.20\end{array}$ & $\begin{array}{l}.194 \\
.194 \\
.194 \\
.194\end{array}$ & $\begin{array}{l}.23 \\
.22 \\
.22 \\
.22\end{array}$ & $\begin{array}{l}.24 \\
.26 \\
.28 \\
.26\end{array}$ & $\begin{array}{c}\{.07\} \\
\{.07\} \\
\overline{.07}\end{array}$ & $\begin{array}{l}.070 \\
.070 \\
.070 \\
.070\end{array}$ & $\begin{array}{l}.072 \\
.071 \\
.064 \\
.069\end{array}$ & $\begin{array}{l}.062 \\
.065 \\
.073 \\
.066\end{array}$ & $\begin{array}{l}.089 \\
.100 \\
.086 \\
.092\end{array}$ \\
\hline 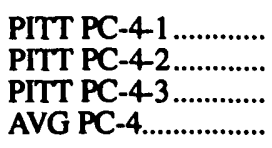 & $\begin{array}{l}.109 \\
.112 \\
.109 \\
.110\end{array}$ & $\begin{array}{l}.11 \\
.11 \\
.11\end{array}$ & $\begin{array}{l}.110 \\
.110 \\
.110 \\
.110\end{array}$ & $\begin{array}{l}.11 \\
.11 \\
.11 \\
.11\end{array}$ & $\begin{array}{l}.13 \\
.12 \\
.14 \\
.13\end{array}$ & $\begin{array}{l}.059 \\
.060 \\
-059\end{array}$ & $\begin{array}{l}.057 \\
.056 \\
.055 \\
.056\end{array}$ & $\begin{array}{l}.051 \\
.051 \\
.049 \\
.050\end{array}$ & $\begin{array}{l}.059 \\
.052 \\
.059 \\
.057\end{array}$ & $\begin{array}{l}.086 \\
.090 \\
.097 \\
.091\end{array}$ \\
\hline 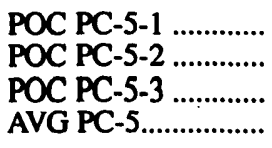 & $\begin{array}{l}.0284 \\
.026 \\
.033 \\
.029\end{array}$ & $\begin{array}{c}\{.03\} \\
\frac{.03}{.03}\end{array}$ & $\begin{array}{l}.027 \\
.028 \\
.028 \\
.028\end{array}$ & $\begin{array}{l}.036 \\
.036 \\
.032 \\
.035\end{array}$ & $\begin{array}{l}.034 \\
.033 \\
.039 \\
.036\end{array}$ & $\begin{array}{l}.040 \\
.039 \\
-.040\end{array}$ & $\begin{array}{l}.038 \\
.038 \\
.037 \\
.038\end{array}$ & $\begin{array}{l}.044 \\
.038 \\
.038 \\
.040\end{array}$ & $\begin{array}{l}.028 \\
.025 \\
.031 \\
.028\end{array}$ & $\begin{array}{l}.084 \\
.084 \\
.078 \\
.082\end{array}$ \\
\hline 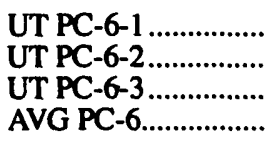 & $\begin{array}{c}.018 \\
<.025 \\
.0252 \\
.022\end{array}$ & $\frac{\{.02\}}{(\overline{.02})}$ & $\begin{array}{c}\{.014\} \\
.014\} \\
.014\end{array}$ & $\begin{array}{l}.027 \\
.027 \\
.029 \\
.028\end{array}$ & $\begin{array}{l}.022 \\
.014 \\
.017 \\
.017\end{array}$ & $\frac{\{.02\}}{(\overline{.02})}$ & $\begin{array}{r}.023 \\
0.023 \\
.023\end{array}$ & $\begin{array}{l}.023 \\
.023 \\
.023 \\
.023\end{array}$ & $\begin{array}{l}.018 \\
.020 \\
.018 \\
.019\end{array}$ & $\overline{-}$ \\
\hline 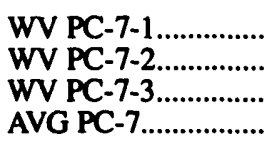 & $\begin{array}{l}.517 \\
.497 \\
.500 \\
.505\end{array}$ & $\frac{.46}{-}$ & $\begin{array}{l}.489 \\
.501 \\
.495 \\
.495\end{array}$ & $\begin{array}{l}.46 \\
53 \\
.48 \\
.49\end{array}$ & $\begin{array}{l}.39 \\
.33 \\
.35 \\
.36\end{array}$ & $\frac{.24}{(\overline{24})}$ & $\begin{array}{l}.260 \\
.260 \\
.260 \\
.260\end{array}$ & $\begin{array}{l}.22 \\
.24 \\
.23 \\
.23\end{array}$ & $\begin{array}{l}.18 \\
.18 \\
.17 \\
.18\end{array}$ & - \\
\hline 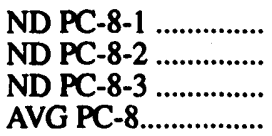 & $\begin{array}{r}.028 \\
<.040 \\
.030 \\
.029\end{array}$ & $\frac{\{.03\}}{(.03)}$ & $\begin{array}{l}\{.012\} \\
\{.016\} \\
\{.015\} \\
\{.014\}\end{array}$ & $\begin{array}{l}.044 \\
.032 \\
.036 \\
.037\end{array}$ & $\begin{array}{l}.038 \\
.033 \\
.039 \\
.037\end{array}$ & $\frac{\{.02\}}{(\overline{.02})}$ & $\begin{array}{l}.020 \\
.019 \\
.020 \\
.020\end{array}$ & $\begin{array}{l}.018 \\
.018 \\
.020 \\
.019\end{array}$ & $\begin{array}{l}.017 \\
.017 \\
.019 \\
.018\end{array}$ & $\overline{-}$ \\
\hline
\end{tabular}


Appendix 1. Comparison of the concentrations of 51 elements determined by multiple analytical techniques in 8 Argonne Premium Coal samples-Continued.

[Analyses of splits for each sample are followed by an average. - , no data. See definitions on p. 77]

\begin{tabular}{|c|c|c|c|c|c|c|c|c|c|c|}
\hline \multirow[b]{2}{*}{ 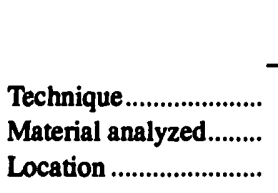 } & \multicolumn{5}{|c|}{$P$ (weight percent) } & \multicolumn{5}{|c|}{ Mn (weight percent) } \\
\hline & $\begin{array}{c}\text { WDXRF } \\
\text { Ash } \\
\text { R }\end{array}$ & $\begin{array}{l}\text { ICAP-AES } \\
\text { Ash } \\
\mathbf{R}\end{array}$ & $\begin{array}{l}\text { ICAP-AES } \\
\text { Ash } \\
\text { D }\end{array}$ & $\begin{array}{c}\text { WDXRF } \\
\text { WC } \\
\text { R }\end{array}$ & $\begin{array}{c}\text { DCAES } \\
\text { Ash } \\
\mathbf{R}\end{array}$ & $\begin{array}{c}\text { WDXRF } \\
\text { Ash } \\
\text { R }\end{array}$ & $\begin{array}{c}\text { ICAP-AES } \\
\text { Ash } \\
\text { R }\end{array}$ & $\begin{array}{c}\text { ICAP-AES } \\
\text { Ash } \\
\text { D }\end{array}$ & $\begin{array}{c}\text { DCAES } \\
\text { Ash } \\
\text { R }\end{array}$ & $\begin{array}{l}\text { DCAES } \\
\text { WC } \\
\mathbf{R}\end{array}$ \\
\hline 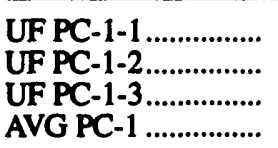 & $\begin{array}{c}\{0.005\} \\
\{.006\} \\
\overline{.006}\end{array}$ & $\begin{array}{r}0.0076 \\
.0080 \\
.0082 \\
.0079\end{array}$ & $\begin{array}{r}0.0059 \\
.0059 \\
.0059 \\
.0059\end{array}$ & $\begin{array}{l}<0.005 \\
<.005 \\
<.005 \\
-\end{array}$ & $\begin{array}{l}<0.0092 \\
<.0092 \\
<.0092 \\
-\end{array}$ & $\begin{array}{c}<0.01 \\
<.01 \\
- \\
-\end{array}$ & $\begin{array}{r}0.0041 \\
.0042 \\
.0041 \\
.0041\end{array}$ & $\begin{array}{r}0.0044 \\
.0044 \\
.0043 \\
.0044\end{array}$ & $\begin{array}{r}0.0055 \\
.0051 \\
.0058 \\
.0055\end{array}$ & $\begin{array}{r}0.0053 \\
.0059 \\
.0048 \\
.0053\end{array}$ \\
\hline 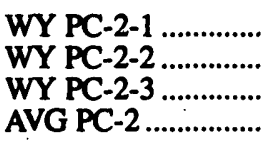 & $\begin{array}{c}\{.03\} \\
\{.03\} \\
.03\end{array}$ & $\begin{array}{l}.026 \\
.024 \\
.026 \\
.025\end{array}$ & $\begin{array}{l}.021 \\
.021 \\
.025 \\
.022\end{array}$ & $\begin{array}{l}.03 \\
.02 \\
.03 \\
.03\end{array}$ & $\begin{array}{l}.020 \\
.026 \\
.033 \\
.026\end{array}$ & $\begin{array}{l}<.007 \\
<.007 \\
- \\
-\end{array}$ & $\begin{array}{l}.0020 \\
.0021 \\
.0019 \\
.0020\end{array}$ & $\begin{array}{l}.0020 \\
.0020 \\
.0019 \\
.0020\end{array}$ & $\begin{array}{l}.0042 \\
.0027 \\
.0031 \\
.0033\end{array}$ & $\begin{array}{l}.0010 \\
.0016 \\
.0014 \\
.0013\end{array}$ \\
\hline 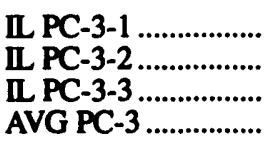 & $\begin{array}{l}\{.004\} \\
\{.004\} \\
\overline{.004}\end{array}$ & $\begin{array}{l}.0058 \\
.0060 \\
.0060 \\
.0059\end{array}$ & $\begin{array}{l}\{.004\} \\
\{.004\} \\
\{.003\} \\
.004\end{array}$ & $\begin{array}{l}<.005 \\
<.005 \\
<.005 \\
-\end{array}$ & $\begin{array}{l}<.011 \\
<.011 \\
<.011 \\
-\end{array}$ & $\begin{array}{c}<.01 \\
<.01 \\
- \\
-\end{array}$ & $\begin{array}{l}.0076 \\
.0076 \\
.0076 \\
.0076\end{array}$ & $\begin{array}{l}.0092 \\
.0084 \\
.0084 \\
.0087\end{array}$ & $\begin{array}{l}.011 \\
.010 \\
.011 \\
.011\end{array}$ & $\begin{array}{l}.015 \\
.015 \\
.017 \\
.016\end{array}$ \\
\hline 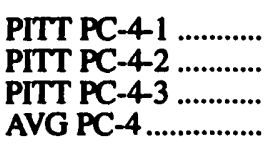 & $\begin{array}{c}\{.01\} \\
\frac{.01\}}{.01}\end{array}$ & $\begin{array}{l}.011 \\
.011 \\
.011 \\
.011\end{array}$ & $\begin{array}{l}.0092 \\
.0088 \\
.0060 \\
.0080\end{array}$ & $\begin{array}{l}.009 \\
.009 \\
.009 \\
.009\end{array}$ & $\begin{array}{l}<.0063 \\
<.0063 \\
<.0063 \\
-\end{array}$ & $\begin{array}{l}<.007 \\
<.007 \\
- \\
-\end{array}$ & $\begin{array}{l}.0018 \\
.0017 \\
.0017 \\
.0018\end{array}$ & $\begin{array}{l}.0021 \\
.0021 \\
.0020 \\
.0021\end{array}$ & $\begin{array}{l}.0030 \\
.0038 \\
.0039 \\
.0036\end{array}$ & $\begin{array}{l}.0016 \\
.0028 \\
.0018 \\
.0020\end{array}$ \\
\hline 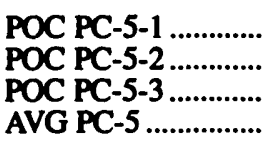 & $\begin{array}{c}\{.002\} \\
\{.002\} \\
.002\end{array}$ & $\begin{array}{l}.0022 \\
.0022 \\
.0021 \\
.0022\end{array}$ & $\begin{array}{r}.0023 \\
.0023 \\
\{.002\} \\
.0023\end{array}$ & $\begin{array}{l}<.005 \\
<.005 \\
<.005 \\
-\end{array}$ & $\begin{array}{l}<.0036 \\
<.0036 \\
<.0036 \\
-\end{array}$ & $\begin{array}{c}<.004 \\
<.004 \\
- \\
-\end{array}$ & $\begin{array}{l}.0016 \\
.0016 \\
.0016 \\
.0016\end{array}$ & $\begin{array}{l}.0018 \\
.0018 \\
.0019 \\
.0018\end{array}$ & $\begin{array}{l}.0024 \\
.0023 \\
.0026 \\
.0024\end{array}$ & $\begin{array}{l}.0016 \\
.0024 \\
.0017 \\
.0019\end{array}$ \\
\hline 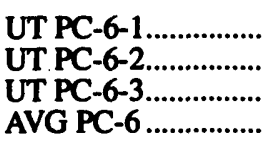 & $\begin{array}{l}\{.0001\} \\
\overline{-} \\
(.001)\end{array}$ & $\begin{array}{c}.00092 \\
.00097 \\
\overline{.00094}\end{array}$ & $\begin{array}{c}\{.0008\} \\
\{.0008\} \\
\{.0006\} \\
.0007\end{array}$ & $\begin{array}{l}<.005 \\
<.005 \\
<.005 \\
-\end{array}$ & $\begin{array}{c}<.0031 \\
<.0031 \\
.00074 \\
(.00074)\end{array}$ & $\begin{array}{c}<.004 \\
- \\
-\end{array}$ & $\begin{array}{l}.00041 \\
.00041 \\
\overline{.00041}\end{array}$ & $\begin{array}{l}.00043 \\
.00042 \\
.00041 \\
.00042\end{array}$ & $\begin{array}{l}.00064 \\
.00046 \\
.00074 \\
.00061\end{array}$ & - \\
\hline 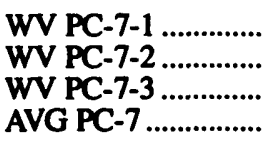 & $\frac{\{.007\}}{\overline{(.007)}}$ & $\begin{array}{l}.0089 \\
.0087 \\
.0074 \\
.0084\end{array}$ & $\begin{array}{c}\{.008\} \\
\{.008\} \\
\{.008\} \\
.008\end{array}$ & $\begin{array}{l}<.005 \\
<.005 \\
<.005 \\
-\end{array}$ & $\begin{array}{l}.017 \\
<.013 \\
<.013 \\
(.017)\end{array}$ & $\begin{array}{c}<.015 \\
-\end{array}$ & $\begin{array}{l}.0016 \\
.0015 \\
.0015 \\
.0015\end{array}$ & $\begin{array}{l}.0014 \\
.0014 \\
.0014 \\
.0014\end{array}$ & $\begin{array}{l}.0018 \\
.0023 \\
.0019 \\
.0020\end{array}$ & z \\
\hline 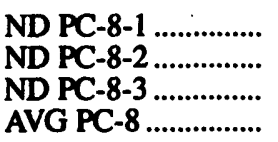 & $\frac{\{.02\}}{(\overline{02})}$ & $\begin{array}{l}.012 \\
.012 \\
.012 \\
.012\end{array}$ & $\begin{array}{l}.012 \\
.012 \\
.012 \\
.012\end{array}$ & $\begin{array}{l}.02 \\
.02 \\
.02 \\
.02\end{array}$ & $\begin{array}{l}.012 \\
.010 \\
.0093 \\
.011\end{array}$ & $\frac{\{.007\}}{-}$ & $\begin{array}{l}.0080 \\
.0079 \\
.0081 \\
.0080\end{array}$ & $\begin{array}{l}.0081 \\
.0083 \\
.0083 \\
.0082\end{array}$ & $\begin{array}{l}.010 \\
.010 \\
.010 \\
.010\end{array}$ & - \\
\hline
\end{tabular}


Appendix 1. Comparison of the concentrations of 51 elements determined by multiple analytical techniques in 8 Argonne Premium Coal samples-Continued.

[Analyses of splits for each sample are followed by an average. —, no data. See definitions on p. 77]

\begin{tabular}{|c|c|c|c|c|c|c|c|}
\hline \multirow[b]{2}{*}{ 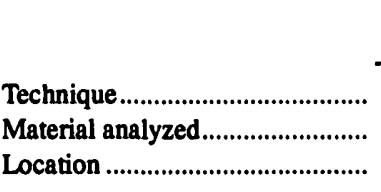 } & \multicolumn{2}{|c|}{ Li (ppm) } & \multicolumn{3}{|c|}{$\mathrm{Be}$ (ppm) } & \multicolumn{2}{|c|}{ B (ppm) } \\
\hline & $\begin{array}{l}\text { FAAS } \\
\text { Ash } \\
\mathbf{R}\end{array}$ & $\begin{array}{l}\text { ICAP-AES } \\
\text { Ash } \\
\text { D }\end{array}$ & $\begin{array}{l}\text { ICAP-AES } \\
\text { Ash } \\
\mathbf{R}\end{array}$ & $\begin{array}{l}\text { ICAP-AES } \\
\text { Ash } \\
\text { D }\end{array}$ & $\begin{array}{l}\text { DCAES } \\
\text { Ash } \\
\mathbf{R}\end{array}$ & $\begin{array}{c}\text { ICAP-AES } \\
\text { Ash } \\
\text { D }\end{array}$ & $\begin{array}{c}\text { DCAES } \\
\text { Ash } \\
\mathbf{R}\end{array}$ \\
\hline 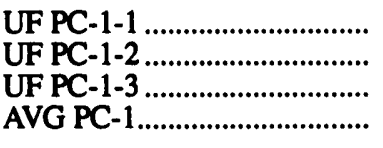 & $\begin{array}{l}15 \\
15 \\
15 \\
15\end{array}$ & $\begin{array}{l}15 \\
15 \\
15 \\
15\end{array}$ & $\begin{array}{l}1.5 \\
1.5 \\
1.5 \\
1.5\end{array}$ & $\begin{array}{l}1.5 \\
1.5 \\
1.5 \\
1.5\end{array}$ & $\begin{array}{l}1.5 \\
1.2 \\
1.5 \\
1.4\end{array}$ & $\begin{array}{l}35 \\
31 \\
49 \\
38\end{array}$ & $\begin{array}{l}19 \\
47 \\
24 \\
30\end{array}$ \\
\hline 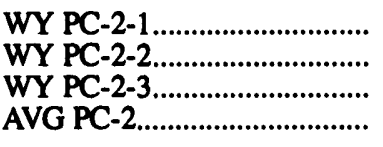 & $\begin{array}{l}4.1 \\
4.2 \\
4.1 \\
4.1\end{array}$ & $\begin{array}{l}3.9 \\
3.9 \\
3.9 \\
3.9\end{array}$ & $\begin{array}{l}.26 \\
.24 \\
.25 \\
.25\end{array}$ & $\begin{array}{l}\{.3\} \\
\{.3\} \\
\{.3\} \\
.3\end{array}$ & $\begin{array}{l}.14 \\
.14 \\
.15 \\
.14\end{array}$ & $\begin{array}{r}85 \\
110 \\
94 \\
96\end{array}$ & $\begin{array}{l}74 \\
63 \\
73 \\
70\end{array}$ \\
\hline 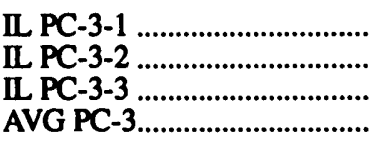 & $\begin{array}{l}7.8 \\
7.9 \\
7.8 \\
7.8\end{array}$ & $\begin{array}{l}7.9 \\
7.6 \\
7.5 \\
7.7\end{array}$ & $\begin{array}{l}.78 \\
.75 \\
.75 \\
.76\end{array}$ & $\begin{array}{l}\{.6\} \\
\{.6\} \\
\{.6\} \\
.6\end{array}$ & $\begin{array}{c}.89 \\
.96 \\
1.1 \\
.97\end{array}$ & $\begin{array}{l}160 \\
160 \\
160 \\
160\end{array}$ & $\begin{array}{l}120 \\
110 \\
130 \\
120\end{array}$ \\
\hline 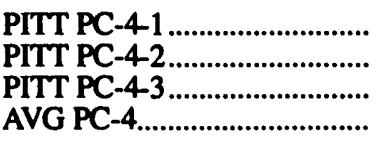 & $\begin{array}{l}8.7 \\
8.6 \\
8.6 \\
8.6\end{array}$ & $\begin{array}{l}9.2 \\
8.3 \\
8.2 \\
8.9\end{array}$ & $\begin{array}{l}.76 \\
.76 \\
.78 \\
.77\end{array}$ & $\begin{array}{l}(.7) \\
(.7) \\
(.7) \\
.7\end{array}$ & $\begin{array}{l}1.1 \\
1.2 \\
1.2 \\
1.2\end{array}$ & $\begin{array}{l}48 \\
49 \\
47 \\
48\end{array}$ & $\begin{array}{l}49 \\
53 \\
52 \\
51\end{array}$ \\
\hline 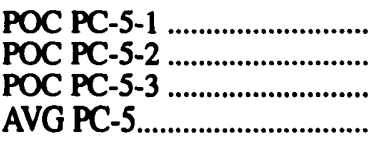 & $\begin{array}{l}\mathbf{5 . 8} \\
\mathbf{5 . 8} \\
\mathbf{5 . 8} \\
\mathbf{5 . 8}\end{array}$ & $\begin{array}{l}5.3 \\
5.3 \\
5.8 \\
5.5\end{array}$ & $\begin{array}{l}.80 \\
.80 \\
.80 \\
.80\end{array}$ & $\begin{array}{l}.80 \\
.80 \\
.80 \\
.80\end{array}$ & $\begin{array}{l}.74 \\
.58 \\
.69 \\
.67\end{array}$ & $\begin{array}{l}14 \\
13 \\
13 \\
13\end{array}$ & $\begin{array}{l}17 \\
16 \\
19 \\
17\end{array}$ \\
\hline 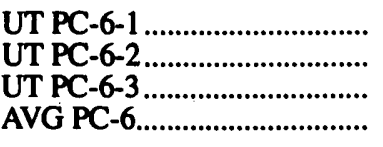 & $\begin{array}{l}5.1 \\
5.1 \\
5.1\end{array}$ & $\begin{array}{l}\mathbf{5 . 5} \\
\mathbf{5 . 5} \\
\mathbf{5 . 5} \\
\mathbf{5 . 5}\end{array}$ & $\begin{array}{l}.13 \\
.12 \\
.13\end{array}$ & $\begin{array}{l}\{.1\} \\
\{.1\} \\
.1\}\end{array}$ & $\begin{array}{l}.15 \\
.24 \\
.20 \\
.20\end{array}$ & $\begin{array}{l}120 \\
120 \\
130 \\
130\end{array}$ & $\begin{array}{l}<46 \\
<46 \\
<46 \\
-\end{array}$ \\
\hline 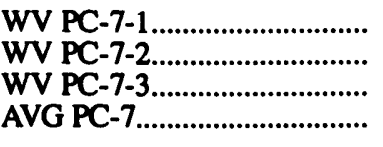 & $\begin{array}{l}29 \\
29 \\
29 \\
29\end{array}$ & $\begin{array}{l}27 \\
27.9 \\
27 \\
27\end{array}$ & $\begin{array}{l}1.9 \\
1.9 \\
1.9 \\
1.9\end{array}$ & $\begin{array}{l}2.1 \\
2.1 \\
2.1 \\
2.1\end{array}$ & $\begin{array}{l}2.9 \\
3.1 \\
3.1 \\
3.0\end{array}$ & $\begin{array}{l}39 \\
78 \\
51 \\
56\end{array}$ & $\begin{array}{l}29 \\
93 \\
49 \\
57\end{array}$ \\
\hline 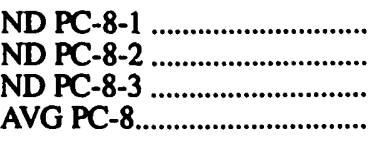 & $\begin{array}{l}2.7 \\
2.7 \\
2.8 \\
2.7\end{array}$ & $\begin{array}{l}2.7 \\
2.7 \\
2.7 \\
2.7\end{array}$ & $\begin{array}{l}.18 \\
.17 \\
.18\end{array}$ & $\begin{array}{l}\{.2\} \\
\{.2\} \\
\{.2\} \\
.2\end{array}$ & $\begin{array}{l}.27 \\
.33 \\
.23 \\
.28\end{array}$ & $\begin{array}{l}79 \\
81 \\
79 \\
79\end{array}$ & $\begin{array}{l}48 \\
76 \\
77 \\
67\end{array}$ \\
\hline
\end{tabular}


Appendix 1. Comparison of the concentrations of 51 elements determined by multiple analytical techniques in 8 Argonne Premium Coal samples-Continued.

[Analyses of splits for each sample are followed by an average. —, no data. See definitions on p. 77]

\begin{tabular}{|c|c|c|c|c|c|c|c|}
\hline \multirow[b]{2}{*}{ 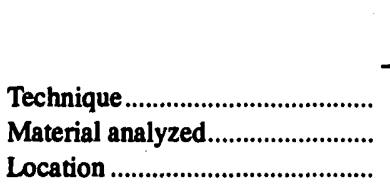 } & \multicolumn{3}{|c|}{ Sc (ppm) } & \multicolumn{4}{|c|}{$\mathrm{V}(\mathrm{ppm})$} \\
\hline & $\begin{array}{c}\text { WAA } \\
\mathbf{W C} \\
\mathbf{R}\end{array}$ & $\begin{array}{l}\text { ICAP-AES } \\
\text { Ash } \\
\text { D }\end{array}$ & $\begin{array}{c}\text { DCAES } \\
\text { Ash } \\
\mathbf{R}\end{array}$ & $\begin{array}{l}\text { ICAP-AES } \\
\text { Ash } \\
\mathbf{R}\end{array}$ & $\begin{array}{c}\text { ICAP-AES } \\
\text { Ash } \\
\text { D }\end{array}$ & $\begin{array}{c}\text { DCAES } \\
\text { Ash } \\
\text { R }\end{array}$ & $\begin{array}{l}\text { DCAES } \\
\text { WC } \\
\mathbf{R}\end{array}$ \\
\hline 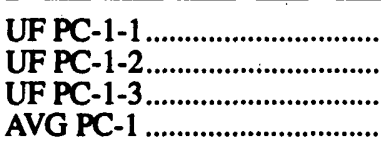 & $\begin{array}{l}4.04 \\
4.01 \\
4.14 \\
4.06\end{array}$ & $\begin{array}{l}3.9 \\
3.9 \\
3.9 \\
3.9\end{array}$ & $\begin{array}{l}2.6 \\
1.5 \\
2.2 \\
2.1\end{array}$ & $\begin{array}{l}26 \\
26 \\
26 \\
26\end{array}$ & $\begin{array}{l}27 \\
27 \\
27 \\
27\end{array}$ & $\begin{array}{l}18 \\
13 \\
17 \\
16\end{array}$ & $\begin{array}{l}38 \\
45 \\
41 \\
41\end{array}$ \\
\hline $\begin{array}{l}\text { WY PC-2-1 } \\
\text { WY PC-2-2 } \\
\text { WY PC-2-3 } \\
\text { AVG PC-2 }\end{array}$ & $\begin{array}{l}1.67 \\
1.69 \\
1.67 \\
1.68\end{array}$ & $\begin{array}{l}1.6 \\
1.6 \\
1.7 \\
1.6\end{array}$ & $\begin{array}{l}1.0 \\
1.4 \\
1.5 \\
1.3\end{array}$ & $\begin{array}{l}14 \\
14 \\
14 \\
14\end{array}$ & $\begin{array}{l}14 \\
14 \\
14 \\
14\end{array}$ & $\begin{array}{r}7.3 \\
9.3 \\
10.0 \\
9.0\end{array}$ & $\begin{array}{l}10 \\
14 \\
17 \\
14\end{array}$ \\
\hline 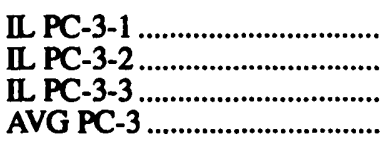 & $\begin{array}{l}2.55 \\
2.57 \\
2.64 \\
2.59\end{array}$ & $\begin{array}{l}2.8 \\
2.8 \\
2.6 \\
2.7\end{array}$ & $\begin{array}{l}2.5 \\
2.6 \\
2.8 \\
2.6\end{array}$ & $\begin{array}{l}32 \\
32 \\
31 \\
32\end{array}$ & $\begin{array}{l}39 \\
37 \\
36 \\
37\end{array}$ & $\begin{array}{l}23 \\
23 \\
26 \\
24\end{array}$ & $\begin{array}{l}52 \\
59 \\
44 \\
52\end{array}$ \\
\hline $\begin{array}{l}\text { PITT PC-4-1 } \\
\text { PITT PC-4-2 } \\
\text { PITT PC-4-3 } \\
\text { AVG PC-4 }\end{array}$ & $\begin{array}{l}2.61 \\
2.56 \\
2.55 \\
2.57\end{array}$ & $\begin{array}{l}2.5 \\
2.5 \\
2.5 \\
2.5\end{array}$ & $\begin{array}{l}1.8 \\
1.7 \\
2.0 \\
1.9\end{array}$ & $\begin{array}{l}15 \\
15 \\
15 \\
15\end{array}$ & $\begin{array}{l}17 \\
17 \\
17 \\
17\end{array}$ & $\begin{array}{l}12 \\
12 \\
14 \\
13\end{array}$ & $\begin{array}{l}20 \\
25 \\
27 \\
24\end{array}$ \\
\hline 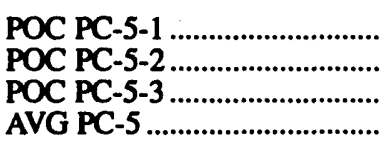 & $\begin{array}{l}1.80 \\
1.79 \\
1.77 \\
1.79\end{array}$ & $\begin{array}{l}1.8 \\
1.8 \\
1.8 \\
1.8\end{array}$ & $\begin{array}{l}1.3 \\
1.3 \\
1.5 \\
1.3\end{array}$ & $\begin{array}{l}11 \\
11 \\
11 \\
11\end{array}$ & $\begin{array}{l}12 \\
12 \\
12 \\
12\end{array}$ & $\begin{array}{l}6.9 \\
6.4 \\
7.9 \\
7.1\end{array}$ & $\begin{array}{l}16 \\
21 \\
18 \\
18\end{array}$ \\
\hline 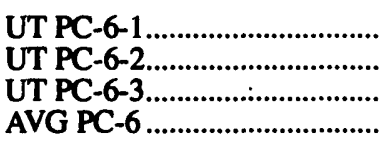 & $\begin{array}{l}.832 \\
.801 \\
.805 \\
.813\end{array}$ & $\begin{array}{l}.78 \\
.74 \\
.74 \\
.75\end{array}$ & $\begin{array}{l}.74 \\
.69 \\
.64 \\
.69\end{array}$ & $\begin{array}{l}4.0 \\
4.0 \\
4.0\end{array}$ & $\begin{array}{l}4.6 \\
4.4 \\
4.4 \\
4.5\end{array}$ & $\begin{array}{l}3.8 \\
3.6 \\
3.6 \\
3.7\end{array}$ & $\bar{z}$ \\
\hline 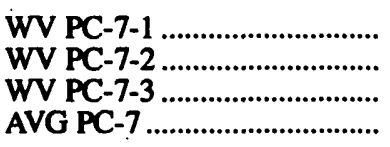 & $\begin{array}{l}7.69 \\
7.54 \\
7.61 \\
7.62\end{array}$ & $\begin{array}{l}7.4 \\
7.4 \\
7.4 \\
7.4\end{array}$ & $\begin{array}{l}7.0 \\
6.0 \\
6.2 \\
6.4\end{array}$ & $\begin{array}{l}43 \\
45 \\
43 \\
44\end{array}$ & $\begin{array}{l}43 \\
43 \\
43 \\
43\end{array}$ & $\begin{array}{l}31 \\
35 \\
29 \\
32\end{array}$ & $\bar{z}$ \\
\hline 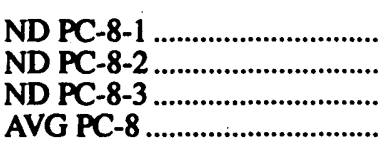 & $\begin{array}{l}.846 \\
.828 \\
.865 \\
.846\end{array}$ & $\begin{array}{c}\{.8\} \\
\{.8\} \\
\{.8\} \\
.8\end{array}$ & $\begin{array}{l}.87 \\
.86 \\
.95 \\
.90\end{array}$ & $\begin{array}{l}3.5 \\
3.4 \\
3.6 \\
3.5\end{array}$ & $\begin{array}{l}3.9 \\
3.8 \\
3.9 \\
3.9\end{array}$ & $\begin{array}{l}3.6 \\
3.6 \\
3.5 \\
3.6\end{array}$ & $\frac{-}{-}$ \\
\hline
\end{tabular}


Appendix 1. Comparison of the concentrations of 51 elements determined by multiple analytical techniques in 8 Argonne Premium Coal samples-Continued.

[Analyses of splits for each sample are followed by an average. —, no data. See definitions on p. 77]

\begin{tabular}{|c|c|c|c|c|c|c|c|c|c|c|c|c|}
\hline \multirow[b]{2}{*}{$\begin{array}{l}\text { Technique ................. } \\
\text { Material analyzed....... } \\
\text { Location ...................... }\end{array}$} & \multicolumn{7}{|c|}{$\mathrm{Cr}(\mathrm{ppm})$} & \multicolumn{5}{|c|}{$\mathrm{Co}(\mathrm{ppm})$} \\
\hline & $\begin{array}{c}\text { INAA } \\
\text { WC } \\
\mathbf{R}\end{array}$ & $\begin{array}{c}\text { EDXRF } \\
\text { Ash } \\
\text { R }\end{array}$ & $\begin{array}{l}\text { ICAP-AES } \\
\text { Ash } \\
\mathbf{R}\end{array}$ & $\begin{array}{c}\text { ICAP-AES } \\
\text { Ash } \\
\text { D }\end{array}$ & $\begin{array}{c}\text { EDXRF } \\
\text { WC } \\
\mathbf{R}\end{array}$ & $\begin{array}{c}\text { DCAES } \\
\text { Ash } \\
\text { R }\end{array}$ & $\begin{array}{c}\text { DCAES } \\
\text { WC } \\
\mathbf{R}\end{array}$ & $\begin{array}{c}\text { INAA } \\
\text { WC } \\
\mathbf{R}\end{array}$ & $\begin{array}{c}\text { FAAS } \\
\text { Ash } \\
\mathbf{R}\end{array}$ & $\begin{array}{c}\text { ICAP-AES } \\
\text { Ash } \\
\text { D }\end{array}$ & $\begin{array}{c}\text { DCAES } \\
\text { Ash } \\
\mathbf{R}\end{array}$ & $\begin{array}{l}\text { DCAES } \\
\text { WC } \\
\text { R }\end{array}$ \\
\hline 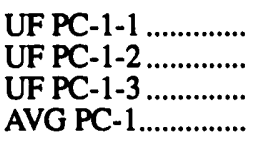 & $\begin{array}{l}20.4 \\
20.3 \\
20.4 \\
20.3\end{array}$ & $\begin{array}{l}26.1 \\
26.5 \\
26.5 \\
26.0\end{array}$ & $\begin{array}{l}20 \\
19 \\
20 \\
20\end{array}$ & $\begin{array}{l}22 \\
22 \\
22 \\
22\end{array}$ & $\begin{array}{l}15 \\
23 \\
19 \\
19\end{array}$ & $\begin{array}{l}22 \\
17 \\
19 \\
19\end{array}$ & $\begin{array}{l}32 \\
38 \\
26 \\
32\end{array}$ & $\begin{array}{l}\mathbf{5 . 2 7} \\
\mathbf{5 . 4 1} \\
\mathbf{5 . 3 1} \\
\mathbf{5 . 3 3}\end{array}$ & $\begin{array}{l}5.1 \\
5.1 \\
4.7 \\
5.0\end{array}$ & $\begin{array}{l}5.3 \\
5.3 \\
5.4 \\
5.3\end{array}$ & $\begin{array}{l}3.8 \\
3.0 \\
3.9 \\
3.5\end{array}$ & $\begin{array}{l}5 \\
5 \\
5 \\
5\end{array}$ \\
\hline $\begin{array}{l}\text { WY PC-2-1......... } \\
\text { WY PC-2-2............ } \\
\text { WY PC-2-3........ } \\
\text { AVG PC-2 } \ldots \ldots \ldots \ldots \ldots . . .\end{array}$ & $\begin{array}{l}5.7 \\
6.22 \\
6.23 \\
6.1\end{array}$ & $\begin{array}{c}7.3 \\
8.2 \\
\{9.18\} \\
8.2\end{array}$ & $\begin{array}{l}6.2 \\
6.4 \\
6.0 \\
6.2\end{array}$ & $\begin{array}{l}6.3 \\
6.5 \\
6.4 \\
6.4\end{array}$ & $\begin{array}{r}3 \\
5 \\
-4\end{array}$ & $\begin{array}{l}4.8 \\
6.3 \\
5.9 \\
5.7\end{array}$ & $\begin{array}{l}8 \\
6 \\
8 \\
7\end{array}$ & $\begin{array}{l}1.66 \\
1.73 \\
1.65 \\
1.68\end{array}$ & $\begin{array}{l}1.6 \\
1.6 \\
1.6 \\
1.6\end{array}$ & $\begin{array}{l}1.5 \\
1.8 \\
1.7 \\
1.7\end{array}$ & $\begin{array}{l}1.0 \\
1.4 \\
1.4 \\
1.3\end{array}$ & $\begin{array}{l}<5 \\
<5 \\
<5 \\
-\end{array}$ \\
\hline 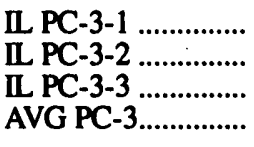 & $\begin{array}{l}33.7 \\
32.5 \\
33.2 \\
33.1\end{array}$ & $\begin{array}{l}42.9 \\
42.9 \\
43.7 \\
43.2\end{array}$ & $\begin{array}{l}29 \\
32 \\
31 \\
31\end{array}$ & $\begin{array}{l}41 \\
34 \\
34 \\
36\end{array}$ & $\begin{array}{l}29 \\
36 \\
41 \\
35\end{array}$ & $\begin{array}{l}36 \\
36 \\
42 \\
38\end{array}$ & $\begin{array}{l}54 \\
57 \\
47 \\
52\end{array}$ & $\begin{array}{l}4.21 \\
4.21 \\
4.53 \\
4.31\end{array}$ & $\begin{array}{l}4.2 \\
4.5 \\
4.2 \\
4.3\end{array}$ & $\begin{array}{l}4.7 \\
4.4 \\
4.2 \\
4.4\end{array}$ & $\begin{array}{l}3.6 \\
3.4 \\
4.2 \\
3.7\end{array}$ & $\begin{array}{l}<5 \\
<5 \\
<5 \\
-\end{array}$ \\
\hline $\begin{array}{l}\text { PITT PC-4-1 .......... } \\
\text { PITT PC-4-2 .......... } \\
\text { PITT PC-4-3......... } \\
\text { AVG PC-4................... }\end{array}$ & $\begin{array}{l}15.0 \\
15.0 \\
14.5 \\
14.8\end{array}$ & $\begin{array}{l}18.4 \\
17.5 \\
17.9 \\
17.9\end{array}$ & $\begin{array}{l}15 \\
14 \\
13 \\
14\end{array}$ & $\begin{array}{l}16 \\
16 \\
16 \\
16\end{array}$ & $\begin{array}{r}6 \\
10 \\
9 \\
8\end{array}$ & $\begin{array}{l}20 \\
17 \\
20 \\
19\end{array}$ & $\begin{array}{l}23 \\
27 \\
21 \\
24\end{array}$ & $\begin{array}{l}2.65 \\
2.61 \\
2.60 \\
2.62\end{array}$ & $\begin{array}{l}2.4 \\
2.6 \\
2.4 \\
2.4\end{array}$ & $\begin{array}{l}2.6 \\
2.7 \\
2.6 \\
2.6\end{array}$ & $\begin{array}{l}2.8 \\
2.3 \\
2.8 \\
2.6\end{array}$ & $\begin{array}{l}<5 \\
<5 \\
<5 \\
-\end{array}$ \\
\hline 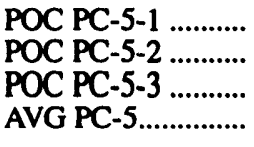 & $\begin{array}{l}9.3 \\
9.06 \\
8.85 \\
9.1\end{array}$ & $\begin{array}{l}12.5 \\
11.9 \\
12.5 \\
12.3\end{array}$ & $\begin{array}{l}9.5 \\
8.5 \\
9.5 \\
9.2\end{array}$ & $\begin{array}{r}10.1 \\
9.5 \\
9.5 \\
9.7\end{array}$ & $\begin{array}{l}5 \\
7 \\
4 \\
5\end{array}$ & $\begin{array}{l}9.0 \\
8.0 \\
9.5 \\
8.8\end{array}$ & $\begin{array}{l}17 \\
17 \\
14 \\
16\end{array}$ & $\begin{array}{l}4.09 \\
4.13 \\
3.98 \\
4.07\end{array}$ & $\begin{array}{l}3.8 \\
3.8 \\
3.8 \\
3.8\end{array}$ & $\begin{array}{l}4.0 \\
3.9 \\
4.0 \\
4.0\end{array}$ & $\begin{array}{l}2.4 \\
2.3 \\
3.0 \\
2.6\end{array}$ & $\begin{array}{l}5 \\
5 \\
5 \\
5\end{array}$ \\
\hline $\begin{array}{l}\text { UT PC-6-1 } \\
\text { UT PC-6-2.............. } \\
\text { UT PC-6-3............ } \\
\text { AVG PC-6.................. }\end{array}$ & $\begin{array}{l}\mathbf{5 . 2 5} \\
\mathbf{5 . 0 3} \\
\mathbf{5 . 6 2} \\
\mathbf{5 . 3 0}\end{array}$ & $\overline{-}$ & $\begin{array}{l}5.1 \\
4.6 \\
\frac{-}{4.8}\end{array}$ & $\begin{array}{l}\mathbf{5 . 5} \\
\mathbf{5 . 1} \\
\mathbf{5 . 1} \\
\mathbf{5 . 2}\end{array}$ & $\begin{array}{l}<10 \\
<10 \\
<10 \\
-\end{array}$ & $\begin{array}{l}5.1 \\
3.9 \\
5.5 \\
4.8\end{array}$ & $\frac{-}{-}$ & $\begin{array}{l}1.01 \\
.992 \\
1.00 \\
1.00\end{array}$ & $\begin{array}{l}.83 \\
.83 \\
-.83\end{array}$ & $\begin{array}{l}.97 \\
.92 \\
.92 \\
.94\end{array}$ & $\begin{array}{l}.69 \\
.60 \\
.64 \\
.64\end{array}$ & $\frac{-}{-}$ \\
\hline $\begin{array}{l}\text { WV PC- } 7-1 \ldots \ldots \ldots \\
\text { WV PC- } 7-2 \ldots \ldots \ldots \ldots \\
\text { WV PC- } 7-3 \ldots \ldots \ldots \ldots \\
\text { AVG PC- } 7 \ldots \ldots \ldots \ldots \ldots\end{array}$ & $\begin{array}{l}36.2 \\
35.6 \\
35.7 \\
35.8\end{array}$ & $\begin{array}{l}46.2 \\
45.4 \\
46.0 \\
45.9\end{array}$ & $\begin{array}{l}41 \\
41 \\
39 \\
40\end{array}$ & $\begin{array}{l}39 \\
39 \\
39 \\
39\end{array}$ & $\begin{array}{l}50 \\
48 \\
48 \\
49\end{array}$ & $\begin{array}{l}43 . \\
35 \\
41 \\
39\end{array}$ & $\frac{-}{z}$ & $\begin{array}{l}7.65 \\
7.86 \\
7.72 \\
7.74\end{array}$ & $\begin{array}{l}7.8 \\
8.4 \\
8.2 \\
8.1\end{array}$ & $\begin{array}{l}7.4 \\
7.6 \\
7.4 \\
7.5\end{array}$ & $\begin{array}{l}7.0 \\
5.8 \\
6.0 \\
6.3\end{array}$ & - \\
\hline 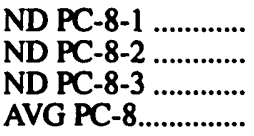 & $\begin{array}{l}2.23 \\
2.16 \\
2.33 \\
2.24\end{array}$ & $\begin{array}{l}2.5 \\
2.7 \\
2.8 \\
2.6\end{array}$ & $\begin{array}{l}2.6 \\
2.5 \\
2.3 \\
2.4\end{array}$ & $\begin{array}{l}2.2 \\
2.2 \\
2.5 \\
2.3\end{array}$ & $\begin{array}{l}<10 \\
<10 \\
<10 \\
-\end{array}$ & $\begin{array}{l}2.4 \\
2.4 \\
2.5 \\
2.4\end{array}$ & $\frac{-}{-}$ & $\begin{array}{l}.771 \\
.761 \\
.802 \\
.778\end{array}$ & $\begin{array}{l}<1 \\
<1 \\
<1 \\
-\end{array}$ & $\begin{array}{c}\{.8\} \\
\{1\} \\
\{.8\} \\
.9\end{array}$ & $\begin{array}{l}.54 \\
.57 \\
.54 \\
.55\end{array}$ & - \\
\hline
\end{tabular}


Appendix 1. Comparison of the concentrations of 51 elements determined by multiple analytical techniques in 8 Argonne Premium Coal samples-Continued.

[Analyses of splits for each sample are followed by an average. -, no data. See definitions on p. 77]

\begin{tabular}{|c|c|c|c|c|c|c|c|c|c|c|c|c|c|}
\hline \multirow[b]{2}{*}{$\begin{array}{l}\text { Technique................. } \\
\text { Material analyzed ... } \\
\text { Location ..................... }\end{array}$} & \multicolumn{7}{|c|}{$\mathrm{Ni}$ (ppm) } & \multicolumn{6}{|c|}{$\mathrm{Cu}(\mathrm{ppm})$} \\
\hline & $\begin{array}{l}\text { NAA } \\
\text { WC } \\
\mathbf{R}\end{array}$ & $\begin{array}{c}\text { EDXRF } \\
\text { Ash } \\
\text { R }\end{array}$ & $\begin{array}{c}\text { ICAP-AES } \\
\text { Ash } \\
\text { R }\end{array}$ & $\begin{array}{c}\text { ICAP-AES } \\
\text { Ash } \\
\text { D }\end{array}$ & $\begin{array}{c}\text { EDXRF } \\
\text { WC } \\
\mathbf{R}\end{array}$ & $\begin{array}{c}\text { DCAES } \\
\text { Ash } \\
\text { R }\end{array}$ & $\begin{array}{c}\text { DCAES } \\
\text { WC } \\
\mathbf{R}\end{array}$ & $\begin{array}{l}\text { EDXRF } \\
\text { Ash } \\
\text { R }\end{array}$ & $\begin{array}{c}\text { ICAP-AES } \\
\text { Ash } \\
\text { R }\end{array}$ & $\begin{array}{l}\text { ICAP-AES } \\
\text { Ash } \\
\text { D }\end{array}$ & $\begin{array}{c}\text { EDXRF } \\
\text { WC } \\
\text { R }\end{array}$ & $\begin{array}{c}\text { DCAES } \\
\text { Ash } \\
\text { R }\end{array}$ & $\begin{array}{l}\text { DCAES } \\
\text { WC } \\
\text { R }\end{array}$ \\
\hline 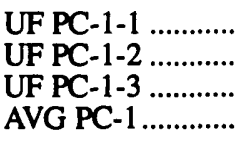 & $\begin{array}{l}15.9 \\
13.2 \\
14.3 \\
14.5\end{array}$ & $\begin{array}{l}14.0 \\
15.9 \\
11 \\
14\end{array}$ & $\begin{array}{l}15 \\
14 \\
15 \\
14\end{array}$ & $\begin{array}{l}15 \\
15 \\
15 \\
17\end{array}$ & $\begin{array}{l}27 \\
22 \\
21 \\
23\end{array}$ & $\begin{array}{l}14 \\
13 \\
14 \\
14\end{array}$ & $\begin{array}{l}22 \\
29 \\
24 \\
25\end{array}$ & $\begin{array}{l}19.7 \\
20.5 \\
21.3 \\
20.4\end{array}$ & $\begin{array}{l}19 \\
19 \\
19 \\
19\end{array}$ & $\begin{array}{l}19 \\
19 \\
18 \\
19\end{array}$ & $\begin{array}{l}20 \\
18 \\
17 \\
18\end{array}$ & $\begin{array}{l}17 \\
16 \\
19 \\
17\end{array}$ & $\begin{array}{l}20 \\
18 \\
16 \\
18\end{array}$ \\
\hline 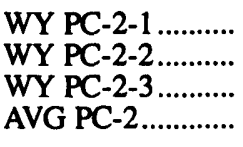 & $\begin{array}{l}4.4 \\
5.4 \\
5.0 \\
4.9\end{array}$ & $\begin{array}{l}4.3 \\
3.9 \\
3.7 \\
3.9\end{array}$ & $\begin{array}{l}4.9 \\
4.7 \\
5.2 \\
4.9\end{array}$ & $\begin{array}{l}4.7 \\
4.9 \\
4.7 \\
4.8\end{array}$ & $\begin{array}{l}9 \\
7 \\
8 \\
8\end{array}$ & $\begin{array}{l}4.8 \\
5.4 \\
5.4 \\
5.2\end{array}$ & $\begin{array}{l}<10 \\
<10 \\
<10 \\
-\end{array}$ & $\begin{array}{l}12.1 \\
13.4 \\
13.1 \\
12.9\end{array}$ & $\begin{array}{l}12 \\
12 \\
13 \\
12\end{array}$ & $\begin{array}{l}13 \\
14 \\
14 \\
14\end{array}$ & $\begin{array}{l}18 \\
17 \\
17 \\
17\end{array}$ & $\begin{array}{l}11 \\
14 \\
14 \\
13\end{array}$ & $\begin{array}{c}5.0 \\
10 \\
6.0 \\
7\end{array}$ \\
\hline 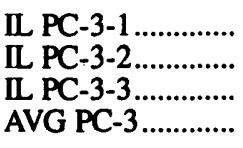 & $\begin{array}{l}24.2 \\
17.8 \\
21.0 \\
21.0\end{array}$ & $\begin{array}{l}14 \\
20 \\
19 \\
18\end{array}$ & $\begin{array}{l}18 \\
19 \\
18 \\
18\end{array}$ & $\begin{array}{c}\{29\} \\
19 \\
19 \\
19\end{array}$ & $\begin{array}{l}33 \\
30 \\
33 \\
32\end{array}$ & $\begin{array}{l}21 \\
19 \\
24 \\
22\end{array}$ & $\begin{array}{l}28 \\
35 \\
37 \\
33\end{array}$ & $\begin{array}{l}11 \\
9.4 \\
8.7 \\
9.6\end{array}$ & $\begin{array}{l}10 \\
10 \\
10 \\
10\end{array}$ & $\begin{array}{l}11 \\
11 \\
10 \\
11\end{array}$ & $\begin{array}{l}15 \\
13 \\
15 \\
14\end{array}$ & $\begin{array}{c}13 \\
11 \\
9.4 \\
11\end{array}$ & $\begin{array}{c}9.0 \\
10 \\
9.0 \\
9\end{array}$ \\
\hline $\begin{array}{l}\text { PITT PC-4-1 ........ } \\
\text { PITT PC-4-2 ........ } \\
\text { PITT PC-4-3 ........ } \\
\text { AVG PC-4 ........... }\end{array}$ & $\begin{array}{r}9.4 \\
11.3 \\
<12 \\
10.3\end{array}$ & $\begin{array}{r}9.0 \\
8.8 \\
10.3 \\
9.3\end{array}$ & $\begin{array}{l}9.1 \\
8.3 \\
8.1 \\
8.5\end{array}$ & $\begin{array}{l}8.9 \\
9.2 \\
9.2 \\
9.1\end{array}$ & $\begin{array}{l}17 \\
11 \\
15 \\
14\end{array}$ & $\begin{array}{l}14 \\
12 \\
13 \\
13\end{array}$ & $\begin{array}{l}13 \\
14 \\
11 \\
12\end{array}$ & $\begin{array}{l}6.4 \\
6.1 \\
6.1 \\
6.2\end{array}$ & $\begin{array}{l}\mathbf{5 . 5} \\
\mathbf{5 . 3} \\
\mathbf{5 . 5} \\
\mathbf{5 . 5}\end{array}$ & $\begin{array}{l}5.4 \\
6.2 \\
5.7 \\
5.8\end{array}$ & $\begin{array}{r}10 \\
9 \\
10 \\
10\end{array}$ & $\begin{array}{l}5.3 \\
8.2 \\
6.1 \\
6.5\end{array}$ & $\begin{array}{l}5.0 \\
6.0 \\
7.0 \\
6\end{array}$ \\
\hline 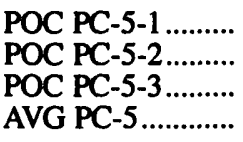 & $\begin{array}{l}9.2 \\
8.5 \\
8.2 \\
8.6\end{array}$ & $\begin{array}{l}\mathbf{7 . 0 0} \\
\mathbf{7 . 7 4} \\
\mathbf{8 . 0} \\
\mathbf{7 . 5 8}\end{array}$ & $\begin{array}{l}6.9 \\
6.4 \\
6.9 \\
6.7\end{array}$ & $\begin{array}{l}7.4 \\
7.4 \\
7.4 \\
7.4\end{array}$ & $\begin{array}{r}11 \\
9 \\
12 \\
11\end{array}$ & $\begin{array}{l}6.4 \\
5.8 \\
7.4 \\
6.5\end{array}$ & $\begin{array}{r}11 \\
11 \\
<10 \\
11\end{array}$ & $\begin{array}{l}12.7 \\
13.0 \\
11.9 \\
12.5\end{array}$ & $\begin{array}{l}12 \\
12 \\
12 \\
12\end{array}$ & $\begin{array}{l}16 \\
16 \\
16 \\
16\end{array}$ & $\begin{array}{l}16 \\
16 \\
19 \\
17\end{array}$ & $\begin{array}{l}22 \\
15 \\
20 \\
19\end{array}$ & $\begin{array}{l}18 \\
13 \\
27 \\
19\end{array}$ \\
\hline $\begin{array}{l}\text { UT PC-6-1 } \\
\text { UT PC-6-2 } \\
\text { UT PC-6............ } \\
\text { AVG PC-6.............. }\end{array}$ & $\begin{array}{l}<3 \\
3.2 \\
3.7 \\
3.4\end{array}$ & $\bar{z}$ & $\begin{array}{l}3.4 \\
\frac{3.3}{3.3}\end{array}$ & $\begin{array}{l}3.6 \\
3.4 \\
3.5 \\
3.5\end{array}$ & $\begin{array}{l}5 \\
5 \\
5 \\
5\end{array}$ & $\begin{array}{l}3.9 \\
4.1 \\
4.0 \\
4.0\end{array}$ & - & $\begin{array}{l}- \\
-\end{array}$ & $\begin{array}{l}3.9 \\
3.8 \\
\frac{3.8}{3}\end{array}$ & $\begin{array}{l}4.3 \\
4.2 \\
4.1 \\
4.2\end{array}$ & $\begin{array}{l}8 \\
8 \\
8 \\
8\end{array}$ & $\begin{array}{l}3.2 \\
2.4 \\
3.0 \\
2.9\end{array}$ & - \\
\hline 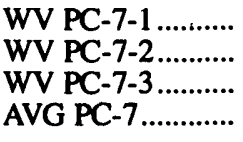 & $\begin{array}{l}14.0 \\
18 \\
14.3 \\
15.4\end{array}$ & $\begin{array}{l}18 \\
16 \\
17 \\
17\end{array}$ & $\begin{array}{l}16 \\
16 \\
16 \\
16\end{array}$ & $\begin{array}{l}16 \\
16 \\
16 \\
16\end{array}$ & $\begin{array}{l}17 \\
18 \\
19 \\
18\end{array}$ & $\begin{array}{l}23 \\
19 \\
21 \\
21\end{array}$ & $\overline{-}$ & $\begin{array}{l}25.2 \\
22.3 \\
23.3 \\
23.6\end{array}$ & $\begin{array}{l}19 \\
19 \\
19 \\
19\end{array}$ & $\begin{array}{l}21 \\
21 \\
21 \\
21\end{array}$ & $\begin{array}{l}30 \\
30 \\
32 \\
31\end{array}$ & $\begin{array}{l}17 \\
16 \\
13 \\
16\end{array}$ & - \\
\hline 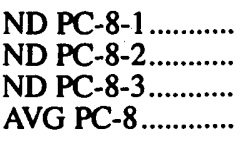 & $\begin{array}{l}<5 \\
<3 \\
<3 \\
\end{array}$ & $\begin{array}{l}2.4 \\
1.6 \\
1.8 \\
1.9\end{array}$ & $\begin{array}{l}1.4 \\
1.4 \\
1.1 \\
1.3\end{array}$ & $\begin{array}{l}1.3 \\
1.5 \\
1.4 \\
1.4\end{array}$ & $\begin{array}{r}4 \\
10 \\
4 \\
6\end{array}$ & $\begin{array}{l}1.6 \\
1.6 \\
2.1 \\
1.8\end{array}$ & $\overline{-}$ & $\begin{array}{l}3.4 \\
3.3 \\
3.2 \\
3.3\end{array}$ & $\begin{array}{l}5.6 \\
3.5 \\
4.9 \\
4.7\end{array}$ & $\begin{array}{r}4.5 \\
4.8 \\
\{12\} \\
4.6\end{array}$ & $\begin{array}{r}8 \\
10 \\
10 \\
9\end{array}$ & $\begin{array}{l}3.9 \\
3.8 \\
7.1 \\
4.9\end{array}$ & $\frac{-}{-}$ \\
\hline
\end{tabular}


Appendix 1. Comparison of the concentrations of 51 elements determined by multiple analytical techniques in 8 Argonne Premium Coal samples-Continued.

[Analyses of splits for each sample are followed by an average. -, no data. See definitions on p. 77]

\begin{tabular}{|c|c|c|c|c|c|c|c|c|c|c|c|c|}
\hline \multirow[b]{2}{*}{$\begin{array}{l}\text { Technique ................. } \\
\text { Material analyzed..... } \\
\text { Location ...................... }\end{array}$} & \multicolumn{6}{|c|}{$\mathrm{Zn}(\mathrm{ppm})$} & \multicolumn{3}{|c|}{$\mathrm{Ga}(\mathrm{ppm})$} & \multicolumn{3}{|c|}{$\mathrm{Ge}(\mathrm{ppm})$} \\
\hline & $\begin{array}{c}\text { INAA } \\
\text { WC } \\
\mathbf{R}\end{array}$ & $\begin{array}{c}\text { EDXRF } \\
\text { Ash } \\
\text { R }\end{array}$ & $\begin{array}{c}\text { ICAP-AES } \\
\text { Ash } \\
\text { R }\end{array}$ & $\begin{array}{c}\text { ICAP-AES } \\
\text { Ash } \\
\text { D }\end{array}$ & $\begin{array}{c}\text { EDXRF } \\
\text { WC } \\
\text { R }\end{array}$ & $\begin{array}{c}\text { DCAES } \\
\text { WC } \\
\mathbf{R}\end{array}$ & $\begin{array}{c}\text { ICAP-MS } \\
\text { Ash } \\
\text { D }\end{array}$ & $\begin{array}{c}\text { DCAES } \\
\text { Ash } \\
\mathbf{R}\end{array}$ & $\begin{array}{c}\text { DCAES } \\
\text { WC } \\
\text { R }\end{array}$ & $\begin{array}{c}\text { ICAP-MS } \\
\text { Ash } \\
\text { D }\end{array}$ & $\begin{array}{c}\text { DCAES } \\
\text { Ash } \\
\text { R }\end{array}$ & $\begin{array}{l}\text { DCAES } \\
\text { WC } \\
\mathbf{R}\end{array}$ \\
\hline 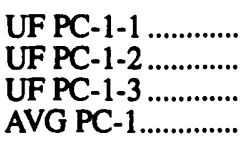 & $\begin{array}{l}18.2 \\
17.0 \\
23.9 \\
19.7\end{array}$ & $\begin{array}{l}21.9 \\
19.2 \\
20.3 \\
20.5\end{array}$ & $\begin{array}{l}19 \\
19 \\
20 \\
19\end{array}$ & $\begin{array}{l}19 \\
19 \\
19 \\
19\end{array}$ & $\begin{array}{l}35 \\
32 \\
31 \\
33\end{array}$ & $\begin{array}{l}30 \\
30 \\
40 \\
33\end{array}$ & $\begin{array}{l}\mathbf{5 . 4 5} \\
\mathbf{5 . 2 1} \\
\mathbf{5 . 3 5} \\
\mathbf{5 . 3 4}\end{array}$ & $\begin{array}{l}6.1 \\
6.3 \\
6.3 \\
6.2\end{array}$ & $\begin{array}{r}11 \\
11 \\
8 \\
10\end{array}$ & $\begin{array}{l}4.39 \\
4.29 \\
4.37 \\
4.35\end{array}$ & $\begin{array}{l}3.5 \\
3.4 \\
3.9 \\
3.6\end{array}$ & $\begin{array}{l}4 \\
4 \\
3 \\
4\end{array}$ \\
\hline $\begin{array}{l}\text { WY PC-2-1......... } \\
\text { WY PC-2-2........... } \\
\text { WY PC-2-3......... } \\
\text { AVG PC-2............ }\end{array}$ & $\begin{array}{l}11.0 \\
11.6 \\
11.2 \\
11.3\end{array}$ & $\begin{array}{r}9.7 \\
11.1 \\
11.1 \\
10.6\end{array}$ & $\begin{array}{l}10 \\
10 \\
10 \\
10\end{array}$ & $\begin{array}{l}13 \\
11 \\
12 \\
12\end{array}$ & $\begin{array}{l}26 \\
29 \\
21 \\
25\end{array}$ & $\begin{array}{l}<20 \\
<20 \\
<20 \\
-\end{array}$ & $\begin{array}{l}1.86 \\
1.82 \\
2.04 \\
1.91\end{array}$ & $\begin{array}{l}2.2 \\
2.6 \\
2.5 \\
2.4\end{array}$ & $\begin{array}{l}4 \\
2 \\
3 \\
3\end{array}$ & $\begin{array}{l}.36 \\
.36 \\
.36 \\
.36\end{array}$ & $\begin{array}{l}<.4 \\
<.4 \\
<.4 \\
-\end{array}$ & $\begin{array}{l}<2 \\
<2 \\
<2 \\
-\end{array}$ \\
\hline 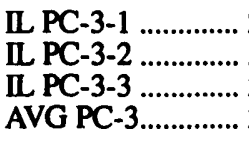 & $\begin{array}{l}218 \\
243 \\
200 \\
220\end{array}$ & $\begin{array}{c}\{94\} \\
\{112\} \\
\{115\} \\
107\end{array}$ & $\begin{array}{l}160 \\
180 \\
190 \\
180\end{array}$ & $\begin{array}{l}180 \\
210 \\
190 \\
190\end{array}$ & $\begin{array}{l}137 \\
105 \\
186 \\
140\end{array}$ & $\begin{array}{l}250 \\
260 \\
320 \\
280\end{array}$ & $\begin{array}{l}3.45 \\
3.64 \\
3.63 \\
\mathbf{3 . 5 7}\end{array}$ & $\begin{array}{l}4.7 \\
4.4 \\
5.0 \\
4.7\end{array}$ & $\begin{array}{l}8 \\
5 \\
7 \\
7\end{array}$ & $\begin{array}{l}8.10 \\
8.62 \\
8.49 \\
8.40\end{array}$ & $\begin{array}{l}8.4 \\
8.4 \\
9.7 \\
8.9\end{array}$ & $\begin{array}{r}8 \\
7 \\
12 \\
9\end{array}$ \\
\hline 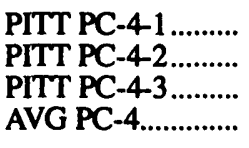 & $\begin{array}{r}8.9 \\
7.8 \\
10.5 \\
9.1\end{array}$ & $\begin{array}{l}8.5 \\
8.5 \\
8.1 \\
8.4\end{array}$ & $\begin{array}{l}8.2 \\
7.4 \\
7.7 \\
7.8\end{array}$ & $\begin{array}{c}\{14\} \\
8.1 \\
8.1 \\
8.1\end{array}$ & $\begin{array}{l}17 \\
14 \\
15 \\
15\end{array}$ & $\begin{array}{l}20 \\
30 \\
30 \\
27\end{array}$ & $\begin{array}{l}3.17 \\
3.24 \\
3.44 \\
3.28\end{array}$ & $\begin{array}{l}5.2 \\
4.0 \\
5.0 \\
4.7\end{array}$ & $\begin{array}{l}6 \\
5 \\
5 \\
5\end{array}$ & $\begin{array}{l}1.13 \\
1.22 \\
1.39 \\
1.25\end{array}$ & $\begin{array}{l}1.2 \\
1.2 \\
1.1 \\
1.2\end{array}$ & $\begin{array}{l}3 \\
<2 \\
<2 \\
(3)\end{array}$ \\
\hline $\begin{array}{l}\text { POC PC-5-1 ......... } \\
\text { POC PC-5-2 ......... } \\
\text { POC PC-5-3 ......... } \\
\text { AVG PC-5................. }\end{array}$ & $\begin{array}{l}5.74 \\
6.15 \\
7.3 \\
6.4\end{array}$ & $\begin{array}{l}4.3 \\
5.3 \\
4.7 \\
4.8\end{array}$ & $\begin{array}{l}3.9 \\
4.1 \\
3.9 \\
4.0\end{array}$ & $\begin{array}{l}5.3 \\
5.3 \\
5.3 \\
5.3\end{array}$ & $\begin{array}{l}14 \\
14 \\
15 \\
14\end{array}$ & $\begin{array}{l}20 \\
<20 \\
20 \\
-\end{array}$ & $\begin{array}{l}1.70 \\
1.80 \\
1.89 \\
1.80\end{array}$ & $\begin{array}{l}2.2 \\
2.1 \\
2.5 \\
2.3\end{array}$ & $\begin{array}{l}4 \\
3 \\
4 \\
4\end{array}$ & $\begin{array}{l}.23 \\
.27 \\
.36 \\
.29\end{array}$ & $\begin{array}{l}.46 \\
.43 \\
.49 \\
.46\end{array}$ & $\begin{array}{l}<2 \\
<2 \\
<2 \\
\end{array}$ \\
\hline $\begin{array}{l}\text { UT PC-6-1 } \\
\text { UT PC-6-2............. } \\
\text { UT PC-6-3 .............. } \\
\text { AVG PC-6............. }\end{array}$ & $\begin{array}{l}4.80 \\
7.43 \\
6.82 \\
6.35\end{array}$ & $\frac{-}{-}$ & $\frac{6.4}{6.0}$ & $\begin{array}{l}4.6 \\
5.1 \\
4.6 \\
4.8\end{array}$ & $\begin{array}{l}<2 \\
<2 \\
<2 \\
-\end{array}$ & $\bar{z}$ & $\begin{array}{l}.948 \\
.989 \\
1.05 \\
1.00\end{array}$ & $\begin{array}{l}1.5 \\
.9 \\
1.3 \\
1.2\end{array}$ & $\bar{z}$ & $\begin{array}{l}.19 \\
.24 \\
.25 \\
.23\end{array}$ & $\begin{array}{l}<.2 \\
<.2 \\
<.2 \\
-\end{array}$ & $\frac{-}{-}$ \\
\hline $\begin{array}{l}\text { WV PC-7-1......... } \\
\text { WV PC-7-2 } \\
\text { WV PC-7-3.......... } \\
\text { AVG PC-7.............. }\end{array}$ & $\begin{array}{l}14.0 \\
12.5 \\
14.0 \\
13.5\end{array}$ & $\begin{array}{l}12 \\
11 \\
12 \\
12\end{array}$ & $\begin{array}{l}13 \\
13 \\
12 \\
13\end{array}$ & $\begin{array}{l}11 \\
11 \\
11 \\
11\end{array}$ & $\begin{array}{r}9 \\
10 \\
10 \\
10\end{array}$ & $\begin{array}{l}- \\
-\end{array}$ & $\begin{array}{l}8.88 \\
9.62 \\
9.66 \\
9.39\end{array}$ & $\begin{array}{l}13 \\
11 \\
11 \\
12\end{array}$ & $\bar{z}$ & $\begin{array}{l}1.6 \\
1.7 \\
1.7 \\
1.7\end{array}$ & $\begin{array}{l}1.1 \\
<.89 \\
1.2 \\
1.1\end{array}$ & $\begin{array}{l}- \\
-\end{array}$ \\
\hline 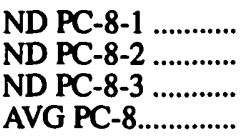 & $\begin{array}{l}\mathbf{5 . 7 1} \\
\mathbf{5 . 5} \\
\mathbf{5 . 8 6} \\
\mathbf{5 . 6 9}\end{array}$ & $\begin{array}{l}5.8 \\
5.1 \\
5.2 \\
5.4\end{array}$ & $\begin{array}{l}5.1 \\
4.7 \\
4.5 \\
4.6\end{array}$ & $\begin{array}{l}5.1 \\
4.7 \\
4.7 \\
4.8\end{array}$ & $\begin{array}{l}5 \\
4 \\
6 \\
5\end{array}$ & E & $\begin{array}{l}1.21 \\
1.14 \\
1.14 \\
1.16\end{array}$ & $\begin{array}{l}1.8 \\
1.5 \\
1.9 \\
1.7\end{array}$ & $\frac{-}{-}$ & $\begin{array}{l}.32 \\
.37 \\
.41 \\
.37\end{array}$ & $\begin{array}{l}<.44 \\
<.44 \\
<.44 \\
-\end{array}$ & - \\
\hline
\end{tabular}


Appendix 1. Comparison of the concentrations of 51 elements determined by multiple analytical techniques in 8 Argonne Premium Coal samples-Continued.

[Analyses of splits for each sample are followed by an average. - , no data. See definitions on p. 77]

\begin{tabular}{|c|c|c|c|c|c|c|c|c|c|}
\hline \multirow[b]{2}{*}{ 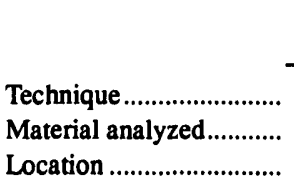 } & \multicolumn{3}{|c|}{ As (ppm) } & \multicolumn{2}{|c|}{ Se (ppm) } & \multicolumn{4}{|c|}{$\mathrm{Rb}(\mathrm{ppm})$} \\
\hline & $\begin{array}{l}\text { INAA } \\
\text { WC } \\
\mathbf{R}\end{array}$ & $\begin{array}{l}\text { ICAP-MS } \\
\text { Ash } \\
\text { D }\end{array}$ & $\begin{array}{c}\text { DCAES } \\
\text { Ash } \\
\mathbf{R}\end{array}$ & $\begin{array}{l}\text { INAA } \\
\text { WC } \\
\mathbf{R}\end{array}$ & $\begin{array}{c}\text { HGAAS } \\
\text { WC } \\
\text { D }\end{array}$ & $\begin{array}{c}\text { INAA } \\
\text { WC } \\
\mathbf{R}\end{array}$ & $\begin{array}{l}\text { ICAP-MS } \\
\text { Ash } \\
\text { D }\end{array}$ & $\begin{array}{c}\text { EDXRF } \\
\text { Ash } \\
\mathbf{R}\end{array}$ & $\begin{array}{l}\text { EDXRF } \\
\text { WC } \\
\text { R }\end{array}$ \\
\hline $\begin{array}{l}\text { UF PC-1-1 } \\
\text { UF PC-1-2 } \\
\text { UF PC-1 } \\
\text { AVG PC-1 }\end{array}$ & $\begin{array}{l}16.6 \\
17.6 \\
17.1 \\
17.1\end{array}$ & $\begin{array}{l}16.4 \\
15.9 \\
16.1 \\
16.1\end{array}$ & $\begin{array}{l}31 \\
38 \\
22 \\
30\end{array}$ & $\begin{array}{l}2.09 \\
1.88 \\
1.8 \\
1.92\end{array}$ & $\begin{array}{l}2.3 \\
2.0 \\
1.5 \\
1.9\end{array}$ & $\begin{array}{l}19.4 \\
19.0 \\
20.0 \\
19.5\end{array}$ & $\begin{array}{l}22.9 \\
21.6 \\
21.6 \\
22.0\end{array}$ & $\begin{array}{l}21.6 \\
20.8 \\
21.3 \\
21.2\end{array}$ & $\begin{array}{l}23 \\
21 \\
20 \\
21\end{array}$ \\
\hline 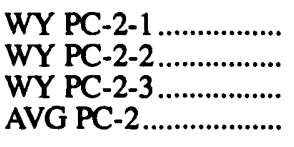 & $\begin{array}{l}3.67 \\
3.23 \\
3.75 \\
3.6\end{array}$ & $\begin{array}{l}2.8 \\
2.6 \\
1.9 \\
2.4\end{array}$ & $\begin{array}{l}<9 \\
<9 \\
<9 \\
-\end{array}$ & $\begin{array}{l}1.57 \\
1.49 \\
1.63 \\
1.56\end{array}$ & $\begin{array}{l}1.8 \\
2.8 \\
2.5 \\
2.4\end{array}$ & $\begin{array}{l}<5 \\
<5 \\
<5 \\
-\end{array}$ & $\begin{array}{l}1.80 \\
1.80 \\
1.80 \\
1.80\end{array}$ & $\begin{array}{l}3.4 \\
3.4 \\
3.7 \\
3.5\end{array}$ & $\begin{array}{l}14 \\
14 \\
11 \\
13\end{array}$ \\
\hline 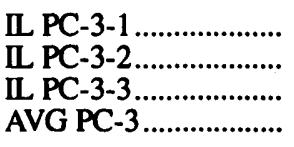 & $\begin{array}{l}4.46 \\
4.65 \\
4.90 \\
4.7\end{array}$ & $\begin{array}{l}3.6 \\
3.7 \\
4.0 \\
3.8\end{array}$ & $\begin{array}{l}<16 \\
<16 \\
<16 \\
-\end{array}$ & $\begin{array}{l}3.78 \\
4.03 \\
5.07 \\
4.29\end{array}$ & $\begin{array}{l}4.1 \\
4.0 \\
4.3 \\
4.1\end{array}$ & $\begin{array}{l}15.5 \\
17.2 \\
14.6 \\
16\end{array}$ & $\begin{array}{l}15.6 \\
16.0 \\
15.6 \\
15.7\end{array}$ & $\begin{array}{l}15 \\
15 \\
15 \\
15\end{array}$ & $\begin{array}{l}22 \\
17 \\
21 \\
20\end{array}$ \\
\hline $\begin{array}{l}\text { PITT PC-4-1 } \\
\text { PITT PC-4-2 } \ldots \ldots \ldots \ldots \ldots . . . \\
\text { PITT PC-4 } 3 \ldots \ldots \ldots \ldots \ldots \\
\text { AVG PC-4 }\end{array}$ & $\begin{array}{l}8.44 \\
8.30 \\
8.5 \\
8.42\end{array}$ & $\begin{array}{l}7.1 \\
7.6 \\
8.2 \\
7.6\end{array}$ & $\begin{array}{l}19 \\
17 \\
15 \\
17\end{array}$ & $\begin{array}{l}1.49 \\
1.60 \\
1.34 \\
1.5\end{array}$ & $\begin{array}{l}1.8 \\
1.6 \\
1.6 \\
1.7\end{array}$ & $\begin{array}{l}9.0 \\
7.2 \\
7.1 \\
7.7\end{array}$ & $\begin{array}{l}\mathbf{8 . 0 0} \\
\mathbf{8 . 0 6} \\
\mathbf{8 . 3 0} \\
\mathbf{8 . 1 2}\end{array}$ & $\begin{array}{l}9.38 \\
8.6 \\
9.20 \\
9.1\end{array}$ & $\begin{array}{l}8 \\
8 \\
8 \\
8\end{array}$ \\
\hline 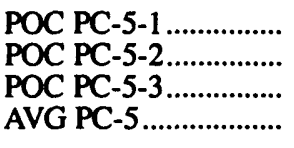 & $\begin{array}{c}10.4 \\
10.6 \\
9.89 \\
10.3\end{array}$ & $\begin{array}{c}9.33 \\
9.81 \\
10.5 \\
9.9\end{array}$ & $\begin{array}{l}18 \\
11 \\
14 \\
15\end{array}$ & $\begin{array}{l}2.3 \\
2.5 \\
2.60 \\
2.5\end{array}$ & $\begin{array}{l}2.9 \\
2.9 \\
3.1 \\
3.0\end{array}$ & $\begin{array}{l}<6 \\
<6 \\
<3 \\
-\end{array}$ & $\begin{array}{l}2.04 \\
2.11 \\
2.18 \\
2.11\end{array}$ & $\begin{array}{l}2.6 \\
2.1 \\
2.2 \\
2.3\end{array}$ & $\begin{array}{l}5 \\
4 \\
5 \\
5\end{array}$ \\
\hline 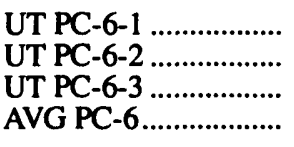 & $\begin{array}{l}.51 \\
.50 \\
.44 \\
.48\end{array}$ & $\begin{array}{l}.33 \\
<.05 \\
<.05 \\
(.33)\end{array}$ & $\begin{array}{l}<10 \\
<10 \\
<10 \\
-\end{array}$ & $\begin{array}{l}1.03 \\
1.16 \\
1.03 \\
1.08\end{array}$ & $\begin{array}{l}1.2 \\
1.3 \\
1.3 \\
1.3\end{array}$ & $\begin{array}{r}<2 \\
1.00 \\
.95 \\
.98\end{array}$ & $\begin{array}{l}1.01 \\
1.06 \\
1.10 \\
1.06\end{array}$ & $\bar{z}$ & $\begin{array}{l}3 \\
2 \\
3 \\
3\end{array}$ \\
\hline 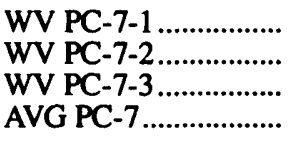 & $\begin{array}{l}5.8 \\
5.29 \\
7.40 \\
6.2\end{array}$ & $\begin{array}{l}6.4 \\
6.6 \\
7.2 \\
6.7\end{array}$ & $\begin{array}{l}<43 \\
<43 \\
<43 \\
-\end{array}$ & $\begin{array}{l}5.3 \\
5.54 \\
5.5 \\
5.4\end{array}$ & $\begin{array}{c}6.1 \\
5.6 \\
\{6.9\} \\
5.8\end{array}$ & $\begin{array}{l}29.8 \\
28.5 \\
31.2 \\
29.7\end{array}$ & $\begin{array}{l}35.0 \\
36.9 \\
36.9 \\
36.3\end{array}$ & $\begin{array}{l}42.3 \\
45.0 \\
43.4 \\
43.6\end{array}$ & $\begin{array}{l}43 \\
43 \\
40 \\
42\end{array}$ \\
\hline 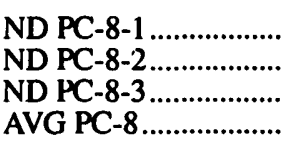 & $\begin{array}{l}2.67 \\
2.61 \\
2.61 \\
2.63\end{array}$ & $\begin{array}{l}1.6 \\
\{.70\} \\
<.1 \\
(1.6)\end{array}$ & $\begin{array}{l}<1 \\
<21 \\
<21 \\
-\end{array}$ & $\begin{array}{l}.51 \\
.61 \\
.63 \\
.58\end{array}$ & $\begin{array}{l}.60 \\
.60 \\
.60 \\
.60\end{array}$ & $\begin{array}{r}.86 \\
.99 \\
<1 \quad \\
.93\end{array}$ & $\begin{array}{l}1.37 \\
1.41 \\
1.46 \\
1.41\end{array}$ & $\bar{z}$ & $\begin{array}{l}4 \\
5 \\
3 \\
4\end{array}$ \\
\hline
\end{tabular}


Appendix 1. Comparison of the concentrations of 51 elements determined by multiple analytical techniques in 8 Argonne Premium Coal samples-Continued.

[Analyses of splits for each sample are followed by an average. -, no data. See definitions on p. 77]

\begin{tabular}{|c|c|c|c|c|c|c|c|c|c|c|c|}
\hline \multirow[b]{2}{*}{$\begin{array}{l}\text { Technique .................... } \\
\text { Material analyzed........ } \\
\text { Location ....................... }\end{array}$} & \multicolumn{6}{|c|}{$\mathrm{Sr}(\mathrm{ppm})$} & \multicolumn{5}{|c|}{$Y(p p m)$} \\
\hline & $\begin{array}{c}\text { INAA } \\
\text { WC } \\
\mathbf{R}\end{array}$ & $\begin{array}{c}\text { EDXRF } \\
\text { Ash } \\
\text { R }\end{array}$ & $\begin{array}{c}\text { ICAP-AES } \\
\text { Ash } \\
\mathbf{R}\end{array}$ & $\begin{array}{c}\text { ICAP-AES } \\
\text { Ash } \\
\text { D }\end{array}$ & $\begin{array}{c}\text { EDXRF } \\
\text { WC } \\
\text { R }\end{array}$ & $\begin{array}{c}\text { DCAES } \\
\text { Ash } \\
\text { R }\end{array}$ & $\begin{array}{c}\text { EDXRF } \\
\text { Ash } \\
\mathbf{R}\end{array}$ & $\begin{array}{c}\text { ICAP-AES } \\
\text { Ash } \\
\mathbf{R}\end{array}$ & $\begin{array}{c}\text { ICAP-AES } \\
\text { Ash } \\
\text { D }\end{array}$ & $\begin{array}{c}\text { EDXRF } \\
\text { WC } \\
\text { R }\end{array}$ & $\begin{array}{l}\text { DCAES } \\
\text { Ash } \\
\mathbf{R}\end{array}$ \\
\hline $\begin{array}{l}\text { UF PC-1-1 } \\
\text { UF PC-1-2 } \\
\text { UF PC-1 } \\
\text { AVG PC-1 } \ldots \ldots \ldots \ldots \ldots \ldots \ldots \\
\end{array}$ & $\begin{array}{l}56 \\
58 \\
33 \\
49\end{array}$ & $\begin{array}{l}59 \\
61 \\
61 \\
60\end{array}$ & $\begin{array}{l}59 \\
61 \\
58 \\
59\end{array}$ & $\begin{array}{l}58 \\
58 \\
58 \\
58\end{array}$ & $\begin{array}{l}61 \\
63 \\
61 \\
62\end{array}$ & $\begin{array}{l}66 \\
57 \\
66 \\
63\end{array}$ & $\begin{array}{l}10 \\
9.7 \\
11 \\
10\end{array}$ & $\begin{array}{l}9.3 \\
9.3 \\
9.2 \\
9.3\end{array}$ & $\begin{array}{l}8.5 \\
8.1 \\
7.6 \\
8.1\end{array}$ & $\overline{-}$ & $\begin{array}{l}6.2 \\
3.0 \\
4.9 \\
4.7\end{array}$ \\
\hline 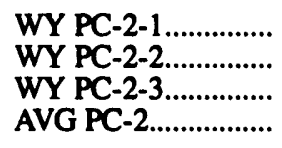 & $\begin{array}{l}263 \\
248 \\
245 \\
252\end{array}$ & $\begin{array}{l}260 \\
260 \\
260 \\
260\end{array}$ & $\begin{array}{l}\{153\} \\
\{145\} \\
\{153\} \\
150\end{array}$ & $\begin{array}{l}260 \\
260 \\
260 \\
260\end{array}$ & $\begin{array}{l}292 \\
300 \\
291 \\
294\end{array}$ & $\begin{array}{l}170 \\
240 \\
260 \\
220\end{array}$ & $\begin{array}{l}3.4 \\
3.6 \\
3.7 \\
3.6\end{array}$ & $\begin{array}{l}3.9 \\
3.7 \\
3.7 \\
3.8\end{array}$ & $\begin{array}{l}3.6 \\
3.6 \\
3.7 \\
3.6\end{array}$ & $\begin{array}{l}- \\
-\end{array}$ & $\begin{array}{l}2.4 \\
3.1 \\
3.6 \\
3.0\end{array}$ \\
\hline 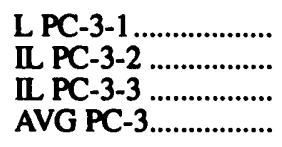 & $\begin{array}{l}42 \\
36 \\
40 \\
39\end{array}$ & $\begin{array}{l}30.5 \\
28.8 \\
30.5 \\
29.9\end{array}$ & $\begin{array}{l}29 \\
29 \\
29 \\
29\end{array}$ & $\begin{array}{l}31 \\
32 \\
31 \\
31\end{array}$ & $\begin{array}{l}33 \\
30 \\
35 \\
33\end{array}$ & $\begin{array}{l}40 \\
37 \\
44 \\
40\end{array}$ & $\begin{array}{l}4.9 \\
3.2 \\
4.2 \\
4.1\end{array}$ & $\begin{array}{l}4.2 \\
4.2 \\
4.2 \\
4.2\end{array}$ & $\begin{array}{l}4.2 \\
4.2 \\
3.7 \\
4.0\end{array}$ & $\begin{array}{l}- \\
-\end{array}$ & $\begin{array}{l}4.4 \\
4.7 \\
5.2 \\
4.7\end{array}$ \\
\hline $\begin{array}{l}\text { PITT PC-41 } \\
\text { PITT PC-42............ } \\
\text { PITT PC-4-3.................. } \\
\text { AVG PC-4 }\end{array}$ & $\begin{array}{l}58 \\
61 \\
65 \\
61\end{array}$ & $\begin{array}{l}70 \\
68 \\
65 \\
68\end{array}$ & $\begin{array}{l}64 \\
64 \\
63 \\
64\end{array}$ & $\begin{array}{l}64 \\
64 \\
63 \\
64\end{array}$ & $\begin{array}{l}59 \\
61 \\
69 \\
63\end{array}$ & $\begin{array}{r}88 \\
83 \\
100 \\
91\end{array}$ & $\begin{array}{l}5.1 \\
5.1 \\
4.4 \\
4.9\end{array}$ & $\begin{array}{l}4.3 \\
4.2 \\
4.2 \\
4.3\end{array}$ & $\begin{array}{l}4.0 \\
3.9 \\
4.0 \\
4.0\end{array}$ & $\bar{z}$ & $\begin{array}{l}2.8 \\
3.3 \\
3.0 \\
3.1\end{array}$ \\
\hline 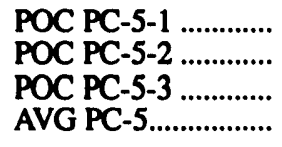 & $\begin{array}{l}97 \\
116 \\
101 \\
105\end{array}$ & $\begin{array}{l}110 \\
110 \\
110 \\
110\end{array}$ & $\begin{array}{l}85 \\
85 \\
85 \\
85\end{array}$ & $\begin{array}{l}110 \\
110 \\
110 \\
110\end{array}$ & $\begin{array}{l}86 \\
77 \\
93 \\
85\end{array}$ & $\begin{array}{l}110 \\
100 \\
120 \\
110\end{array}$ & $\begin{array}{l}7.10 \\
6.68 \\
6.89 \\
6.89\end{array}$ & $\begin{array}{l}6.4 \\
6.4 \\
5.8 \\
6.2\end{array}$ & $\begin{array}{l}5.8 \\
5.8 \\
5.8 \\
5.8\end{array}$ & $\frac{-}{-}$ & $\begin{array}{l}4.6 \\
4.3 \\
4.9 \\
4.6\end{array}$ \\
\hline 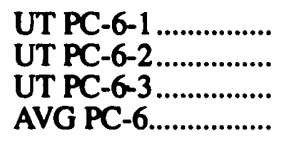 & $\begin{array}{l}71 \\
68 \\
70 \\
70\end{array}$ & $\begin{array}{l}- \\
-\end{array}$ & $\begin{array}{l}60 \\
59 \\
\frac{60}{60}\end{array}$ & $\begin{array}{l}60 \\
60 \\
60 \\
60\end{array}$ & $\begin{array}{l}58 \\
65 \\
66 \\
63\end{array}$ & $\begin{array}{l}83 \\
92 \\
92 \\
89\end{array}$ & $\begin{array}{l}- \\
-\end{array}$ & $\begin{array}{l}1.8 \\
2.1 \\
\frac{2.0}{2.0}\end{array}$ & $\begin{array}{l}2.1 \\
2.0 \\
2.0 \\
2.0\end{array}$ & $\begin{array}{l}2 \\
<2 \\
<2 \\
(2)\end{array}$ & $\begin{array}{l}1.9 \\
1.9 \\
1.6 \\
1.8\end{array}$ \\
\hline 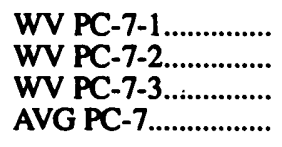 & $\begin{array}{l}64 \\
59 \\
58 \\
60\end{array}$ & $\begin{array}{l}76.2 \\
78.0 \\
79.7 \\
78.0\end{array}$ & $\begin{array}{l}49 \\
47 \\
51 \\
49\end{array}$ & $\begin{array}{l}62 \\
62 \\
62 \\
62\end{array}$ & $\begin{array}{l}87 \\
87 \\
83 \\
86\end{array}$ & $\begin{array}{l}76 \\
62 \\
72 \\
70\end{array}$ & $\begin{array}{l}\{21.4\} \\
\{19\} \\
\{22.9\} \\
21.2\end{array}$ & $\begin{array}{l}11 \\
11 \\
11 \\
11\end{array}$ & $\begin{array}{l}12 \\
13 \\
12 \\
12\end{array}$ & $\begin{array}{l}19 \\
20 \\
17 \\
19\end{array}$ & $\begin{array}{c}9.7 \\
10 \\
7.6 \\
9.1\end{array}$ \\
\hline 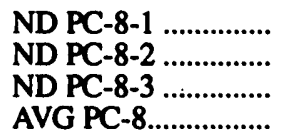 & $\begin{array}{l}\mathbf{6 2 8} \\
\mathbf{5 8 0} \\
\mathbf{5 8 3} \\
\mathbf{5 9 7}\end{array}$ & $\begin{array}{l}640 \\
640 \\
630 \\
640\end{array}$ & $\begin{array}{l}510 \\
500 \\
500 \\
500\end{array}$ & $\begin{array}{l}490 \\
490 \\
490 \\
490\end{array}$ & $\begin{array}{l}800 \\
800 \\
750 \\
780\end{array}$ & $\begin{array}{l}590 \\
600 \\
690 \\
630\end{array}$ & $\overline{-}$ & $\begin{array}{l}1.9 \\
1.8 \\
\frac{1.8}{1.8}\end{array}$ & $\begin{array}{l}2.2 \\
2.3 \\
2.2 \\
2.2\end{array}$ & $\begin{array}{l}<2 \\
<2 \\
<\end{array}$ & $\begin{array}{l}2.3 \\
2.6 \\
2.4 \\
2.4\end{array}$ \\
\hline
\end{tabular}


Appendix 1. Comparison of the concentrations of 51 elements determined by multiple analytical techniques in 8 Argonne Premium Coal samples-Continued.

[Analyses of splits for each sample are followed by an average. -, no data. See definitions on p. 77]

\begin{tabular}{|c|c|c|c|c|c|c|c|c|c|c|c|}
\hline \multirow[b]{2}{*}{ 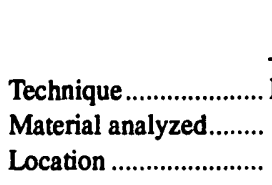 } & \multicolumn{5}{|c|}{$\mathrm{Zr}$ (ppm) } & \multicolumn{4}{|c|}{$\mathrm{Nb}$ (ppm) } & \multicolumn{2}{|c|}{ Mo (ppm) } \\
\hline & $\begin{array}{c}\text { ICAP-AES } \\
\text { Ash } \\
\text { D }\end{array}$ & $\begin{array}{c}\text { EDXRF } \\
\text { Ash } \\
\text { R }\end{array}$ & $\begin{array}{c}\text { EDXRF } \\
\text { WC } \\
\text { R }\end{array}$ & $\begin{array}{c}\text { DCAES } \\
\text { Ash } \\
\text { R }\end{array}$ & $\begin{array}{c}\text { DCAES } \\
\text { WC } \\
\text { R }\end{array}$ & $\begin{array}{c}\text { ICAP-MS } \\
\text { Ash } \\
\text { D }\end{array}$ & $\begin{array}{c}\text { EDXRF } \\
\text { Ash } \\
\text { R }\end{array}$ & $\begin{array}{c}\text { EDXRF } \\
\text { WC } \\
\mathbf{R}\end{array}$ & $\begin{array}{c}\text { DCAES } \\
\text { Ash } \\
\mathbf{R}\end{array}$ & $\begin{array}{c}\text { ICAP-MS } \\
\text { Ash } \\
\text { D }\end{array}$ & $\begin{array}{l}\text { DCAES } \\
\text { Ash } \\
\text { R }\end{array}$ \\
\hline $\begin{array}{l}\text { UF PC-1-1 } \\
\text { UF PC-1 } 2 \ldots \ldots \ldots \ldots \ldots \\
\text { UF PC-1-3.................... } \\
\text { AVG PC-1 }\end{array}$ & $\begin{array}{l}24 \\
24 \\
25 \\
24\end{array}$ & $\begin{array}{l}27.7 \\
26.5 \\
27.7 \\
27.3\end{array}$ & $\begin{array}{l}24 \\
22 \\
24 \\
23\end{array}$ & $\begin{array}{l}13 \\
7.4 \\
12 \\
11\end{array}$ & $\begin{array}{l}36 \\
29 \\
34 \\
33\end{array}$ & $\begin{array}{l}2.6 \\
2.3 \\
2.4 \\
2.4\end{array}$ & $\begin{array}{l}2.7 \\
2.2 \\
2.7 \\
2.5\end{array}$ & $\overline{-}$ & $\begin{array}{l}1.6 \\
1.3 \\
2.0 \\
1.7\end{array}$ & $\begin{array}{l}3.02 \\
2.24 \\
2.23 \\
2.50\end{array}$ & $\begin{array}{l}1.6 \\
1.3 \\
1.6 \\
1.5\end{array}$ \\
\hline $\begin{array}{l}\text { WY PC-2-1 } \\
\text { WY PC-2-2 } \ldots \ldots \ldots \ldots \ldots \\
\text { WY PC-2-3 ................... } \\
\text { AVG PC-2 }\end{array}$ & $\begin{array}{l}18 \\
19 \\
20 \\
19\end{array}$ & $\begin{array}{l}22.1 \\
23.4 \\
22.5 \\
22.7\end{array}$ & $\begin{array}{l}19 \\
21 \\
17 \\
19\end{array}$ & $\begin{array}{l}12 \\
17 \\
21 \\
17\end{array}$ & $\begin{array}{l}<20 \\
<20 \\
<20 \\
-\end{array}$ & $\begin{array}{l}1.4 \\
1.3 \\
1.5 \\
1.4\end{array}$ & $\begin{array}{l}1.2 \\
1.0 \\
.85 \\
1.0\end{array}$ & $\overline{-}$ & $\begin{array}{l}1.2 \\
1.3 \\
1.8 \\
1.4\end{array}$ & $\begin{array}{l}.52 \\
.49 \\
.54 \\
.52\end{array}$ & $\begin{array}{l}.65 \\
.66 \\
.70 \\
.67\end{array}$ \\
\hline 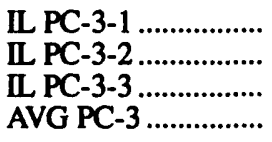 & $\begin{array}{l}28 \\
23 \\
19 \\
23\end{array}$ & $\begin{array}{l}23.7 \\
21.1 \\
22.0 \\
22.3\end{array}$ & $\begin{array}{l}24 \\
22 \\
24 \\
23\end{array}$ & $\begin{array}{l}14 \\
16 \\
23 \\
17\end{array}$ & $\begin{array}{l}22 \\
25 \\
16 \\
21\end{array}$ & $\begin{array}{l}1.9 \\
2.3 \\
2.4 \\
2.2\end{array}$ & $\begin{array}{r}1.9 \\
<1.6 \\
2.3 \\
2.1\end{array}$ & - & $\begin{array}{c}19 \\
2.3 \\
3.2 \\
2.5\end{array}$ & $\begin{array}{l}7.24 \\
5.57 \\
6.06 \\
6.23\end{array}$ & $\begin{array}{l}5.5 \\
4.9 \\
5.2 \\
5.2\end{array}$ \\
\hline $\begin{array}{l}\text { PITT PC-4-1 } \\
\text { PITT PC-42 } \\
\text { PITT PC-4 } 3 \ldots \ldots \ldots \\
\text { AVG PC-4 }\end{array}$ & $\begin{array}{l}18 \\
18 \\
18 \\
18\end{array}$ & $\begin{array}{l}20.7 \\
21.2 \\
19.8 \\
20.5\end{array}$ & $\begin{array}{l}15 \\
17 \\
18 \\
17\end{array}$ & $\begin{array}{l}10 \\
15 \\
11 \\
12\end{array}$ & $\begin{array}{l}23 \\
21 \\
28 \\
24\end{array}$ & $\begin{array}{l}1.6 \\
1.7 \\
1.8 \\
1.7\end{array}$ & $\begin{array}{l}2.0 \\
1.8 \\
1.8 \\
1.9\end{array}$ & - & $\begin{array}{l}1.7 \\
2.0 \\
1.7 \\
1.8\end{array}$ & $\begin{array}{l}.71 \\
.73 \\
.77 \\
.74\end{array}$ & $\begin{array}{l}.86 \\
.70 \\
.83 \\
.80\end{array}$ \\
\hline 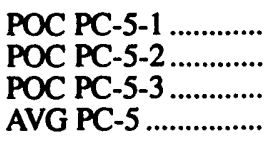 & $\begin{array}{l}17 \\
16 \\
15 \\
16\end{array}$ & $\begin{array}{l}17.0 \\
16.7 \\
17.0 \\
16.9\end{array}$ & $\begin{array}{r}10 \\
8 \\
11 \\
10\end{array}$ & $\begin{array}{l}13 \\
11 \\
12 \\
12\end{array}$ & $\begin{array}{l}25 \\
34 \\
32 \\
30\end{array}$ & $\begin{array}{l}1.0 \\
1.1 \\
1.3 \\
1.1\end{array}$ & $\begin{array}{l}.85 \\
.85 \\
.85 \\
.85\end{array}$ & - & $\begin{array}{l}1.3 \\
.74 \\
1.2 \\
1.1\end{array}$ & $\begin{array}{l}2.61 \\
2.65 \\
2.85 \\
2.67\end{array}$ & $\begin{array}{l}2.0 \\
2.2 \\
2.4 \\
2.2\end{array}$ \\
\hline $\begin{array}{l}\text { UT PC-6-1............ } \\
\text { UT PC-6-2................ } \\
\text { UT PC-6-3................ } \\
\text { AVG PC-6 }\end{array}$ & $\begin{array}{l}17 \\
18 \\
17 \\
17\end{array}$ & z & $\begin{array}{l}20 \\
17 \\
16 \\
18\end{array}$ & $\begin{array}{c}12 \\
13 \\
9.2 \\
11\end{array}$ & $\begin{array}{l}- \\
- \\
-\end{array}$ & $\begin{array}{l}.51 \\
.55 \\
.64 \\
.57\end{array}$ & $\begin{array}{l}- \\
-\end{array}$ & $\begin{array}{l}<10 \\
<10 \\
<10 \\
-\end{array}$ & $\begin{array}{l}.46 \\
.51 \\
.55 \\
.51\end{array}$ & $\begin{array}{l}.41 \\
.41 \\
.45 \\
.42\end{array}$ & $\begin{array}{l}.55 \\
.39 \\
.51 \\
.48\end{array}$ \\
\hline 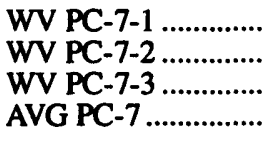 & $\begin{array}{l}66 \\
74 \\
68 \\
69\end{array}$ & $\begin{array}{l}80.0 \\
79.8 \\
81.6 \\
80.5\end{array}$ & $\begin{array}{l}106 \\
102 \\
101 \\
103\end{array}$ & $\begin{array}{l}47 \\
29 \\
27 \\
34\end{array}$ & $\begin{array}{l}- \\
- \\
-\end{array}$ & $\begin{array}{l}5.6 \\
6.0 \\
6.6 \\
6.1\end{array}$ & $\begin{array}{l}7.8 \\
8.3 \\
8.9 \\
8.3\end{array}$ & $\begin{array}{r}13 \\
<10 \\
13 \\
13\end{array}$ & $\begin{array}{l}2.5 \\
3.7 \\
4.5 \\
3.6\end{array}$ & $\begin{array}{l}1.2 \\
1.3 \\
1.3 \\
1.3\end{array}$ & $\begin{array}{l}1.3 \\
1.6 \\
1.2 \\
1.4\end{array}$ \\
\hline 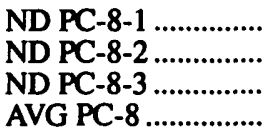 & $\begin{array}{l}11 \\
13 \\
12 \\
12\end{array}$ & $\begin{array}{l}6.5 \\
7.0 \\
4.5 \\
6.5\end{array}$ & $\begin{array}{l}20 \\
19 \\
17 \\
18\end{array}$ & $\begin{array}{l}12 \\
12 \\
13 \\
13\end{array}$ & $\begin{array}{l}- \\
-\end{array}$ & $\begin{array}{l}.74 \\
.80 \\
.84 \\
.79\end{array}$ & $\begin{array}{l}<1 \\
<1 \\
<1 \\
-\end{array}$ & $\begin{array}{l}<10 \\
<10 \\
<10 \\
-\end{array}$ & $\begin{array}{l}.63 \\
.51 \\
.61 \\
.58\end{array}$ & $\begin{array}{l}.39 \\
.42 \\
.44 \\
.42\end{array}$ & $\begin{array}{l}.82 \\
.78 \\
.83 \\
.81\end{array}$ \\
\hline
\end{tabular}


Appendix 1. Comparison of the concentrations of 51 elements determined by multiple analytical techniques in 8 Argonne Premium Coal samples-Continued.

[Analyses of splits for each sample are followed by an average. —, no data. See definitions on p. 77]

\begin{tabular}{|c|c|c|c|c|c|c|c|c|c|c|}
\hline \multirow[b]{2}{*}{$\begin{array}{l}\text { Technique .................. } \\
\text { Material analyzed........ } \\
\text { Location ....................... }\end{array}$} & \multicolumn{2}{|c|}{ Ag (ppm) } & \multicolumn{2}{|c|}{$\mathrm{Cd}(\mathrm{ppm})$} & \multicolumn{2}{|c|}{ Sn (ppm) } & \multicolumn{2}{|c|}{ Sb (ppm) } & \multicolumn{2}{|c|}{ Cs (ppm) } \\
\hline & $\begin{array}{c}\text { ICAP-MS } \\
\text { Ash } \\
\text { D }\end{array}$ & $\begin{array}{c}\text { DCARS } \\
\text { Ash } \\
\text { R }\end{array}$ & $\begin{array}{c}\text { ICAP-MS } \\
\text { Ash } \\
\text { D }\end{array}$ & $\begin{array}{c}\text { GFAAS } \\
\text { Ash } \\
\mathbf{R}\end{array}$ & $\begin{array}{c}\text { ICAP-MS } \\
\text { Ash } \\
\text { D }\end{array}$ & $\begin{array}{c}\text { DCAES } \\
\text { Ash } \\
\text { R }\end{array}$ & $\begin{array}{c}\text { INAA } \\
\text { WC } \\
\mathbf{R}\end{array}$ & $\begin{array}{c}\text { ICAP-MS } \\
\text { Ash } \\
\text { D }\end{array}$ & $\begin{array}{c}\text { INAA } \\
\text { WC } \\
\mathbf{R}\end{array}$ & $\begin{array}{c}\text { ICAP-MS } \\
\text { Ash } \\
\text { D }\end{array}$ \\
\hline 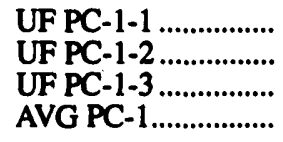 & $\begin{array}{r}0.36 \\
.40 \\
.62 \\
.46\end{array}$ & $\begin{array}{r}0.19 \\
.20 \\
.22 \\
.21\end{array}$ & $\begin{array}{r}0.14 \\
.22 \\
.14 \\
.17\end{array}$ & $\begin{array}{r}0.072 \\
.069 \\
.073 \\
.071\end{array}$ & $\begin{array}{l}0.96 \\
.97 \\
.95 \\
.96\end{array}$ & $\begin{array}{l}1.76 \\
1.62 \\
1.62 \\
1.67\end{array}$ & $\begin{array}{c}\mathbf{0 . 5 5 8} \\
.50 \\
.535 \\
.531\end{array}$ & $\begin{array}{r}0.51 \\
.46 \\
.50 \\
.49\end{array}$ & $\begin{array}{l}1.48 \\
1.52 \\
1.56 \\
1.52\end{array}$ & $\begin{array}{l}1.89 \\
1.89 \\
1.89 \\
1.89\end{array}$ \\
\hline 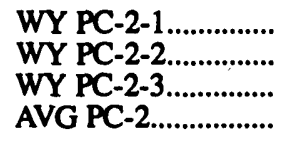 & $\begin{array}{l}.17 \\
.20 \\
.33 \\
.23\end{array}$ & $\begin{array}{l}.055 \\
.072 \\
.075 \\
.067\end{array}$ & $\begin{array}{l}.10 \\
.11 \\
.15 \\
.12\end{array}$ & $\begin{array}{l}.094 \\
.094 \\
.094 \\
.094\end{array}$ & $\begin{array}{l}.32 \\
.32 \\
.32 \\
.32\end{array}$ & $\begin{array}{l}.544 \\
.85 \\
1.2 \\
.86\end{array}$ & $\begin{array}{l}.180 \\
.203 \\
.191 \\
.191\end{array}$ & $\begin{array}{l}.15 \\
.15 \\
.18 \\
.16\end{array}$ & $\begin{array}{l}.180 \\
.203 \\
.191 \\
.191\end{array}$ & $\begin{array}{l}.19 \\
.20 \\
.19 \\
.19\end{array}$ \\
\hline 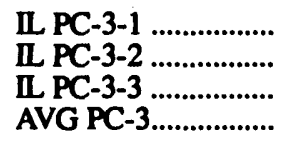 & $\begin{array}{l}.44 \\
.62 \\
.79 \\
.62\end{array}$ & $\begin{array}{l}.356 \\
.421 \\
.324 \\
.367\end{array}$ & $\begin{array}{l}.67 \\
.76 \\
.94 \\
.79\end{array}$ & $\begin{array}{l}.60 \\
.65 \\
.57 \\
.61\end{array}$ & $\begin{array}{l}.70 \\
.75 \\
.70 \\
.72\end{array}$ & $\begin{array}{l}1.6 \\
2.4 \\
3.2 \\
2.4\end{array}$ & $\begin{array}{l}.848 \\
.913 \\
.870 \\
.877\end{array}$ & $\begin{array}{l}.73 \\
.81 \\
.84 \\
.79\end{array}$ & $\begin{array}{l}.848 \\
.913 \\
.870 \\
.877\end{array}$ & $\begin{array}{l}1.4 \\
1.4 \\
1.4 \\
1.4\end{array}$ \\
\hline 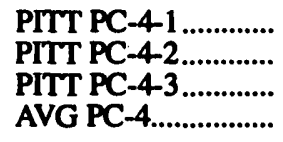 & $\begin{array}{l}.18 \\
.29 \\
.44 \\
.31\end{array}$ & $\begin{array}{l}.087 \\
.086 \\
.092 \\
.088\end{array}$ & $\begin{array}{l}.10 \\
.092 \\
.13 \\
.11\end{array}$ & $\begin{array}{l}.059 \\
.058 \\
.063 \\
.061\end{array}$ & $\begin{array}{l}.57 \\
.57 \\
.58 \\
.57\end{array}$ & $\begin{array}{l}1.7 \\
1.0 \\
1.2 \\
1.3\end{array}$ & $\begin{array}{l}.239 \\
.240 \\
.221 \\
.233\end{array}$ & $\begin{array}{l}.18 \\
.20 \\
.21 \\
.20\end{array}$ & $\begin{array}{l}.737 \\
.69 \\
.67 \\
.70\end{array}$ & $\begin{array}{l}.80 \\
.81 \\
.80 \\
.80\end{array}$ \\
\hline 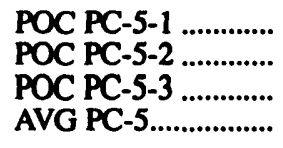 & $\begin{array}{l}.14 \\
.22 \\
.32 \\
.23\end{array}$ & $\begin{array}{l}.095 \\
.095 \\
.106 \\
.099\end{array}$ & $\begin{array}{l}\{.034\} \\
.053 \\
.090 \\
.072\end{array}$ & $\begin{array}{l}.085 \\
.074 \\
.074 \\
.078\end{array}$ & $\begin{array}{l}.37 \\
.37 \\
.38 \\
.37\end{array}$ & $\begin{array}{r}148 \\
29 \\
38 \\
72\end{array}$ & $\begin{array}{l}.625 \\
.458 \\
.535 \\
.539\end{array}$ & $\begin{array}{l}.29 \\
.29 \\
.32 \\
.27\end{array}$ & $\begin{array}{l}.256 \\
.283 \\
.247 \\
.262\end{array}$ & $\begin{array}{l}.23 \\
.23 \\
.22 \\
.22\end{array}$ \\
\hline 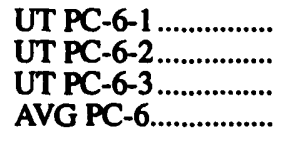 & $\begin{array}{l}.097 \\
.17 \\
.19 \\
.15\end{array}$ & $\begin{array}{l}.55 \\
.41 \\
.44 \\
.47\end{array}$ & $\begin{array}{l}.064 \\
.078 \\
.087 \\
.077\end{array}$ & $\begin{array}{l}.060 \\
.060 \\
.060\end{array}$ & $\begin{array}{l}.17 \\
.17 \\
.16 \\
.16\end{array}$ & $\begin{array}{l}.40 \\
.28 \\
.43 \\
.37\end{array}$ & $\begin{array}{l}.118 \\
.098 \\
.106 \\
.107\end{array}$ & $\begin{array}{l}.087 \\
.087 \\
.092 \\
.089\end{array}$ & $\begin{array}{l}.123 \\
.148 \\
.119 \\
.130\end{array}$ & $\begin{array}{l}.14 \\
.14 \\
.14 \\
.14\end{array}$ \\
\hline 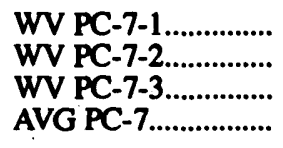 & $\begin{array}{l}.70 \\
1.2 \\
1.8 \\
1.2\end{array}$ & $\begin{array}{l}.50 \\
.43 \\
.43 \\
.45\end{array}$ & $\begin{array}{l}.050 \\
.044 \\
.072 \\
.055\end{array}$ & $\begin{array}{l}.078 \\
.072 \\
.085 \\
.078\end{array}$ & $\begin{array}{l}1.7 \\
1.7 \\
1.7 \\
1.7\end{array}$ & $\begin{array}{l}2.13 \\
1.61 \\
1.94 \\
1.9\end{array}$ & $\begin{array}{l}.521 \\
.540 \\
.502 \\
.521\end{array}$ & $\begin{array}{l}.52 \\
.54 \\
.62 \\
.56\end{array}$ & $\begin{array}{l}1.88 \\
1.87 \\
1.84 \\
1.86\end{array}$ & $\begin{array}{l}2.33 \\
2.33 \\
2.33 \\
2.33\end{array}$ \\
\hline 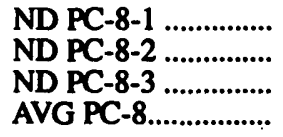 & $\begin{array}{l}.095 \\
.15 \\
.22 \\
.16\end{array}$ & $\begin{array}{c}<.0095 \\
<.0095 \\
<.0095 \\
-\end{array}$ & $\begin{array}{l}.029 \\
.043 \\
.049 \\
.040\end{array}$ & $\begin{array}{l}.048 \\
.044 \\
.046 \\
.046\end{array}$ & $\begin{array}{l}.28 \\
.28 \\
.56 \\
.38\end{array}$ & $\begin{array}{l}<.5 \\
<.5 \\
1.23 \\
(1.23)\end{array}$ & $\begin{array}{l}.148 \\
.155 \\
.158 \\
.153\end{array}$ & $\begin{array}{l}.13 \\
.14 \\
.19 \\
.16\end{array}$ & $\begin{array}{l}.072 \\
.097 \\
.089 \\
.086\end{array}$ & $\begin{array}{l}.10 \\
.095 \\
.10 \\
.10\end{array}$ \\
\hline
\end{tabular}


Appendix 1. Comparison of the concentrations of 51 elements determined by multiple analytical techniques in 8 Argonne Premium Coal samples-Continued.

[Analyses of splits for each sample are followed by an average. —, no data. See definitions on p. 77]

\begin{tabular}{|c|c|c|c|c|c|c|c|c|c|c|c|c|}
\hline \multirow[b]{2}{*}{$\begin{array}{l}\text { Technique ............... } \\
\text { Material analyzed... } \\
\text { Location ......................... }\end{array}$} & \multicolumn{7}{|c|}{$\mathrm{Ba}(\mathrm{ppm})$} & \multicolumn{5}{|c|}{$\mathrm{La}$ (ppm) } \\
\hline & $\begin{array}{c}\text { INAA } \\
\mathbf{W C} \\
\mathbf{R}\end{array}$ & $\begin{array}{c}\text { EDXRF } \\
\text { Ash } \\
\text { R }\end{array}$ & $\begin{array}{c}\text { ICAP-AES } \\
\text { Ash } \\
\mathbf{R}\end{array}$ & $\begin{array}{l}\text { ICAP-AES } \\
\text { Ash } \\
\text { D }\end{array}$ & $\begin{array}{c}\text { EDXRF } \\
\text { WC } \\
\mathbf{R}\end{array}$ & $\begin{array}{c}\text { DCAES } \\
\text { Ash } \\
\text { R }\end{array}$ & $\begin{array}{c}\text { DCAES } \\
\text { WC } \\
\text { R }\end{array}$ & $\begin{array}{c}\text { INAA } \\
\text { WC } \\
\mathbf{R}\end{array}$ & $\begin{array}{l}\text { ICAP-MS } \\
\text { Ash } \\
\text { D }\end{array}$ & $\begin{array}{c}\text { EDXRF } \\
\text { Ash } \\
\mathbf{R}\end{array}$ & $\begin{array}{l}\text { EDXRF } \\
\text { WC } \\
\text { R }\end{array}$ & $\begin{array}{l}\text { DCAES } \\
\text { Ash } \\
\mathbf{R}\end{array}$ \\
\hline $\begin{array}{l}\text { UF PC-1-1......... } \\
\text { UF PC-1 } 2 \ldots \ldots \ldots \ldots \\
\text { UF PC-1 } 3 \ldots \ldots \ldots \ldots \\
\text { AVG PC-1 ................ }\end{array}$ & $\begin{array}{l}52 \\
68 \\
63 \\
61\end{array}$ & $\begin{array}{l}51 \\
54.7 \\
50 \\
52\end{array}$ & $\begin{array}{l}\mathbf{5 4} \\
\mathbf{5 5} \\
\mathbf{5 7} \\
\mathbf{5 5}\end{array}$ & $\begin{array}{l}53 \\
51 \\
63 \\
56\end{array}$ & $\begin{array}{l}54 \\
68 \\
59 \\
60\end{array}$ & $\begin{array}{l}40 \\
43 \\
39 \\
41\end{array}$ & $\begin{array}{l}88 \\
72 \\
84 \\
81\end{array}$ & $\begin{array}{l}10.0 \\
10.0 \\
10.3 \\
10.1\end{array}$ & $\begin{array}{l}6.8 \\
8.1 \\
8.1 \\
7.7\end{array}$ & $\begin{array}{l}7.0 \\
8.1 \\
9.5 \\
8.2\end{array}$ & $\begin{array}{r}31 \\
9 \\
9 \\
16\end{array}$ & $\begin{array}{l}8.6 \\
5.3 \\
6.7 \\
6.9\end{array}$ \\
\hline $\begin{array}{l}\text { WY PC-2-1 ......... } \\
\text { WY PC-2-2 ......... } \\
\text { WY PC-2-3 ......... } \\
\text { AVG PC-2 .......... }\end{array}$ & $\begin{array}{l}324 \\
318 \\
297 \\
310\end{array}$ & $\begin{array}{l}270 \\
280 \\
260 \\
270\end{array}$ & $\begin{array}{c}\{15\} \\
\{15\} \\
\{14\} \\
15\end{array}$ & $\begin{array}{l}280 \\
290 \\
310 \\
290\end{array}$ & $\begin{array}{l}404 \\
407 \\
415 \\
410\end{array}$ & $\begin{array}{l}290 \\
310 \\
360 \\
320\end{array}$ & $\begin{array}{l}200 \\
260 \\
300 \\
250\end{array}$ & $\begin{array}{l}\mathbf{5 . 3 2} \\
\mathbf{5 . 3 4} \\
\mathbf{5 . 3 8} \\
\mathbf{5 . 3 5}\end{array}$ & $\begin{array}{l}4.2 \\
3.4 \\
4.3 \\
4.0\end{array}$ & $\begin{array}{l}<3 \\
<3 \\
<3 \\
\end{array}$ & $\begin{array}{r}4 \\
4 \\
11 \\
6\end{array}$ & $\begin{array}{l}4.8 \\
6.5 \\
7.1 \\
6.1\end{array}$ \\
\hline $\begin{array}{l}\text { IL PC-3-1 } \\
\text { IL PC-3-2 } \\
\text { IL PC-3-3............... } \\
\text { AVG PC-3 ............ }\end{array}$ & $\begin{array}{l}94 \\
91 \\
96 \\
94\end{array}$ & $\begin{array}{l}75.3 \\
74.5 \\
73.7 \\
74.5\end{array}$ & $\begin{array}{l}68 \\
87 \\
87 \\
81\end{array}$ & $\begin{array}{l}83 \\
77 \\
86 \\
82\end{array}$ & $\begin{array}{l}112 \\
122 \\
129 \\
121\end{array}$ & $\begin{array}{l}51 \\
53 \\
76 \\
60\end{array}$ & $\begin{array}{r}140 \\
120 \\
92 \\
120\end{array}$ & $\begin{array}{l}6.11 \\
6.10 \\
6.09 \\
6.10\end{array}$ & $\begin{array}{l}6.5 \\
6.5 \\
4.8 \\
5.9\end{array}$ & $\begin{array}{l}<5 \\
<5 \\
<5 \\
-\end{array}$ & $\begin{array}{l}16 \\
15 \\
15 \\
15\end{array}$ & $\begin{array}{c}8.7 \\
8.9 \\
10 \\
9.3\end{array}$ \\
\hline $\begin{array}{l}\text { PITT PC-4-1 ....... } \\
\text { PITT PC-42 } \ldots . . . \\
\text { PITT PC-4-3 ....... } \\
\text { AVG PC-4 .......... }\end{array}$ & $\begin{array}{l}44 \\
51 \\
44 \\
47\end{array}$ & $\begin{array}{l}34.0 \\
37.7 \\
35.4 \\
35.7\end{array}$ & $\begin{array}{l}42 \\
41 \\
39 \\
41\end{array}$ & $\begin{array}{l}39 \\
39 \\
38 \\
39\end{array}$ & $\begin{array}{l}46 \\
22 \\
19 \\
29\end{array}$ & $\begin{array}{l}36 \\
34 \\
45 \\
38\end{array}$ & $\begin{array}{l}66 \\
72 \\
60 \\
66\end{array}$ & $\begin{array}{l}6.19 \\
6.15 \\
6.11 \\
6.15\end{array}$ & $\begin{array}{l}4.6 \\
4.6 \\
4.6 \\
4.6\end{array}$ & $\begin{array}{l}<3 \\
4.6 \\
4.2 \\
4.4\end{array}$ & $\begin{array}{r}23 \\
1 \\
2 \\
9\end{array}$ & $\begin{array}{l}5.5 \\
6.1 \\
5.7 \\
5.8\end{array}$ \\
\hline $\begin{array}{l}\text { POC PC-5-1 ....... } \\
\text { POC PC-5-2 ........ } \\
\text { POC PC-5-3 ........ } \\
\text { AVG PC-5 ........... }\end{array}$ & $\begin{array}{l}197 \\
203 \\
193 \\
198\end{array}$ & $\begin{array}{l}170 \\
190 \\
180 \\
180\end{array}$ & 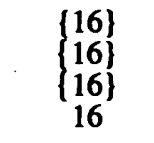 & $\begin{array}{l}220 \\
200 \\
200 \\
210\end{array}$ & $\begin{array}{l}134 \\
124 \\
164 \\
140\end{array}$ & $\begin{array}{l}190 \\
190 \\
260 \\
210\end{array}$ & $\begin{array}{l}400 \\
460 \\
500 \\
450\end{array}$ & $\begin{array}{l}6.78 \\
6.77 \\
6.73 \\
6.76\end{array}$ & $\begin{array}{l}\mathbf{5 . 9 8} \\
\mathbf{5 . 6 1} \\
\mathbf{5 . 4 1} \\
\mathbf{5 . 6 7}\end{array}$ & $\begin{array}{c}\{1.6\} \\
\{2.6\} \\
\{2.3\} \\
2.2\end{array}$ & $\begin{array}{r}1 \\
4 \\
10 \\
5\end{array}$ & $\begin{array}{l}6.9 \\
6.9 \\
7.9 \\
7.2\end{array}$ \\
\hline $\begin{array}{l}\text { UT PC-6-1.......... } \\
\text { UT PC-6-2........... } \\
\text { UT PC-6-3.......... } \\
\text { AVG PC-6.......... }\end{array}$ & $\begin{array}{l}36 \\
37 \\
36 \\
36\end{array}$ & $\begin{array}{l}- \\
-\end{array}$ & $\begin{array}{l}32 \\
\frac{30}{31}\end{array}$ & $\begin{array}{l}33 \\
34 \\
37 \\
35\end{array}$ & $\begin{array}{l}28 \\
32 \\
28 \\
29\end{array}$ & $\begin{array}{l}34 \\
31 \\
41 \\
36\end{array}$ & $\bar{z}$ & $\begin{array}{l}3.41 \\
3.27 \\
3.24 \\
3.31\end{array}$ & $\begin{array}{l}2.3 \\
2.8 \\
2.3 \\
2.5\end{array}$ & $\begin{array}{c}- \\
-\end{array}$ & $\begin{array}{r}9 \\
9 \\
11 \\
10\end{array}$ & $\begin{array}{l}3.0 \\
2.9 \\
2.9 \\
2.9\end{array}$ \\
\hline $\begin{array}{l}\text { WV PC- } 7-1 \\
\text { WV PC-7-2 } \ldots \ldots \ldots . . . . \\
\text { WV PC-7-3 ......... } \\
\text { AVG PC-7 .......... }\end{array}$ & $\begin{array}{l}166 \\
116 \\
116 \\
133\end{array}$ & $\begin{array}{l}110 \\
112 \\
107 \\
110\end{array}$ & $\begin{array}{l}120 \\
120 \\
130 \\
120\end{array}$ & $\begin{array}{l}110 \\
140 \\
120 \\
120\end{array}$ & $\begin{array}{l}230 \\
202 \\
200 \\
210\end{array}$ & $\begin{array}{l}130 \\
140 \\
120 \\
130\end{array}$ & $\bar{z}$ & $\begin{array}{l}21.7 \\
21.6 \\
21.3 \\
21.5\end{array}$ & $\begin{array}{l}17 \\
18 \\
17 \\
17\end{array}$ & $\begin{array}{l}15 \\
18 \\
19 \\
17\end{array}$ & $\begin{array}{l}15 \\
18 \\
14 \\
16\end{array}$ & $\begin{array}{l}14 \\
14 \\
12 \\
14\end{array}$ \\
\hline $\begin{array}{l}\text { ND PC-8-1 } \ldots \ldots \ldots . . \\
\text { ND PC-8-2 .......... } \\
\text { ND PC-8-3 .......... } \\
\text { AVG PC-8 .......... }\end{array}$ & $\begin{array}{l}699 \\
660 \\
671 \\
680\end{array}$ & $\begin{array}{l}480 \\
470 \\
450 \\
460\end{array}$ & $\begin{array}{l}430 \\
390 \\
450 \\
420\end{array}$ & $\begin{array}{l}\mathbf{5 2 0} \\
\mathbf{5 3 0} \\
\mathbf{5 3 0} \\
\mathbf{5 3 0}\end{array}$ & $\begin{array}{l}1,000 \\
1,040 \\
1,060 \\
1,030\end{array}$ & $\begin{array}{l}500 \\
700 \\
540 \\
580\end{array}$ & $\bar{z}$ & $\begin{array}{l}2.79 \\
2.84 \\
2.84 \\
2.82\end{array}$ & $\begin{array}{l}1.9 \\
1.9 \\
1.9 \\
1.9\end{array}$ & $\begin{array}{l}- \\
-\end{array}$ & $\begin{array}{r}8 \\
6 \\
10 \\
8\end{array}$ & $\begin{array}{l}3.5 \\
3.8 \\
3.7 \\
3.7\end{array}$ \\
\hline
\end{tabular}


Appendix 1. Comparison of the concentrations of 51 elements determined by multiple analytical techniques in 8 Argonne Premium Coal samples-Continued.

[Analyses of splits for each sample are followed by an average. - , no data. See definitions on $p$. 77]

\begin{tabular}{|c|c|c|c|c|c|c|c|c|c|c|c|c|c|}
\hline \multirow[b]{2}{*}{$\begin{array}{l}\text { Technique................. } \\
\text { Mat. analyzed .......... } \\
\text { Location .................... }\end{array}$} & \multicolumn{5}{|c|}{$\mathrm{Ce}(\mathrm{ppm})$} & \multicolumn{2}{|c|}{$\operatorname{Pr}(\mathrm{ppm})$} & \multicolumn{3}{|c|}{$\mathrm{Nd}(\mathrm{ppm})$} & \multicolumn{3}{|c|}{ Sm (ppm) } \\
\hline & $\begin{array}{c}\text { INAA } \\
\text { WC } \\
\mathbf{R}\end{array}$ & $\begin{array}{c}\text { ICAP-MS } \\
\text { Ash } \\
\text { D }\end{array}$ & $\begin{array}{c}\text { EDXRF } \\
\text { Ash } \\
\text { R }\end{array}$ & $\begin{array}{c}\text { EDXRF } \\
\text { WC } \\
\text { R }\end{array}$ & $\begin{array}{c}\text { DCAES } \\
\text { Ash } \\
\text { R }\end{array}$ & $\begin{array}{c}\text { ICAP-MS } \\
\text { Ash } \\
\text { D }\end{array}$ & $\begin{array}{c}\text { DCAES } \\
\text { Ash } \\
\text { R }\end{array}$ & $\begin{array}{c}\text { INAA } \\
\text { WC } \\
\mathbf{R}\end{array}$ & $\begin{array}{c}\text { ICAP-MS } \\
\text { Ash } \\
\text { D }\end{array}$ & $\begin{array}{c}\text { DCAES } \\
\text { Ash } \\
\mathbf{R}\end{array}$ & $\begin{array}{c}\text { INAA } \\
\text { WC } \\
\mathbf{R}\end{array}$ & $\begin{array}{c}\text { ICAP-MS } \\
\text { Ash } \\
\text { D }\end{array}$ & $\begin{array}{l}\text { DCAES } \\
\text { Ash } \\
\mathbf{R}\end{array}$ \\
\hline $\begin{array}{l}\text { UF PC- } 1-1 \ldots \ldots \ldots \\
\text { UF PC- } 1-2 \ldots \ldots \ldots \ldots \\
\text { UF PC- } 1-3 \ldots \ldots \ldots \ldots \\
\text { AVG PC }-1 \ldots \ldots \ldots \ldots\end{array}$ & $\begin{array}{l}18.1 \\
18.2 \\
18.7 \\
18.3\end{array}$ & $\begin{array}{l}15.0 \\
17.3 \\
18.4 \\
17.6\end{array}$ & $\begin{array}{l}15.1 \\
18.4 \\
17.5 \\
17.0\end{array}$ & $\begin{array}{l}27 \\
46 \\
48 \\
40\end{array}$ & $\begin{array}{l}<9 \\
10 \\
<9 \\
(10)\end{array}$ & $\begin{array}{l}1.82 \\
1.96 \\
2.01 \\
1.93\end{array}$ & $\begin{array}{l}<14 \\
<14 \\
<14 \\
\end{array}$ & $\begin{array}{c}<20 \\
<18 \\
\mathbf{8 . 0} \\
(\mathbf{8 . 0})\end{array}$ & $\begin{array}{l}7.2 \\
7.4 \\
7.8 \\
7.5\end{array}$ & $\begin{array}{l}10 \\
<4 \\
5.0 \\
8\end{array}$ & $\begin{array}{l}1.98 \\
1.94 \\
2.00 \\
1.97\end{array}$ & $\begin{array}{l}1.47 \\
1.51 \\
1.65 \\
1.55\end{array}$ & $\begin{array}{c}<1.4 \\
<1.4 \\
<1.4 \\
-\end{array}$ \\
\hline $\begin{array}{l}\text { WY PC- } 2-1 \ldots \ldots \ldots \\
\text { WY PC- } 2-2 \ldots \ldots \ldots \\
\text { WY PC- } 2-3 \ldots \ldots \ldots \ldots \\
\text { AVG PC-2 } \ldots \ldots \ldots \ldots . .\end{array}$ & $\begin{array}{l}9.07 \\
9.5 \\
9.6 \\
9.4\end{array}$ & $\begin{array}{l}8.0 \\
7.6 \\
8.5 \\
8.0\end{array}$ & $\begin{array}{c}6.1 \\
4.2 \\
<3 \\
5.2\end{array}$ & $\begin{array}{l}18 \\
21 \\
35 \\
25\end{array}$ & $\begin{array}{c}6.3 \\
10 \\
9.3 \\
9\end{array}$ & $\begin{array}{l}.918 \\
.867 \\
.994 \\
.926\end{array}$ & $\begin{array}{l}<9 \\
<9 \\
<9 \\
-\end{array}$ & $\begin{array}{l}<13 \\
<11 \\
<9 \\
-\end{array}$ & $\begin{array}{c}3.7 \\
3.4 \\
3.7 \\
3.6\end{array}$ & $\begin{array}{l}<6 \\
<6 \\
<6 \\
-\end{array}$ & $\begin{array}{l}.968 \\
.988 \\
.977 \\
.978\end{array}$ & $\begin{array}{l}.71 \\
.65 \\
.76 \\
.71\end{array}$ & $\begin{array}{l}<.8 \\
<.8 \\
<.8 \\
-\end{array}$ \\
\hline $\begin{array}{l}\text { IL PC-3-1 } \\
\text { IL PC-3-2 } \\
\text { IL PC-3 } 3 \ldots \ldots \ldots \ldots \\
\text { AVG PC-3 } 3 \ldots \ldots \ldots \ldots \ldots\end{array}$ & $\begin{array}{l}12.5 \\
12.5 \\
12.8 \\
12.6\end{array}$ & $\begin{array}{l}13 \\
13 \\
11 \\
12\end{array}$ & $\begin{array}{l}6.8 \\
8.4 \\
6.5 \\
7.2\end{array}$ & $\begin{array}{l}23 \\
39 \\
64 \\
40\end{array}$ & $\begin{array}{c}<32 \\
<32 \\
28 \\
(28)\end{array}$ & $\begin{array}{l}1.4 \\
1.5 \\
1.2 \\
1.3\end{array}$ & $\begin{array}{l}<17 \\
<17 \\
<17 \\
-\end{array}$ & $\begin{array}{r}<10 \\
<8 \\
<11 \\
-\end{array}$ & $\begin{array}{l}5.5 \\
5.7 \\
4.5 \\
5.2\end{array}$ & $\begin{array}{c}<11 \\
<11 \\
6.5 \\
(6.5)\end{array}$ & $\begin{array}{l}1.19 \\
1.18 \\
1.22 \\
1.20\end{array}$ & $\begin{array}{c}1.1 \\
1.1 \\
.86 \\
1.0\end{array}$ & $\begin{array}{c}<1.6 \\
<1.6 \\
<1.6 \\
-\end{array}$ \\
\hline $\begin{array}{l}\text { PITT PC-4-1....... } \\
\text { PITT PC- } 42 \ldots \ldots \ldots \\
\text { PITT PC-4-3....... } \\
\text { AVG PC-4........... }\end{array}$ & $\begin{array}{l}11.5 \\
11.5 \\
11.1 \\
11.3\end{array}$ & $\begin{array}{l}10.7 \\
10.3 \\
9.75 \\
10.3\end{array}$ & $\begin{array}{l}7.4 \\
9.94 \\
9.57 \\
9.0\end{array}$ & $\begin{array}{r}19 \\
25 \\
6 \\
17\end{array}$ & $\begin{array}{l}<18 \\
<18 \\
<18 \\
-\end{array}$ & $\begin{array}{l}1.18 \\
1.11 \\
1.07 \\
1.12\end{array}$ & $\begin{array}{l}<10 \\
<10 \\
<10 \\
-\end{array}$ & $\begin{array}{l}<12 \\
<8 \\
<10 \\
-\end{array}$ & $\begin{array}{l}4.7 \\
4.3 \\
4.0 \\
4.3\end{array}$ & $\begin{array}{l}4.3 \\
4.2 \\
3.2 \\
3.9\end{array}$ & $\begin{array}{l}1.10 \\
1.09 \\
1.09 \\
1.10\end{array}$ & $\begin{array}{l}.91 \\
.75 \\
.81 \\
.83\end{array}$ & $\begin{array}{l}<.9 \\
<.9 \\
<.9 \\
-\end{array}$ \\
\hline $\begin{array}{l}\text { POC PC-5-1 } \\
\text { POC PC-5...... } \\
\text { POC PC-5-3 .......... } \\
\text { AVG PC-5............ }\end{array}$ & $\begin{array}{l}11.6 \\
11.8 \\
11.5 \\
11.6\end{array}$ & $\begin{array}{l}12.0 \\
11.2 \\
10.9 \\
11.3\end{array}$ & $\begin{array}{l}\{5.30\} \\
8.59 \\
8.90 \\
7.6\end{array}$ & $\begin{array}{r}4 \\
19 \\
8 \\
10\end{array}$ & $\begin{array}{l}12 \\
10 \\
14 \\
12\end{array}$ & $\begin{array}{l}1.38 \\
1.29 \\
1.20 \\
1.29\end{array}$ & $\begin{array}{l}<6 \\
<6 \\
<6 \\
-\end{array}$ & $\begin{array}{l}<18 \\
<16 \\
<14 \\
\end{array}$ & $\begin{array}{l}5.51 \\
4.9 \\
4.7 \\
5.1\end{array}$ & $\begin{array}{l}5.3 \\
6.9 \\
5.8 \\
6.0\end{array}$ & $\begin{array}{l}1.23 \\
1.21 \\
1.21 \\
1.22\end{array}$ & $\begin{array}{l}1.05 \\
.965 \\
.965 \\
.995\end{array}$ & $\begin{array}{l}.74 \\
.69 \\
.85 \\
.76\end{array}$ \\
\hline 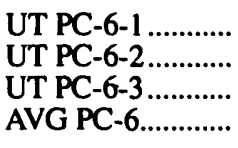 & $\begin{array}{l}4.88 \\
4.67 \\
4.84 \\
4.81\end{array}$ & $\begin{array}{l}4.5 \\
4.83 \\
4.69 \\
4.7\end{array}$ & $\begin{array}{l}- \\
- \\
-\end{array}$ & $\begin{array}{l}20 \\
13 \\
12 \\
15\end{array}$ & $\begin{array}{l}7.4 \\
7.4 \\
6.0 \\
6.9\end{array}$ & $\begin{array}{l}. \mathbf{5 2 4} \\
. \mathbf{5 5 7} \\
\mathbf{. 5 5 7} \\
.546\end{array}$ & $\begin{array}{l}.44 \\
.42 \\
.39 \\
.42\end{array}$ & $\begin{array}{l}<3 \\
2.5 \\
1.6 \\
2.0\end{array}$ & $\begin{array}{l}2.1 \\
2.1 \\
2.1 \\
2.1\end{array}$ & $\begin{array}{l}2.9 \\
<7 \\
<7 \\
(2.9)\end{array}$ & $\begin{array}{l}. \mathbf{5 1 7} \\
. \mathbf{5 0 0} \\
. \mathbf{5 0 7} \\
. \mathbf{5 0 8}\end{array}$ & $\begin{array}{l}.36 \\
.37 \\
.39 \\
.37\end{array}$ & $\begin{array}{l}.37 \\
.38 \\
.36 \\
.37\end{array}$ \\
\hline 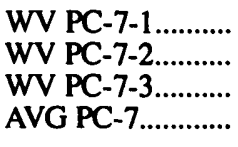 & $\begin{array}{l}36.0 \\
35.2 \\
36.1 \\
35.8\end{array}$ & $\begin{array}{l}35.7 \\
38.4 \\
37.1 \\
37.1\end{array}$ & $\begin{array}{l}28.2 \\
31.7 \\
29.9 \\
29.9\end{array}$ & $\begin{array}{l}64 \\
54 \\
48 \\
55\end{array}$ & $\begin{array}{l}25 \\
27 \\
25 \\
26\end{array}$ & $\begin{array}{l}3.86 \\
4.28 \\
4.04 \\
4.06\end{array}$ & $\begin{array}{l}1.94 \\
1.79 \\
<2 \\
1.87\end{array}$ & $\begin{array}{l}12.4 \\
11.0 \\
12.4 \\
11.9\end{array}$ & $\begin{array}{l}15 \\
16 \\
14 \\
15\end{array}$ & $\begin{array}{l}19 \\
19 \\
18 \\
19\end{array}$ & $\begin{array}{l}3.56 \\
3.50 \\
3.51 \\
3.52\end{array}$ & $\begin{array}{l}2.72 \\
2.95 \\
2.74 \\
2.80\end{array}$ & $\begin{array}{l}1.7 \\
1.7 \\
<.6 \\
1.7\end{array}$ \\
\hline 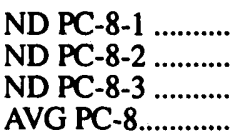 & $\begin{array}{l}4.34 \\
4.33 \\
4.68 \\
4.45\end{array}$ & $\begin{array}{l}4.2 \\
4.1 \\
4.0 \\
4.1\end{array}$ & $\begin{array}{l}- \\
-\end{array}$ & $\begin{array}{l}21 \\
19 \\
17 \\
19\end{array}$ & $\begin{array}{l}<6 \\
<6 \\
<6 \\
\end{array}$ & $\begin{array}{l}.41 \\
.47 \\
.42 \\
.43\end{array}$ & $\begin{array}{l}<.7 \\
<.7 \\
<.7 \\
-\end{array}$ & $\begin{array}{l}<3 \\
2.1 \\
2.5 \\
2.3\end{array}$ & $\begin{array}{l}1.5 \\
1.6 \\
1.4 \\
1.5\end{array}$ & $\begin{array}{r}<3 \\
<3 \\
<14 \\
\end{array}$ & $\begin{array}{l}.420 \\
.419 \\
.388 \\
.409\end{array}$ & $\begin{array}{l}.27 \\
.26 \\
.24 \\
.26\end{array}$ & $\begin{array}{l}<.3 \\
<.3 \\
.47 \\
(.47)\end{array}$ \\
\hline
\end{tabular}


Appendix 1. Comparison of the concentrations of 51 elements determined by multiple analytical techniques in 8 Argonne Premium Coal samples-Continued.

[Analyses of splits for each sample are followed by an average. - , no data. See definitions on p. 77]

\begin{tabular}{|c|c|c|c|c|c|c|c|c|c|c|c|c|c|c|}
\hline \multirow[b]{2}{*}{$\begin{array}{l}\text { Technique ........... } \\
\text { Mat. analyzed .... } \\
\text { Location.............. }\end{array}$} & \multicolumn{3}{|c|}{ Eu (ppm) } & \multicolumn{2}{|c|}{$\mathrm{Tb}(\mathrm{ppm})$} & \multicolumn{3}{|c|}{$\mathrm{Yb}(\mathrm{ppm})$} & \multicolumn{2}{|c|}{ Hf (ppm) } & \multicolumn{2}{|c|}{$\mathrm{Ta}(\mathrm{ppm})$} & \multicolumn{2}{|c|}{ W (ppm) } \\
\hline & $\begin{array}{c}\text { INAA } \\
\mathbf{W C} \\
\mathbf{R}\end{array}$ & $\begin{array}{c}\text { ICAP-MS } \\
\text { Ash } \\
\text { D }\end{array}$ & $\begin{array}{c}\text { DCAES } \\
\text { Ash } \\
\text { R }\end{array}$ & $\begin{array}{c}\text { INAA } \\
\text { WC } \\
\mathbf{R}\end{array}$ & $\begin{array}{c}\text { ICAP-MS } \\
\text { Ash } \\
\text { D }\end{array}$ & $\begin{array}{c}\text { INAA } \\
\text { WC } \\
\mathbf{R}\end{array}$ & $\begin{array}{c}\text { ICAP-MS } \\
\text { Ash } \\
\text { D }\end{array}$ & $\begin{array}{c}\text { DCAES } \\
\text { Ash } \\
\text { R }\end{array}$ & $\begin{array}{c}\text { INAA } \\
\text { WC } \\
\mathbf{R}\end{array}$ & $\begin{array}{c}\text { ICAP-MS } \\
\text { Ash } \\
\text { D }\end{array}$ & $\begin{array}{c}\text { INAA } \\
\text { WC } \\
\mathbf{R}\end{array}$ & $\begin{array}{c}\text { ICAP-MS } \\
\text { Ash } \\
\text { D }\end{array}$ & $\begin{array}{c}\text { INAA } \\
\text { WC } \\
\mathbf{R}\end{array}$ & $\begin{array}{c}\text { ICAP-MS } \\
\text { Ash } \\
\text { D }\end{array}$ \\
\hline 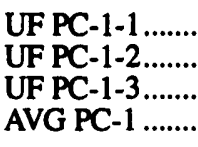 & $\begin{array}{r}0.389 \\
.399 \\
.406 \\
.398\end{array}$ & $\begin{array}{r}\mathbf{0 . 3 2} \\
.35 \\
.34 \\
.34\end{array}$ & $\begin{array}{l}<0.3 \\
<.3 \\
<.3 \\
-\end{array}$ & $\begin{array}{r}0.275 \\
.252 \\
.260 \\
.262\end{array}$ & $\begin{array}{r}0.22 \\
.24 \\
.24 \\
.23\end{array}$ & $\begin{array}{r}0.91 \\
.84 \\
.90 \\
.88\end{array}$ & $\begin{array}{r}0.74 \\
.78 \\
.92 \\
.81\end{array}$ & $\begin{array}{r}0.84 \\
.82 \\
.86 \\
.84\end{array}$ & $\begin{array}{l}0.647 \\
.660 \\
.67 \\
.66\end{array}$ & $\begin{array}{r}0.81 \\
.80 \\
.92 \\
.85\end{array}$ & $\begin{array}{r}0.207 \\
.224 \\
.227 \\
.219\end{array}$ & $\begin{array}{r}0.22 \\
.19 \\
.18 \\
.20\end{array}$ & $\begin{array}{l}1.00 \\
1.09 \\
1.09 \\
1.06\end{array}$ & $\begin{array}{l}1.1 \\
1.3 \\
1.3 \\
1.2\end{array}$ \\
\hline $\begin{array}{l}\text { WY PC-2-1 ..... } \\
\text { WY PC-2-2 .... } \\
\text { WY PC-2-3 .... } \\
\text { AVG PC-2 ...... }\end{array}$ & $\begin{array}{l}.201 \\
.199 \\
.195 \\
.198\end{array}$ & $\begin{array}{l}.15 \\
.16 \\
.19 \\
.17\end{array}$ & $\begin{array}{l}<.2 \\
<.2 \\
<.2 \\
-\end{array}$ & $\begin{array}{l}.122 \\
.122 \\
.115 \\
.120\end{array}$ & $\begin{array}{l}.10 \\
.10 \\
.11 \\
.10\end{array}$ & $\begin{array}{l}.42 \\
.443 \\
.40 \\
.42\end{array}$ & $\begin{array}{l}.32 \\
.36 \\
.44 \\
.37\end{array}$ & $\begin{array}{l}.23 \\
.30 \\
.35 \\
.29\end{array}$ & $\begin{array}{l}.621 \\
.622 \\
.560 \\
.601\end{array}$ & $\begin{array}{l}.65 \\
.68 \\
.71 \\
.68\end{array}$ & $\begin{array}{l}.141 \\
.155 \\
.142 \\
.146\end{array}$ & $\begin{array}{l}.13 \\
.12 \\
.10 \\
.12\end{array}$ & $\begin{array}{l}.38 \\
.36 \\
.40 \\
.38\end{array}$ & $\begin{array}{l}.48 \\
.41 \\
.49 \\
.46\end{array}$ \\
\hline 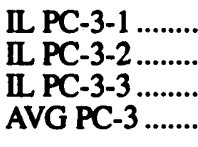 & $\begin{array}{l}.229 \\
.222 \\
.227 \\
.226\end{array}$ & $\begin{array}{l}.23 \\
.19 \\
.18 \\
.20\end{array}$ & $\begin{array}{l}<.4 \\
<.4 \\
<.4 \\
-\end{array}$ & $\begin{array}{l}.147 \\
.131 \\
.136 \\
.138\end{array}$ & $\begin{array}{l}.14 \\
.15 \\
.12 \\
.14\end{array}$ & $\begin{array}{l}. \mathbf{5 1} \\
. \mathbf{5 1 1} \\
.551 \\
.52\end{array}$ & $\begin{array}{l}.52 \\
\mathbf{5 2} \\
\mathbf{5 2} \\
\mathbf{5 2}\end{array}$ & $\begin{array}{l}.63 \\
.58 \\
.68 \\
.61\end{array}$ & $\begin{array}{l}.54 \\
.532 \\
.578 \\
.55\end{array}$ & $\begin{array}{l}.92 \\
.71 \\
.68 \\
.76\end{array}$ & $\begin{array}{l}.188 \\
.197 \\
.189 \\
.191\end{array}$ & $\begin{array}{l}.19 \\
.18 \\
.16 \\
.18\end{array}$ & $\begin{array}{l}1.53 \\
1.52 \\
1.50 \\
1.52\end{array}$ & $\begin{array}{l}1.9 \\
2.1 \\
1.7 \\
1.62\end{array}$ \\
\hline $\begin{array}{l}\text { PITT PC-4-1 ... } \\
\text { PITT PC-4-2 ... } \\
\text { PITT PC-4-3 ... } \\
\text { AVG PC-4 ...... }\end{array}$ & $\begin{array}{l}.221 \\
.214 \\
.208 \\
.214\end{array}$ & $\begin{array}{l}.17 \\
.18 \\
.17 \\
.17\end{array}$ & $\begin{array}{l}<.3 \\
<.3 \\
<.3 \\
-\end{array}$ & $\begin{array}{l}.133 \\
.131 \\
.132 \\
.132\end{array}$ & $\begin{array}{l}.11 \\
.12 \\
.11 \\
.11\end{array}$ & $\begin{array}{l}.478 \\
.463 \\
.468 \\
.470\end{array}$ & $\begin{array}{l}.44 \\
.42 \\
.43 \\
.43\end{array}$ & $\begin{array}{l}.63 \\
.51 \\
.48 \\
.54\end{array}$ & $\begin{array}{l}.518 \\
.49 \\
.500 \\
.50\end{array}$ & $\begin{array}{l}.63 \\
.61 \\
.60 \\
.61\end{array}$ & $\begin{array}{l}.168 \\
.163 \\
.168 \\
.166\end{array}$ & $\begin{array}{l}.13 \\
.14 \\
.13 \\
.13\end{array}$ & $\begin{array}{l}.79 \\
.80 \\
.76 \\
.78\end{array}$ & $\begin{array}{l}.89 \\
.86 \\
.82 \\
.86\end{array}$ \\
\hline $\begin{array}{l}\text { POC PC-5-1 .... } \\
\text { POC PC }-5-2 \ldots \\
\text { POC PC-5-3 .... } \\
\text { AVG PC-5 ...... }\end{array}$ & $\begin{array}{l}.243 \\
.241 \\
.218 \\
.234\end{array}$ & $\begin{array}{l}.22 \\
.21 \\
.21 \\
.21\end{array}$ & $\begin{array}{l}<.3 \\
<.2 \\
<.2 \\
-\end{array}$ & $\begin{array}{l}.158 \\
.173 \\
.169 \\
.167\end{array}$ & $\begin{array}{l}.17 \\
.16 \\
.15 \\
.16\end{array}$ & $\begin{array}{l}.555 \\
.56 \\
.545 \\
.555\end{array}$ & $\begin{array}{l}\mathbf{5 7 8} \\
\mathbf{. 5 7 2} \\
\mathbf{. 5 6 7} \\
\mathbf{. 5 7 2}\end{array}$ & $\begin{array}{l}.46 \\
.47 \\
.42 \\
.45\end{array}$ & $\begin{array}{l}.441 \\
.429 \\
.444 \\
.438\end{array}$ & $\begin{array}{l}.58 \\
.58 \\
.53 \\
.56\end{array}$ & $\begin{array}{l}.117 \\
.108 \\
.123 \\
.116\end{array}$ & $\begin{array}{l}.13 \\
.11 \\
.10 \\
.11\end{array}$ & $\begin{array}{l}.84 \\
.91 \\
.77 \\
.84\end{array}$ & $\begin{array}{l}1.2 \\
1.1 \\
1.0 \\
1.1\end{array}$ \\
\hline $\begin{array}{l}\text { UT PC-6-1....... } \\
\text { UT PC-6-2...... } \\
\text { UT PC-6-3...... } \\
\text { AVG PC-6...... }\end{array}$ & $\begin{array}{l}.100 \\
.098 \\
.098 \\
.099\end{array}$ & $\begin{array}{l}.078 \\
.087 \\
.087 \\
.084\end{array}$ & $\begin{array}{l}<.2 \\
<.1 \\
.11 \\
(.11)\end{array}$ & $\begin{array}{l}.065 \\
.054 \\
.054 \\
.058\end{array}$ & $\begin{array}{l}.051 \\
.060 \\
.055 \\
.055\end{array}$ & $\begin{array}{l}.204 \\
.198 \\
.211 \\
.204\end{array}$ & $\begin{array}{l}.19 \\
.20 \\
.21 \\
.20\end{array}$ & $\begin{array}{l}.22 \\
.20 \\
.21 \\
.21\end{array}$ & $\begin{array}{l}.478 \\
.499 \\
.458 \\
.478\end{array}$ & $\begin{array}{l}.51 \\
.60 \\
.56 \\
.56\end{array}$ & $\begin{array}{l}.060 \\
.046 \\
.038 \\
.048\end{array}$ & $\begin{array}{l}.055 \\
.060 \\
.056 \\
.046\end{array}$ & $\begin{array}{l}.42 \\
.40 \\
.38 \\
.42\end{array}$ & $\begin{array}{l}.51 \\
.51 \\
.51 \\
.51\end{array}$ \\
\hline $\begin{array}{l}\text { WV PC-7-1 } \ldots . . \\
\text { WV PC-7-2 .... } \\
\text { WV PC-7-3 .... } \\
\text { AVG PC-7 ...... }\end{array}$ & $\begin{array}{l}.674 \\
.651 \\
.697 \\
.674\end{array}$ & $\begin{array}{l}.60 \\
.62 \\
.62 \\
.61\end{array}$ & $\begin{array}{l}.47 \\
.48 \\
.89 \\
.61\end{array}$ & $\begin{array}{l}.408 \\
.390 \\
.402 \\
.400\end{array}$ & $\begin{array}{l}.37 \\
.43 \\
.39 \\
.40\end{array}$ & $\begin{array}{l}1.69 \\
1.61 \\
1.52 \\
1.61\end{array}$ & $\begin{array}{l}1.4 \\
1.7 \\
1.5 \\
1.5\end{array}$ & $\begin{array}{l}1.8 \\
1.4 \\
1.4 \\
1.5\end{array}$ & $\begin{array}{l}1.88 \\
1.80 \\
1.80 \\
1.83\end{array}$ & $\begin{array}{l}2.3 \\
2.3 \\
2.3 \\
2.3\end{array}$ & $\begin{array}{l}.675 \\
.617 \\
.630 \\
.641\end{array}$ & $\begin{array}{l}.62 \\
.68 \\
.56 \\
.583\end{array}$ & $\begin{array}{l}1.33 \\
1.19 \\
2.53 \\
1.68\end{array}$ & $\begin{array}{r}1.6 \\
\{18\} \\
1.7 \\
1.6\end{array}$ \\
\hline $\begin{array}{l}\text { ND PC-8-1 } \ldots \ldots . \\
\text { ND PC-8 } 2 \ldots . . \\
\text { ND PC-8 } 3 \ldots \ldots \\
\text { AVG PC-8 } \ldots \ldots .\end{array}$ & $\begin{array}{l}.079 \\
.077 \\
.087 \\
.081\end{array}$ & $\begin{array}{l}.053 \\
.052 \\
.058 \\
.054\end{array}$ & $\begin{array}{l}<.2 \\
<.2 \\
<.2 \\
-\end{array}$ & $\begin{array}{l}.052 \\
.052 \\
.063 \\
.056\end{array}$ & $\begin{array}{l}.053 \\
.053 \\
.058 \\
.055\end{array}$ & $\begin{array}{l}.317 \\
.298 \\
.245 \\
.287\end{array}$ & $\begin{array}{l}.21 \\
.25 \\
.23 \\
.23\end{array}$ & $\begin{array}{l}.22 \\
.19 \\
.20 \\
.20\end{array}$ & $\begin{array}{l}.342 \\
.341 \\
.340 \\
.341\end{array}$ & $\begin{array}{l}.41 \\
.45 \\
.41 \\
.42\end{array}$ & $\begin{array}{l}.095 \\
.088 \\
.095 \\
.092\end{array}$ & $\begin{array}{r}<0.1 \\
<0.1 \\
<0.1 \\
-\end{array}$ & $\begin{array}{l}.38 \\
.25 \\
.43 \\
.35\end{array}$ & $\begin{array}{l}.34 \\
.38 \\
.36 \\
.36\end{array}$ \\
\hline
\end{tabular}


Appendix 1. Comparison of the concentrations of 51 elements determined by multiple analytical techniques in 8 Argonne Premium Coal samples-Continued.

[Analyses of splits for each sample are followed by an average. —, no data. See definitions on p. 77]

\begin{tabular}{|c|c|c|c|c|c|c|c|c|c|c|}
\hline \multirow[b]{2}{*}{$\begin{array}{l}\text { Technique .................... } \\
\text { Material analyzed ......... } \\
\text { Location ......................... }\end{array}$} & \multicolumn{4}{|c|}{$\mathrm{Pb}(\mathrm{ppm})$} & \multicolumn{2}{|c|}{$\mathrm{Bi}$ (ppm) } & \multicolumn{2}{|c|}{ Th (ppm) } & \multicolumn{2}{|c|}{$\mathrm{U}(\mathrm{ppm})$} \\
\hline & $\begin{array}{c}\text { GFAAS } \\
\text { Ash } \\
\text { R }\end{array}$ & $\begin{array}{c}\text { ICAP-MS } \\
\text { Ash } \\
\text { D }\end{array}$ & $\begin{array}{c}\text { DCAES } \\
\text { Ash } \\
\mathbf{R}\end{array}$ & $\begin{array}{c}\text { DCAES } \\
\text { WC } \\
\text { R }\end{array}$ & $\begin{array}{c}\text { ICAP-MS } \\
\text { Ash } \\
\text { D }\end{array}$ & $\begin{array}{c}\text { DCAES } \\
\text { Ash } \\
\text { R }\end{array}$ & $\begin{array}{c}\text { INAA } \\
\mathbf{W C} \\
\mathbf{R}\end{array}$ & $\begin{array}{c}\text { ICAP-AES } \\
\text { Ash } \\
\text { D }\end{array}$ & $\begin{array}{c}\text { INAA } \\
\text { WC } \\
\mathbf{R}\end{array}$ & $\begin{array}{c}\text { ICAP-MS } \\
\text { Ash } \\
\text { D }\end{array}$ \\
\hline 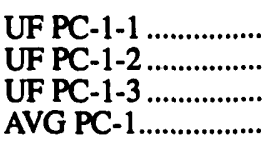 & $\begin{array}{l}7.8 \\
7.4 \\
6.9 \\
7.4\end{array}$ & $\begin{array}{l}7.7 \\
7.7 \\
7.4 \\
7.6\end{array}$ & $\begin{array}{l}10 \\
10 \\
11 \\
10\end{array}$ & $\begin{array}{c}8.0 \\
10 \\
6.0 \\
8\end{array}$ & $\begin{array}{r}0.12 \\
.12 \\
.11 \\
.12\end{array}$ & $\begin{array}{c}<1.4 \\
<1.4 \\
<1.4 \\
-\end{array}$ & $\begin{array}{l}2.59 \\
2.64 \\
1.55 \\
2.26\end{array}$ & $\begin{array}{l}2.8 \\
2.8 \\
2.6 \\
2.7\end{array}$ & $\begin{array}{r}0.81 \\
.81 \\
.86 \\
.83\end{array}$ & $\begin{array}{l}1.2 \\
1.2 \\
1.1 \\
1.2\end{array}$ \\
\hline 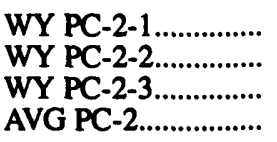 & $\begin{array}{l}3.1 \\
3.0 \\
2.7 \\
2.9\end{array}$ & $\begin{array}{l}1.6 \\
1.6 \\
1.5 \\
1.6\end{array}$ & $\begin{array}{l}2.6 \\
4.1 \\
3.5 \\
3.4\end{array}$ & $\begin{array}{l}<2 \\
<2 \\
<2 \\
-\end{array}$ & $\begin{array}{l}.055 \\
.055 \\
.049 \\
.053\end{array}$ & $\begin{array}{l}<.9 \\
<.9 \\
<.9 \\
-\end{array}$ & $\begin{array}{l}1.56 \\
1.58 \\
2.01 \\
1.71\end{array}$ & $\begin{array}{l}1.4 \\
1.6 \\
1.3 \\
1.4\end{array}$ & $\begin{array}{l}.55 \\
.54 \\
.52 \\
.54\end{array}$ & $\begin{array}{l}.65 \\
.62 \\
.63 \\
.63\end{array}$ \\
\hline 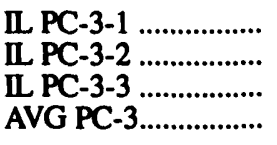 & $\begin{array}{l}6.8 \\
6.3 \\
6.3 \\
6.5\end{array}$ & $\begin{array}{l}8.6 \\
8.7 \\
8.1 \\
8.5\end{array}$ & $\begin{array}{l}14 \\
13 \\
14 \\
14\end{array}$ & $\begin{array}{l}9 \\
8 \\
6 \\
8\end{array}$ & $\begin{array}{c}.089 \\
.087 \\
<.08 \\
.088\end{array}$ & $\begin{array}{l}<1.7 \\
<1.7 \\
<1.7 \\
-\end{array}$ & $\begin{array}{l}1.95 \\
1.95 \\
1.99 \\
1.96\end{array}$ & $\begin{array}{l}2.4 \\
2.1 \\
1.9 \\
2.2\end{array}$ & $\begin{array}{l}4.46 \\
4.06 \\
4.28 \\
4.27\end{array}$ & $\begin{array}{l}6.84 \\
6.58 \\
5.95 \\
6.46\end{array}$ \\
\hline 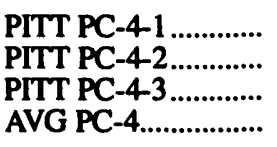 & $\begin{array}{l}2.9 \\
2.9 \\
2.9 \\
2.9\end{array}$ & $\begin{array}{l}3.8 \\
4.0 \\
3.7 \\
3.8\end{array}$ & $\begin{array}{l}7.3 \\
6.9 \\
7.7 \\
7.3\end{array}$ & $\begin{array}{l}4 \\
3 \\
5 \\
4\end{array}$ & $\begin{array}{l}.12 \\
.12 \\
.11 \\
.12\end{array}$ & $\begin{array}{l}2.0 \\
1.5 \\
<.9 \\
1.8\end{array}$ & $\begin{array}{l}1.53 \\
1.46 \\
1.44 \\
1.48\end{array}$ & $\begin{array}{l}1.8 \\
1.4 \\
1.6 \\
1.6\end{array}$ & $\begin{array}{l}.36 \\
.37 \\
.45 \\
.39\end{array}$ & $\begin{array}{l}.60 \\
.56 \\
.55 \\
.57\end{array}$ \\
\hline 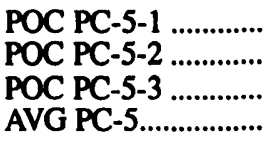 & $\begin{array}{l}2.5 \\
2.4 \\
2.4 \\
2.4\end{array}$ & $\begin{array}{l}1.8 \\
1.7 \\
1.6 \\
1.7\end{array}$ & $\begin{array}{l}12 \\
8.5 \\
12 \\
11\end{array}$ & $\begin{array}{l}5 \\
4 \\
5 \\
5\end{array}$ & $\begin{array}{l}.049 \\
.052 \\
.053 \\
.052\end{array}$ & $\begin{array}{l}<.5 \\
<.5 \\
<.5 \\
-\end{array}$ & $\begin{array}{l}1.19 \\
1.12 \\
1.17 \\
1.16\end{array}$ & $\begin{array}{l}1.2 \\
1.1 \\
1.2 \\
1.2\end{array}$ & $\begin{array}{l}.47 \\
.51 \\
.55 \\
.51\end{array}$ & $\begin{array}{l}.646 \\
.615 \\
.631 \\
.631\end{array}$ \\
\hline 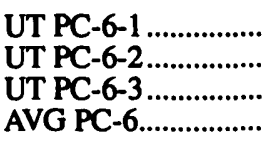 & $\begin{array}{l}1.6 \\
\frac{1.6}{1.6}\end{array}$ & $\begin{array}{l}1.4 \\
1.5 \\
1.5 \\
1.5\end{array}$ & $\begin{array}{l}2.1 \\
1.7 \\
2.0 \\
1.9\end{array}$ & $\frac{-}{E}$ & $\begin{array}{l}.035 \\
.036 \\
.035 \\
.035\end{array}$ & $\begin{array}{l}<1 \\
<1 \\
<1 \\
\end{array}$ & $\begin{array}{l}.609 \\
.614 \\
.622 \\
.615\end{array}$ & $\begin{array}{l}.60 \\
.60 \\
.55 \\
.58\end{array}$ & $\begin{array}{l}.76 \\
.70 \\
.76 \\
.74\end{array}$ & $\begin{array}{l}.851 \\
.823 \\
.819 \\
.852\end{array}$ \\
\hline 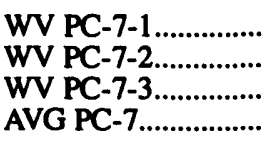 & $\begin{array}{l}12 \\
12 \\
12 \\
12\end{array}$ & $\begin{array}{l}12 \\
12 \\
12 \\
12\end{array}$ & $\begin{array}{l}18 \\
16 \\
13 \\
16\end{array}$ & $\frac{-}{-}$ & $\begin{array}{l}.23 \\
.23 \\
.23 \\
.23\end{array}$ & $\begin{array}{l}<5 \\
<5 \\
<5 \\
-\end{array}$ & $\begin{array}{l}6.49 \\
6.26 \\
6.49 \\
6.41\end{array}$ & $\begin{array}{l}6.2 \\
6.4 \\
6.6 \\
6.4\end{array}$ & $\begin{array}{l}1.67 \\
1.60 \\
1.64 \\
1.64\end{array}$ & $\begin{array}{l}2.17 \\
2.21 \\
2.10 \\
2.16\end{array}$ \\
\hline 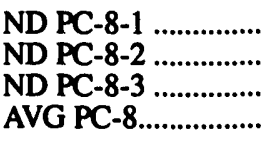 & $\begin{array}{l}1.5 \\
1.5 \\
1.5 \\
1.5\end{array}$ & $\begin{array}{l}1.9 \\
.84 \\
1.5 \\
1.6\end{array}$ & $\begin{array}{l}2.7 \\
2.1 \\
3.0 \\
2.6\end{array}$ & $\frac{-}{E}$ & $\begin{array}{l}<.05 \\
<.05 \\
<.05 \\
-\end{array}$ & $\begin{array}{l}<2 \\
<2 \\
<\end{array}$ & $\begin{array}{l}1.06 \\
1.03 \\
1.11 \\
1.07\end{array}$ & $\begin{array}{l}\{.6\} \\
\{.8\} \\
\{.7\} \\
.7\end{array}$ & $\begin{array}{r}.52 \\
.46 \\
<.2 \\
.49\end{array}$ & $\begin{array}{l}.42 \\
.47 \\
.46 \\
.45\end{array}$ \\
\hline
\end{tabular}




\section{Appendix 2. Statistical parameters for the data in appendix 1.}

Concentrations of 51 elements in 8 Argonne Premium Coals were determined by multiple analytical techniques (appendix 1). Statistical parameters for non-outlier concentrations determined by high-precision (HP) techniques and for concentrations (including outliers) determined by all techniques (HP and less precise techniques) are listed in this appendix in separate columns for each element; only one column is needed for elements for which all values were determined by HP techniques and no concentrations were outliers ( $\mathrm{Li}, \mathrm{Cs}, \mathrm{Tb}, \mathrm{Hf}, \mathrm{Ta}, \mathrm{U}$ ). Concentrations of major elements ( $\mathrm{Si}, \mathrm{Al}, \mathrm{Fe}, \mathrm{Mg}, \mathrm{Ca}, \mathrm{Na}, \mathrm{K}$, $\mathrm{Ti}, \mathrm{P}, \mathrm{Mn}$ ) are in weight percent (wt. \%); concentrations of trace elements are in parts per million (ppm).

The mean values in HP columns are recommended values if there is no box for that sample in that column. They are concentrations determined from the arithmetic mean of the HP values, except values that were excluded in tables 5 and 6 of the paper (this volume) by Palmer and Klizas. The mean concentration is a recommended value if all the following conditions are met:

(1) the number of determinations $(n)$ is greater than 3 ,

(2) the relative standard deviation (Rel Std Dev) is less than 5 percent for major elements present in concentrations greater than 0.1 percent or is less than 10 percent for trace elements or for major elements present in concentrations less than 0.1 percent (see paper by Palmer and Klizas), and

(3) the deviation of the arithmetic mean and the geometric mean (Dev of Means) is less than 1 percent.

If any of these conditions is not met (as indicated by a box around the value), the mean is reported as an average value in tables 5 and 6 of the paper by Palmer and Klizas.

The standard deviation represents the error in the recommended values and was used to determine significant figures. The kurtosis and skewness are also included. ERR indicates that there were insufficient data to calculate the statistical parameter. 
Appendix 2. Statistical parameters for the data in appendix 1-Continued.

\begin{tabular}{|c|c|c|c|c|c|c|c|c|c|c|}
\hline & Si HP & Si All & Al HP & Al All & Fe HP & Fe All & $\mathrm{Mg} \mathrm{HP}$ & Mg All & $\mathrm{Ca} \mathrm{HP}$ & Ca All \\
\hline \multicolumn{11}{|l|}{ UF PC-1 } \\
\hline 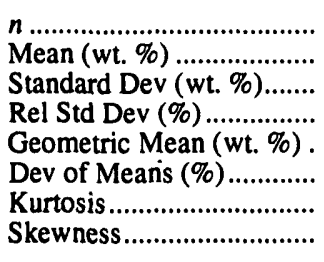 & $\begin{array}{l}5 \\
2.63 \\
.081 \\
3.09 \\
2.62 \\
.04 \\
.641 \\
-1.05\end{array}$ & $\begin{array}{c}11 \\
3.0 \\
.43 \\
14.6 \\
2.9 \\
.89 \\
2.68 \\
1.53\end{array}$ & $\begin{array}{l}8 \\
1.58 \\
.046 \\
2.94 \\
1.57 \\
.04 \\
-.753 \\
-.277\end{array}$ & $\begin{array}{l}14 \\
1.8 \\
.38 \\
20.4 \\
1.8 \\
1.76 \\
.508 \\
1.22\end{array}$ & $\begin{array}{c}11 \\
1.8 \\
.11 \\
5.93 \\
1.8 \\
.16 \\
.0521 \\
-.304\end{array}$ & $\begin{array}{c}17 \\
1.8 \\
.34 \\
18.6 \\
1.8 \\
1.39 \\
8.44 \\
2.32\end{array}$ & $\begin{array}{l}8 \\
.080 \\
.0023 \\
2.93 \\
.079 \\
.04 \\
.900 \\
-.904\end{array}$ & $\begin{array}{l}14 \\
.10 \\
.028 \\
28.8 \\
.09 \\
3.33 \\
.797 \\
1.42\end{array}$ & $\begin{array}{l}8 \\
.42 \\
.023 \\
5.48 \\
.42 \\
.13 \\
-2.17 \\
.590\end{array}$ & $\begin{array}{c}14 \\
.5 \\
.10 \\
21.0 \\
.5 \\
1.98 \\
-1.30 \\
.573\end{array}$ \\
\hline \multicolumn{11}{|c|}{ WY PC-2 } \\
\hline 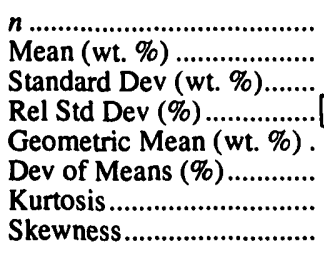 & $\begin{array}{c}5 \\
1.1 \\
.12 \\
11.0 \\
1.1 \\
.49 \\
-2.93 \\
.153\end{array}$ & $\begin{array}{l}11 \\
1.1 \\
.27 \\
24.9 \\
1.0 \\
3.51 \\
.766 \\
-.720\end{array}$ & $\begin{array}{l}8 \\
.68 \\
.034 \\
4.94 \\
.68 \\
.11 \\
-.973 \\
-.567\end{array}$ & $\begin{array}{l}14 \\
.6 \\
.10 \\
17.1 \\
.6 \\
1.50 \\
-.959 \\
-.680\end{array}$ & $\begin{array}{l}11 \\
.35 \\
.025 \\
6.99 \\
.35 \\
.23 \\
-1.00 \\
-.255\end{array}$ & $\begin{array}{c}17 \\
.33 \\
.048 \\
14.8 \\
.32 \\
1.22 \\
1.70 \\
-1.3\end{array}$ & $\begin{array}{c}8 \\
.23 \\
.028 \\
12.3 \\
.23 \\
.67 \\
-1.37 \\
-.033\end{array}$ & $\begin{array}{l}14 \\
.25 \\
.066 \\
26.5 \\
.24 \\
2.91 \\
.321 \\
1.22\end{array}$ & $\begin{array}{l}8 \\
1.12 \\
.087 \\
7.70 \\
1.12 \\
.27 \\
-.124 \\
-.840\end{array}$ & $\begin{array}{c}14 \\
1.1 \\
.13 \\
11.6 \\
1.1 \\
.61 \\
-.147 \\
.735\end{array}$ \\
\hline \multicolumn{11}{|c|}{ IL PC-3 } \\
\hline 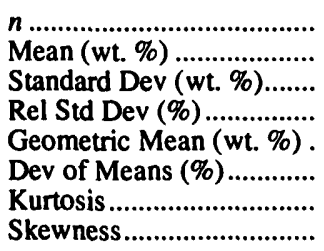 & $\begin{array}{l}4 \\
3.05 \\
.041 \\
1.35 \\
3.04 \\
.01 \\
1.79 \\
.713\end{array}$ & $\begin{array}{l}11 \\
3.2 \\
.43 \\
13.3 \\
3.2 \\
.76 \\
-.0299 \\
1.05\end{array}$ & $\begin{array}{l}7 \\
1.24 \\
.035 \\
2.79 \\
1.24 \\
.03 \\
-1.29 \\
.235\end{array}$ & $\begin{array}{l}14 \\
1.6 \\
.38 \\
24.3 \\
1.5 \\
2.72 \\
-2.08 \\
.337\end{array}$ & $\begin{array}{l}11 \\
2.6 \\
.16 \\
6.16 \\
2.6 \\
.18 \\
.782 \\
-1.32\end{array}$ & $\begin{array}{l}17 \\
2.5 \\
.28 \\
11.0 \\
2.5 \\
.60 \\
-.195 \\
-.588\end{array}$ & $\begin{array}{c}6 \\
.075 \\
.0037 \\
4.94 \\
.075 \\
.11 \\
3.97 \\
-1.89\end{array}$ & $\begin{array}{c}14 \\
.09 \\
.016 \\
17.6 \\
.09 \\
1.43 \\
-.966 \\
.393\end{array}$ & $\begin{array}{c}8 \\
.93 \\
.039 \\
4.16 \\
.93 \\
.08 \\
-1.40 \\
-.532\end{array}$ & $\begin{array}{l}14 \\
1.2 \\
.44 \\
35.4 \\
1.2 \\
5.37 \\
-.951 \\
.920\end{array}$ \\
\hline \multicolumn{11}{|l|}{ PITT PC-4 } \\
\hline 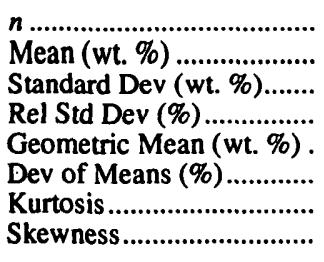 & $\begin{array}{l}5 \\
1.86 \\
.088 \\
4.72 \\
1.86 \\
.09 \\
-3.16 \\
.638\end{array}$ & $\begin{array}{l}11 \\
2.2 \\
.46 \\
20.7 \\
2.2 \\
1.83 \\
-.951 \\
.872\end{array}$ & $\begin{array}{c}7 \\
.99 \\
.011 \\
1.14 \\
.99 \\
.01 \\
-2.26 \\
-.0177\end{array}$ & $\begin{array}{c}14 \\
1.4 \\
.54 \\
39.7 \\
1.3 \\
6.96 \\
-1.61 \\
.732\end{array}$ & $\begin{array}{c}11 \\
1.33 \\
.071 \\
5.33 \\
1.33 \\
.13 \\
.191 \\
-.0179\end{array}$ & $\begin{array}{c}17 \\
1.4 \\
.29 \\
20.7 \\
1.4 \\
1.94 \\
.218 \\
.827\end{array}$ & $\begin{array}{c}6 \\
.036 \\
.0027 \\
7.71 \\
.035 \\
.25 \\
-3.33 \\
-5.7 \times 10-15\end{array}$ & $\begin{array}{c}14 \\
.05 \\
.017 \\
35.9 \\
.04 \\
5.13 \\
2.30 \\
1.55\end{array}$ & $\begin{array}{c}8 \\
.197 \\
.0099 \\
5.02 \\
.197 \\
.11 \\
-1.21 \\
-.313\end{array}$ & $\begin{array}{l}14 \\
.26 \\
.093 \\
35.7 \\
.25 \\
5.23 \\
.330 \\
1.24\end{array}$ \\
\hline \multicolumn{11}{|c|}{ POC PC-5 } \\
\hline 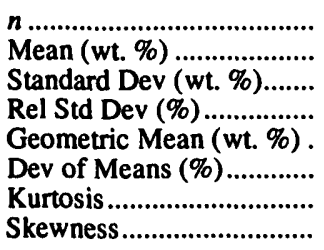 & $\begin{array}{l}4 \\
.76 \\
.038 \\
4.95 \\
.76 \\
.09 \\
.257 \\
.358\end{array}$ & $\begin{array}{c}10 \\
.9 \\
.10 \\
12.1 \\
.8 \\
.65 \\
-1.39 \\
.397\end{array}$ & $\begin{array}{c}7 \\
.552 \\
.0062 \\
1.12 \\
.552 \\
.01 \\
-1.05 \\
.812\end{array}$ & $\begin{array}{l}14 \\
.7 \\
.13 \\
19.9 \\
.6 \\
1.71 \\
-.511 \\
.944\end{array}$ & $\begin{array}{l}11 \\
.51 \\
.015 \\
2.98 \\
.51 \\
.04 \\
-.33 \\
-.892\end{array}$ & $\begin{array}{c}17 \\
.54 \\
.085 \\
15.8 \\
.53 \\
1.01 \\
5.51 \\
2.26\end{array}$ & $\begin{array}{l}8 \\
.058 \\
.0055 \\
9.37 \\
.058 \\
.36 \\
-.225 \\
1.29\end{array}$ & $\begin{array}{c}14 \\
.07 \\
.021 \\
28.2 \\
.07 \\
3.43 \\
-.416 \\
.956\end{array}$ & $\begin{array}{l}8 \\
.452 \\
.0069 \\
1.52 \\
.452 \\
.01 \\
.264 \\
-.0133\end{array}$ & $\begin{array}{c}14 \\
.6 \\
.15 \\
27.7 \\
.5 \\
3.08 \\
1.41 \\
1.47\end{array}$ \\
\hline \multicolumn{11}{|l|}{ UT PC-6 } \\
\hline 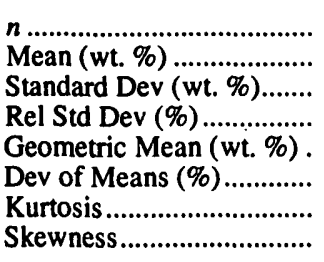 & $\begin{array}{c}4 \\
.91 \\
.027 \\
2.97 \\
.91 \\
.03 \\
-2.57 \\
.257\end{array}$ & $\begin{array}{c}7 \\
.89 \\
.068 \\
7.66 \\
.89 \\
.28 \\
5.17 \\
-2.20\end{array}$ & $\begin{array}{c}6 \\
.37 \\
.020 \\
5.31 \\
.37 \\
.12 \\
-1.89 \\
.045\end{array}$ & $\begin{array}{c}9 \\
.35 \\
.035 \\
10.1 \\
.35 \\
.47 \\
-1.01 \\
-.351\end{array}$ & $\begin{array}{c}9 \\
.30 \\
.016 \\
5.37 \\
.30 \\
.13 \\
-1.19 \\
.509\end{array}$ & $\begin{array}{c}12 \\
.28 \\
.034 \\
12.0 \\
.28 \\
.74 \\
.994 \\
-1.14\end{array}$ & $\begin{array}{l}6 \\
.033 \\
.0074 \\
22.5 \\
.032 \\
1.77 \\
5.57 \\
2.33\end{array}$ & $\begin{array}{c}9 \\
.036 \\
.0071 \\
20.0 \\
.035 \\
1.72 \\
-1.04 \\
-.820\end{array}$ & $\begin{array}{c}5 \\
.41 \\
.013 \\
3.16 \\
.41 \\
.04 \\
-3.07 \\
-.293\end{array}$ & $\begin{array}{c}9 \\
.36 \\
.063 \\
17.3 \\
.36 \\
1.43 \\
-1.98 \\
-.435\end{array}$ \\
\hline \multicolumn{11}{|c|}{ WV PC-7 } \\
\hline 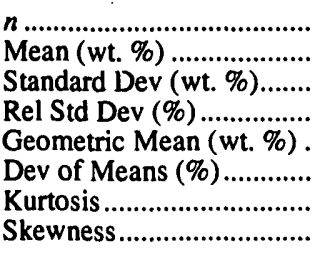 & $\begin{array}{l}4 \\
5.0 \\
.22 \\
4.32 \\
5.0 \\
.07 \\
1.50 \\
1.19\end{array}$ & $\begin{array}{l}7 \\
5.1 \\
.48 \\
9.51 \\
5.1 \\
.39 \\
.274 \\
-.105\end{array}$ & $\begin{array}{l}7 \\
3.16 \\
.024 \\
.75 \\
3.16 \\
0 \\
-.861 \\
-.802\end{array}$ & $\begin{array}{c}10 \\
3.4 \\
.44 \\
12.9 \\
3.4 \\
.68 \\
1.64 \\
1.78\end{array}$ & $\begin{array}{c}10 \\
.39 \\
.014 \\
3.52 \\
.39 \\
.06 \\
-1.30 \\
.242\end{array}$ & $\begin{array}{l}13 \\
.39 \\
.024 \\
6.21 \\
.39 \\
.18 \\
1.69 \\
.647\end{array}$ & $\begin{array}{c}6 \\
.090 \\
.0057 \\
6.39 \\
.090 \\
.17 \\
-1.67 \\
-.470\end{array}$ & $\begin{array}{l}10 \\
.09 \\
.014 \\
15.9 \\
.09 \\
.99 \\
5.40 \\
2.14\end{array}$ & $\begin{array}{l}6 \\
.058 \\
.0017 \\
2.89 \\
.058 \\
.03 \\
2.50 \\
1.15\end{array}$ & $\begin{array}{l}10 \\
.06 \\
.013 \\
19.6 \\
.06 \\
1.46 \\
4.10 \\
2.14\end{array}$ \\
\hline \multicolumn{11}{|l|}{ ND PC-8 } \\
\hline 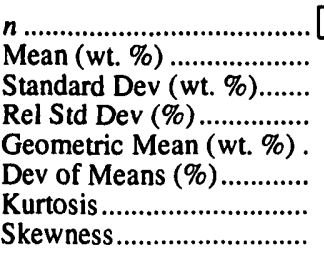 & $\begin{array}{l}3 \\
.67 \\
0 \\
0 \\
.67 \\
0 \\
\text { ERR } \\
\text { ERR }\end{array}$ & $\begin{array}{c}7 \\
.65 \\
.068 \\
10.4 \\
.65 \\
.47 \\
1.90 \\
-.0112\end{array}$ & $\begin{array}{c}6 \\
.400 \\
.0036 \\
.90 \\
.400 \\
0 \\
-1.94 \\
-.202\end{array}$ & $\begin{array}{c}10 \\
.35 \\
.088 \\
24.7 \\
.34 \\
3.40 \\
-.534 \\
-1.06\end{array}$ & $\begin{array}{l}10 \\
.49 \\
.042 \\
8.61 \\
.49 \\
.32 \\
-.793 \\
.975\end{array}$ & $\begin{array}{c}13 \\
.46 \\
.067 \\
14.6 \\
.46 \\
1.06 \\
.404 \\
-.533\end{array}$ & $\begin{array}{c}7 \\
.38 \\
.029 \\
7.73 \\
.38 \\
.26 \\
-2.14 \\
-.0612\end{array}$ & $\begin{array}{c}10 \\
.42 \\
.068 \\
16.2 \\
.42 \\
1.15 \\
-1.37 \\
-1.07\end{array}$ & $\begin{array}{l}7 \\
1.49 \\
.061 \\
4.07 \\
1.49 \\
.07 \\
-2.33 \\
-.114\end{array}$ & $\begin{array}{l}10 \\
1.4 \\
.12 \\
8.06 \\
1.4 \\
.31 \\
.515 \\
-.935\end{array}$ \\
\hline
\end{tabular}


Appendix 2. Statistical parameters for the data in appendix $1-$ Continued.

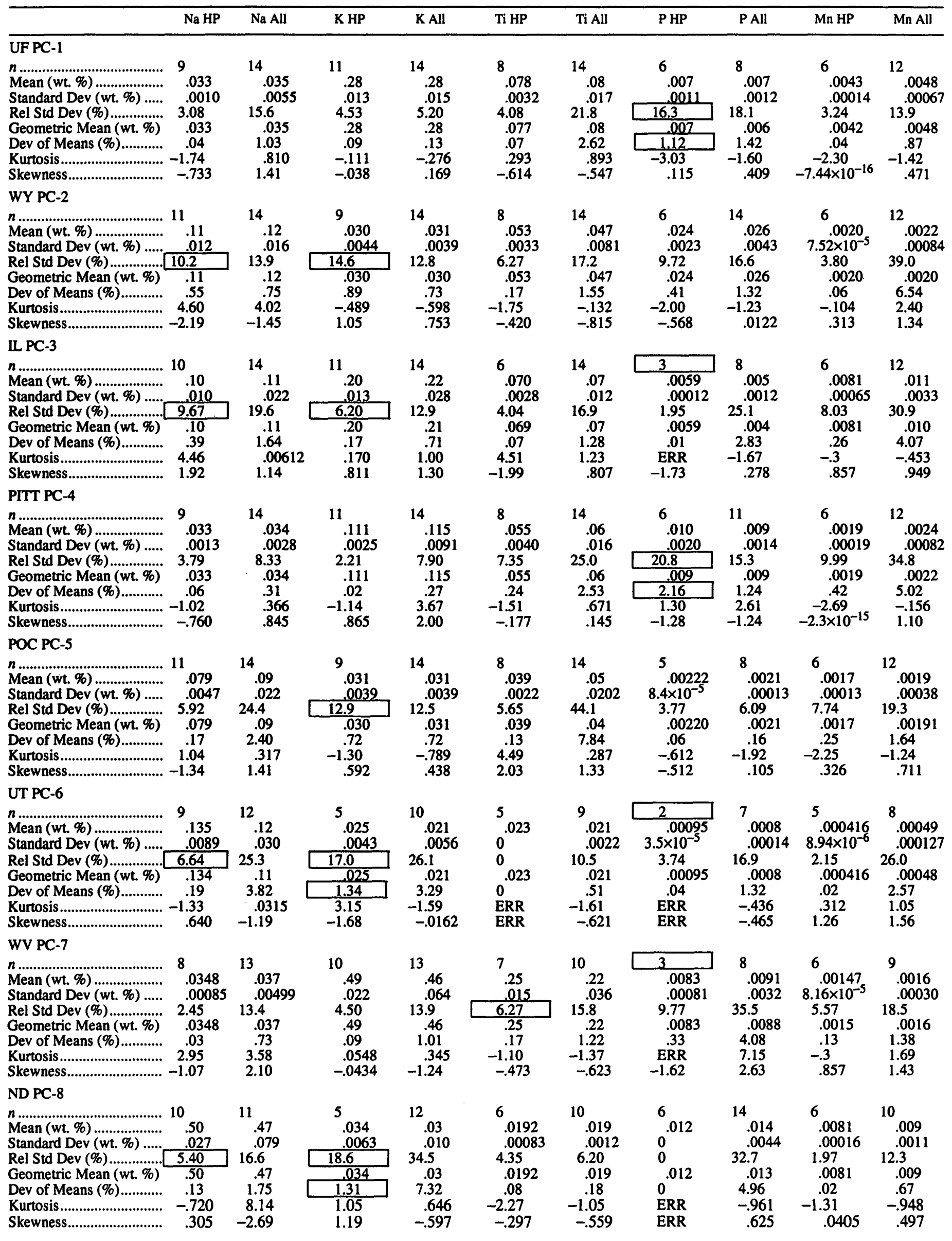


Appendix 2. Statistical parameters for the data in appendix $1-$ Continued.

\begin{tabular}{|c|c|c|c|c|c|c|c|c|c|}
\hline & Li HP & $\mathrm{Be} \mathrm{HP}$ & Be All & B HP & B All & Sc HP & Sc All & V HP & V All \\
\hline 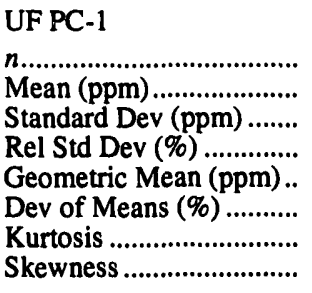 & $\begin{array}{c}6 \\
14.8 \\
0 \\
0 \\
14.8 \\
0 \\
-3.33 \\
1.37\end{array}$ & $\begin{array}{l}6 \\
1.5 \\
0 \\
0 \\
1.5 \\
0 \\
\text { ERR } \\
\text { ERR }\end{array}$ & $\begin{array}{l}9 \\
1.5 \\
.1 \\
6.82 \\
1.5 \\
.23 \\
9.00 \\
-3.00\end{array}$ & $\begin{array}{c}3 \\
38 \\
9.4 \\
24.5 \\
38 \\
1.92 \\
\text { ERR } \\
1.37\end{array}$ & $\begin{array}{c}6 \\
34 \\
12 \\
35.3 \\
32 \\
5.71 \\
-1.67 \\
.127\end{array}$ & $\begin{array}{l}6 \\
3.99 \\
.094 \\
2.37 \\
3.99 \\
.02 \\
-.384 \\
.863\end{array}$ & $\begin{array}{c}9 \\
3.4 \\
.99 \\
29.4 \\
3.2 \\
5.19 \\
-.302 \\
-1.142\end{array}$ & $\begin{array}{c}6 \\
26.5 \\
.55 \\
2.07 \\
26.5 \\
.02 \\
-3.33 \\
0\end{array}$ & $\begin{array}{l}12 \\
28 \\
9.6 \\
34.9 \\
26 \\
5.99 \\
-.301 \\
.448\end{array}$ \\
\hline 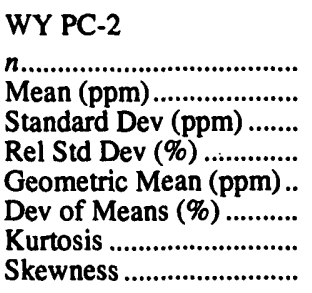 & $\begin{array}{l}6 \\
4.0 \\
.11 \\
2.85 \\
4.0 \\
.03 \\
-2.14 \\
.357\end{array}$ & \begin{tabular}{|l|}
3 \\
.25 \\
.01 \\
4.0 \\
.250 \\
.000534 \\
ERR \\
$1.46 \times 10^{-17}$
\end{tabular} & $\begin{array}{c}9 \\
.22 \\
.056 \\
25.9 \\
.21 \\
3.53 \\
-1.68 \\
-.817\end{array}$ & $\begin{array}{l}3 \\
96 \\
13 \\
13.7 \\
96 \\
.62 \\
\text { ERR } \\
.966\end{array}$ & $\begin{array}{l}6 \\
83 \\
17 \\
21.5 \\
82 \\
1.74 \\
.0757 \\
.724\end{array}$ & $\begin{array}{l}6 \\
1.66 \\
.034 \\
2.05 \\
1.66 \\
.02 \\
-1.78 \\
-.479\end{array}$ & $\begin{array}{c}9 \\
1.5 \\
.23 \\
14.6 \\
1.5 \\
1.17 \\
4.54 \\
-2.09\end{array}$ & $\begin{array}{c}6 \\
14 \\
.00 \\
0 \\
14 \\
0 \\
\text { ERR } \\
\text { ERR }\end{array}$ & $\begin{array}{l}12 \\
13 \\
2.8 \\
22.1 \\
12 \\
2.59 \\
-.344 \\
-.624\end{array}$ \\
\hline 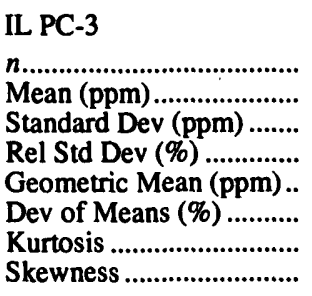 & $\begin{array}{l}6 \\
7.8 \\
.19 \\
2.41 \\
7.8 \\
.02 \\
-.446 \\
-.668\end{array}$ & \begin{tabular}{|l|}
3 \\
.76 \\
.017 \\
2.3 \\
.7599 \\
.000172 \\
ERR \\
1.73
\end{tabular} & $\begin{array}{c}9 \\
.8 \\
.16 \\
19.6 \\
.8 \\
1.62 \\
.109 \\
.949\end{array}$ & $\begin{array}{c}3 \\
160 \\
2.9 \\
1.80 \\
160 \\
.01 \\
\text { ERR } \\
-1.73\end{array}$ & $\begin{array}{c}6 \\
140 \\
23 \\
16.5 \\
140 \\
1.17 \\
-2.43 \\
-.272\end{array}$ & $\begin{array}{l}6 \\
2.65 \\
.094 \\
3.55 \\
2.64 \\
.05 \\
-2.01 \\
.577\end{array}$ & $\begin{array}{l}9 \\
2.6 \\
.11 \\
4.04 \\
2.6 \\
.07 \\
-1.39 \\
.429\end{array}$ & $\begin{array}{c}6 \\
35 \\
3.3 \\
9.48 \\
34 \\
.37 \\
-2.08 \\
.309\end{array}$ & $\begin{array}{l}12 \\
36 \\
11 \\
30.7 \\
35 \\
4.19 \\
.239 \\
.837\end{array}$ \\
\hline 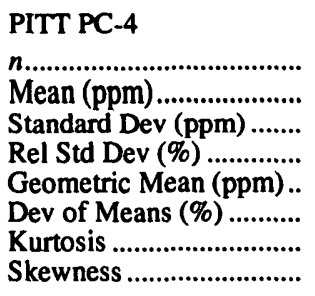 & $\begin{array}{l}6 \\
8.6 \\
.36 \\
4.17 \\
8.6 \\
.07 \\
.521 \\
.673\end{array}$ & $\begin{array}{c}3 \\
.77 \\
.012 \\
1.51 \\
.77 \\
.01 \\
\text { ERR } \\
1.73\end{array}$ & $\begin{array}{c}9 \\
.9 \\
.21 \\
23.5 \\
.9 \\
2.28 \\
-1.43 \\
.911\end{array}$ & $\begin{array}{c}3 \\
47.8 \\
.95 \\
1.99 \\
47.8 \\
.01 \\
\text { ERR } \\
.158\end{array}$ & $\begin{array}{c}6 \\
50 \\
2.4 \\
4.84 \\
50 \\
.10 \\
-1.35 \\
.613\end{array}$ & $\begin{array}{l}6 \\
2.53 \\
.055 \\
2.18 \\
2.53 \\
.02 \\
-1.36 \\
.583\end{array}$ & $\begin{array}{c}9 \\
2.3 \\
.36 \\
15.6 \\
2.3 \\
1.20 \\
-1.03 \\
-.962\end{array}$ & $\begin{array}{c}6 \\
16 \\
1.1 \\
6.85 \\
16 \\
.20 \\
-3.33 \\
0\end{array}$ & $\begin{array}{l}12 \\
17 \\
4.7 \\
27.42 \\
17 \\
3.15 \\
.710 \\
1.17\end{array}$ \\
\hline 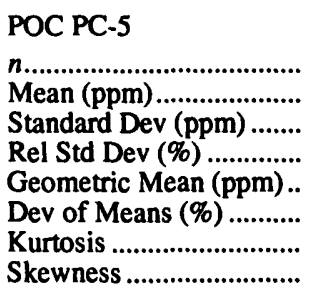 & $\begin{array}{l}6 \\
5.6 \\
.27 \\
4.78 \\
5.6 \\
.10 \\
-1.88 \\
-.960\end{array}$ & $\begin{array}{l}6 \\
.80 \\
0 \\
0 \\
.80 \\
0 \\
-3.33 \\
1.37\end{array}$ & $\begin{array}{c}9 \\
.76 \\
.077 \\
10.2 \\
.75 \\
.52 \\
3.24 \\
-1.89\end{array}$ & $\begin{array}{c}3 \\
13.1 \\
.64 \\
4.86 \\
13.1 \\
.08 \\
\text { ERR } \\
1.73\end{array}$ & $\begin{array}{c}6 \\
15 \\
2.6 \\
16.8 \\
15 \\
1.17 \\
-1.34 \\
.487\end{array}$ & $\begin{array}{l}6 \\
1.78 \\
.023 \\
1.32 \\
1.78 \\
.01 \\
-2.41 \\
-.245\end{array}$ & $\begin{array}{c}9 \\
1.6 \\
.21 \\
13.0 \\
1.6 \\
.83 \\
-.787 \\
-1.07\end{array}$ & $\begin{array}{c}6 \\
11.5 \\
.55 \\
4.76 \\
11.5 \\
.09 \\
-3.33 \\
0\end{array}$ & $\begin{array}{c}12 \\
12 \\
4.4 \\
36.1 \\
11 \\
6.08 \\
.210 \\
.740\end{array}$ \\
\hline \multicolumn{10}{|l|}{ UT PC-6 } \\
\hline 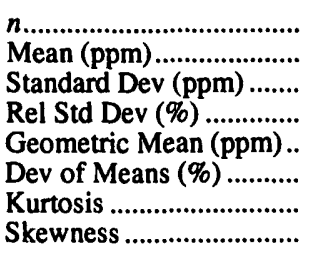 & $\begin{array}{l}5 \\
5.3 \\
.25 \\
4.72 \\
5.3 \\
.09 \\
-3.33 \\
-.609\end{array}$ & $\begin{array}{l}2 \\
.125 \\
.0071 \\
5.66 \\
.125 \\
.08 \\
\text { ERR } \\
\text { ERR }\end{array}$ & $\begin{array}{l}10 \\
.16 \\
.039 \\
24.5 \\
.16 \\
2.45 \\
.312 \\
1.19\end{array}$ & $\begin{array}{c}3 \\
127 \\
5.2 \\
4.09 \\
127 \\
.05 \\
\text { ERR } \\
1.73\end{array}$ & $\begin{array}{c}3 \\
127 \\
5.2 \\
4.09 \\
127 \\
\text {.05 } \\
\text { ERR } \\
1.73\end{array}$ & $\begin{array}{l}6 \\
.78 \\
.037 \\
4.75 \\
.78 \\
.09 \\
-1.52 \\
-.145\end{array}$ & $\begin{array}{l}9 \\
.75 \\
.060 \\
8.04 \\
.75 \\
.30 \\
-.00338 \\
-.618\end{array}$ & $\begin{array}{l}5 \\
4.3 \\
.27 \\
6.27 \\
4.27 \\
.16 \\
-2.41 \\
-.166\end{array}$ & $\begin{array}{l}8 \\
4.05 \\
.38 \\
9.43 \\
4.03 \\
.39 \\
-1.55 \\
.185\end{array}$ \\
\hline \multicolumn{10}{|l|}{ WV PC-7 } \\
\hline 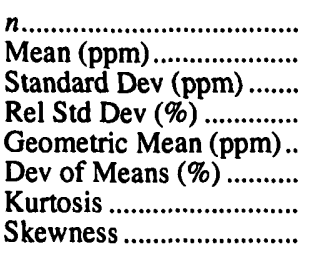 & $\begin{array}{l}6 \\
28 \\
1.0 \\
3.70 \\
28 \\
.06 \\
-3.33 \\
-7.7 \times 10^{-15}\end{array}$ & $\begin{array}{l}6 \\
2.0 \\
.11 \\
5.48 \\
2.0 \\
.13 \\
-3.33 \\
4.76 \times 10^{-18}\end{array}$ & $\begin{array}{c}12 \\
2.3 \\
.51 \\
22.0 \\
2.3 \\
2.10 \\
-1.53 \\
.746\end{array}$ & $\begin{array}{l}3 \\
56 \\
20 \\
35.9 \\
50 \\
4.25 \\
\text { ERR } \\
1.09\end{array}$ & $\begin{array}{l}6 \\
56 \\
24 \\
43.1 \\
50 \\
8.02 \\
-.851 \\
.686\end{array}$ & $\begin{array}{l}6 \\
7.5 \\
.14 \\
1.84 \\
7.5 \\
.01 \\
-1.95 \\
.474\end{array}$ & $\begin{array}{l}9 \\
7.13 \\
.62 \\
8.69 \\
7.11 \\
.36 \\
.154 \\
-1.26\end{array}$ & $\begin{array}{c}6 \\
43.3 \\
.82 \\
1.88 \\
43.3 \\
.01 \\
6.00 \\
2.449\end{array}$ & $\begin{array}{c}9 \\
39 \\
6.1 \\
15.4 \\
39 \\
1.17 \\
-.784 \\
-1.03\end{array}$ \\
\hline \multicolumn{10}{|l|}{ ND PC-8 } \\
\hline 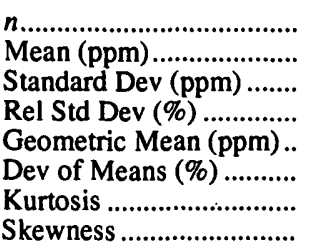 & $\begin{array}{l}6 \\
2.69 \\
.078 \\
2.88 \\
2.69 \\
.03 \\
6.00 \\
2.45\end{array}$ & $\begin{array}{l}2 \\
.175 \\
.0071 \\
4.04 \\
.175 \\
.04 \\
\text { ERR } \\
\text { ERR }\end{array}$ & $\begin{array}{c}10 \\
.22 \\
.054 \\
24.2 \\
.22 \\
2.42 \\
.0493 \\
1.09\end{array}$ & $\begin{array}{c}3 \\
79 \\
1.1 \\
1.38 \\
79 \\
.01 \\
\text { ERR } \\
1.73\end{array}$ & $\begin{array}{l}6 \\
73 \\
12 \\
17.0 \\
72 \\
1.52 \\
5.65 \\
-2.36\end{array}$ & $\begin{array}{l}3 \\
.80 \\
.049 \\
6.07 \\
.20 \\
.20 \\
-.267 \\
.231\end{array}$ & $\begin{array}{l}9 \\
.83 \\
.064 \\
7.71 \\
.83 \\
.26 \\
-.230 \\
.314\end{array}$ & $\begin{array}{l}6 \\
3.7 \\
.21 \\
5.80 \\
3.7 \\
.14 \\
-2.15 \\
-.232\end{array}$ & $\begin{array}{l}9 \\
3.6 \\
.18 \\
4.97 \\
3.6 \\
.11 \\
-1.19 \\
.440\end{array}$ \\
\hline
\end{tabular}


Appendix 2. Statistical parameters for the data in appendix 1 -Continued.

\begin{tabular}{|c|c|c|c|c|c|c|c|c|c|c|}
\hline & $\mathrm{Cr} \mathrm{HP}$ & Cr All & Co HP & Co All & Ni HP & Ni All & $\mathrm{Cu} \mathrm{HP}$ & $\mathrm{Cu}$ All & Zn HP & $\mathrm{Zn}$ All \\
\hline \multicolumn{11}{|l|}{ UF PC-1 } \\
\hline 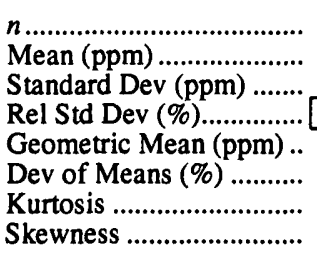 & \begin{tabular}{|c|}
12 \\
22 \\
2.6 \\
11.9 \\
22 \\
.62 \\
-.530 \\
.930
\end{tabular} & $\begin{array}{l}21 \\
23 \\
5.2 \\
22.8 \\
22 \\
2.20 \\
3.11 \\
1.53\end{array}$ & $\begin{array}{l}9 \\
5.2 \\
.22 \\
4.25 \\
5.2 \\
.08 \\
3.43 \\
-1.76\end{array}$ & $\begin{array}{c}15 \\
4.8 \\
.71 \\
14.7 \\
4.8 \\
1.22 \\
2.20 \\
-1.70\end{array}$ & $\begin{array}{l}12 \\
15 \\
2.3 \\
15.5 \\
15 \\
1.04 \\
4.65 \\
1.36\end{array}$ & $\begin{array}{l}21 \\
17 \\
5.0 \\
28.8 \\
17 \\
3.62 \\
.00992 \\
1.03\end{array}$ & $\begin{array}{c}9 \\
18.9 \\
.98 \\
5.18 \\
18.9 \\
.12 \\
1.49 \\
-.553\end{array}$ & $\begin{array}{l}18 \\
18 \\
1.4 \\
7.37 \\
18 \\
.26 \\
-.783 \\
-.401\end{array}$ & $\begin{array}{l}12 \\
20 \\
1.8 \\
9.10 \\
20 \\
.36 \\
2.36 \\
1.30\end{array}$ & $\begin{array}{l}18 \\
24 \\
7.0 \\
29.0 \\
23 \\
3.63 \\
-.238 \\
.997\end{array}$ \\
\hline \multicolumn{11}{|c|}{ WY PC-2 } \\
\hline $\begin{array}{l}\text { Mean (ppm) } \\
\text { Standard Dev (ppm) ........ } \\
\text { Rel Std Dev (\%)............. } \\
\text { Geometric Mean (ppm).. } \\
\text { Dev of Means (\%) } \\
\text { Kurtosis } \\
\text { Skewness }\end{array}$ & \begin{tabular}{|l|}
$\begin{array}{c}11 \\
6.5 \\
.69\end{array}$ \\
10.6 \\
6.5 \\
.47 \\
3.52 \\
1.80
\end{tabular} & $\begin{array}{l}20 \\
6 \\
1.3 \\
21.0 \\
6 \\
2.42 \\
1.55 \\
-.209\end{array}$ & $\begin{array}{l}9 \\
1.65 \\
.088 \\
5.32 \\
1.65 \\
.13 \\
.326 \\
.112\end{array}$ & $\begin{array}{c}12 \\
1.6 \\
.21 \\
13.7 \\
1.5 \\
1.02 \\
3.71 \\
-1.71\end{array}$ & $\begin{array}{c}12 \\
4.7 \\
.50 \\
10.8 \\
4.6 \\
.56 \\
-.106 \\
-.583\end{array}$ & $\begin{array}{c}18 \\
5.3 \\
1.4 \\
25.9 \\
5.2 \\
2.70 \\
2.58 \\
1.69\end{array}$ & $\begin{array}{c}9 \\
13.0 \\
.79 \\
6.08 \\
12.9 \\
.16 \\
-1.35 \\
-.001\end{array}$ & $\begin{array}{l}18 \\
12.7 \\
3.3 \\
26.2 \\
12.2 \\
4.39 \\
1.22 \\
-.836\end{array}$ & $\begin{array}{l}12 \\
11.0 \\
.96 \\
8.73 \\
10.9 \\
.34 \\
.343 \\
.593\end{array}$ & $\begin{array}{l}15 \\
14 \\
6.2 \\
44.8 \\
13 \\
7.21 \\
2.08 \\
1.83\end{array}$ \\
\hline \multicolumn{11}{|c|}{ IL PC-3 } \\
\hline n & 12 & 21 & 9 & 12 & 11 & 21 & 9 & 18 & 9 & 18 \\
\hline 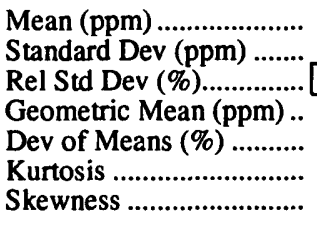 & $\begin{array}{c}36 \\
5.2 \\
14.6 \\
35 \\
.96 \\
-1.38 \\
.584\end{array}$ & $\begin{array}{l}38 \\
7.7 \\
19.9 \\
38 \\
1.76 \\
.582 \\
.992\end{array}$ & $\begin{array}{l}4.4 \\
.18 \\
4.35 \\
4.4 \\
.08 \\
-.636 \\
.867\end{array}$ & $\begin{array}{c}4.2 \\
.37 \\
8.87 \\
4.2 \\
.39 \\
1.25 \\
-1.12\end{array}$ & $\begin{array}{l}19 \\
2.5 \\
12.9 \\
19 \\
.78 \\
2.74 \\
.172\end{array}$ & $\begin{array}{l}24 \\
6.7 \\
28.2 \\
23 \\
3.67 \\
-.823 \\
.690\end{array}$ & $\begin{array}{c}10.1 \\
.78 \\
7.74 \\
10.1 \\
.27 \\
-.211 \\
-.411\end{array}$ & $\begin{array}{l}11 \\
1.9 \\
17.7 \\
11 \\
1.36 \\
.569 \\
1.19\end{array}$ & $\begin{array}{c}200 \\
25 \\
12.3 \\
200 \\
.68 \\
.393 \\
.486\end{array}$ & $\begin{array}{l}190 \\
60 \\
32.3 \\
180 \\
5.37 \\
-.0399 \\
.320\end{array}$ \\
\hline \multicolumn{11}{|c|}{ PITT PC-4 } \\
\hline$n$ & 12 & 21 & 9 & 12 & 11 & 20 & 9 & 18 & 11 & 18 \\
\hline 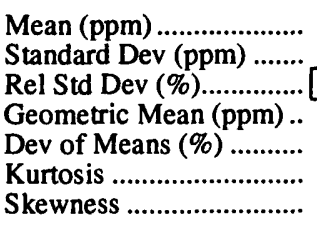 & \begin{tabular}{|l}
16 \\
1.6 \\
10.3 \\
16 \\
.49 \\
-.529 \\
.248
\end{tabular} & $\begin{array}{l}16 \\
4.7 \\
28.9 \\
16 \\
4.78 \\
.905 \\
.00908\end{array}$ & $\begin{array}{l}2.6 \\
.10 \\
4.03 \\
2.6 \\
.07 \\
.280 \\
-1.12\end{array}$ & $\begin{array}{l}2.6 \\
.15 \\
5.95 \\
2.6 \\
.17 \\
-.222 \\
-.499\end{array}$ & $\begin{array}{l}9.2 \\
.89 \\
9.66 \\
9.2 \\
.40 \\
2.16 \\
1.30\end{array}$ & $\begin{array}{l}11 \\
2.5 \\
22.8 \\
11 \\
2.34 \\
-.170 \\
.826\end{array}$ & $\begin{array}{c}5.8 \\
.40 \\
6.95 \\
5.8 \\
.21 \\
-1.77 \\
.221\end{array}$ & $\begin{array}{l}7 \\
1.6 \\
24.2 \\
6 \\
2.45 \\
.548 \\
1.33\end{array}$ & $\begin{array}{l}8.3 \\
.83 \\
9.91 \\
8.3 \\
.41 \\
4.78 \\
1.92\end{array}$ & $\begin{array}{l}13 \\
7.3 \\
56.4 \\
11 \\
12.3 \\
1.87 \\
1.63\end{array}$ \\
\hline \multicolumn{11}{|c|}{ POC PC-5 } \\
\hline $\begin{array}{l}\text { Mean (ppm) ... } \\
\text { Standard Dev (ppm) ........ } \\
\text { Rel Std Dev (\%)]........... } \\
\text { Geometric Mean (ppm) .. } \\
\text { Dev of Means (\%) } \\
\text { Kurtosis } \\
\text { Skewness }\end{array}$ & \begin{tabular}{|c|}
12 \\
10 \\
1.4 \\
14.1 \\
10 \\
.85 \\
-.408 \\
1.06
\end{tabular} & $\begin{array}{l}21 \\
10 \\
3.2 \\
32.3 \\
10 \\
5.38 \\
.782 \\
.592\end{array}$ & $\begin{array}{l}9 \\
3.9 \\
.13 \\
3.20 \\
3.9 \\
.05 \\
-1.45 \\
.058\end{array}$ & $\begin{array}{l}12 \\
3.6 \\
.65 \\
18.1 \\
3.5 \\
1.83 \\
.553 \\
-1.43\end{array}$ & $\begin{array}{c}12 \\
7.6 \\
.79 \\
10.4 \\
7.6 \\
.48 \\
.160 \\
.611\end{array}$ & $\begin{array}{c}20 \\
8 \\
1.8 \\
21.5 \\
8 \\
2.07 \\
-.251 \\
.873\end{array}$ & $\begin{array}{c}9 \\
14 \\
1.9 \\
14.1 \\
13 \\
.85 \\
-1.75 \\
.725\end{array}$ & $\begin{array}{l}18 \\
16 \\
4.1 \\
25.4 \\
16 \\
2.76 \\
1.84 \\
1.29\end{array}$ & $\begin{array}{c}12 \\
5 \\
1.0 \\
19.8 \\
5 \\
1.75 \\
.562 \\
.725\end{array}$ & $\begin{array}{l}15 \\
7 \\
3.9 \\
56.5 \\
6 \\
12.29 \\
.597 \\
1.48\end{array}$ \\
\hline \multicolumn{11}{|c|}{ UT PC-6 } \\
\hline 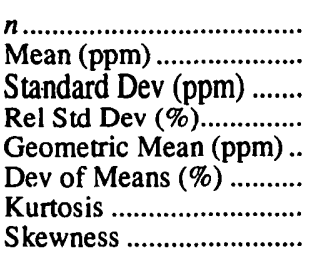 & $\begin{array}{l}8 \\
5.2 \\
.31 \\
6.04 \\
5.1 \\
.16 \\
.874 \\
-.293\end{array}$ & $\begin{array}{c}11 \\
5.1 \\
.48 \\
9.44 \\
5.0 \\
.45 \\
3.11 \\
-1.54\end{array}$ & $\begin{array}{l}8 \\
.93 \\
.072 \\
7.74 \\
.93 \\
.27 \\
-1.18 \\
-.645\end{array}$ & $\begin{array}{l}11 \\
.9 \\
.15 \\
17.5 \\
.8 \\
1.55 \\
-1.03 \\
-.705\end{array}$ & $\begin{array}{l}7 \\
3.4 \\
.17 \\
4.99 \\
3.4 \\
.11 \\
-.638 \\
.169\end{array}$ & $\begin{array}{l}13 \\
3.9 \\
.67 \\
16.92 \\
3.9 \\
1.25 \\
-.704 \\
.872\end{array}$ & $\begin{array}{l}5 \\
4.1 \\
.21 \\
5.11 \\
4.1 \\
.11 \\
-1.96 \\
-.236\end{array}$ & $\begin{array}{l}11 \\
5 \\
2.2 \\
45.9 \\
4 \\
9.49 \\
-.927 \\
.829\end{array}$ & $\begin{array}{c}8 \\
6 \\
1.1 \\
18.8 \\
6 \\
1.53 \\
-1.51 \\
.401\end{array}$ & $\begin{array}{l}8 \\
6 \\
1.1 \\
19.2 \\
6 \\
1.53 \\
-1.51 \\
.401\end{array}$ \\
\hline \multicolumn{11}{|l|}{ WV PC-7 } \\
\hline $\begin{array}{l}\text { Mean (ppm) .............. } \\
\text { Standard Dev (ppm) ....... } \\
\text { Rel Std Dev (\%)............ } \\
\text { Geometric Mean (ppm).. } \\
\text { Dev of Means (\%) } \\
\text { Kurtosis } \\
\text { Skewness }\end{array}$ & $\begin{array}{l}12 \\
40 \\
3.8 \\
9.51 \\
40 \\
.41 \\
-.935 \\
.516\end{array}$ & $\begin{array}{l}15 \\
40 \\
3.7 \\
9.34 \\
40 \\
.40 \\
-.915 \\
.330\end{array}$ & $\begin{array}{l}9 \\
7.8 \\
.34 \\
4.33 \\
7.8 \\
.08 \\
.0131 \\
.805\end{array}$ & $\begin{array}{l}12 \\
7.4 \\
.79 \\
10.7 \\
7.4 \\
.57 \\
.765 \\
-1.15\end{array}$ & $\begin{array}{l}12 \\
16 \\
1.2 \\
7.43 \\
16 \\
.26 \\
.325 \\
-.0667\end{array}$ & $\begin{array}{l}18 \\
17 \\
2.2 \\
12.99 \\
17 \\
.75 \\
1.46 \\
1.08\end{array}$ & $\begin{array}{c}9 \\
21 \\
2.1 \\
10.0 \\
21 \\
.44 \\
-.0445 \\
.710\end{array}$ & $\begin{array}{l}15 \\
22 \\
5.4 \\
24.7 \\
21 \\
2.88 \\
-.300 \\
.518\end{array}$ & $\begin{array}{l}12 \\
12 \\
1.1 \\
9.17 \\
12 \\
.38 \\
-1.01 \\
.425\end{array}$ & $\begin{array}{l}15 \\
12 \\
1.5 \\
12.52 \\
12 \\
\quad .75 \\
-.5667 \\
-.412\end{array}$ \\
\hline \multicolumn{11}{|c|}{ ND PC-8 } \\
\hline 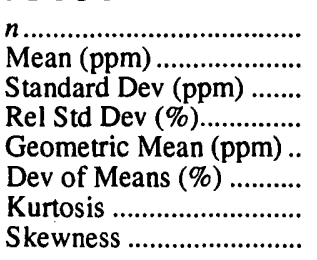 & $\begin{array}{c}12 \\
2.4 \\
.21 \\
8.79 \\
2.4 \\
.35 \\
-1.01 \\
.437\end{array}$ & $\begin{array}{l}15 \\
2.4 \\
.19 \\
7.84 \\
2.4 \\
.28 \\
-.482 \\
-.415\end{array}$ & $\begin{array}{c}3 \\
.78 \\
.021 \\
2.75 \\
.78 \\
.02 \\
\text { ERR } \\
1.32\end{array}$ & $\begin{array}{c}9 \\
.7 \\
.15 \\
20.0 \\
.7 \\
1.89 \\
-1.10 \\
-.181\end{array}$ & $\begin{array}{c}9 \\
1.5 \\
.37 \\
24.3 \\
1.5 \\
2.32 \\
3.38 \\
1.63\end{array}$ & $\begin{array}{c}15 \\
2 \\
2.3 \\
91.4 \\
2 \\
23.46 \\
9.67 \\
2.98\end{array}$ & $\begin{array}{c}8 \\
4.2 \\
.91 \\
22.0 \\
4.1 \\
2.10 \\
-1.55 \\
.41\end{array}$ & $\begin{array}{c}15 \\
6 \\
2.9 \\
49.6 \\
5 \\
10.7 \\
.0149 \\
1.08\end{array}$ & $\begin{array}{c}12 \\
5.2 \\
.47 \\
9.06 \\
5.1 \\
.37 \\
-1.28 \\
.215\end{array}$ & $\begin{array}{c}15 \\
5.1 \\
.57 \\
11.0 \\
5.1 \\
.58 \\
-.438 \\
-.163\end{array}$ \\
\hline
\end{tabular}


Appendix 2. Statistical parameters for the data in appendix $1-$ Continued.

\begin{tabular}{|c|c|c|c|c|c|c|c|c|c|c|}
\hline & Ga HP & Ga All & Ge HP & Ge All & As HP & As All & Se HP & Se All & Rb HP & $\mathbf{R b}$ All \\
\hline \multicolumn{11}{|l|}{ UF PC-1 } \\
\hline n & 3 & 9 & 3 & 9 & 6 & 9 & 6 & 6 & 9 & 12 \\
\hline Mean (ppm) & 5.34 & 7 & 4.35 & 3.9 & 16.7 & 21 & 1.9 & 1.9 & 21 & 21 \\
\hline Standard Dev (ppm)......... & 1.21 & 2.3 & .053 & .48 & .59 & 8.0 & 27 & .27 & 1.2 & 1.2 \\
\hline Rel Std Dev (\%) & 2.26 & 32.2 & 1.22 & 12.4 & 3.52 & 37.5 & 14.1 & 14.1 & 5.93 & 5.98 \\
\hline Geometric Mean (ppm) .. & 5.3 & 7 & 4.35 & 3.8 & 16.6 & 20 & 1.9 & 1.9 & 21 & 21 \\
\hline Dev of Means $(\%)$................. & .02 & 4.15 & 0 & .73 & .05 & 5.23 & .87 & .87 & .16 & .16 \\
\hline 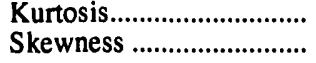 & $\begin{array}{l}\text { ERR } \\
-.49\end{array}$ & $\begin{array}{l}-.260 \\
1.16\end{array}$ & $\begin{array}{r}\text { ERR } \\
-1.46\end{array}$ & $\begin{array}{l}-.487 \\
-.698\end{array}$ & $\begin{array}{l}-.428 \\
1.0\end{array}$ & $\begin{array}{l}1.57 \\
1.62\end{array}$ & $\begin{array}{r}.556 \\
-.368\end{array}$ & $\begin{array}{r}.556 \\
-.368\end{array}$ & $\begin{array}{l}-.545 \\
-.192\end{array}$ & $\begin{array}{l}-.629 \\
-.031\end{array}$ \\
\hline \multicolumn{11}{|l|}{ WY PC-2 } \\
\hline n & 3 & 9 & 3 & 3 & 6 & 6 & 6 & 6 & 6 & 9 \\
\hline Mean (ppm) & 1.9 & 2.4 & .36 & .36 & 3.0 & 3.0 & 2.0 & 2.0 & 2.7 & 6 \\
\hline Standard Dev (ppm)........ & .12 & .70 & 0 & 0 & .71 & .71 & .55 & .55 & .94 & 5.3 \\
\hline Rel Std Dev $(\%)$ & 6.15 & 28.6 & & 0 & 23.4 & 23.4 & 27.9 & 27.9 & 35.3 & 86.9 \\
\hline Geometric Mean (ppm).. & 1.9 & 2.4 & .36 & .36 & 2.9 & 2.9 & 1.9 & 1.9 & 2.5 & 4 \\
\hline Dev of Means (\%) ............. & .12 & 3.18 & 0 & 0 & 2.59 & 2.64 & 3.06 & 3.06 & 5.60 & 40.76 \\
\hline 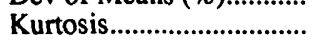 & ERR & 2.46 & ERR & ERR & -.558 & -.558 & -1.17 & -1.17 & -3.16 & -1.33 \\
\hline 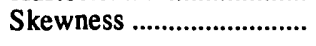 & 1.508 & 1.55 & -2.45 & -2.45 & -.523 & -.523 & .953 & .953 & .0580 & .877 \\
\hline \multicolumn{11}{|l|}{ IL PC-3 } \\
\hline 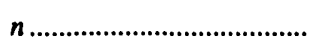 & 3 & 9 & 3 & 9 & 6 & 6 & 6 & 6 & 9 & 12 \\
\hline Mean (ppm) & 3.57 & 5 & 8.4 & 9 & 4.2 & 4.2 & 4.2 & 4.2 & 15.5 & 17 \\
\hline Standard Dev (ppm).......... & .107 & 1.6 & .27 & 1.4 & .53 & .53 & 45 & .45 & .78 & 2.4 \\
\hline Rel Std Dev (\%)................... & 2.99 & 31.4 & 3.21 & 16.1 & 12.6 & 12.6 . & 10.7 & 10.7 & 5.00 & 14.5 \\
\hline Geometric Mean (ppm)... & 3.57 & 5 & 8.4 & 9 & 4.2 & 4.2 & 4.2 & 4.2 & 15.5 & 16 \\
\hline Dev of Means $(\%)$................. & .03 & 4.03 & .03 & 1.04 & .67 & .67 & .45 & .45 & .11 & .87 \\
\hline Kurtosis................................... & ERR & .440 & ERR & 3.82 & -2.06 & -2.06 & 3.44 & 3.44 & 2.55 & 1.70 \\
\hline 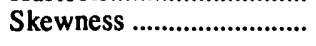 & -1.71 & 1.14 & -1.293 & 1.69 & -.051 & -.051 & 1.72 & i.72 & 1.40 & 1.65 \\
\hline \multicolumn{11}{|c|}{ PITT PC-4 } \\
\hline$n$ & 3 & 9 & 3 & 7 & 6 & 9 & 6 & 6 & 9. & 12 \\
\hline Mean (ppm) & 3.3 & 4 & 1.2 & 1.5 & 8.0 & 11 & 1.6 & 1.6 & 8.3 & 8.2 \\
\hline Standard Dev (ppm).......... & .14 & 1.0 & .13 & .68 & .56 & 4.6 & .15 & .15 & .82 & .71 \\
\hline 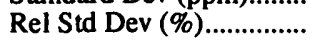 & 4.27 & 22.7 & 10.5 & 46.7 & 6.92 & 41.8 & 9.64 & 9.64 & 9.83 & 8.64 \\
\hline Geometric Mean (ppm).. & 3.3 & 4 & 1.2 & 1.4 & 8.0 & 10 & 1.6 & 1.6 & 8.3 & 8.2 \\
\hline Dev of Means (\%) & & 2.43 & .37 & 6.69 & .21 & 7.15 & .39 & .39 & .44 & .34 \\
\hline 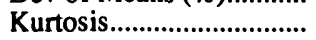 & ERR & -1.44 & ERR & 6.59 & .001 & -.937 & 1.23 & 1.23 & -1.02 & -.484 \\
\hline 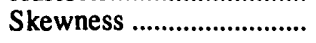 & 1.26 & -.0535 & .87 & 2.55 & -1.15 & 1.00 & -.087 & -.087 & -.312 & .058 \\
\hline \multicolumn{11}{|l|}{ POC PC-5 } \\
\hline 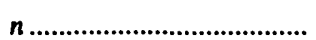 & 3 & 9 & 3 & 6 & 6 & 9 & 6 & 6 & 6 & 9 \\
\hline Mean (ppm) & 1.8 & 2.6 & .29 & .4 & 10.1 & 12 & 2.7 & 2.7 & 2.2 & 3 \\
\hline Standard Dev (ppm) & .10 & .90 & .065 & .10 & .52 & 2.8 & 30 & .30 & .20 & 1.3 \\
\hline Rel Std Dev $(\%)$ & 5.31 & 34.8 & 23.2 & 28.0 & 5.16 & 24.2 & 11.0 & 11.0 & 8.76 & 41.8 \\
\hline Geometric Mean (ppm) .. & 1.8 & 2.5 & 28 & .4 & 10.1 & 11 & 2.7 & 2.7 & 2.2 & 3 \\
\hline 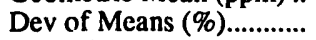 & .09 & 5.08 & 1.76 & 3.78 & .11 & 2.18 & .52 & .52 & .30 & 7.17 \\
\hline 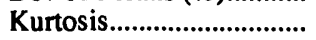 & ERR & -.660 & ERR & -1.81 & -2.57 & 3.74 & -1.34 & -1.34 & 4.68 & -1.03 \\
\hline 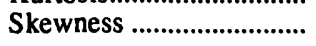 & -.158 & .936 & 1.06 & -.415 & -.192 & 1.99 & -.173 & -.173 & 2.12 & .980 \\
\hline \multicolumn{11}{|l|}{ UT PC-6 } \\
\hline n & 3 & 6 & 3 & 3 & 4 & 4 & 6 & 6 & 5 & 8 \\
\hline Mean (ppm) & 1.00 & 1.1 & .23 & .23 & .45 & .45 & 1.2 & 1.2 & 1.02 & 1.6 \\
\hline Standard Dev (ppm)......... & .051 & .24 & .033 & .033 & .082 & .082 & .12 & .12 & .057 & .90 \\
\hline Rel Std Dev (\%)................... & 5.20 & 21.1 & 14.7 & 14.7 & 19.7 & 19.7 & 10.4 & 10.4 & 5.64 & 55.2 \\
\hline Geometric Mean (ppm) .. & .99 & 1.1 & .22 & .22 & 44 & .44 & 1.2 & 1.2 & 1.02 & 1.5 \\
\hline Dev of Means $(\%)$ & .09 & 1.74 & .71 & .71 & 1.65 & 1.65 & .46 & .46 & .13 & 12.68 \\
\hline 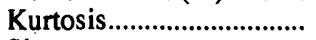 & ERR & -.213 & ERR & ERR & 1.23 & 1.2 & -1.97 & -1.97 & -.628 & -1.02 \\
\hline 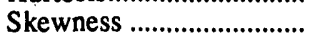 & 1.73 & 1.08 & -1.55 & -1.55 & -1.34 & -1.34 & -.178 & -.178 & .138 & 1.00 \\
\hline \multicolumn{11}{|l|}{ WV PC-7 } \\
\hline 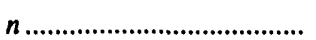 & 3 & 6 & 3 & 5 & 6 & 6 & 5 & 6 & 9 & 12 \\
\hline Mean (ppm) & 9.4 & 11 & 1.67 & 1.5 & 6.4 & 6.4 & 5.6 & 5.8 & 36 & 38 \\
\hline Standard Dev (ppm)......... & .44 & 1.5 & .058 & .29 & .81 & .81 & .30 & .59 & 6.1 & 5.7 \\
\hline Rel Std Dev (\%)................ & 4.68 & 14.0 & 3.46 & 19.9 & 12.6 & 12.6 & 5.30 & 10.1 & 16.7 & 15.2 \\
\hline Geometric Mean (ppm)... & 9.4 & 10 & 1.67 & 1.4 & 6.4 & 6.4 & 5.6 & 5.8 & 36 & 37 \\
\hline Dev of Means $(\%)$............... & .07 & .79 & .04 & 1.68 & .67 & .67 & .11 & .40 & 1.25 & 1.13 \\
\hline Kurtosis.............................. & ERR & .605 & ERR & -2.85 & -1.11 & -1.11 & 2.86 & 2.06 & -1.48 & -1.26 \\
\hline 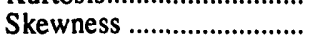 & -1.72 & .890 & -1.73 & -.590 & -.306 & -.306 & 1.40 & 1.54 & .090 & -.469 \\
\hline \multicolumn{11}{|l|}{ ND PC-8 } \\
\hline$n$ & 3 & 6 & 3 & 3 & 4 & 5 & 6 & 6 & 5 & 8 \\
\hline Mean $(\mathrm{ppm})$ & 1.16 & 1.4 & .37 & .37 & 2.4 & 2.0 & .59 & .59 & 1.2 & 2 \\
\hline Standard Dev (ppm)......... & .04 & .34 & .045 & .045 & .51 & .87 & .042 & .042 & .27 & 1.5 \\
\hline Rel Std Dev (\%) .................. & 3.47 & 23.4 & 12.3 & 12.3 & 21.4 & 42.5 & 7.04 & 7.04 & 21.0 & 69.6 \\
\hline Geometric Mean (ppm).. & 1.16 & 1.4 & .36 & .36 & 2.3 & 1.8 & .59 & .59 & 1.2 & 2 \\
\hline Dev of Means (\%)................ & .04 & 2.25 & .51 & .51 & 2.15 & 11.43 & .22 & .22 & 1.92 & 22.09 \\
\hline Kurtosis................................ & ERR & -2.14 & ERR & ERR & 3.94 & -.154 & 4.60 & 4.60 & -2.37 & -.539 \\
\hline 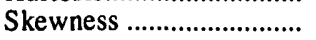 & 1.73 & .486 & -.331 & -.331 & -1.98 & -1.17 & -1.99 & -1.99 & -.645 & 1.01 \\
\hline
\end{tabular}


Appendix 2. Statistical parameters for the data in appendix $1-$ Continued.

\begin{tabular}{|c|c|c|c|c|c|c|c|c|c|c|}
\hline & Sr HP & Sr All & Y HP & Y All & $\mathrm{Zr} \mathrm{HP}$ & Zr All & $\mathrm{Nb} \mathrm{HP}$ & $\mathrm{Nb}$ All & Mo HP & Mo All \\
\hline \multicolumn{11}{|l|}{ UF PC-1 } \\
\hline 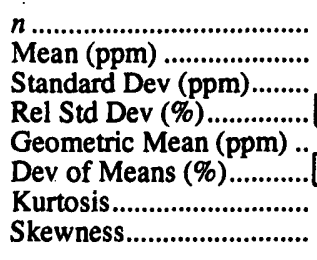 & $\begin{array}{l}12 \\
57 \\
7.6 \\
13.4 \\
56 \\
1.13 \\
10.8 \\
-3.21\end{array}$ & $\begin{array}{l}18 \\
59 \\
7.0 \\
11.9 \\
58 \\
.90 \\
11.8 \\
-3.08\end{array}$ & $\begin{array}{l}9 \\
9 \\
1.0 \\
11.2 \\
9 \\
.56 \\
.0992 \\
.146\end{array}$ & $\begin{array}{l}12 \\
8 \\
2.3 \\
28.7 \\
8 \\
5.38 \\
.761 \\
-1.11\end{array}$ & $\begin{array}{l}6 \\
26 \\
1.7 \\
6.67 \\
26 \\
.19 \\
-2.46 \\
.0672\end{array}$ & $\begin{array}{l}15 \\
24 \\
7.8 \\
32.8 \\
22 \\
7.22 \\
.395 \\
-.708\end{array}$ & $\begin{array}{l}6 \\
2.5 \\
.21 \\
8.61 \\
2.5 \\
.30 \\
-2.15 \\
-.232\end{array}$ & $\begin{array}{l}9 \\
2.2 \\
.49 \\
22.2 \\
2.1 \\
2.61 \\
-.202 \\
-.878\end{array}$ & $\begin{array}{c}3 \\
2.5 \\
.39 \\
15.6 \\
2.5 \\
.77 \\
\text { ERR } \\
1.73\end{array}$ & $\begin{array}{c}6 \\
2.0 \\
.62 \\
30.8 \\
1.9 \\
4.01 \\
-.664 \\
.558\end{array}$ \\
\hline 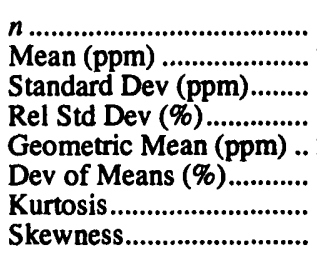 & $\begin{array}{c}9 \\
257 \\
6.6 \\
2.55 \\
257 \\
.03 \\
-.362 \\
-.848\end{array}$ & $\begin{array}{c}18 \\
240 \\
49 \\
20.5 \\
230 \\
2.42 \\
-.106 \\
-1.07\end{array}$ & $\begin{array}{l}9 \\
3.7 \\
.13 \\
3.65 \\
3.7 \\
.06 \\
2.11 \\
-.152\end{array}$ & $\begin{array}{l}12 \\
3.5 \\
.40 \\
11.4 \\
3.5 \\
.71 \\
5.55 \\
-2.25\end{array}$ & $\begin{array}{c}6 \\
21 \\
2.1 \\
10.3 \\
21 \\
.45 \\
-1.97 \\
-.179\end{array}$ & $\begin{array}{l}12 \\
19 \\
3.1 \\
16.1 \\
19 \\
1.38 \\
1.65 \\
-1.05\end{array}$ & $\begin{array}{c}6 \\
1.2 \\
.25 \\
20.5 \\
1.2 \\
1.87 \\
-1.1 \\
-.453\end{array}$ & $\begin{array}{l}9 \\
1.3 \\
.28 \\
21.7 \\
1.3 \\
2.13 \\
.745 \\
.339\end{array}$ & $\begin{array}{l}3 \\
.52 \\
.021 \\
4.15 \\
.52 \\
.06 \\
\text { ERR } \\
-.611\end{array}$ & $\begin{array}{c}6 \\
.59 \\
.087 \\
14.7 \\
.59 \\
.91 \\
-2.58 \\
.0571\end{array}$ \\
\hline \multicolumn{11}{|c|}{ PITT PC-4 } \\
\hline 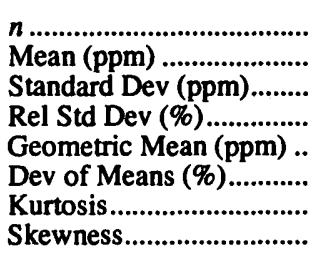 & $\begin{array}{l}12 \\
64 \\
3.0 \\
4.73 \\
64 \\
.10 \\
1.44 \\
.0462\end{array}$ & $\begin{array}{l}18 \\
70 \\
11 \\
16.1 \\
68 \\
1.07 \\
3.43 \\
1.95\end{array}$ & $\begin{array}{c}9 \\
4.4 \\
.45 \\
10.3 \\
4.3 \\
.45 \\
-.0734 \\
1.11\end{array}$ & $\begin{array}{c}12 \\
4.0 \\
.72 \\
17.9 \\
4.0 \\
1.56 \\
-.295 \\
-.214\end{array}$ & $\begin{array}{c}6 \\
19 \\
1.5 \\
7.65 \\
19 \\
.24 \\
-2.45 \\
.344\end{array}$ & $\begin{array}{l}15 \\
18 \\
4.5 \\
24.8 \\
18 \\
3.16 \\
.802 \\
.0791\end{array}$ & $\begin{array}{l}6 \\
1.8 \\
.13 \\
7.45 \\
1.8 \\
.23 \\
1.3 \\
.440\end{array}$ & $\begin{array}{l}9 \\
1.8 \\
.14 \\
7.63 \\
1.8 \\
.25 \\
-.370 \\
.631\end{array}$ & $\begin{array}{l}3 \\
.74 \\
.033 \\
4.51 \\
.74 \\
.07 \\
\text { ERR } \\
1.12\end{array}$ & $\begin{array}{l}6 \\
.77 \\
.066 \\
8.69 \\
.77 \\
.31 \\
-1.75 \\
.540\end{array}$ \\
\hline \multicolumn{11}{|c|}{ POC PC-5 } \\
\hline \multicolumn{11}{|c|}{ UT PC-6 } \\
\hline 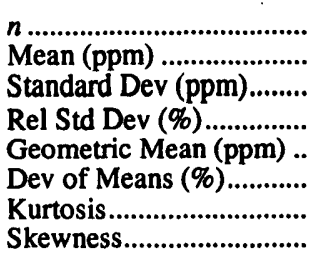 & $\begin{array}{l}8 \\
64 \\
5.2 \\
8.16 \\
63 \\
.28 \\
-1.87 \\
.718\end{array}$ & $\begin{array}{l}14 \\
70 \\
12 \\
17.2 \\
70 \\
1.26 \\
.249 \\
1.21\end{array}$ & $\begin{array}{l}5 \\
2.0 \\
.12 \\
6.12 \\
2.0 \\
.16 \\
2.00 \\
-1.36\end{array}$ & $\begin{array}{l}8 \\
1.9 \\
.17 \\
8.67 \\
1.9 \\
.35 \\
.994 \\
-1.01\end{array}$ & $\begin{array}{c}3 \\
17.3 \\
.58 \\
3.33 \\
17.3 \\
.04 \\
\text { ERR } \\
1.73\end{array}$ & $\begin{array}{l}9 \\
15 \\
3.4 \\
21.9 \\
15 \\
2.48 \\
-.0765 \\
-.756\end{array}$ & $\begin{array}{c}3 \\
.57 \\
.070 \\
11.8 \\
.56 \\
.50 \\
\text { ERR } \\
1.1\end{array}$ & $\begin{array}{c}6 \\
.54 \\
.062 \\
11.6 \\
.53 \\
.52 \\
1.54 \\
.837\end{array}$ & $\begin{array}{c}3 \\
.42 \\
.023 \\
5.34 \\
.42 \\
.10 \\
\text { ERR } \\
1.65\end{array}$ & $\begin{array}{c}6 \\
.45 \\
.063 \\
13.9 \\
.45 \\
.79 \\
-1.11 \\
.760\end{array}$ \\
\hline \multicolumn{11}{|c|}{ WV PC-7 } \\
\hline 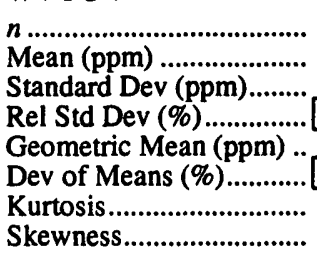 & $\begin{array}{r}12 \\
60 \\
11 \\
17.5 \\
61 \\
1.41 \\
-.805 \\
.354\end{array}$ & $\begin{array}{l}18 \\
70 \\
13 \\
18.2 \\
70 \\
1.74 \\
-1.14 \\
.042\end{array}$ & $\begin{array}{c}6 \\
11.7 \\
.82 \\
7.00 \\
11.6 \\
.20 \\
-.300 \\
.857\end{array}$ & $\begin{array}{c}15 \\
14 \\
4.9 \\
34.0 \\
14 \\
5.52 \\
-1.33 \\
.454\end{array}$ & $\begin{array}{l}6 \\
75 \\
6.7 \\
8.91 \\
75 \\
.34 \\
-2.08 \\
-.488\end{array}$ & $\begin{array}{l}12 \\
70 \\
26 \\
37.7 \\
70 \\
8.60 \\
-.563 \\
-.527\end{array}$ & $\begin{array}{c}6 \\
7 \\
1.3 \\
18.3 \\
7 \\
1.43 \\
-2.05 \\
.054\end{array}$ & $\begin{array}{l}11 \\
7 \\
6.0 \\
82.1 \\
7 \\
11.46 \\
-.303 \\
.611\end{array}$ & $\begin{array}{l}3 \\
1.27 \\
.049 \\
3.83 \\
1.27 \\
.05 \\
\text { ERR } \\
-.586\end{array}$ & $\begin{array}{c}6 \\
.61 \\
.21 \\
35.6 \\
.58 \\
5.74 \\
-3.2 \\
.003\end{array}$ \\
\hline \multicolumn{11}{|c|}{ ND PC-8 } \\
\hline 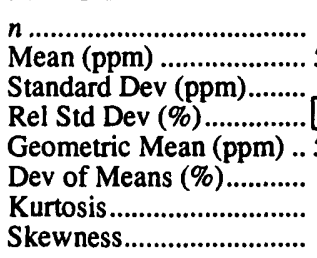 & $\begin{array}{c}12 \\
560 \\
65 \\
11.6 \\
560 \\
.61 \\
-2.04 \\
.239\end{array}$ & $\begin{array}{l}18 \\
600 \\
100 \\
16.7 \\
600 \\
1.30 \\
-.458 \\
.641\end{array}$ & $\begin{array}{c}5 \\
2.1 \\
.22 \\
10.4 \\
2.1 \\
.45 \\
-2.37 \\
-.559\end{array}$ & $\begin{array}{l}8 \\
2.2 \\
.26 \\
11.7 \\
2.2 \\
.62 \\
-.130 \\
-.380\end{array}$ & $\begin{array}{l}6 \\
9 \\
3.4 \\
38.3 \\
8 \\
7.14 \\
-2.21 \\
-.115\end{array}$ & $\begin{array}{l}12 \\
12 \\
4.8 \\
39.1 \\
11 \\
8.59 \\
-.527 \\
.0785\end{array}$ & $\begin{array}{l}3 \\
.79 \\
.050 \\
6.34 \\
.79 \\
.14 \\
\text { ERR } \\
-.59\end{array}$ & $\begin{array}{c}6 \\
.7 \\
.12 \\
18.2 \\
.7 \\
1.44 \\
-1.40 \\
-.199\end{array}$ & $\begin{array}{c}3 \\
.41 \\
.024 \\
5.83 \\
.41 \\
.11 \\
\text { ERR } \\
-.609\end{array}$ & $\begin{array}{c}6 \\
.6 \\
.22 \\
35.5 \\
.6 \\
5.73 \\
-3.21 \\
.0037\end{array}$ \\
\hline
\end{tabular}


Appendix 2. Statistical parameters for the data in appendix 1-Continued.

\begin{tabular}{|c|c|c|c|c|c|c|c|c|}
\hline Ag HP & Ag All & Cd HP & Cd All & Sn HP & Sn All & Sb HP & Sb All & Cs HP \\
\hline \multicolumn{9}{|l|}{ UF PC-1 } \\
\hline \begin{tabular}{lc|} 
\\
Mean (ppm) ..................
\end{tabular} & $\begin{array}{l}6 \\
.3 \\
.17 \\
50.2 \\
.3 \\
10.22 \\
.687 \\
1.11\end{array}$ & 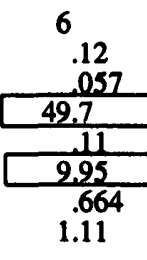 & $\begin{array}{l}6 \\
.12 \\
.057 \\
49.7 \\
.11 \\
9.95 \\
.664 \\
1.11\end{array}$ & $\begin{array}{l}3 \\
.95 \\
0 \\
0 \\
.95 \\
0 \\
\text { ERR } \\
\text { ERR }\end{array}$ & $\begin{array}{l}6 \\
1.3 \\
.39 \\
30.5 \\
1.3 \\
4.09 \\
-3.10 \\
.071\end{array}$ & $\begin{array}{l}6 \\
.51 \\
.034 \\
6.64 \\
.51 \\
.19 \\
.364 \\
-.156\end{array}$ & $\begin{array}{l}6 \\
.51 \\
.034 \\
6.64 \\
.51 \\
.19 \\
.364 \\
-.156\end{array}$ & $\begin{array}{l}6 \\
1.7 \\
.20 \\
12.0 \\
1.7 \\
.61 \\
-3.16 \\
-.063\end{array}$ \\
\hline \multicolumn{9}{|l|}{ WY PC-2 } \\
\hline 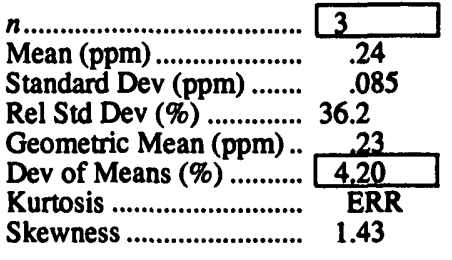 & $\begin{array}{l}6 \\
.2 \\
.11 \\
70.6 \\
.1 \\
23.26 \\
.353 \\
1.03\end{array}$ & 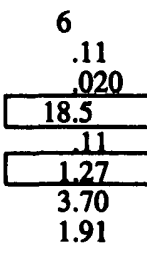 & $\begin{array}{l}6 \\
.11 \\
.020 \\
18.5 \\
.11 \\
1.27 \\
3.70 \\
1.91\end{array}$ & $\begin{array}{l}3 \\
.323 \\
0 \\
0 \\
.323 \\
0 \\
\text { ERR } \\
\text { ERR }\end{array}$ & $\begin{array}{c}6 \\
.6 \\
.36 \\
58.9 \\
.5 \\
13.95 \\
.201 \\
1.17\end{array}$ & $\begin{array}{c}6 \\
.18 \\
.021 \\
11.6 \\
.18 \\
.58 \\
-1.62 \\
-.397\end{array}$ & $\begin{array}{l}6 \\
.18 \\
.021 \\
11.6 \\
.18 \\
.00579 \\
-1.62 \\
-.397\end{array}$ & $\begin{array}{c}6 \\
.195 \\
.010 \\
4.86 \\
.195 \\
.10 \\
-1.22 \\
.198\end{array}$ \\
\hline \multicolumn{9}{|l|}{ IL PC-3 } \\
\hline 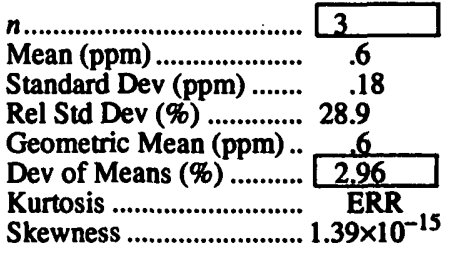 & $\begin{array}{l}6 \\
.5 \\
.18 \\
36.5 \\
.5 \\
5.19 \\
.333 \\
1.14\end{array}$ & $\begin{array}{c}6 \\
.7 \\
19.4 \\
19.4 \\
1.45 \\
1.66 \\
1.36\end{array}$ & $\begin{array}{c}6 \\
.7 \\
.14 \\
19.4 \\
.7 \\
1.45 \\
1.66 \\
1.36\end{array}$ & $\begin{array}{c}3 \\
.71 \\
.094 \\
13.3 \\
.70 \\
.06 \\
\text { ERR } \\
1.73\end{array}$ & $\begin{array}{c}6 \\
2 \\
1.1 \\
67.7 \\
1 \\
22.21 \\
-.966 \\
.809\end{array}$ & $\begin{array}{l}6 \\
.84 \\
.062 \\
7.45 \\
.83 \\
.24 \\
1.49 \\
-.882\end{array}$ & $\begin{array}{l}6 \\
.84 \\
.062 \\
7.45 \\
.83 \\
.24 \\
1.49 \\
-.882\end{array}$ & $\begin{array}{c}6 \\
1.1 \\
.29 \\
25.3 \\
1.1 \\
2.82 \\
-3.17 \\
.019\end{array}$ \\
\hline \multicolumn{9}{|l|}{ PITT PC-4 } \\
\hline 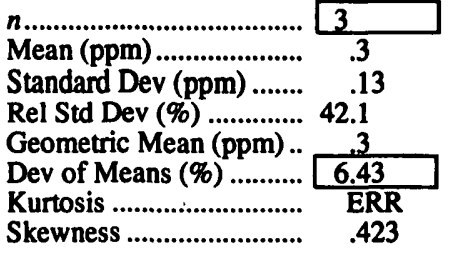 & $\begin{array}{c}6 \\
.2 \\
.14 \\
73.3 \\
.2 \\
23.82 \\
.213 \\
1.14\end{array}$ & \begin{tabular}{|c|c|}
6 \\
.08 \\
.028 \\
34.3 \\
0.08 \\
4.83 \\
$\begin{array}{r}-.779 \\
.738\end{array}$
\end{tabular} & $\begin{array}{c}6 \\
.08 \\
.028 \\
34.3 \\
.08 \\
4.83 \\
-.779 \\
.738\end{array}$ & $\begin{array}{l}3 \\
.552 \\
.0053 \\
.93 \\
.573 \\
0 \\
\text { ERR } \\
1.73\end{array}$ & $\begin{array}{c}6 \\
.9 \\
.46 \\
50.6 \\
.8 \\
10.7 \\
.120 \\
.954\end{array}$ & $\begin{array}{c}6 \\
.22 \\
.022 \\
10.0 \\
.22 \\
.43 \\
-.890 \\
-.340\end{array}$ & $\begin{array}{l}6 \\
.22 \\
.022 \\
10.0 \\
.22 \\
.43 \\
-.890 \\
-.340\end{array}$ & $\begin{array}{c}6 \\
.75 \\
.061 \\
8.16 \\
.75 \\
.28 \\
-2.24 \\
-.432\end{array}$ \\
\hline \multicolumn{9}{|l|}{ POC PC-5 } \\
\hline 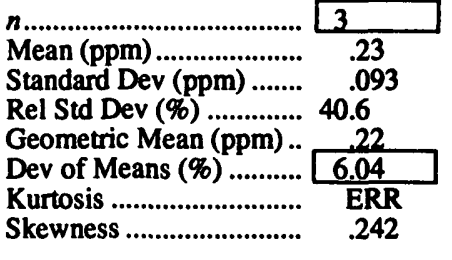 & $\begin{array}{l}6 \\
.16 \\
.090 \\
55.6 \\
.15 \\
12.2 \\
.760 \\
1.33\end{array}$ & $\begin{array}{c}5 \\
.08 \\
.014 \\
19.0 \\
.074 \\
1.61 \\
1.119 \\
-.968\end{array}$ & $\begin{array}{l}6 \\
.07 \\
.02 \\
30.9 \\
.07 \\
5.12 \\
-.088 \\
-.920\end{array}$ & $\begin{array}{l}3 \\
.371 \\
0 \\
0 \\
.371 \\
0 \\
\text { ERR } \\
\text { ERR }\end{array}$ & $\begin{array}{c}6 \\
40 \\
57 \\
159 \\
5 \\
700 \\
4.29 \\
2.02\end{array}$ & $\begin{array}{c}6 \\
.4 \\
.14 \\
33.8 \\
4 \\
4.81 \\
-1.69 \\
.508\end{array}$ & $\begin{array}{c}6 \\
.4 \\
.14 \\
33.8 \\
.4 \\
4.81 \\
-1.69 \\
.508\end{array}$ & $\begin{array}{l}6 \\
.24 \\
.024 \\
9.91 \\
.24 \\
.40 \\
.192 \\
.876\end{array}$ \\
\hline \multicolumn{9}{|l|}{ UT PC-6 } \\
\hline 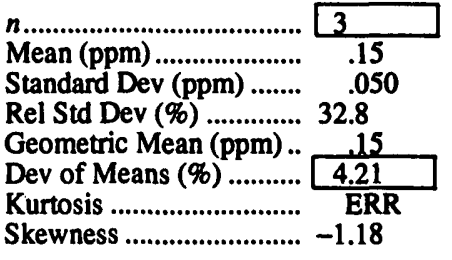 & $\begin{array}{c}6 \\
.3 \\
.18 \\
58.7 \\
.3 \\
19.1 \\
-2.11 \\
.155\end{array}$ & $\begin{array}{c}5 \\
.07 \\
.012 \\
17.5 \\
.07 \\
1.19 \\
-1.52 \\
.824\end{array}$ & $\begin{array}{c}5 \\
.07 \\
.012 \\
17.5 \\
.07 \\
1.19 \\
-1.52 \\
.824\end{array}$ & $\begin{array}{r}3 \\
.17 \\
.03 \\
15.8 \\
.17 \\
.89 \\
\text { ERR } \\
-1.73\end{array}$ & $\begin{array}{c}6 \\
.3 \\
.12 \\
45.8 \\
.2 \\
9.21 \\
-1.99 \\
.471\end{array}$ & 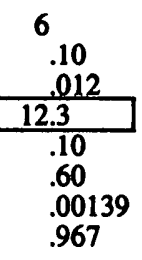 & $\begin{array}{l}6 \\
.10 \\
.012 \\
12.3 \\
.10 \\
.60 \\
.00139 \\
.967\end{array}$ & $\begin{array}{c}6 \\
.14 \\
.012 \\
8.68 \\
.14 \\
.32 \\
-1.55 \\
-.706\end{array}$ \\
\hline \multicolumn{9}{|l|}{ WV PC-7 } \\
\hline 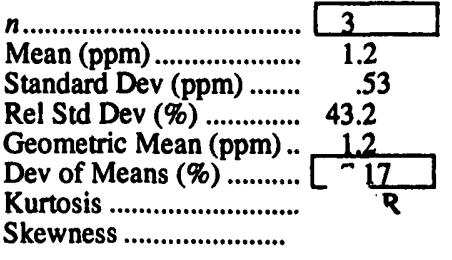 & $\begin{array}{l}6 \\
.8 \\
.55 \\
64.6 \\
.7 \\
16.9 \\
.243 \\
1.21\end{array}$ & $\begin{array}{c}6 \\
.07 \\
.016 \\
24.9 \\
.07 \\
3.23 \\
.971 \\
-1.23\end{array}$ & $\begin{array}{c}6 \\
.07 \\
.016 \\
24.9 \\
.07 \\
3.23 \\
-.971 \\
-1.23\end{array}$ & $\begin{array}{l}3 \\
1.75 \\
0 \\
0 \\
1.75 \\
0 \\
\text { ERR } \\
\text { ERR }\end{array}$ & $\begin{array}{c}6 \\
1.8 \\
.18 \\
10.1 \\
1.8 \\
.41 \\
.666 \\
.961\end{array}$ & $\begin{array}{l}6 \\
.54 \\
.041 \\
7.65 \\
.54 \\
.23 \\
3.66 \\
1.75\end{array}$ & $\begin{array}{l}6 \\
.54 \\
.041 \\
7.65 \\
.54 \\
.23 \\
3.66 \\
1.75\end{array}$ & $\begin{array}{c}6 \\
2.1 \\
.27 \\
12.9 \\
2.1 \\
.63 \\
-3.30 \\
-.011\end{array}$ \\
\hline \multicolumn{9}{|l|}{ ND PC-8 } \\
\hline 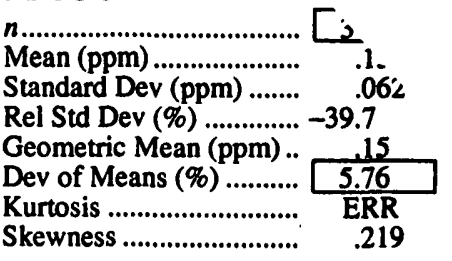 & ${ }^{3}{ }_{52}$ & $\begin{array}{c}6 \\
.043 \\
.0072 \\
18 \\
.041 \\
1.58 \\
1.52 \\
-1.45\end{array}$ & $\begin{array}{c}6 \\
.043 \\
.0072 \\
18 \\
.041 \\
1.58 \\
1.52 \\
-1.45\end{array}$ & $\begin{array}{c}3 \\
.4 \\
.16 \\
43.3 \\
.4 \\
5.84 \\
\text { ERR } \\
1.73\end{array}$ & $\begin{array}{c}4 \\
.6 \\
.45 \\
76.2 \\
.5 \\
21.9 \\
1.96 \\
1.53\end{array}$ & $\begin{array}{l}5 \\
.15 \\
.010 \\
6.80 \\
.15 \\
.19 \\
-.906 \\
-.516\end{array}$ & $\begin{array}{c}6 \\
.15 \\
.020 \\
12.7 \\
.15 \\
.64 \\
2.45 \\
1.33\end{array}$ & $\begin{array}{c}6 \\
.09 \\
.012 \\
13.0 \\
.09 \\
.77 \\
1.86 \\
-1.34\end{array}$ \\
\hline
\end{tabular}


Appendix 2. Statistical parameters for the data in appendix $1-$ Continued.

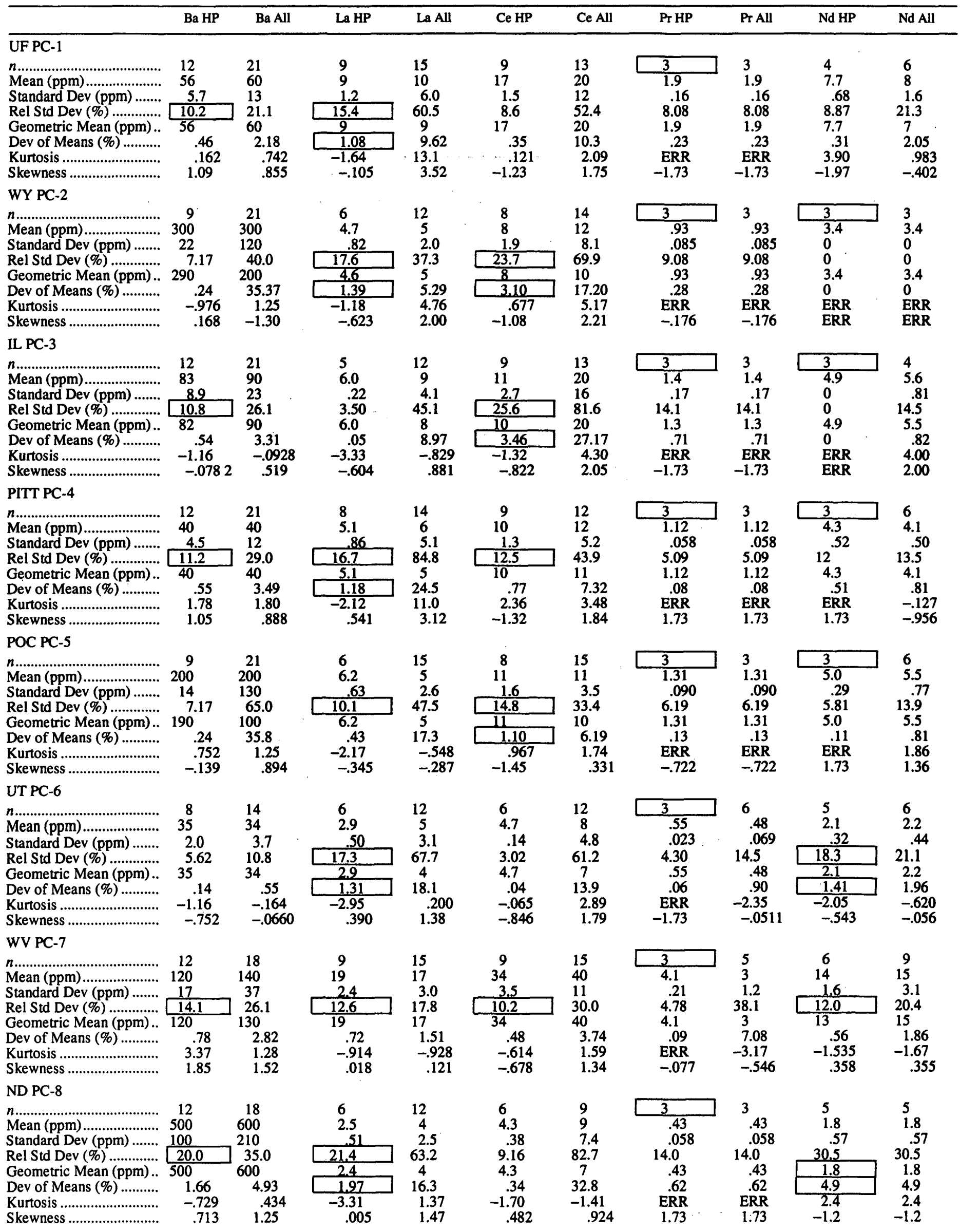


Appendix 2. Statistical parameters for the data in appendix 1-Continued.

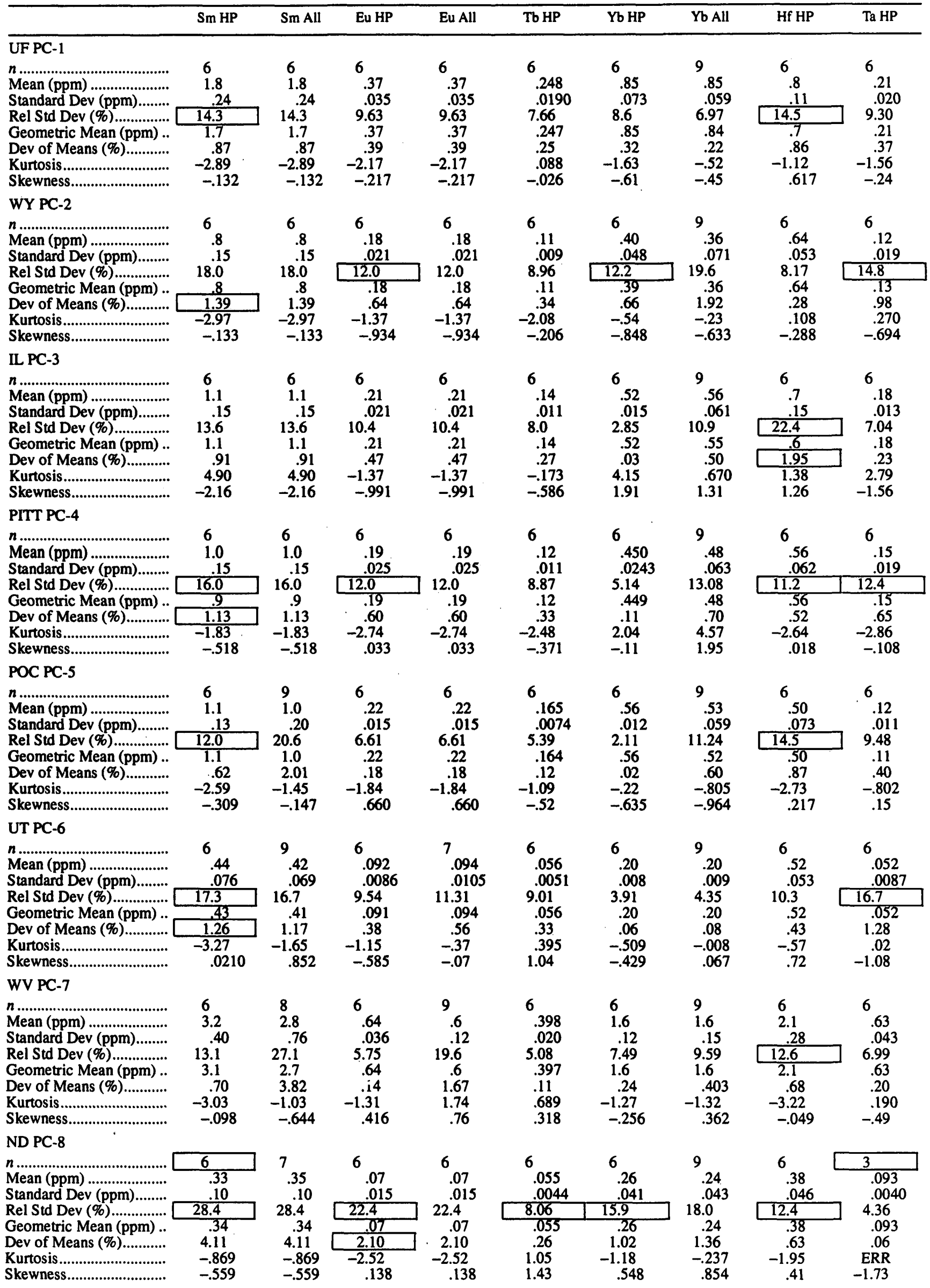


Appendix 2. Statistical parameters for the data in appendix $1-$ Continued.

\begin{tabular}{|c|c|c|c|c|c|c|c|c|c|}
\hline & W HP & W All & $\mathrm{Pb} \mathrm{HP}$ & $\mathbf{P b}$ All & Bi HP & Bi All & Th HP & Th All & U HP \\
\hline \multicolumn{10}{|l|}{ UF PC-1 } \\
\hline 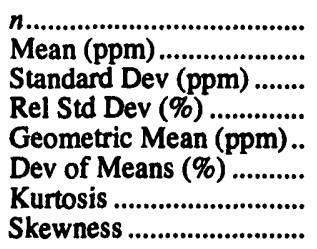 & $\begin{array}{l}6 \\
1.2 \\
.13 \\
11.0 \\
1.1 \\
.48 \\
-1.56 \\
.56\end{array}$ & $\begin{array}{c}6 \\
1.2 \\
.13 \\
11.0 \\
1.1 \\
.48 \\
-1.56 \\
.56\end{array}$ & $\begin{array}{l}6 \\
7.5 \\
.33 \\
4.39 \\
7.5 \\
.08 \\
1.34 \\
-1.22\end{array}$ & $\begin{array}{l}12 \\
8 \\
1.5 \\
18.4 \\
8 \\
1.54 \\
-.902 \\
.469\end{array}$ & $\begin{array}{c}3 \\
.117 \\
.0058 \\
4.95 \\
.117 \\
.08 \\
\text { ERR } \\
-1.73\end{array}$ & $\begin{array}{c}3 \\
.117 \\
.0058 \\
4.95 \\
.117 \\
.08 \\
\text { ERR } \\
-1.73\end{array}$ & $\begin{array}{l}6 \\
2.5 \\
.48 \\
19.2 \\
2.5 \\
1.96 \\
4.82 \\
-2.12\end{array}$ & $\begin{array}{c}6 \\
2.5 \\
.48 \\
19.2 \\
2.5 \\
1.96 \\
4.82 \\
-2.12\end{array}$ & $\begin{array}{l}6 \\
1.0 \\
.18 \\
18.4 \\
1.0 \\
1.55 \\
-2.91 \\
.102\end{array}$ \\
\hline \multicolumn{10}{|l|}{ WY PC-2 } \\
\hline 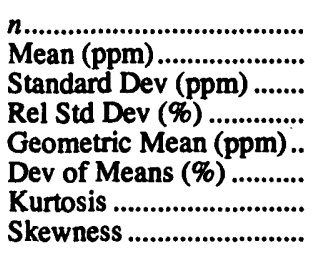 & $\begin{array}{c}6 \\
.42 \\
.055 \\
12.7 \\
.42 \\
.66 \\
-1.68 \\
.535\end{array}$ & $\begin{array}{c}6 \\
.42 \\
.055 \\
12.7 \\
.42 \\
.66 \\
-1.68 \\
.535\end{array}$ & $\begin{array}{c}6 \\
2.3 \\
.75 \\
33.2 \\
2.2 \\
4.72 \\
-3.01 \\
.122\end{array}$ & $\begin{array}{c}9 \\
2.6 \\
.90 \\
34.3 \\
2.5 \\
5.84 \\
-1.03 \\
.096\end{array}$ & $\begin{array}{c}3 \\
.053 \\
.0034 \\
6.45 \\
.053 \\
.14 \\
\text { ERR } \\
-1.73\end{array}$ & $\begin{array}{c}3 \\
.053 \\
.0034 \\
6.45 \\
.053 \\
.14 \\
\text { ERR } \\
-1.73\end{array}$ & $\begin{array}{c}6 \\
1.6 \\
.25 \\
16.2 \\
1.6 \\
.95 \\
2.21 \\
1.17\end{array}$ & $\begin{array}{c}6 \\
1.6 \\
.25 \\
16.2 \\
1.6 \\
.95 \\
2.21 \\
1.17\end{array}$ & $\begin{array}{l}6 \\
.58 \\
.054 \\
9.35 \\
.58 \\
.35 \\
-2.66 \\
-4.6 \times 10^{-15}\end{array}$ \\
\hline \multicolumn{10}{|l|}{ IL PC-3 } \\
\hline 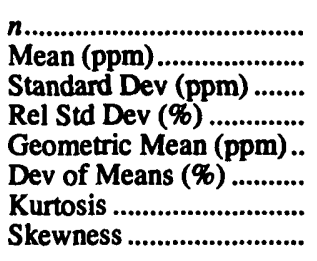 & $\begin{array}{l}.6 \\
1.73 \\
.256 \\
14.4 \\
1.69 \\
.82 \\
-.637 \\
.929\end{array}$ & $\begin{array}{c}6 \\
1.73 \\
.256 \\
14.4 \\
1.69 \\
.82 \\
-.637 \\
.929\end{array}$ & $\begin{array}{c}6 \\
7 \\
1.1 \\
15.6 \\
7 \\
1.04 \\
-2.91 \\
-.019\end{array}$ & $\begin{array}{l}12 \\
9 \\
3.0 \\
32.6 \\
9 \\
4.59 \\
-.637 \\
.885\end{array}$ & $\begin{array}{l}2 \\
.088 \\
.0011 \\
1.61 \\
.088 \\
.01 \\
\text { ERR } \\
\text { ERR }\end{array}$ & $\begin{array}{l}2 \\
.088 \\
.0011 \\
1.61 \\
.088 \\
.01 \\
\text { ERR } \\
\text { ERR }\end{array}$ & $\begin{array}{l}6 \\
2.1 \\
.19 \\
9.28 \\
2.1 \\
.33 \\
3.31 \\
1.81\end{array}$ & $\begin{array}{l}6 \\
2.1 \\
.19 \\
9.28 \\
2.1 \\
.33 \\
3.31 \\
1.81\end{array}$ & $\begin{array}{l}6 \\
5 \\
1.2 \\
23.1 \\
5 \\
2.27 \\
-2.70 \\
.164\end{array}$ \\
\hline \multicolumn{10}{|l|}{ PITT PC-4 } \\
\hline 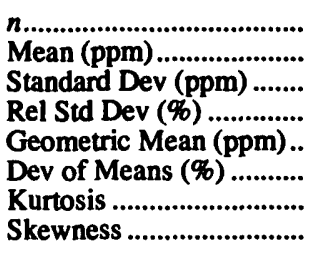 & $\begin{array}{l}6 \\
.82 \\
.049 \\
5.82 \\
.82 \\
.15 \\
-.80 \\
.43\end{array}$ & $\begin{array}{l}6 \\
.82 \\
.049 \\
5.82 \\
.82 \\
.15 \\
-.80 \\
.43\end{array}$ & $\begin{array}{c}6 \\
3.4 \\
.50 \\
15.0 \\
3.3 \\
.94 \\
-3.14 \\
.066\end{array}$ & $\begin{array}{l}12 \\
5 \\
1.8 \\
40.1 \\
4 \\
6.86 \\
-.680 \\
.962\end{array}$ & $\begin{array}{c}3 \\
.117 \\
.0053 \\
4.95 \\
.116 \\
.08 \\
\text { ERR } \\
-1.73\end{array}$ & \begin{tabular}{c}
5 \\
.8 \\
118.91 \\
\multicolumn{1}{c}{.3} \\
125 \\
-2.36 \\
.776
\end{tabular} & $\begin{array}{l}6 \\
1.5 \\
.15 \\
9.52 \\
1.5 \\
.36 \\
1.66 \\
1.34\end{array}$ & $\begin{array}{l}6 \\
1.5 \\
.15 \\
9.52 \\
1.5 \\
.36 \\
1.66 \\
1.34\end{array}$ & $\begin{array}{c}6 \\
.5 \\
.10 \\
21.4 \\
.5 \\
2.02 \\
-2.37 \\
-.228\end{array}$ \\
\hline \multicolumn{10}{|l|}{ POC PC-5 } \\
\hline 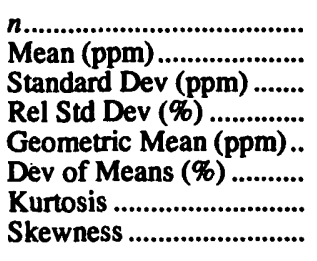 & $\begin{array}{l}\frac{6}{1.0} \\
.16 \\
16.7 \\
96 \\
1.17 \\
-1.17 \\
.281\end{array}$ & $\begin{array}{c}6 \\
1.0 \\
.16 \\
16.7 \\
.96 \\
1.17 \\
-1.17 \\
.281\end{array}$ & $\begin{array}{l}6 \\
2.1 \\
.40 \\
19.3 \\
2.0 \\
1.68 \\
-2.96 \\
-.064\end{array}$ & $\begin{array}{c}12 \\
5 \\
3.9 \\
78.5 \\
4 \\
29.52 \\
-.0035 \\
1.17\end{array}$ & $\begin{array}{c}3 \\
.051 \\
.0022 \\
4.06 \\
.051 \\
.06 \\
\text { ERR } \\
-1.29\end{array}$ & $\begin{array}{c}3 \\
.051 \\
.0022 \\
4.06 \\
.051 \\
.06 \\
\text { ERR } \\
-1.29\end{array}$ & $\begin{array}{l}6 \\
1.16 \\
.043 \\
3.71 \\
1.15 \\
.06 \\
-1.48 \\
-.809\end{array}$ & $\begin{array}{l}6 \\
1.16 \\
.043 \\
3.71 \\
1.15 \\
.06 \\
-1.48 \\
-.809\end{array}$ & \begin{tabular}{|c|}
\multicolumn{6}{c}{6} \\
.57 \\
.071 \\
12.5 \\
.57 \\
.68 \\
-1.81 \\
-.400
\end{tabular} \\
\hline \multicolumn{10}{|l|}{ UT PC-6 } \\
\hline $\begin{array}{l}\text { Mean (ppm) .................... } \\
\text { Standard Dev (ppm) ........ } \\
\text { Rel Std Dev (\%) ............ } \\
\text { Geometric Mean (ppm).. } \\
\text { Dev of Means (\%) ........... } \\
\text { Kurtosis ......................... } \\
\text { Skewness ...................... } \\
\text { WV PC-7 }\end{array}$ & $\begin{array}{c}6 \\
.45 \\
.062 \\
13.53 \\
.450 \\
.78 \\
-2.85 \\
-.182\end{array}$ & $\begin{array}{c}6 \\
.45 \\
.062 \\
13.53 \\
.450 \\
.78 \\
-2.85 \\
-.182\end{array}$ & $\begin{array}{l}5 \\
1.52 \\
.084 \\
5.50 \\
1.52 \\
.12 \\
-.612 \\
-.512\end{array}$ & $\begin{array}{c}8 \\
1.7 \\
.25 \\
15.0 \\
1.7 \\
.94 \\
-.333 \\
.968\end{array}$ & $\begin{array}{l}3 \\
.035 \\
.0007 \\
1.63 \\
.035 \\
.01 \\
\text { ERR } \\
1.73\end{array}$ & $\begin{array}{l}3 \\
.035 \\
.0007 \\
1.63 \\
.035 \\
.01 \\
\text { ERR } \\
1.73\end{array}$ & $\begin{array}{l}6 \\
.60 \\
.025 \\
4.13 \\
.60 \\
.07 \\
3.37 \\
-1.70\end{array}$ & $\begin{array}{c}6 \\
.60 \\
.025 \\
4.13 \\
.60 \\
.07 \\
3.37 \\
-1.70\end{array}$ & $\begin{array}{l}6 \\
.79 \\
.056 \\
7.08 \\
.78 \\
.21 \\
-.674 \\
-.502\end{array}$ \\
\hline 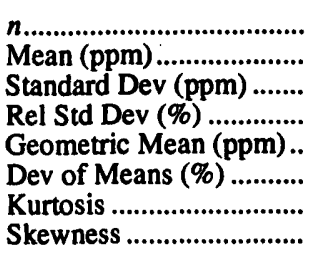 & 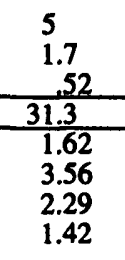 & $\begin{array}{c}6 \\
4 \\
6.5 \\
151.0 \\
2 \\
80.2 \\
5.89 \\
2.42\end{array}$ & $\begin{array}{c}6 \\
12.1 \\
0 \\
0 \\
12.1 \\
0 \\
\text { ERR } \\
\text { ERR }\end{array}$ & $\begin{array}{c}9 \\
13 \\
2.2 \\
16.4 \\
13 \\
1.06 \\
1.94 \\
1.72\end{array}$ & $\begin{array}{l}3 \\
.23 \\
0 \\
0 \\
.23 \\
0 \\
\text { ERR } \\
\text { ERR }\end{array}$ & $\begin{array}{l}3 \\
.23 \\
0 \\
0 \\
.23 \\
0 \\
\text { ERR } \\
\text { ERR }\end{array}$ & $\begin{array}{l}6 \\
6.4 \\
.15 \\
2.33 \\
6.4 \\
.02 \\
-1.33 \\
-.315\end{array}$ & $\begin{array}{l}6 \\
6.4 \\
.15 \\
2.33 \\
6.4 \\
.02 \\
-1.33 \\
-.315\end{array}$ & $\begin{array}{c}6 \\
1.9 \\
.29 \\
15.3 \\
1.9 \\
.98 \\
-3.09 \\
.0423\end{array}$ \\
\hline \multicolumn{10}{|l|}{ ND PC-8 } \\
\hline$n$ & 6 & 6 & 6 & 9 & 0 & 0 & 3 & 6 & 5 \\
\hline 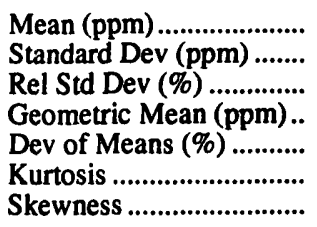 & $\begin{array}{c}. .36 \\
.060 \\
16.8 \\
.35 \\
1.34 \\
2.21 \\
-1.10\end{array}$ & $\begin{array}{c}.36 \\
.060 \\
16.8 \\
.35 \\
1.34 \\
2.21 \\
-1.10\end{array}$ & $\begin{array}{c}1.5 \\
.34 \\
23.0 \\
1.4 \\
2.72 \\
3.07 \\
-1.20\end{array}$ & $\begin{array}{l}1.8 \\
.67 \\
35.8 \\
1.7 \\
6.08 \\
.034 \\
.564\end{array}$ & $\begin{array}{l}\text { ERR } \\
\text { ERR } \\
\text { ERR } \\
\text { ERR } \\
\text { ERR } \\
\text { ERR } \\
\text { ERR }\end{array}$ & $\begin{array}{l}\text { ERR } \\
\text { ERR } \\
\text { ERR } \\
\text { ERR } \\
\text { ERR } \\
\text { ERR } \\
\text { ERR }\end{array}$ & $\begin{array}{c}1.1 \\
.04 \\
3.79 \\
1.1 \\
.05 \\
\text { ERR } \\
.72\end{array}$ & $\begin{array}{r}.88 \\
.21 \\
.18 \\
.23 \\
.86 \\
-2.20 \\
-.228\end{array}$ & $\begin{array}{c}.46 \\
.04 \\
7.87 \\
.46 \\
.24 \\
1.9 \\
.544\end{array}$ \\
\hline
\end{tabular}

